UNIVERSIDADE DE SÃO PAULO

FACULDADE DE FILOSOFIA, LETRAS E CIÊNCIAS HUMANAS

TATIANE MILENE TORRES

POÉTICA DE ALMANAQUE: PAIDÉIA TECEDORA DO SUBLIME

São Paulo

2012 


\section{TATIANE MILENE TORRES}

\section{POÉTICA DE ALMANAQUE: PAIDÉIA TECEDORA DO SUBLIME}

Tese apresentada ao Departamento de Letras Modernas da Faculdade de Filosofia, Letras e Ciências Humanas da Universidade de São Paulo, para obtenção do título de Doutor em Letras.

Área de concentração: Estudos Linguísticos, Literários e Tradutológicos em Francês

Orientador: Prof(a) Dr(a) Maria Cecilia Queiroz de Moraes Pinto 
São Paulo

2012

\section{Sumário}

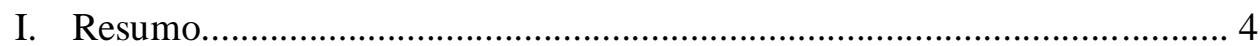

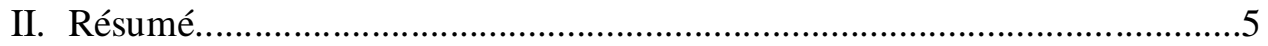

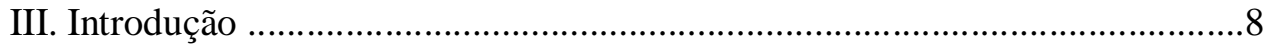

\section{Capítulos}

1. Urbes dos sonhos: quimeras de almanaque 20

2. Ascese à beleza dos deuses: conquista da plenitude 97

3. Elixires para uma longa vida: bálsamos para todos os males 140

4. Fetichização de almanaquias: mercadorias de um microcosmo onírico 179

5. Prognósticos de bien-vivre: a cartomancia de deleites nas mãos do flâneur-poeta 195

6. Domesticação cíclico-poética do tempo: cronos domado pelos calendários 215

Considerações Finais 255

Referências Bibliográficas 257 


\section{Resumo}

O estudo comparativo entre o Almanaque Brasileiro Garnier, publicado entre 1903 e 1914, e o Almanach Hachette, que esteve em circulação entre 1894 e 1980, busca aferir o engendro anual das cidades ideais, Paris e Rio de Janeiro, por meio do ato poético resgatador

do Belo, para tessitura do Sublime, no melhor dos mundos possíveis de almanaque. É a feitura incessante de tal microcosmo místico-poético que permite aos leitores uma vida resguardada das problemáticas modernas, posto que dentro de tal redoma onírica passam por um processo terapêutico de cura dos males contraídos na massa caótica circundante, para então, sãos, poderem enxergar a verdadeira beleza do mundo. É, pois, o papel de tirar as escamas dos olhos, da Paidéia Poética diária, para alcance da acuidade de visão, que possibilita a denúncia do Feio simbolizado pelas mazelas da modernidade, o que permite a edificação de tal empírio terrestre, para a vivência do Tempo Sagrado advindo da nova Criação. Tal resgate do princípio do mundo, pela Poiésis, traduz a verdadeira idade de ouro na chamada Belle Époque brasileira e francesa, onde seus cidadãos vivem um tempo de eterna boa ventura, com toda sorte de abundância e de regozijo, caracterizada pela infinidade de almanaquias para deleite proveniente do Pays de Cocagne e do Eldorado. É a fartura de alimento poético, servido periodicamente na grande mesa da Terra sem Males de almanaque, que age no corpo e no espírito como tônico resgatador da plenitude perdida, simbolizadora da infinitude reconquistada, pela tessitura ininterrupta do Sublime, nas Repúblicas das delícias do Eldorado, não das Américas, mas de todos os continentes que compõem tal sítio maravilhoso. 


\section{Résumé}

L'étude comparatif entre l'Almanaque Brasileiro Garnier, publié entre 1903 et 1914, et l'Almanach Hachette, édité entre 1894 et 1980, cherche corroborer l'engendre anuel des cités idéales, Paris et Rio de Janeiro, par l'acte poétique recupérateur du Beau, pour la tessiture du Sublime, dans le meilleur des mondes possibles. C'est la fabrication incessante de ce microcosme mystique-poétique qui permet aux lecteurs acquerir une vie protégée des problématiques modernes, puisque dans cette cloche en verre onirique ils subissent une thérapeutique des maux contractés dans la foule caotique environnante, puis guéris, puissent voir la vraie beauté du monde. C'est le rôle de tirer les échelles des yeux, de la Paidéia Poétique quotidienne, pour la conquête de l'acuité de vision, qui permet la plainte du Laid symbolisé par les malheurs de la modernité, ce qui permet l'édification de ce paradis terrestre pour l'expérience du Temps Sacré concernant la nouvelle Création. Cette recupération du principe du monde, par la Poiésis, traduit le véritable âge d'or de la soi-disant Belle Époque brésilienne et française, dans laquelle les citoyens vivent un temps d'éternelle bonaventure, avec toute sorte d'abondance et de jouissance, caractérisée par l'infinité d'almanaquias pour leur ravissement à partir du Pays de Cocagne et de l'Eldorado. C'est l'abondance de nourriture poétique, servie sur la grande table de la Terre sans Maux d'almanach, qui agit sur le corps et l'esprit comme tonique regénérateur de la plenitude perdue, laquelle symbolise l'infini récupéré par l'engendrement ininterrompu du Sublime dans les Républiques des délices de l'Eldorado, pas celui des Amériques, mais de tous les continents qui composent ce site merveilleux. 


\section{Agradecimentos}

Aos mestres-imortais, tecedores incansáveis da academia para o melhor dos mundos possíveis.

A minha família, a própria Paidéia para a vida.

Aos amigos, fiandeiros de alegria eterna. 
Ao Divino, Senhor da minha vida e guia dos meus passos. 


\section{Introdução}

Tendo em vista o estudo comparativo entre o Almanaque Brasileiro Garnier, produzido por uma das últimas filiais francesas instituídas no Rio de Janeiro, Livraria Garnier, e o Almanach Hachette, em Paris, pela Librairie Hachette, iniciemos com a menção à pesquisa na Université de Versailles Saint-Quentin-en-Yvelines, no ano de 2008, que enriqueceu sobremaneira o desenvolvimento da tese, onde pude ter acesso ao Centre d'Histoire Culturelle des Sociétés Contemporaines e ao Laboratoire Suds d'Amériques, cujo professor Dr. Jean-Yves Mollier recebeu-me de maneira estimável e possibilitou acesso a vasta bibliografia no tocante à literatura popular francesa. Outra ocasião que contribuiu de maneira significativa para a tessitura do trabalho foi a participação, no ano de 2009, do convênio entre a Universidade de São Paulo e a Université Lumière Lyon 2, o que permitiu recolher material de grande importância pelo contato com professores, que colaboraram para levantamento bibliográfico nas bibliotecas da universidade, tanto no Campus Bernes du Rhône quanto no Campus Portes des Alpes.

Considerando a relevância de tais experiências no âmbito acadêmico francês, seria mister ali retornar para melhor aprofundamento da análise proposta, o que direcionou ao pedido da bolsa Capes para participação do Programa de Doutorado no País com Estágio no Exterior - PDEE, na mesma universidade visitada, Université Lumière Lyon 2. Voltar a tal sítio, em 2010, foi assaz valioso para dar continuidade ao levantamento bibliográfico concernente à literatura popular francesa e às temáticas desenvolvidas no estudo em questão, além de manter contato com o professor Dr. Jorge Santiago, que sugeriu leituras significativas, sobretudo no que diz respeito à temática central do estudo, o Rio de Janeiro, que, por sua vez, é também pesquisada por ele já em alguns trabalhos, como: Rio et la ville clandestine Anthropologie et littérature de Lima Barreto, dentre outros artigos e livros.Conhecer e trocar ideias com a professora Dra. Nadine Decourt, pesquisadora notável no âmbito da literatura popular, especificamente dos contos populares, foi também um tanto quanto importante, posto que sugeriu uma série de leituras e contribuiu com novas e 
relevantes ideias para o aprimoramento do estudo, tanto no que diz respeito ao viés oral como ao sócio-cultural.

Tal período de estágio na França permitiu igualmente a ida à Université de Limoges, o que possibilitou a pesquisa do acervo de sua biblioteca e do Centre de Littératures Populaires et Culture Médiatique, além do contato, por intermédio da professora Dra. Nadine Decourt, com o professor Dr. Jacques Miggozzi, referência no tocante à literatura popular francesa, que enviou informação concernente à publição em tal âmbito e à associação engendrada a partir do Séminaire Internationale "Les Littératures Populaires en France aujourd'hui". Seguidamente, a visita à Université de Brest, ocasião singular para enriquecimento da análise no que concerne aos gêneros populares, onde recolhi material bibliográfico e pude pesquisar no acervo do Centre de Recherche Bretonne et Celtique, o que possibilitou conhecer um pouco da rica literatura oriunda da região da Bretanha.

Tais visitas aos centros de literatura popular direcionam ao fato de que ainda que a origem dos almanaques analisados esteja na produção das grandes livrarias Garnier e Hachette, são herdeiros e reproduzem todo um passado em que os gêneros populares faziam parte da leitura, da oralidade e da socialibilidade do povo em detrimento da literatura "dita culta" das classes letradas. É nesse viés que se discorre sobre a literatura da qual os almanaques fazem parte, a littérature de colportage e a literatura popular brasileira, que foram em sua origem difundidas pelos caixeiros viajantes, ou seja, pessoas que facilitaram o seu acesso, os colporteurs na França e os mascates no Brasil, papel esse que posteriormente as editoras e os livros impressos em série puderam realizar, como as próprias livrarias supracitadas.

É importante salientar que a literatura dita popular é nomeada de tal forma por não ter, até o presente momento, encontrado uma designação apropriada, o que mostra o seu desconhecimento e a sua incompreensão, remetendo ao que Geneviève Bollème elucida em relação a tal dificuldade identitária e a tal falta de apreço:

Car à peine porte-t-elle um nom: on la qualifie de littérature populaire. Nom qui est celui de límpossibilité même de la nommer, littérature du plus grand nombre, nom qui dit qu'elle est mal connue, méconnue, mal aimeé, innommable...(BOLLÈME, 1971,p.8)

É o que atesta um consenso muitas vezes problemático segundo os exegetas, pois ainda hoje, deploravelmente, a literatura popular é recebida com um tom de desvalorização, sendo considerada como paraliteratura, reforçando sempre que possível a leitura dialética ou a ênfase na dicotomia "literatura popular" x "literatura culta", a primeira oriunda de um escalão 
inferior e a segunda advinda das classes letradas. Felizmente, essa concepção equivocada já não é mais sustentada na academia, visto que em todo mundo observa-se um crescente número de pesquisadores e especialistas dos gêneros populares, o que valoriza e faz conhecer o que de mais notável tem o ato criador de um povo e a sua propagação, muitas vezes pelo viés da oralidade, que certifica o quão importante é tal literatura, inscrita e rememorada pelo imaginário coletivo durante anos a fio. Se a perenidade é garantida pela recordação passada de geração a geração, questionando a nomeação "capenga" de tal literatura, isso não permite encobrir sua grandeza, posto que o anonimato ou a não preocupação com a autoria individual, que segundo Bollème (1971, p.21) a caracteriza “... l'auteur est sans propriété sur son texte, on peut dire qu'il s'agit là d'une littérature essentiellement anonyme”, permite justamente a sustentação do imaginário coletivo, repetidor e auxiliar da feitura incessante do canto popular que estetiza o mundo.

Ao analisar o diálogo Brasil-França concernente às literaturas populares de ambos os países, é interessante destacar que a literatura popular do nordeste é herdeira das canções de gesta francesas, o que corrobora tal cotejo, pois ainda que não focado na literatura de cordel, o trabalho desenvolvido faz um paralelo entre os almanaques inseridos, de acordo com sua origem, nas literaturas populares mencionadas. É o que salienta G. Bollème quando coloca a questão das histórias do cordel estar ligadas à lenda de Carlos Magno e dos Doze Pares, "reforçando a hipótese de que a literatura de cordel é o estágio atual da evolução da poesia popular épica, cujos veios mais remotos passam pela 'Chanson de Geste' dos 'trouvères' do norte da França" (Ribeiro, 1986, p.85).

Além da herança da gesta, observa-se que a própria literatura de colportage como um todo, apresenta similitudes com a literatura popular brasileira, tanto no que tange aos ciclos temáticos quanto aos gêneros populares. Nessa perspectiva, vê-se que ambas são representativas de uma literatura de vocação popular, que apresenta desde novelas de cavalaria, livros de piedade, romances, contos de fada, poesia, livros de sonho, almanaques, dentre outros. Em decorrência disso, o historiador francês, Robert Mandrou, aponta uma evidente analogia com o material das edições francesas, por meio da qual sugere uma divisão em conjuntos temáticos, como a mitologia, o maravilhoso pagão e os contos de fadas, os tratados, os calendários e os almanaques, as obras de piedade, a vida dos santos, os romances, os jogos e a educação, etc.

Outra semelhança apontada é a qualidade do material em que essa literatura era impressa, e que no Brasil perdura nos cordéis, pois tanto uma quanto a outra confeccionava 
seus livros em papel módico e os ilustravam com antigas gravuras a partir do relevo em prancha de madeira, ou seja, pelo método da xilogravura. É justamente por isso que na Bibliothèque Bleue, expressão francesa que não designa o sítio onde se conservam obras, mas sim um tipo de coleção de livros populares, cuja modéstia do material, remete ao papel azul que servia para embalar pães doces, o mesmo em que se imprimia tal literatura. $\mathrm{O}$ preço baixo da venda de tais livros, um a dois sols - cinco ou dez centavos, é traduzido pela sua impressão simplória, rústica, mal encadernados e paginados de maneira deficitária, ainda seu tamanho reduzido representava o fato de terem sido, inicialmente, confeccionados para ser transportados em balaios $(14 \mathrm{~cm} \times 7 \mathrm{~cm} \text { a } 21 \times 15 \mathrm{~cm})^{1}$.

É exatamente pela compilação de todos os livros da Bibliothèque Bleue que é feita a tessitura do almanaque, cuja função é informar os leitores em relação a tudo o que existe no mundo, como uma espécie de "brochura mágica", haja vista sua constituição calcada na misticidade, na qual a não-compartimentação dos saberes permite a formação dos leitores para a excelência, tendo em sua característica de literatura de valor módico a garantia de acessibilidade a diferentes classes, sobretudo as modestas que, por sua vez, representam, grosso modo, seu público leitor. Contudo, tal concentração no que tange a sua acessibilidade pelas camadas populares não condiz com a sua não-absorção pelas classes letradas, o que direciona à menção de Andries concernente à literatura popular do século XVIII atingir um público notadamente maior que o próprio livro, estando presente até mesmo, sob cantos de Natal, chants de Noël, de uma edição de colportage, na biblioteca de Marie-Antoinette, sendo ainda lida, por meio de seus antigos romances de cavalaria em papel azul, nos salões e boudoires da aristocracia. A propósito dos almanaques, sob a perspectiva do alcance de um vasto público, tem-se uma maior expansão de tal natureza, posto que seus calendários, prenúncios astrológicos para o ano, eram dirigidos a todas as classes da sociedade ${ }^{2}$. Desse modo, os almanaques Garnier e Hachette, por estarem em um contexto citadino, ser editados por livrarias de grande prestígio da época, além de apresentar conteúdo abrangente no tocante aos saberes, e a baixo custo, são os próprios representantes da relevância de tal literatura em todas as esferas sociais. É por abranger a totalidade do conhecimento para cultivar os entes na arte de bem-viver, que Suassuna classifica os almanaques como livros característicos de uma espécie de protesto diante do mundo falsamente "moderno" em que vivemos, um brado contra o isolamento infecundo em que as Artes e as Ciências vão dividindo-se em especialidades

1 . Bollème, 1971, pp. 8 e 9.

2. . Andries, 1994, p. 9. 
cada vez mais espaçadas, cada uma delas egocentricamente apresentando-se como autosuficiente e superior em detrimento das demais. $\mathrm{O}$ autor ainda os aponta como protesto em relação ao racionalismo esgalgado e improdutivo dos cientificistas e como indagação concernente à ordem divina do princípio, em que tinhamos a perfeição e a totalidade ${ }^{3}$, e que nas cidades excelentes, Paris e Rio de Janeiro, do melhor dos mundos possíveis, são recobradas, ad infinitum, pelo fazer poético tecedor do Sublime.

Tal retorno simbólico ao excelente na Terra sem Males de almanaque, pelo saber totalizante cultivado em suas sessões, remete à importância que tais livros tiveram na divulgação do conhecimento a todas as classes, posto que se a Bibliothèque Bleue, segundo Andries, desaparece somente no fim do século XIX em decorrência da legislação concernente ao colportage - comércio ambulante, tornar-se mais severa e, sobretrudo, da mudança radical no que tange à larga difusão das formas de leitura, observa-se que no século XX, pela comercialização do Almanach Hachette, a filosofia primeira de tal coleção, de visada pedagógica e vocação enciclopédica, é recuperada ou continuada já em sua classificação de Petite Enciclopédie de la Vie Pratique. A essência da literatura de colportage, e estendemos para a literatura popular brasileira, é mantida ainda que pela venda dos almanaques pelas grandes livrarias Hachette e Garnier, posto que se o contexto de analfabetismo é em torno de 80\% no Brasil na chamada Belle Époque, na França com seus milhões de leitores, segundo Mollier, da gazeta cotidiana em 1900 e dezenas de milhares de amadores de romances populares - 80000 exemplares para o Chaste et Flétrie de Charles Mérouvel em 1905, 88000 para a primeira tiragem de Lourdes, Rome et Paris de Émile Zola em 1894, 1896 e 1898 mostram a amplitude concernente à mudança que a França conheceu em matéria de alfabetização e de difusão da impressão no decorrer de cinquenta anos ${ }^{4}$, realidade que certifica a relevância, tanto no Brasil como na França, de tais livros populares para o desenvolvimento do conhecimento, por se tratar de uma literatura de baixo custo e acessível a diferentes classes conforme sua origem.

$\mathrm{O}$ viés pedagógico e enciclopédico mantido pelos almanaques no século XX pode ser elucidado pelos diferentes saberes que divulgavam, astronomia, ciências exatas, artes, dentre outros, sem mencionar as receitas para ter uma vida farta de regozijo, o que direciona especificamente para o Ano Literário e Année Littéraire em consonância com o ato poético a cada feitura anual de almanaque, que aponta no Garnier uma relação de sugestões de autores

. Suassuna, 1927, p. 10.

. Mollier, 2004, p.215. 
e livros para leitura, como versos castelhanos, poesia japonesa, antiga e populares, crítica literária dentre as quais "O Plano dos Lusíadas" de J. Leite de Vasconcellos, além de rememorar suas origens com a menção, em 1910, ao folclore brasileiro por meio da "Peleja do Bem-te-vi com o Madapolão", uma cantoria entre trovadores populares, o que é notável, pois estando em um contexto de analfabetismo no nível de $80 \%$, já em tal período, a literatura popular e a "dita culta" são ministradas aos leitores, valorizando o canto popular em suas páginas que simbolicamente representam o balaio de onde saem os desafios cujo acorde dá-se no cotidiano repleto de encantamento.

A didática para a excelência é vista de maneira semelhante no Almanach Hachette, posto que no Année Littéraire a literatura é divulgada e organizada da seguinte forma: Les Principaux livres de L'Année, Les Chefs d'Oeuvres de la Littérature Allemande, Le Prix de la Pensée: Gains des Écrivains de Jadis et d'Aujourd'hui, Littérature, Romans, Poésie. O estímulo ao saber é ainda observado na sugestão de como deve ser a organização da biblioteca de um homem culto e íntegro, o que elucida a Paidéia Poética para o Ideal, conquistado na República das delícias, Paris - “La Bibliothèque d'un Honnête Homme - L'Honnête Homme c'est l'homme cultivé. C'est celui qui, par l'exercice de son esprit, cherche à comprendre la vie, et qui veut comprendre la vie pour tâcher de faire da vie selon l'exigence de sa raison. Cet homme doit lire. Les livres sont um complément nécessaire, um prodigieux agrandissement de l'expérience personnelle" (almanach / année littéraire 1906 et 1907).

Considerando que os almanaques Garnier e Hachette seguem o mesmo princípio de formação do ser para a totalidade e, por conseguinte, colaboraram de maneira significativa, na Belle Époque francesa e brasileira, para o desenvolvimento do conhecimento, sobretudo nas classes menos abastadas citadinas, o que remete ainda à origem da divulgação de tais livros, quando na França esse tipo de literatura era vendido e transportado pelos colporteurs, marchands-merciers, vendeurs d'images com seus fardos nas feiras e mercados, porta a porta ou de vilarejo em vilarejo, e no Brasil, pelos mascates, miçangreiros, vendedores de retratos, que também conduziam tal literatura em balaios e a vendiam nas feiras, mercados e de povoado em povoado,- e à recuperação de tal mercado ambulante pela ode itinerante inscrita anualmente com os feitos de seu povo. O perfil característico de tais vendedores, que na França partiam no outono para "faire du colportage", visto que no inverno os meios de sobrevivência eram difíceis, como plantar e colher, tratar de animais, etc, no Brasil, tem-se praticamente a mesma atividade, os miçangreiros que partiam na seca para vender uma infinidade de objetos, posto que cultivar e cuidar dos animais, em tal período, era 
extremamente problemático. É dessa maneira que os balaios iam repletos de novidades, traduzidas em objetos diversos e literatura, para lugares os mais longínquos, o que se rememora simbolicamente por meio do comércio do almanaque francês nas bibliotecas de estação da Livraria Hachette que, segundo Mollier, eram mais de mil em 1890², uma espécie de modernização dos cestos ou hôttes, visto que se o acesso era itinerante, permanece de certa maneira na modernidade, pois tais quiosques vão ao encontro dos leitores, ou passantes que simbolicamente flanam pela cidade, Paris, do melhor dos mundos possíveis.

É por meio do papel dos colporteurs - mascates, de vendedores, mas facilitadores do conhecimento, atualizado na modernidade, pelas livrarias Hachette e Garnier, com suas devidas disparidades sobretudo no que tange à visada capitalista nelas inerente, que se analisa a importância de tais sítios para o desenvolvimento e divulgação do saber, a primeira, segundo Mollier, - também nomeada Bibliothèque des chemins de fer, por se encontrar no período que vê aparecer a primeira linha de caminhos de ferro francesa e por ter se valido de tal inovação, - é fundada em 1826, pelo editor Louis Hachette no bairro das escolas, Quartier Latin, intelectual de origem modesta, que, nesse mesmo ano, no momento em que ia concluir brilhantemente seus exames finais no curso de Direito e que o estágio seria apenas uma formalidade a cumprir, parte para a edição. Tal mudança permite o nascimento de uma livraria prestigiosa, que se tornou a principal companhia de edição de livros europeia e quiçá, do mundo, o que pode ser elucidado pela contratação de grandes nomes da literatura como, Baudelaire, Flaubert, Georges Sand, Dickens, Gogol, dentre outros, e pelo volume de negócios, nos últimos anos, que saltou para 18 milhões em 1878 e para 58 milhões às vésperas da Primeira Guerra Mundial ${ }^{6}$.

De forma semelhante, o "faire du colportage" é modernizado na figura da Livraria Garnier, situada à Rua do Ouvidor, fundada em 1844 até os anos de 1920, segundo Dutra, pelos irmãos Garnier, Baptiste Louis e Hippolyte. O primeiro chega ao Rio de Janeiro e principia suas atividades em sociedade com a livraria de seus irmãos, que fica responsável pela impressão das edições brasileiras, mas que em 1852 tem seu rompimento, no entanto, após tornar-se proprietário exclusivo da livraria, Baptiste mantém a edição e, em certa medida, a venda dos livros do Brasil em Paris, além da venda dos títulos no Brasil, traduzidos ou no original, publicados pela editora parisiense Garnier Frères. A livraria logo se torna a principal casa editorial brasileira em detrimento das outras aqui estabelecidas, com o exercício

5. . Mollier, 1999, p.448.

6. Ibidem, pp. 8, 11, 12, 448. 
de edição e compra dos direitos de publicação de obras dos mais relevantes nomes da literatura nacional da segunda metade do século XIX. A autora ainda menciona que após a morte de Baptiste Louis, seu irmão Hyppolite conserva a livraria no Rio de Janeiro nomeando um gerente, Julien Lansac, que empreende um trabalho de reforma e a reinaura em 1901, contratando para consultoria dois grandes nomes do meio intelectual em questão, Ramiz e João Ribeiro. É essa nova etapa da livraria, sob os auspícios da Garnier Frères de Paris, que se produz, em 1903, o primeiro número do Almanaque Brasileiro Garnier, publicado até o ano de $1914^{7}$. Com vocação pedagógica para a integralidade do Homem semelhante a dos primeiros almanaques, mesclada a uma pedagogia para desenvolvimento da nação no início do século XX, na nova ordem republicana, o Almanaque Brasileiro Garnier em consonância com a Livraria, age como importante divulgador de cultura e colabora para a cessação da escassez de leitura no País, organizando concursos literários e ministrando conhecimento em todos os campos do saber. Aquela que engendra os livros encantados para a cura do corpo e da alma, a Livraria Garnier, é sítio da intelectualidade da época, edita manuais escolares, livros e contrata autores renomados da época como Sílvio Romero, Araripe Junior, Machado de Assis, dentre outros, o que certifica sua relevância para o desenvolvimento das letras no Brasil.

São as duas grandes "fábricas de conhecimento", Livraria Garnier e Livraria Hachette, que fomentam o mercado de almanaquias do melhor dos mundos possíveis, posto que se os livros ali engendrados colaboram para o cultivo dos cidadãos franceses e brasileiros, são em dialogo com a Paidéia Poética de almanaque, de formação para a excelência, a tradução simbólica da educação ideal nas Repúblicas das delícias, Paris e Rio de Janeiro. Como campos de lisibilidade poética, as duas livrarias fundadas por dois cidadãos franceses em parceira de edição e de venda, já não conhecem fronteiras, o que representa o intercâmbio de almanaquias para deleite entre as cidades ideais da Terra sem Males de almanaque, cuja sustentação da passarela quimérica, dá-se por meio das pilastras de saberes, edificada pelo ato criador da legião de escritores de tais sítios maravilhosos, em consonância com a tessitura anual, pelo flâneur-poeta, das urbes dos sonhos. É em tal mercado feérico, não de mercadorias fetichizadas na modernidade, mas de novidades que saem de uma espécie de hôtte - saco dos antigos colporteurs - mascates, que inseridas no microcosmo místico-poético de almanaque, simbolizam a descoberta do novo ou do conhecimento terapêutico da cegueira representativa dos males do mundo moderno. Ora, é na cura da ignorância para alcance da Verdade, pela

$7 \quad$. Dutra, 2005, pp. 24 e 30. 
Paidéia Poética de almanaque e pela incessante produção de conhecimento advinda da impressão ininterrupta das máquinas das livrarias, que os cidadãos do melhor dos mundos possíveis obtêm as lições para resgate do Belo e conquista do Sublime na verdadeira idade de ouro, não a da Belle Epoque fracesa e brasileira, mas a do princípio onde se tinha a plenitude de uma vida repleta de regozijo.

É nas ruas de ouro em pó do Eldorado parisiense e brasileiro, cujas livrarias representam duas entre as muitas instituições que trabalham incansavelmente para a feitura da excelência alcançada pela infindável tessitura poética a cada edição de almanaque, que notase o diálogo entre os habitantes das polis ideais Rio de Janeiro e Paris, o que simboliza o trânsito livre dos povos em tal empírio terrestre, elucidado pela carta de um leitor, jornalista, do Almanaque Brasileiro Garnier para o ano de 1912, que faz as seguintes ressalvas:

A França tem seu esplêndido Almanach Hachette, que toda gente lê, porque contém informações interessantes sobre um grande número de coisas e de fatos da atualidade. Nós temos o Almanaque Garnier, que é, igualmente, uma publicação de utilidade incontestável, talvez mesmo para nós muito maior, porque contém assuntos que nos interessam de mais de perto e mais de perto se referem ao que é nosso. Revela ainda notar que, sendo a nossa produção bibliográfica de tal maneira escassa, sobretudo no que diz respeito a informações da nossa própria vida, máximé (sic) economia, e o Almanaque Garnier, tratando, como se trata, dos aspectos mais sérios da situação atual da nossa terra, e inserindo um número avultado de curiosidades puramente brasileiras, sobe por isso mesmo, de importância.

A equidade concernente ao primor dos almanaques corrobora a sua importância - posto que as informações do Hachette são interessantes e cultivam os leitores franceses sobre fatos da atualidade e sobre conhecimentos gerais, o Garnier, inserido em uma realidade de produção bibliográfica precária, trata de assuntos sérios da nossa terra e de curiosidades notadamente brasileiras, além dos outros saberes nele vinculados - no que se refere tanto ao diálogo Brasil-França aqui desenvolvido, como no fato de serem veículos relevantes para o desenvolvimento do conhecimento, que no microcosmo místico-poético simboliza a formação de cidadãos sábios e sãos, a fim de habitarem no melhor dos mundos possíveis. É, pois, não na impressão de Gutenberg caracterizadora do mundo moderno, mas na magia oriunda das diversas máquinas das livrarias, como "fábricas de sonhos" para tessitura de um mundo ideal, que imprimem o saber que liberta dos grilhões da caverna da modernidade, que já não trabalham sob o viés do lucro capitalista, todavia inseridas na excelência de tal sítio, recuperam o "faire du colportage" - comércio de porta a porta revelador das novidades ou do 
saber que curam o Homem das trevas da ignorância nas almanaquias, para eterno deleite, simbolizadoras do Sublime.

É na recuperação simbólica do comércio itinerante na Terra sem Males, - tanto pelos quiosques das estações ou do engendro das livrarias que recheia de conhecimento a hôtte de cada habitante das polis ideais, quanto pelos almanaques que passam de geração a geração e atualizam a vasta oferta de produtos dos antigos colporteurs - mascates, como pente, agulhas, tesoura, cera para sapato, literatura popular, dentre outros, - que a metáfora da epopéia é tecida nas páginas de tais livros herméticos, regatando, pela Poiésis, um tempo de deuses e heróis, fazendo da oralidade inerente a tal gênero o cantar dos prodígios de um povo, seja francês, seja brasileiro ou das nações excelentes do melhor dos mundos possíveis. É tal resgate da oralidade perdida por meio das leituras em grupo dos almanaques, dos jogos e brincadeiras propostos ou na recuperação do narrador benjaminiano pela contação de seus causos de geração a geração, que remete às praças públicas das polis antigas como salvação do isolamento característico das grandes cidades, Paris e Rio de Janeiro, um dos males da modernidade, o que Bakhtine elucida no curso das épocas, com as esferas mudas e invisíveis das quais o homen participou que deformaram sua imagem, cujo mudismo e cegueira que nele penetraram, deram surgimento à solidão. $\mathrm{O}$ autor classifica o homem privado como isolado, o homem por si, aquele que perdeu sua entidade e sua coesão, outrora determinadas pelo princípio de sua vida pública. A consciência de si mesmo provocou a perda do cronotopo popular da praça pública, que não soube mais encontrar outro, tão real, coerente e único ${ }^{8}$.

É na leitura daquele do grupo que era cultivado nas letras, haja vista o índice de analfabetismo, em torno dos $80 \%$ no Brasil, na época em questão, também nos jogos de entretenimento para após o jantar do almanaque francês e, consequentemente, de leituras por um eleito de fatos e histórias interessantes no mesmo grupo brincante, como recuperação do valor da palavra inscrito na imagen, segundo Zhumptor $^{9}$, dos ouvintes franceses assentados para ouvir, o lettré local - letrado local de antigamente, ler um livro, que se observa o resgate da confluência dos espaços interior e exterior da antiga Grécia, posto que os almanaques recuperam o colportage - comércio que enche os olhos de encantamento pelo novo, a volta ao externo em detrimento da intimidade burguesa caracterizadora do isolamento moderno, ainda retomam a oralidade inscrita na poeticidade cantada em cada abrir e fechar de tais livros, ou

$8 \quad$. Bakhtine, 1978, p. 282.

9 . Zumpthor, 1983, p.30. 
melhor, ad infinitum, na melodia sagrada que ecoa do Sublime, no melhor dos mundos possíveis.

É, pois, o regate da Poiésis em meio a seu aviltamento moderno pela tessitura incessante e de longo fôlego da metáfora da epopeia de almanaque, - celebradora dos feitos dos heróis da época, dos deuses atualizados em suas diferentes representações, dos acontecimentos grandiosos como guerras, terremotos, descobertas científicas, dentre outros, na Belle Époque brasileira e francesa, - que direciona à memória coletiva inscrita na oralidade recobrada e mantida pelos seus leitores, representantes auxiliares dos poetas transmissores e conservadores da verdade, ou do flâneur-poeta, que permite a retomada do Belo em meio ao Feio caótico para cura dos males da modernidade. A conquista da verdade e sua perenidade, garantida pelo alcance do Sublime no melhor dos mundos possíveis de almanaque, remete ao que Thomas, retomando Detienne (1967), elucida sobre a tradução do vocábulo "verdade", alétheia, que significa literalmente o oposto ou a ausência do "esquecimento" (léthe), o que auxilia na explanação do conjunto de ideias relacionadas à memória, às Musas e à poesia, tendo no fato de que tanto Homero quanto Hesíodo invocam as deidades não para obter inspiração, como a posteriori fazem os poetas helênicos, mas para ter acesso aos acontecimentos, ao que realmente aconteceu ${ }^{10}$.

É justamente a verdade, como ausência do olvidável ou como sinônimo do Sublime da Terra sem Males de almanaque, que a Poiésis possibilita a cada feitura anual, cuja tessitura perene, ainda que finita pela cessação da edição, em 1914 do Garnier e em 1980 do Hachette, é eternizada no melhor dos mundos possíveis gravado na memória coletiva dos leitores que, por sua vez, são os próprios poetas transmissores e conservadores do canto de seu povo nas futuras rodas de contagem de anedotas, de causos, de feitos heroicos, de eventos prodigiosos e de conhecimento adquirido na leitura e na instrução da Paidéia de todos os dias.

O alcance da verdade, por meio da estetização do mundo moderno, pela Poésis, remete aos capítulos que tecem o melhor dos mundos possíveis - cuja análise do corpus segue o recorte de 1903 a 1914, em um anacronismo condizente com a quimera de tais livros populares, uma espécie de onirismo cantado pelo aedo em um vai e vem tecedor da confluência dos estratos temporais, haja vista que a metáfora da epopeia de almanaque inscreve um decurso assegurador de um passado regenerado, de um presente a salvo dos males e de um porvir repleto de boa ventura - a ver: 1. Urbes dos sonhos: quimeras de almanaque; 2. Ascese à beleza dos deuses: alcance da plenitude; 3. Elixires para uma longa 
vida: bálsamos para todos os males; 4. Prognósticos de bien-vivre: uma cartomancia de deleites nas mãos do flâneur-poeta; 5. Fetichização de almanaquias: mercadorias de um microcosmo onírico; 6. Domesticação poético-cíclica do tempo: cronos domado pelos calendários. É, pois, a tessitura poética anual que permite a edificação das urbes dos sonhos inseridas na Terra sem Males de almanaque do primo capítulo, e que constituem o microcosmo místico embebido de poeticidade onde os leitores ou já habitantes de tal sítio maravilhoso, alcançam o Belo que não se esvai com o decurso no segundo capítulo, mas permace ad infinitum pelo alcance do Tempo Sagrado na nova Criação. No capítulo subsequente, a conquista da verdadeira beleza do mundo, pela Poiésis, é possibilitada pela prescrição da Paidéia Poética de bálsamos para o corpo e para o espírito, uma espécie de terapêutica para os males da modernidade, cujo tratamento com doses de poeticidade liberta os leitores da falsa aparência moderna. O tratamento das mazelas para resgate do Belo e conquista do Sublime remete ao quarto capítulo, no qual os leitores dos almanaques têm a proteção, dos representantes do universo do sagrado, tanto para as intempéries diárias quanto para possíveis problemáticas que impeçam um destino repleto de boaventura. Tal universo resguardado dos males modernos é a própria mimesis delatora do utilitarismo e da ideia exacerbada de progresso, que, no quinto capítulo, transforma o fetichismo das mercadorias e da ratio circundante em almanaquias para sonhar com o melhor dos mundos possíveis. No último capítulo, o Tempo Sagrado tecido pelo aprisionamento simbólico de Cronos nos almanaques, pelo ato poético a cada feitura de almanaque, permite o alcance do Sublime na idade de ouro atualizada, a do princípio do mundo que combate os males da chamada Belle Époque. Vale ressaltar que a conquista do Sublime no melhor dos mundos possíveis de almanaque realiza o ideal da República de Platão - bem como da divisa joie de vivre da Belle Époque francesa que se inscreve no período de 1900 a 1914 e da brasileira entre 1898 e 1914, interregno que aponta crescimento econômico em vários setores, malgrado a inacessibilidade a tal progresso pela maioria - curando os leitores da ignorância, pela Paidéia Poética, para habitarem nas Repúblicas das delícias, Paris e Rio de Janeiro, utilizando como material para o término do acabamento da Terra sem Males, a poeticidade resgatadora dos leitores da caverna moderna que impede o alcance da Verdade. 


\section{Urbes dos sonhos: quimeras de almanaque}

Considerando o estudo comparativo entre o Almanaque Brasileiro Garnier e o Almanach Hachette, visa-se aferir que na tessitura anual, pelo flâneur-poeta, das Repúblicas das delícias, Paris e Rio de Janeiro, a organização harmoniosa do macrocosmo pelo ato poético, é refletida no microcosmo hermético que, por sua vez, incide nas leis universais do Cosmo, o que simboliza uma espécie de "elixir das letras criador" capaz de sanar, com suas infindáveis leituras, as inquietações dos entes e de contribuir para uma existência repleta de boaventura pelo alcance do Sublime. Para isso, utiliza-se uma espécie de mito do microcosmo poético, que coloca o homem como mundo abreviado carregado de poeticidade, ordenando sua própria constituição humana com a ordenação do universo representativo do próprio engendro anual de almanaque, fazendo da utopia - nas cidades ideais, Paris e Rio de Janeiro um alimento diário capaz de obliterar os males da modernidade para conquista da verdadeira Beleza do mundo.

Nesse microcosmo místico-poético, o flâneur-poeta cria cidades ideais para livrar seus leitores das mazelas do mundo moderno, o que leva a considerar um viés quimérico em tais livros populares, carregado de tintas utópicas em suas diversas temáticas, tanto no que concerne a sua organização quanto nas suas pretensões, posto que tal salvação dá-se na recuperação, pela Poiésis, do Tempo Sagrado sem males, do in illo tempore inscrito na nova Criação anual de almanaque a partir da matéria caótica moderna.

Destarte, é importante ressaltar o papel da utopia no decorrer da história, posto que antes mesmo da primeira narrativa utópica de Thomas Morus, a humanidade sempre se alimentou de discursos utópicos. Já os filósofos da Antiguidade buscavam, em suas reflexões, apaziguar as catástrofes e reconstruir cidades totalmente devastadas por centenas de invasões, atitudes que visavam à construção de urbes protegidas dos perigos externos e da fúria dos deuses proveniente de deslizes de seus cidadãos. Vale acrescentar, que tais pretensões na polis antiga não se referiam a uma promessa divina ou a uma missão: 
les philosophes de l'Antiquité, comme Platon, n'ont cherché dans le chaos de leurs cités détruites, d'une invasion à l'autre, qu'à bâtir de nouvelles cites plus stables, mieux protégées des périls extérieurs et du courroux des dieux par les vertus des citoyens. Aucun n'a cherché hors des murs protecteurs de sa ville reconstruite une harmonie plus grande s'étendant au reste des hommes (...) Sans doute, Platon reconnaît le désir d'expansion des cités mues par un esprit de rapine, une volonté de satisfaire les besoins croissants de leurs citoyens; mais la cité antique ne se sent chargée d'aucune promesse divine ni d'aucune mission. (SERVIER, 1967, p. 16-17)

Dentre os discursos utópicos, é mister mencionar o pensamento ocidental que nasceu a partir da caminhada de Israel rumo à Terra Prometida e também durante a espera da vinda do Messias, o que atesta um ideal de cidade baseado na certeza da salvação pela promessa divina, o que é observado nas Repúblicas das delícias, posto que a conquista da Terra sem males na idade de ouro moderna, pela Poiésis, traduz o caráter divino da salvação dos leitores das mazelas da modernidade a cada nova Criação de almanaque, cujo microcosmo místicopoético já não representa o sítio que mana leite e mel, mas almanaquias para deleites, símbolos das ambrosias que nutrem o Tempo Sagrado, regenerador e vencedor da disputa com a inexorabilidade do decurso que leva consigo o Belo:

la pensée occidentale est née au cours de la marche d'Israël vers la Terre Promise et pendant l'attente de la venue du Messie, le Roi issu de la race de David. Cette croyance singulière a animé une conception nouvelle de la cité qui n'a plus besoin d'être un tracé magique réintégrant l'homme dans l'univers et l'emprisonnant dans les rites. Libérée de toute enceinte consacrée, la cité nouvelle est la réunion des hommes de bonne volonté; elle porte en elle un dynamisme qui lui est propre: la certitude du salut de chaque homme par la promesse de Dieu, l'attente de l'avènement du Christ à la fin des temps: une espérance qui reprend et résume le double espoir d'Israël. (Servier, 1967, p.19)

Para desenvolvimento da pesquisa, considerou-se a perspectiva utópica, visto que os almanaques Garnier e Hachette representam simbolicamente as cidades onde seus leitores vivem a salvo dos infortúnios da modernidade, Paris e o Rio de Janeiro, nas quais a excelência produz o resgate da idade de ouro hesiódica perdida, o ideal inscrito, pelo ato poético, no alcance da própria Terra Prometida metamorfoseada em nova Criação de almanaque, cuja volta às origens da Poiésis possibilita a recuperação do Tempo Sagrado representante da domesticação da inexorabilidade do decurso, em seus vários calendários, com seus respectivos dias dos santos e com seus outros representantes do universo do divino, como tradução da conquista do Sublime.

Nesse viés, elucida-se a tese da edificação das cidades ideais, no Almanch Hachette para o Ano de 1910, como explanação da atmosfera quimérica de tais livros herméticos, que apresentam simbólicamente a construção de urbes perfeitas, protegidas das problemáticas da 
modernidade, como simulação do mundo dentro de duzentos anos, Le Monde Dans Deux Cents Ans. É o que fez um escritor inglês e, colocado aqui como uma espécie de profeta em consonância com o universo místico e prognosticador dos almanaques, $\mathrm{H}-\mathrm{G}$ Wells. Tal enunciador apresenta presságios sobre as novas máquinas que surgirão, as invenções e as descobertas do porvir e da ciência. O escritor supracitado é visto como dotado de imaginação prodigiosa, o que atesta sua prática enquanto autor, concomitantemente é apresentado como detentor de um saber simbólico que lhe permite descrever a imagem profética e insigne, de acordo com o texto, da humanidade em constante mudança.

Já no início do texto, tem-se no título, o jogo simbólico representado pelo profetaescritor, apresentado como poeta, cujo nome por si só indica o seu caráter sonhador, mas que tem poder para prenunciar o porvir por meio da descrição do país onde tudo é paz, abundância e alegria, o Pays de Cocagne, Au Pays d'Utopie: Vision du Poète. O texto inicia por meio da abertura de uma cortina, como em um espetáculo no qual o mundo é representado dentro de duzentos anos, com a informação de que haverá as mesmas montanhas, os mesmos mares, os mesmos rios, mas com um manto novo, livre de seus ossos velhos e de seus músculos, com as reticências que prolongam o discurso. Ora, nesse universo diegético embebido de poeticidade, o narrador assegura ter passado três dias no país imaginário, cuja abertura da cortina permite o relato do que aí foi visto. Assim, o enunciador fala de tal país após a inevitável guerra, já com a mistura das raças e das classes, em que qualifica o combate como metódico, sem paixão, no qual os chefes das armadas dirigirão suas tropas sem vê-las, de bem longe, de um centro com arsenal geográfico e telefônico, onde os aeroplanos, os submarinos, os automóveis contornarão a morte e as imensas ondas magnéticas destruirão as cidades à distância.

Apesar do prenúncio de tamanha dimensão, o narrador-áugure assegura que após esse período de conflito, a paz reinará por toda a terra, definitivamente, o que manterá o estado mundial constituído pelo consenso entre os povos. A partir de então, a civilização seguirá uma caminhada paralela e proporcional à rapidez dos meios de comunicação. Logo, a promessa de paz é assegurada de forma simbólica aos narratários, ou leitores dos almanaques, como uma espécie de terapêutica diante das intempéries da modernidade, estando na Paidéia Poética o caminho para apaziguar as dores e os temores de uma possível guerra, a de 1914, bem como de salvá-los da falsa idade de ouro e de dirigi-los para o Sublime.

Nesse universo quimérico, o flâneur-poeta, mercador de ilusões, por meio da narrativa quimérica, oferta aos leitores o alcance das Repúblicas das delícias, Paris e Rio de Janeiro, 
sítios feéricos em que há receitas para os males da vida. A garantia de ventura das cidades perfeitas, nos almanaques, remete à eudaimonía, vida feliz, da pólis grega, sobretudo a construção da República, Politéia platônica, concernente à orientação filosófica de educação para formação dos cidadãos gregos. As proposições criadas por Platão em torno da Paidéia, formação grega, levam a refletir sobre a Paidéia Poética presente nas orientações de almana-

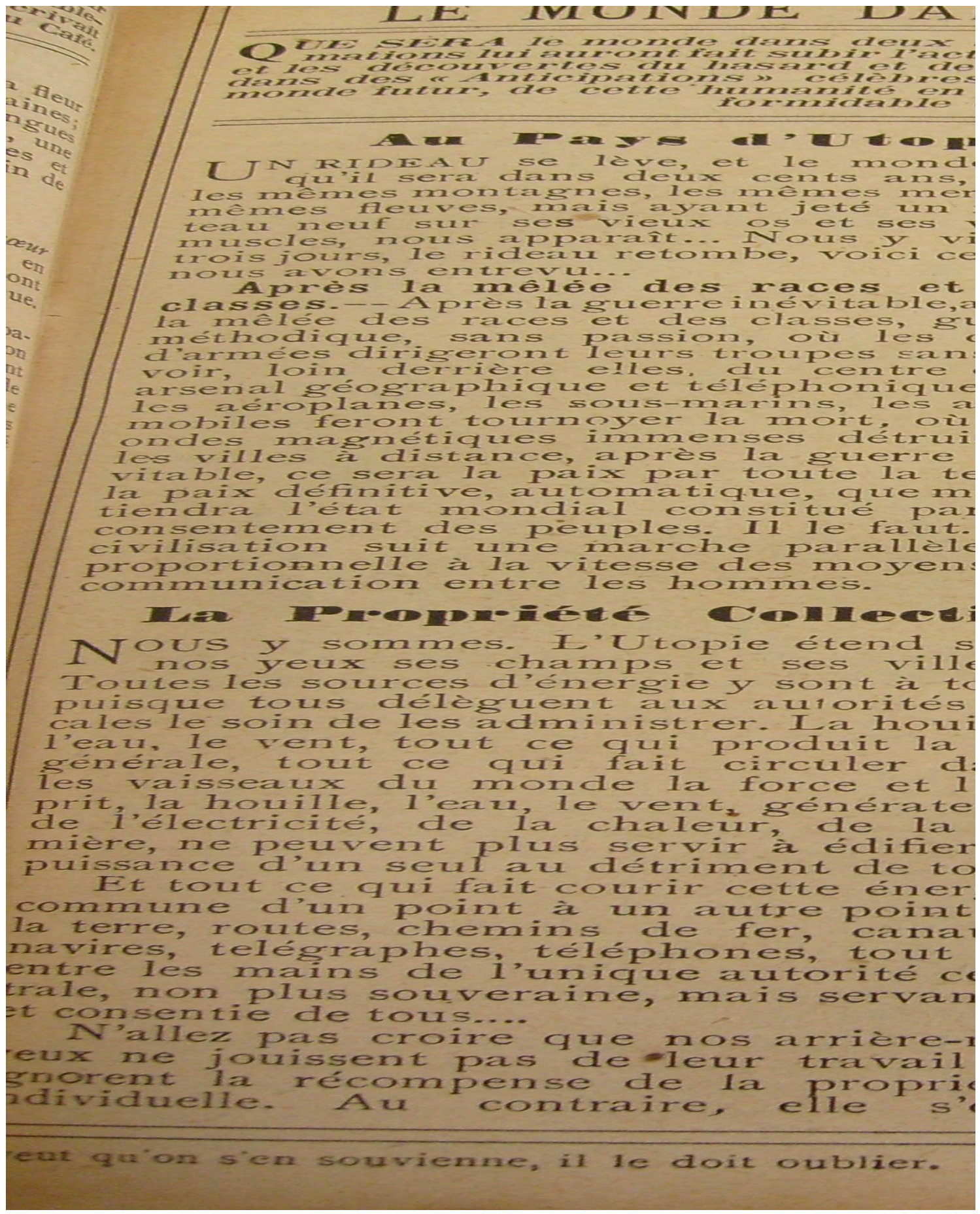


que do flâneur-poeta, sendo a construção do honnêtte homme, cuja vida de virtude e sabedoria garante a bem-aventurança, combinada ao universo do imaginário, a resposta para os males da modernidade. É, pois, como viés didático para formação do Homem sob a égide da equidade, que se considera a educação platônica concernente à justiça na República, elucidando na proposição de fundação da cidade perfeita, como sábia e corajosa, temperante e justa, a aclaração de que os fatos sadios geram a sanidade, em contrapartida, os doentios, a doença, a prática de ações justas a suscitadora da justiça e nos atos injustos, da injustiça. Prossegue com uma bela imagem comparando a virtude com a saúde, beleza e disposição da alma, em oposição ao vício, gerador da doença, feiúra e fraqueza ${ }^{11}$. É no arquétipo do Homem virtuoso platônico e da cidade da excelência, que a Paidéia Poética tece sua urbe ideal, com cidadãos nobres para a vivência do Sublime apagador dos males modernos.

Para tanto, o narrador-prognosticador garante que a comunicação será extremamente desenvolvida, com todos os meios possíveis, o que colabora para que os preconceitos de raça, casta, entre outros, desapareçam definitivamente. A língua oficial para Wells, como menciona o texto, será o francês. Ainda há a menção de que os povos voltarão a ser nômades, sendo misturados pelo sangue e pelo espírito, o que proporcionará a unidade planetária. $\mathrm{O}$ narrador afirma que tal paz será infindável, pois a guerra universal será a última das guerras, embora apresente um elemento que poderá modificar tal cenário idílico: a possibilidade de um acontecimento provocado por algo estranho advindo das profundezas do espaço, eliminando a profecia do país ideal, fato que é apresentado como praticamente impossível.

No país da Utopia, observa-se ainda a propriedade coletiva de fontes de energia, que é controlada por uma única autoridade central, não soberana, mas servil, com o consentimento de todos. Os trabalhadores usufruem de seu trabalho individual, pois cada um possue todos os instrumentos necessários para desenvolvê-lo, além de não haver a preocupação de acumular bens, com o intuito de extinguir problemas decorrentes da concentração de riqueza nas mãos de poucos. Por isso, o narrador-profeta assegura aos narratários de que não há o que temer em relação ao futuro, posto que a "Mutualitê" - mutualidade os resguarda de todos os riscos de ordem econômico-financeira. Em tal paraíso terrestre, nota-se ainda a garantia do asseio, do bem-estar e da erradicação da miséria, o que permite a supressão das moléstias, por conseguinte, a abolição de crianças mortas, de homens condenados, pelo frio e pela fome, a uma vida curta ou a uma velhice antecipada decorrente de má alimentação.

11 . Platão. A República, 2006, 427 e, 444 e, pp. 146 - 172. 
Considerando a narrativa concernente ao país da Utopia, destaca-se o jogo simbólico entre o autor - Wells e os leitores do almanaque francês que, por sua vez, são representados pelo narrador e pelos narratários, sendo pintados por um áugure maior, o flâneur-poeta, incumbido de trazer as boas novas em tais livros populares e o alento para os desassossegos da alma e do espírito, tendo na Poiésis a chave para abrir as portas que encerram o Sublime no Tempo Profano.

A promessa de uma vida extraordinária perdura nas cidades ideais Les Cités Idéales, seguida de uma imagem representativa das previsões feitas em 1828, cujo desenhista faz o croqui que presume grandes lojas, balões dirigíveis civis e militares, elevadores e automóveis, até mesmo grandes chapéus. Esse não hesita em colocar uma ponte entre Calais e Douvres, única predição não realizada segundo o texto. Diante disso, nota-se que a inquietação em relação ao porvir foi uma constante na história da humanidade, haja vista os clássicos Oráculos da Grécia, o que atesta a busca incessante do homem pelo controle do tempo e da vida. Observa-se ainda, na diegese quimérica, que o narrador aponta o progresso das cidades, com belos jardins, largos passeios arborizados, gramados, etc, também menciona a questão das vias públicas que permite aos transeuntes escolher, livre de perigo e da lentidão, o veículo apropriado para sua ocupação do momento. Essas cidades ideais apresentam o ar com mais poeira e mais carvão, calçamentos especiais que isolam o pé da terra e da eletricidade, eficazes na indústria e na habitação. A utopia ainda prenuncia que a máquina trabalhará sozinha a matéria agrícola e a industrial, não necessitando da força humana. Nessas urbes perfeitas, as estações meteorológicas prevêem as chuvas pela televisão sem fio, os granizos, as tempestades, as geadas e todas as maledictions- as maldições do céu tornam-se benefícios.

As cidades da excelência terão ainda grandes rodovias com dez acessos, para trens, automóveis, bicicletas e mesmo para pedestres. Nelas, canos imensos entre os oceanos, atravessarão as montanhas e transformarão os lagos da Europa em um mar ligado a todos os grandes rios, etc. Os lares possuirão ar e luz próprios, água quente e fria à vontade, a energia, a limpeza e a varrição automáticas pelo serviço da usina, comum aos habitantes, que produz a energia da cidade. Quanto às compras, haverá grandes lojas que entregarão em domicílio, mediante telefonema, dentro de minutos. Em relação à comunicação, pela assinatura de uma agência, os cidadãos terão notícias e se manterão atualizados diariamente por um aparelho fonográfico, luxo que não será restrito apenas aos abastados.

É nessas cidades que os narratários-leitores serão completamente felizes, tendo na profecia o papel simbólico de alimento que nutre e protege das problemáticas diárias, o que 
sustenta a tese de que os almanaques apresentam, pela Poiésis, legítimas fórmulas para apaziguar a dores da existência na modernidade, ainda que de forma quimérica e jocosa, posto que a estética do riso, mesclada ao onirismo, permite o resgate do Belo apagado pelas fealdades circundantes.

O país da Utopia também apresenta modelos de penitenciárias e outras previsões para a posteridade, feitas no ano de 1909, por meio de um croqui de M. A. Robida, que segundo Wells demonstra as transformações do mundo após um período de duzentos anos. Diante disso, tem-se a representação do futuro, com o céu repleto de aeronaves e de dirigíveis, a guarita do porteiro no décimo quinto andar, mais chaminés, consequentemente, mais fumaça, fábricas centrais que entregam comida em domicílio, canais atravessando os mares para transportar cartas e encomendas, e a promessa de que a mão de obra será aprimorada.

Para o ano de 1910, a previsão para as futuras penitenciárias segue o princípio do exílio mais brando se houver casos de criminosos, bêbados e ladrões, sugerindo que tal idílio será livre de tais mazelas, possivelmente com raríssimos casos. Nessa perspectiva, vê-se que na narrativa feérica o mar é apontado como possuidor de ilhas nas quais são instalados bêbados e criminosos incorrigíveis. Em torno de tais ilhas, uma esquadrilha de navios armados para impedir as fugas e as comunicações com o mundo. Ora, tais sítios regeneradores de entes, imersos no microcosmo de almanaque, são a própria estetização das mazelas características da falaz idade de ouro, cuja mimesis salvadora das problemáticas modernas, inscreve sob a égide da heroicidade, a metáfora da epopéia combatente das intempéries cotidianas, em que o mar de almanaquias abriga as ilhas repletas de ambrosias e de Paidéia, para que a comunicação com o mundo seja a conquista do Sublime após o longo período de bravas lutas, com monstros marinhos, sereias, gigantes, desastres, atualizados pelos diversos males da chamada Belle Époque. É na Paidéia diária, e na tessitura de Penélope metamorfoseada em ávida espera a cada nova edição de almanaque, que os leitores podem deleitar-se na leitura dos feitos de seu povo, em que a miticidade, resgatada em meio ao racionalismo calcado no utilitarismo, faz a magia resurgir na Ilha encantada como sinônimo do melhor dos mundos possíveis. 


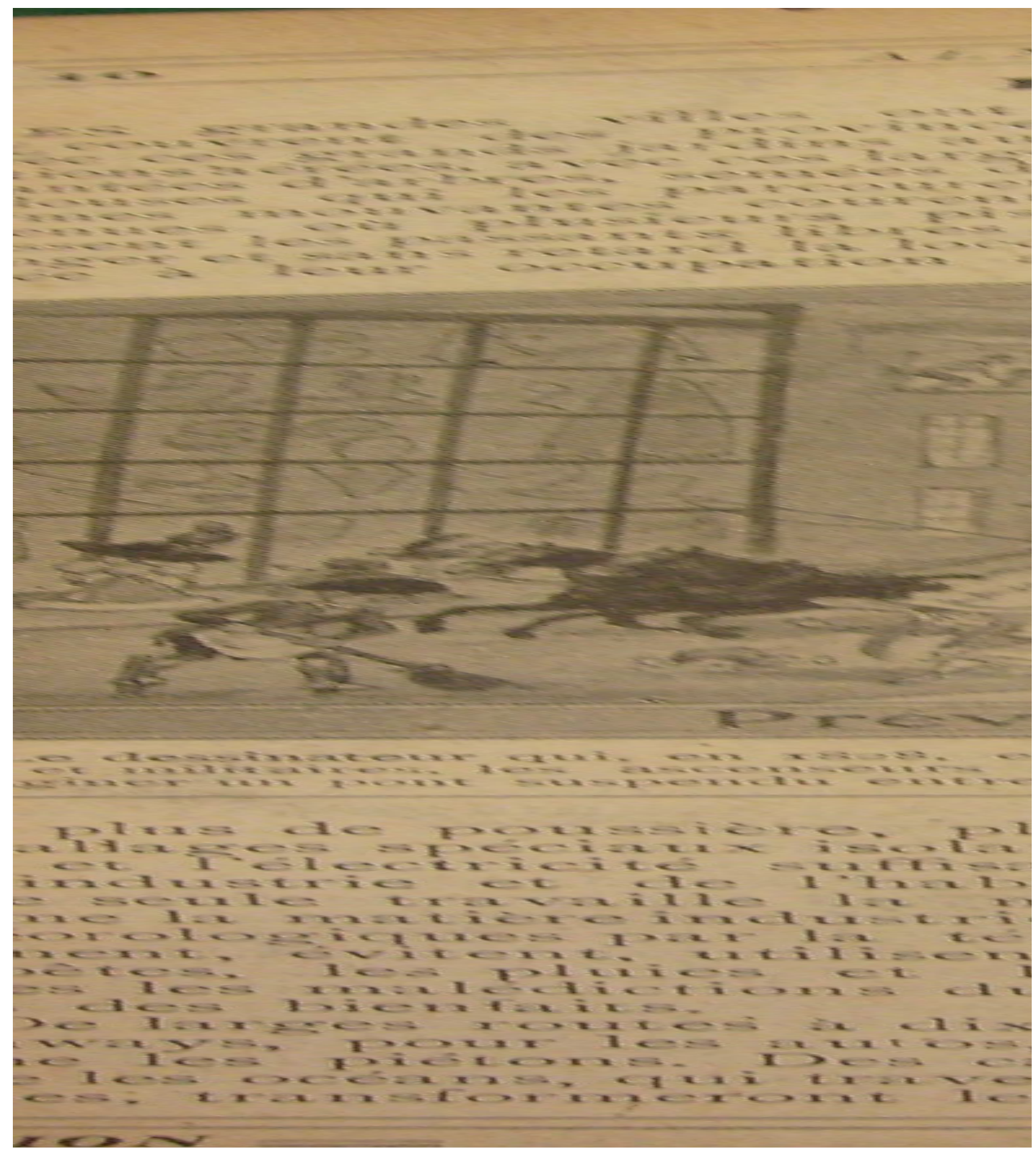

Nesse sítio, haverá ainda uma infinidade de sementes, máquinas agrícolas, todos os materiais elementares da vida civilizada, com o intuito de colocá-los à disposição daqueles que não adquiriram as virtudes necessárias, respeitando suas preferências. Desse modo, a promessa cumprir-se-á, a degenerescência findará e a possibilidade de viver em paz realizar- 
se-á, o que proporcionará uma regeneração completa do indivíduo que, por sua vez, tornar-seá sociável. Assim, as ilhas encantadas terão o poder para resgatar qualquer cidadão, como uma espécie de mágica que apaga quaisquer transgressões, o que coincide com Paidéia Poética que cultiva os entes para a Verdade e com a promessa de felicidade que os almanaques proporcionam em suas páginas.

Nesse microcosmo ideal, observa-se ainda uma nova lei - La Loi nouvelle, baseada no conjunto das experiências venturosas do indivíduo - exceto com algumas proibições - como a plena liberdade de escolha, a plena liberdade de ser vencido e de vencer, sendo possível colaborar com uma pedra para a construção mundial. Para finalizar a promessa do empíreo terrestre, tem-se a garantia de que a plena paz não será assegurada nem pelo socialismo e muito menos pelo individualismo. Assim, o narrador/profeta conclue com uma indagação Qui sait ce revê n'est pas susceptible d'une complète réalisation?... Considerando o texto prenunciativo, a sua conclusão é um questionamento afirmativo quanto ao seu cumprimento, reforçando a esperança do Pays de Cocagne por meio das retiscências que não concluem o presságio, mas que representam a infinitude de boa ventura no microcosmo místico-poético de almanaque.

Isso posto, afere-se que o universo simbólico dos almanaques franceses e brasileiros segue o princípio das profecias, pois todas as fórmulas de felicidade, seus diversos elixires, seus modelos de cidades ideais, seus calendários para controle do tempo e da vida, seus astrólogos que prenunciam o porvir, entre outros, remetem à busca pela vida abundante e afortunada do Pays de Cocagne, no Almanach Hachette, e do Mito de São Saruê e tantas outras profecias do Brasil no Almanaque Brasileiro Garnier. Ora, discorrer sobre a tão sonhada conquista do Pays de Cocagne leva a considerar o modo como Thierry Paquot define tal empíreo na Terra, apresentando o fato de sua etimologia ser ainda misteriosa, mas que segue a idéia de abastança (em holandês, "país das maravilhas"; em alemão e em inglês, "país dos doces"; em francês, o termo surge do provençal, em que "cocagne" significa "pastel de nata" e simboliza a prosperidade). Nesse País das Maravilhas o autor menciona que se resiste à pobreza, não por uma revolução na propriedade, mas realizando banquetes, ficando no ócio - à toa - e dançando ${ }^{12}$. É nesse viés que se desenvolve a análise do universo do Almanch Hachette, pois o flâneur-poeta cria uma cidade utópica para seus leitores, Paris, inserida no país, a França; o Pays de Cocagne que, por sua vez, compõe o melhor dos mundos possíveis, visto ser ele um profeta metropolitano, mas que está com os pés firmados nas riquezas

12 . Thierry Paquot. A Utopia (Rio de Janeiro: DIFEL, 1999), p. 25. 
populares da província. Então, é nessa cidade quimérica que os leitores podem sonhar, seja com a fartura, seja com a felicidade que vence todas as intempéries, com a promessa de uma vida longa e prazerosa a cada feitura de almanaque.

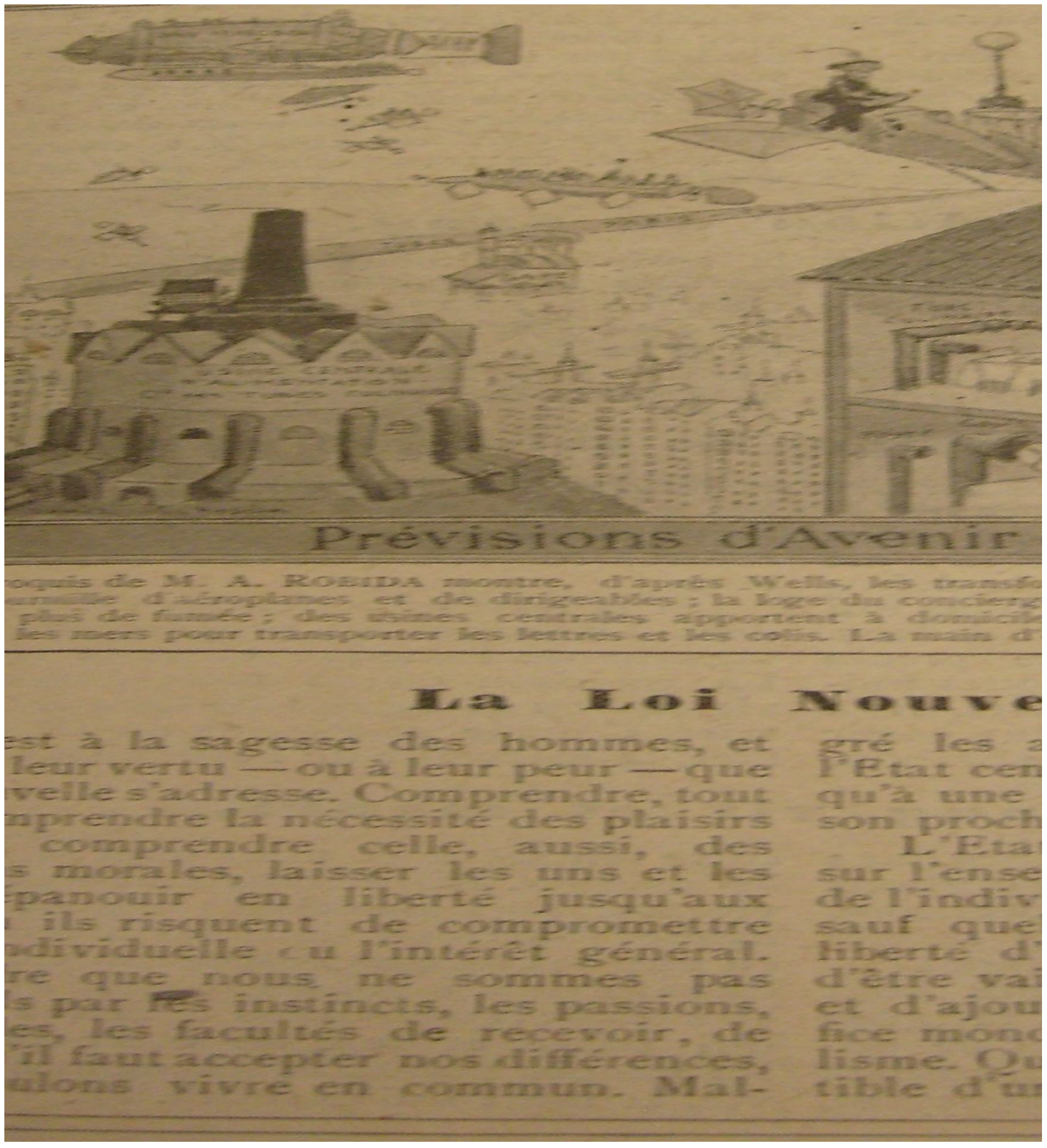

De forma semelhante, considera-se a busca pelo País da Utopia no Almanaque Brasileiro Garnier, visto que o flâneur-profeta também constroe - a cidade ideal, Rio de 
Janeiro, no microcosmo místico-poético, que da mesma forma integra um dos sítios da Terra sem males, - por meio de uma infinidade de fórmulas de bem-estar, o que remete às profecias brasileiras que alimentaram e continuam nutrindo o imaginário coletivo. Assim, inicia-se pelo País de São Saruê, que segundo Tettamanzy nasce na literatura popular nordestina. A autora analisa o folheto de cordel intitulado Viagem ao país de São Saruê que faz parte de todo um universo maravilhoso característico da literatura de cordel brasileira. O maravilhoso de tal gênero popular vem acompanhado de uma visão religiosa da vida, tendo os folhetos de cordel chegado no Brasil pelos marinheiros portugueses, que influenciaram com sua perspectiva utópica decorrente do renascimento, a literatura popular, o que permanece na tradição oral. É então nesse país, que se observa fartura, do folheto de Camilo dos Santos, "Só em São Saruê, onde feijão brota sem chovê", a elucidação da riqueza de tal lugar, além de mencionar os elementos tipicamente nordestinos que traduzem a sua abastança: "das árvores brotam a mandioca, a pamonha, a pipoca, ou as pedras são de queijo e rapadura e o café já está coado nos poços"13. Considerando o mito de São Saruê, observa-se que a fuga simbólica da miséria decorrente da seca e característica da região nordestina, dá-se pela leitura do folheto e pela crença coletiva na existência do país maravilhoso.

O mesmo é notado em outras profecias brasileiras citadas por Câmara Cascudo ao mencionar o Sebastianismo d'El-Rei D. Sebastião, o sebastianista do quinto império, o Padre Antônio Vieira estudado pelos professores Raymond Cantel e Hernani Cidade, as predições do Frei Vidal de Frascarolo, missionário que pregava o Inferno como caminho para o paraíso, as "visões celestes" de Padre Ibiapina cearense de Sobral, os prognósticos do imortal Antonio Conselheiro, entre outros. É o que o autor classifica como literatura profética, sendo denominada ainda como primorosa para a sobrevivência mental das atividades intelectuais. Prática que faz do homem intérprete da Divindade, com prenúncios do porvir, o que satisfaz a ânsia pela penetração no Sobrenatural, revelando e apregoando o segredo dos deuses longínquos, essencial para suprir a necessidade da inquietação sobre o desconhecido. Ainda coloca tais presságios como alternativa para ultrapassar a limitação humana do complexo da Onipotência inexplicável ${ }^{14}$. Essa busca pelo porvir, tendo o profeta como representante da

13 . Ler artigo de Ana Lúcia Liberato Tettamanzy, professora na Universidade Federal do Rio Grande do Sul, intitulado Mitos Utópicos: da idade de ouro à "terra sem males", que analisa três textos de épocas e locais distintos, a epopeia de Gilgamesh, o folheto de cordel Viagem ao país de São Saruê e a narrativa sobre a "Terra sem Males" dos índios Guarani, para tratar das relações entre mito e literatura sob a perspectiva da ideia de utopia, Porto Alegre, p. 231-239, jul/dez 2007.

14 . A análise feita sobre os presságios na história da humanidade está inserida no capítulo "Profecias" da obra de Luís da Câmara Cascudo Superstições no Brasil, 2002, p. 450 - 459. 
Divindade, é vista no Almanaque Brasileiro Garnier, por meio da figura do flâneur-poeta que tem poder tanto para prolongar a vida, com suas receitas sagradas, quanto desvendar e assegurar o porvir através da leitura dos astros, dos astrólogos, da proteção dos santos e de outras práticas do universo místico-poético.

Ora, a oferta do Eldorado francês ou da República das delícias, Paris, é elucidada de forma semelhante no almanaque brasileiro para o ano de 1904, tendo no poético a salvação para os males da modernidade, bem como a conquista do Sublime por meio do poder das Musas, que permite ao flâneur-poeta o convite aos leitores para o retorno à idade de ouro, ao in illo tempore da Criação, intrepretada na tessitura anual da cidade quimérica, Rio de Janeiro. Logo, se no Pays D'Utopie: La visión du poète do almanaque francês, tem-se a conquista do melhor dos mundos possíveis, também se observa no almanaque brasileiro a garantia de alcance do Eldorado por meio da Poiésis, ou seja, O Eldorado de Edgar Allan Poe como receita da dieta poética aos leitores, para adentrar no microcosmo onírico de almanaquias. É, pois, na elucidação do cavaleiro, moço e formoso cavalgando pelo mundo à procura do Eldorado, que se nota a temática da Eudaimonía, vida feliz, prometida aos leitores. A busca pelo idílio perdura na segunda estrofe, destacando a extenuação do rapagão por ter corrido o mundo inteiro e não ter encontrado o menor sinal da terra prometida, Eldorado. Prosseguindo sozinho, na estrofe subsequente, desolado e fatigado, eis que surge a sombra de Ashaverus Rebellado, com quem dialoga, malgrado o assombro, à respeito da prodigiosa terra do Eldorado. 


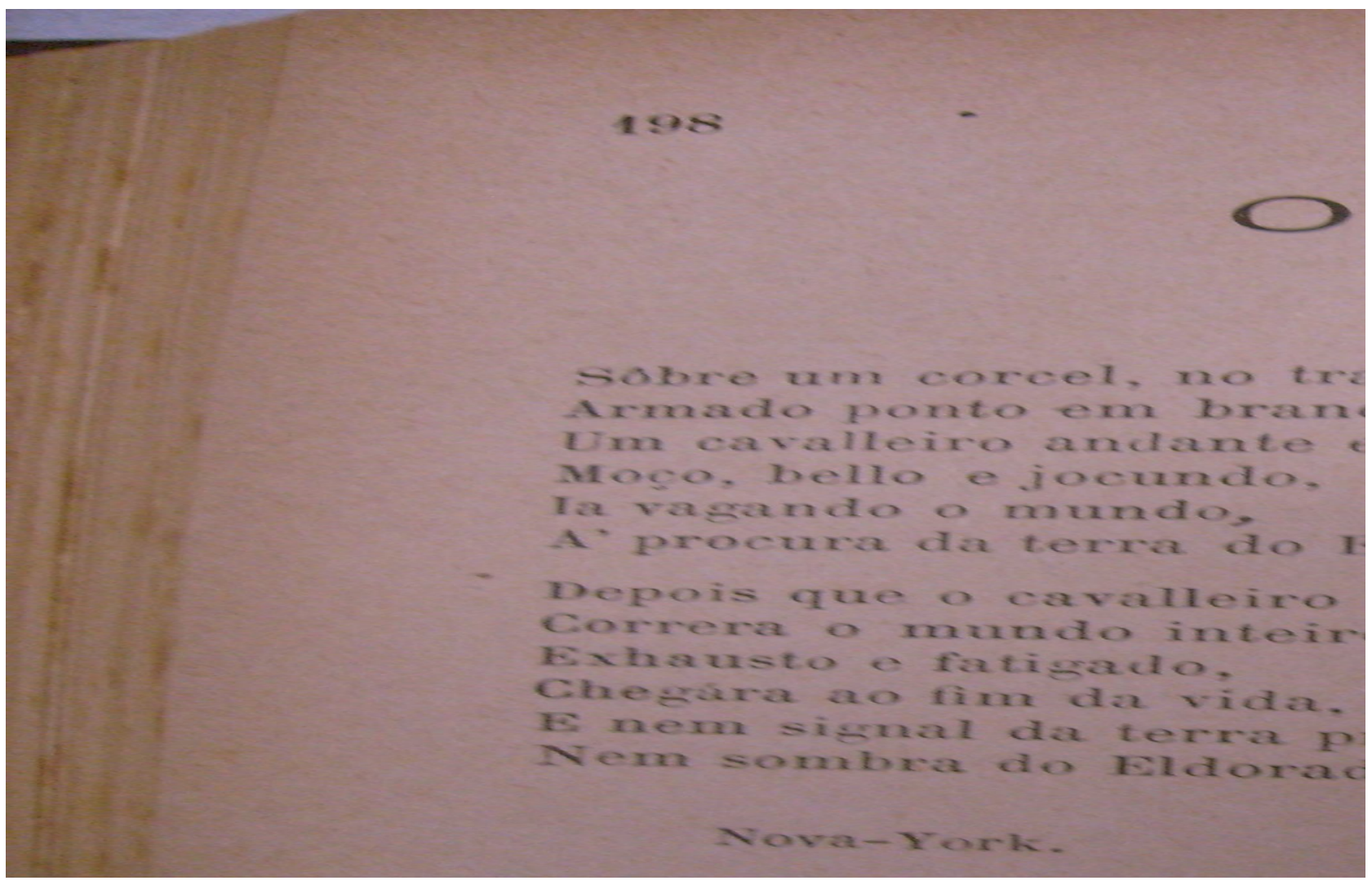

O poema finaliza com o sarcasmo de Rebellado, respondendo a indagação do belo moço, salientando que possue a mesma sina, a eterna busca da tão sonhada terra prometida. Então, juntos à galope, avistam a terra do Eldorado ou o reino de delícias. Ora, é por meio da Poiésis que a cidade ideal é conquistada, tendo na tessitura por meio do fazer poético, a construção da Verdadeira terra prometida, ou seja, a rememoração do mito que possibilita a recuperação da gênese sem males, a idade de ouro perdida. É dessa maneira, que o flâneurpoeta, por meio da Paidéia Poética, orienta seus leitores, educando-os na arte que leva ao Sublime, à Verdadeira Beleza do melhor dos mundos possíveis de almanaque. É por meio da educação poética dos leitores, a Paidéia de almanaque, que se nota a formação de cidadãos condizentes com o ideal da urbe dos sonhos, o que remete à primeira Grécia com seus poetas, educadores responsáveis pelo desenvolvimento integral do Homem. A educação pela poesia direciona ao que Jaeger ${ }^{15}$ menciona ao elucidar a temática da arete na formação do homem grego, como vocábulo que representa o ideal cavaleiresco de conduta cortês e nobre,

15 . Para melhor compreensão da formação grega, ler do Primeiro Livro intitulado A Primeira Grécia, Nobreza e Arete, da obra Paidéia A Formação do Homem Grego, de Werner Jaeger, Martins Fontes, 1994, p.25 e 26. 
associado ao heroísmo belicoso, tendo na virtude a representação da nobreza almejada na formação da totalidade do humano. $\mathrm{O}$ autor ainda faz referência ao liame característico do conceito de arete no que concerne não apenas à excelência humana, mas também à supremacia dos deuses e à bravura e rapidez dos cavalos de raça, considerações adotadas por Homero e outros poetas, bem como a última feita por Platão na República, ao considerar a arete dos cães e dos cavalos. E por meio dessa poesia didática que enobrece o corpo e o espírito, que se dá a edificação e a conquista do Eldorado com seus cidadãos formados pela mais alta arete, aquela que permite sonhar nas ruas de ouro e de almanaquias, tendo na consciência pedagógico-onírica que perpassa todas as seções dos almanaques, o caminho poético que permite o alcance da plenitude em todos os âmbitos da vida. É na volta à gênese do fazer poético, como modelo educacional que abre os olhos da alma para o Belo, interligado a uma rede mítica que personifica o ideal humano ansiado, como uma espécie de educação para a excelência, que se observa o alcance do Sublime, prognosticado pela mística da Poiésis de almanaque, na urbe da Criação, sem males e repleta de regozijo.

Mediante o viés educativo da poética de almanaque, é importante mencionar o mito das cinco idades de Hesíodo, que segundo Jaeger ${ }^{16}$, dá-se na elucidação de um passado ideal, o mundo heróico da epopéia, em contrapartida à idade de ferro considerada como hodierna, sendo o poeta um guia ou mestre de seu povo, assemelhado aos profetas de Israel já apresentado em tempos antigos, aquele cuja missão poética busca tirar o Homem dos enganos da vida e trazê-lo para um caminho de nobreza. Da missão educativa do poeta na primeira Grécia e da idade de ouro apontada por Hesíodo, lê-se como volta ao ideal que salva os leitores dos males da modernidade, tendo no flâneur-poeta uma sorte de aedo da epopéia simbólica de almanaque, o responsável pelo resgate do in illo tempore, a conquista da polis ideal, do Eldorado ou do melhor dos mundos possíveis, cuja máxiama inscreve-se na vida virtuosa e feliz.

É nessa atmosfera quimérica que o flâneur-poeta constrói suas cidades ideais, como Paraísos Terrestres, tendo em cada edição de almanaque, os segredos para adentrar no universo de delícias e de prazeres, passando aos leitores a impressão de que em seus vários volumes o tempo está ali, cronometrado durante o ano todo, protegido simbólicamente de sua passagem inexorável, caracterizando uma espécie de mito da eternidade, haja vista que passam de geração a geração e são guardados para ser lidos durante anos. 
Pode-se dizer que as urbes dos sonhos são edificadas por meio de um jogo simbólico, direcionado para a sustentação das cidades perfeitas, Rio de Janeiro e Paris, resguardadas das mazelas da modernidade. A tessitura poética de tais urbes visa o bom desenvolvimento das virtudes de seus cidadãos, contribuindo para o bom andamento do Eldorado popular, tendo na utopia o caminho para a erradicação dos obstáculos que colaboram para a ineficácia da Paidéia (formação grega) lisível como educação carioca/brasileira e parisiense/francesa, ou cultivo poético por meio de lições de bem-viver, cujo objetivo é a constituição e proteção do honnête homme dos males ou dos vícios característicos do mundo moderno, disseminados pela abertura simbólica da caixa de Pandora, mas recolhidos e trancafiados, para jamais emergir, na idade de ouro de almanaque.

A feitura incessante das cidades ideais a cada edição de almanaque, como uma espécie de estetização do mundo circundante para salvação de seus habitantes da aparente ordem moderna, remete à Paidéia Poética que cultiva os leitores pela terapêutica curativa dos males da modernidade, a fim de que sãos, possam enxergar o Belo como preparação para o alcance do Sublime na idade de ouro do melhor dos mundos possíveis. Ora, é pela tessitura ininterrupta dos Eldorados supracitados que a pedagogia poética orienta os leitores para a formação excelente, o que pode ser elucidado pelo texto intitulado A Sorbonne e o Brasil, do Almanaque Brasileiro Garnier para o ano de 1912, que informa a abertura do curso de Literatura Brasileira na Universidade de Paris.

É a Paidéia Poética que permite a ponte quimérica entre as Repúblicas das delícias, Paris e Rio de Janeiro, posto que se a urbe parisiense busca conhecer a formação histórica do povo com quem simbolicamente intercambeia almanaquias, e instruir os seus habitantes a respeito daqueles que vivem a mesma idade de ouro moderna, o diálogo é tecido como mimeses que rompe as fronteiras entre os países para tessitura da harmonia do melhor dos mundos possíveis. Nessa perspectiva, a Paidéia Poética informa que o conselho da Universidade de Paris resolveu abrir o curso de literatura brasileira, cuja organização ficou sob os auspícios de Oliveira Lima que, inaugurando-o, versará sobre a Formação histórica da nacionalidade brasileira. Ainda atenta para o fato de que não há necessidade de enaltecer a importância de tal obra e a supremacia do responsável a quem ela foi confiada, sendo as seis primeiras conferências, para conhecimento do "Eldorado Brasileiro", datadas no período de 15 de março a 7 de abril e as seis últimas de 24 de abril a 15 de maio. A pedagogia para instrução dos leitores ainda prossegue confirmando a relevância de tal feito ao mencionar que é a primeira vez que um grande Instituto Oficial Europeu, e justamente o de maior prestígio e 
o de mais respeitável tradição, cria um curso de assuntos brasileiros. Ora, é tal diálogo que reforça o estudo comparativo aqui desenvolvido, não apenas pela presença acentuada da cultura francesa na chamada Belle Époque carioca, mas também pelo interesse no conhecimento da formação histórica da nacionalidade brasileira por parte da Universidade Francesa, o que permite o cotejo elucidativo concernente à identidade dos habitantes que povoam simbolicamente o melhor dos mundos possíveis.

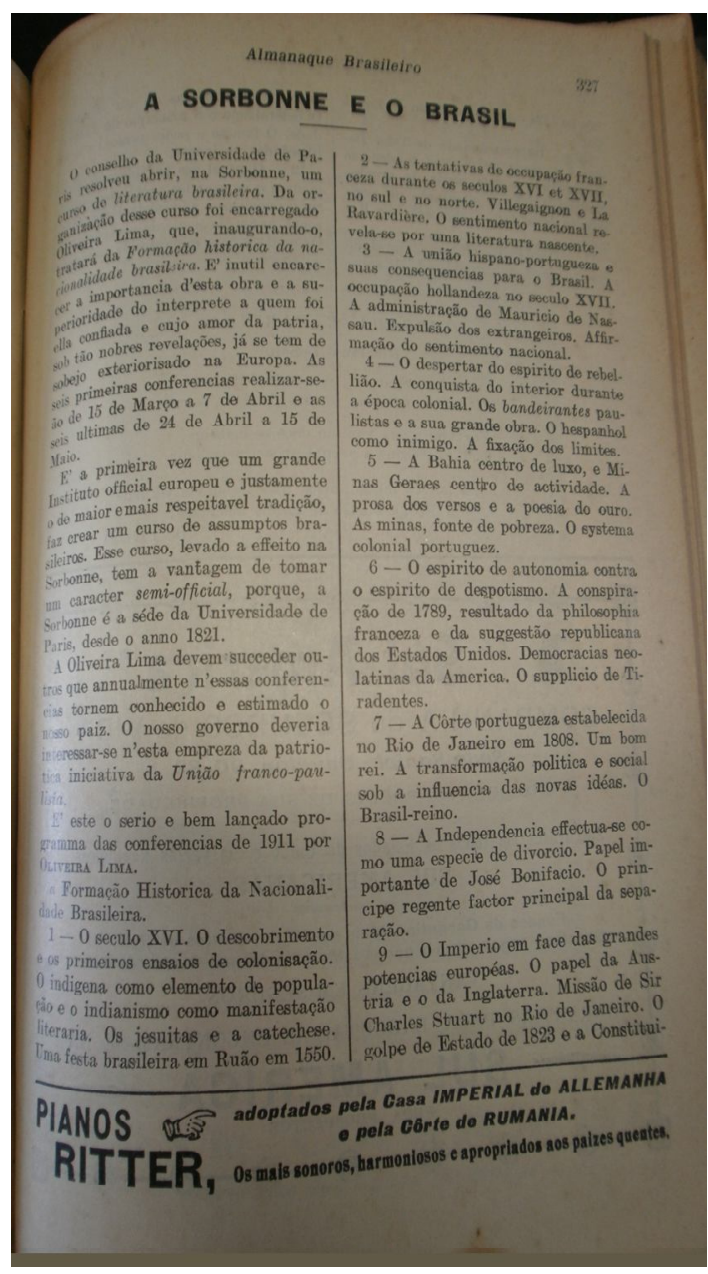

O cultivo dos habitantes das Repúblicas das delícias dá-se no mais alto grau de excelência, posto que não apenas a formação histórica da nacionalidade brasileira faz parte da Paidéia Poética no almanaque francês, mas também os inúmeros assuntos franceses tratados no almanaque brasileiro, bem como um conteúdo vasto que versa sobre literatura e outras artes, história, geografia, ciências, economia, arquitetura, medicina, astronomia, astrologia, 
música, conhecimentos gerais, dentre outros, como se a educação dos cidadãos das polis harmônicas seguisse a integralidade da formação do Homem grego no século V a. c., do corpo e do espírito, remetendo à educação dos filósofos-reis da República de Platão, que também busca a perfeição condizente com o Ideal de cidade inscrito no modelo divino. Desse modo, observa-se que a Paidéia Poética preza pelo alto nível educacional nas sessões de almanaque, o que faz do curso ministrado na Sorbonne a elucidação de tal excelência, que ainda é ressaltado pela menção de que outras conferências, além das supracitadas, serão ministradas, o que reforça a ponte quimérica que liga as urbes ideais, fazendo com que o Brasil seja conhecido e estimado na França, destacando uma espécie de requisição ao governo brasileiro que deveria interessar-se pela patriótica iniciativa da União franco-paulista. Tal cobrança salienta o diálogo não apenas entre as Repúblicas das delícias, Paris e Rio de Janeiro, mas também, pela menção do acordo franco-paulista, com outra cidade do país, São Paulo, que também compõe o melhor dos mundos possíveis.

É a educação excelente para todos que permite a ventura dos habitantes das cidades ideais, como se o curso na Sorbonne não fosse restrito a uma ínfima parte, tampouco os ministrados nas intituições da urbe carioca, mas acessíveis ao conjunto dos cidadãos necessitados do conhecimento que permite a cura da ignorância, inscrita nos males da modernidade, para a contemplação direta da verdadeira beleza do mundo, o que direciona novamente à República platônica, no momento em que Adimanto questiona Sócrates a respeito da felicidade dos homens da cidade perfeita, comparando os que possuem propriedades e os que não as possuem, prontamente respondendo que sem nenhuma admiração até mesmo os guardiões da polis harmônica seriam muito felizes, posto que ao ser fundada, o propósito não era de que apenas uma classe fosse muito feliz, mas que na medida do possível, toda a urbe fosse ditosa. Acrescenta que tal ventura seria fruto da justiça, ao passo que em uma cidade cuja administração fosse má, teria-se a injustiça, o que toma como modelo para arquitetar a cidade de modo que ela seja afortunada, sem privilegiar poucos, visto que o objetivo não é fazer com que alguns sejam felizes, mas a polis como um todo ${ }^{17}$. É justamente tal felicidade que as cidades ideais, Paris e Rio de Janeiro, proporcionam a seus habitantes, visto que no microcosmo místico-poético de almanaque a equidade em todos os âmbitos da vida é exercida, o que permite a transformação das mazelas circundantes em estética libertadora das correntes que aprisionam os leitores na caverna moderna, tendo na educação que não visa a compartimentação dos saberes, mas a formação integral do ente, pela

17. República, 419 a, 420 a, b, c, pp. 135 - 136. 
Paidéia Poética, o caminho para a constituição de uma outra realidade, a Criação resgatadora do Belo, perdido em meio ao Feio da modernidade, para vivência do Sublime na atualização da idade de ouro sem males e sem preocupações de nenhuma ordem.

É a estetização da realidade no microcosmo místico-poético de almanaque que permite um tempo novo em que todos têm acesso ao conhecimento de maneira igualitária, visto que o programa - das conferências de 1911 por Oliveira Lima na Universidade de Paris é passado a todos os leitores, bem como aos franceses que agora podem instruir-se nos assuntos brasileiros, - é composto por doze itens que versam sobre a Formação Histórica da Nacionalidade Brasileira, dos quais segue uma súmula, a ver: 1. O século XVI. O descobrimento e os primeiros ensaios de colonização; 2. As tentativas de ocupação francesa durante os séculos XVI e XVII, no sul e no norte, O sentimento nacional revela-se por uma literatura nascente; 3. A união hispano-portuguesa e suas consequências para o Brasil. A ocupação holandesa no século XVII, A expulsão dos estrangeiros e a afirmação do sentimento nacional; 4. O despertar do espírito de rebelião, Os bandeirantes paulistas e a sua grande obra, O espanhol como inimigo; 5. A Bahia centro de luxo e Minas Gerais centro de atividade, A prosa dos versos e a poesia do ouro, As Minas, fonte de pobreza, O sistema colonial português; 6. O espírito de autonomia contra o espírito de despotismo, A conspiração de 1789, resultado da filosofia francesa e da sugestão republicana dos Estados Unidos, O suplício de Tiradentes; 7. A Corte portuguesa estabelecida no Rio de Janeiro; 8. A Independência efetua-se como uma espécie de divórcio; 9. O Império em face das grandes potências européias; 10. Impopularidade de Dom Pedro I causada pelas suas tendências autocráticas e pela perda da província Cisplatina, A abdicação e a Regência; 11. Dom Pedro II. Sua maioridade antecipada e seu aprendizado de soberano, Características do seu reinado; 12.O papel dos partidos constitucionais e os grandes problemas políticos econômicos e administrativos, Os motivos determinantes da mudança do regime.

É por meio dos tópicos que se observa o estudo sobre a formação do povo que constitui o Eldorado com o qual o Pays de Cocagne dialoga, que juntos, e somados a outros países maravilhosos, formam o melhor dos mundos possíveis no microcosmo místico-poético de almanaque, cujas almanaquias carregadas de poeticidade permitem a eterna ventura dos cidadãos na Terra sem males da idade de ouro modena, que jamais será sucedida por outra época, posto que a beleza reconquistada na estetização da realidade caótica da modernidade permite a vivência do Sublime na perenização do Tempo Sagrado que não se esvai com o decurso. 
É, pois, com a Paidéia Poética tecedora do Sublime, ou das polis excelentes, que se notam as lições de Poiésis para salvar os leitores da falsa aparência da modernidade, tendo na pedagogia da poeticidade a salvação da civilização utilitarista correlata. É na volta às origens da Poiésis que se observa a construção do in illo tempore de almanaque, com seu caráter educativo de formação do Homem para a Verdade, sendo os arquétipos divinos a própria égide sob a qual a urbes perfeitas são edificadas. Considerando o microcosmo místico-poético dos almanaques, observam-se similitudes com o universo dos deuses antigos, na medida em que se rememora o fazer poético ab origine, como elucidação da sacralidade de tais livros herméticos ou representação do Divino em suas páginas. Ora, tal menção às divindades na Poiésis remete às Musas, que segundo Commelin, eram filhas de Júpiter e Mnemósine, ou Memória, todas jovens e da mesma forma belas, ainda que diferentes no estilo de beleza. Eram nove de acordo com Hesíodo, tendo tanto na Terra como no Olimpo, tarefas se não díspares, ao menos deliberadas. Dentre elas, Érato (de Eros, amor) responsável pela poesia lírica ou anacreôntica, jovem ninfa vivaz e gracejadora, coroada de murta e de rosas, trazendo na mão esquerda uma lira e na direita, um arco e tendo perto de si um pequeno amor e, às vezes, rolinhas que lhe beijam os pés. O autor ainda menciona Calíope (nome grego composto que significa um belo rosto), musa da poesia heróica e da grande eloquência, caracterizada como uma rapariga de ar admirável, encimada com uma coroa de ouro, símbolo que, segundo Hesíodo, representa a soberania perante as demais, além de ser adornada de guirlandas e trazer em uma das mãos uma trombeta e na outra, um poema épico, bem como de ser, conforme o consenso dos poetas, a mãe de Orfeu. Commelin ainda elucida o fato de que os banquetes não eram feitos sem a sua invocação e saudação com a taça na mão, tendo na figura dos poetas os que mais as enalteceram, sempre as invocando no início de seus poemas ${ }^{18}$.

Considerando a relevância das Musas para os poetas, como uma espécie de elucidação do fazer poético tecedor do Divino, observa-se que o flâneur-poeta, pela Paidéia Poética, similarmente, utiliza-se do sagrado para tessitura das polis excelentes ou da metáfora do grande poema épico de almanaque, tendo nos santos, signos, astros e astrólogos, uma sorte de representação de tais entidades, fazendo-lhes banquetes de exaltação, fartos de literatura e de outras artes, de elixires de longevidade, de vinhos, além de ambrosias e de receitas de felicidade, para o deleite dos habitantes das urbes quiméricas que, por sua vez, também realizam tais reverências, tanto no culto ao Belo, como na adoração diária dos representantes do sagrado, bem como na mesa farta de almanaquias.

18 . Commelin, P. Mitologia Grega e Romana. São Paulo: Martins Fontes, 1997, pp. 77, 78 e 79. 
É, pois, na volta à Antiguidade, considerando a função pedagógica e educadora dos poetas, que se menciona um texto assaz importante para representação do fazer poético como formação tanto da alma quanto do espírito para o Sublime, revelando aos leitores a falsa ordenação ou aparente tranquilidade da chamada Belle Époque, L'Initiation Poétique da sessão Ve Partie: Littérature do Almanch Hachette para o Ano de 1911. É pela Paidéia Poética que o flâneur-poeta, em consonância com o microcosmo místico-poético de almanaque, resume e resgata uma espécie de Arte Poética salvadora da civilização do utilitarismo circundante, com uma súmula, de autoria de Gourmont, das características do gênero, para então, resgatá-lo do aviltamento moderno. Ora, a Iniciação Poética principia com um excerto um tanto quanto significativo, posto que é a própria denúncia de que a sociedade moderna olvidou a importância da Poiésis, "On avait cru que les poètes, dans notre civilisation utilitaire, auraient une place de plus en plus réduite. Or, jamais peut-être ils n'ont fait tant de bruit par leur talent, leur nombre ou leur activité. Il faut donc connaître, ne fût-ce que sommairement, les principes et quelques exemples de leur art, afin de les mieux juger, et prendre plus de plaîsir à leurs oeuvres. De là cette brève Initiation poétique". Nessa, nota-se a elucidação de que os poetas perdem cada vez mais seu espaço na civiliação utilitária, malgrado sua criação nunca tão profícua proveniente de seu talento e de sua atividade. Como solução para tal problemática, a pedagogia poética atenta os leitores de que devem conhecer ao menos sumariamente os princípios e alguns exemplos dessa arte a fim de melhor julgar e contemplar as obras de tais criadores, bem como de serem curados da ignorância que os impede de alcançar o Belo. Logo, para sair da caverna e conhecer a Verdade pelo fazer poético, o texto começa com uma espécie de exaltação do gênero, visto que o coloca como gerador da boa prosa, La bonne Prose dérive de la Poésie. Como elucidação de tal título, tem-se uma indagação, Qu'est-ce que la poésie?, respondida por meio da diferenciação essencial entre a poesia e a prosa que reside no ritmo. Ainda a menção ao fato de que a verdadeira poesia é uma música, sendo no começo das civilizações, inseparável do canto, o que contribuiu para que uma expressão permanecesse: o poeta canta. 


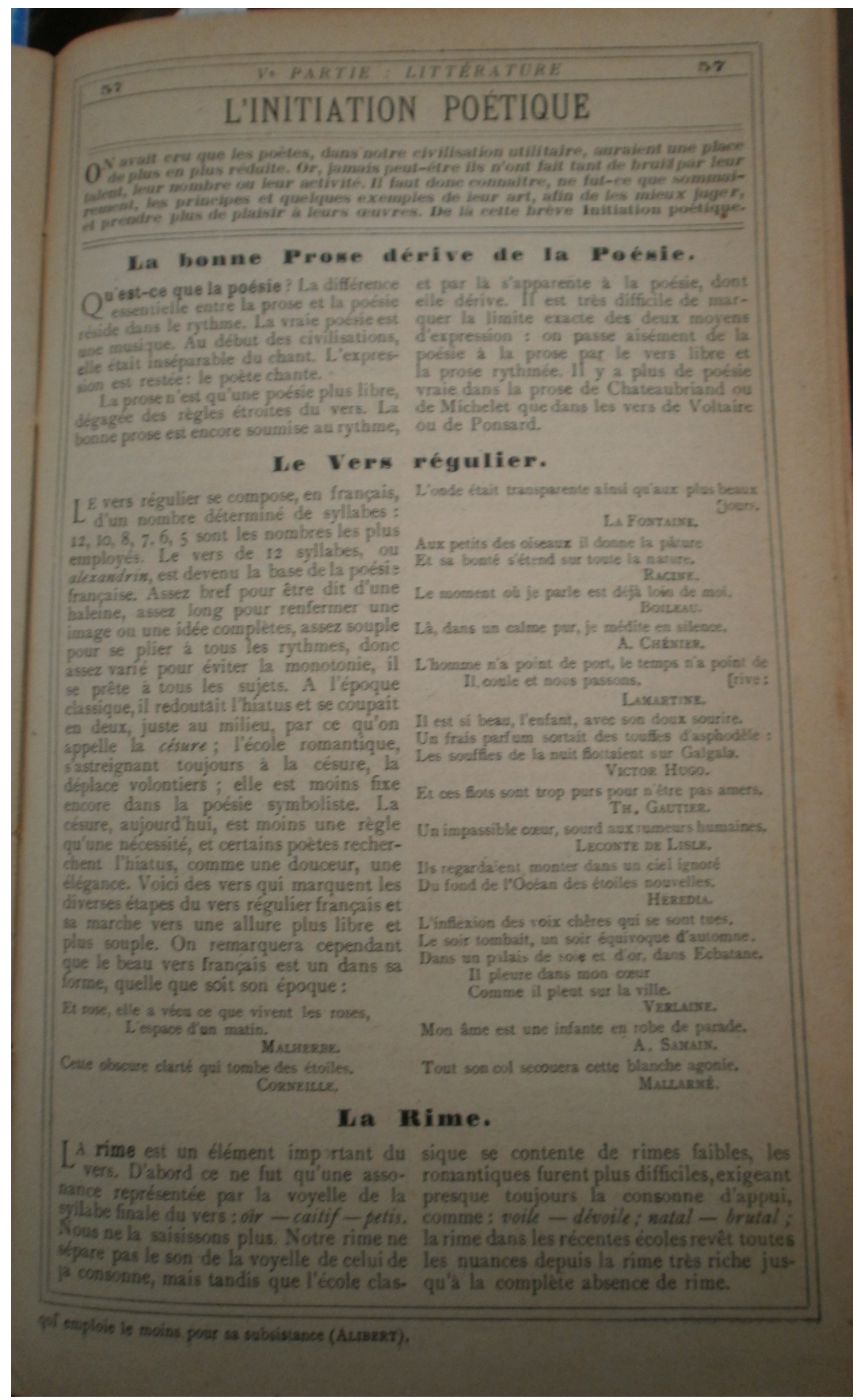

A explanação prossegue com alusão à prosa como poesia livre, isenta das regras estreitas do verso. Assim, a boa prosa é também submetida ao ritmo, e por isso, assemelha-se à poesia da qual procede, sendo muito difícil marcar o limite exato entre os dois meios de expressão. Nessa perspectiva, pode-se passar seguramente da poesia à prosa pelo verso livre e pela prosa ritmada. Tal proposição é aclarada com a menção de que há mais poesia verdadeira na prosa de Chateaubriand ou de Michelet que nos versos de Voltaire ou de Ponsard. O que se 
segue às considerações sobre a prosa é uma elucidação bastante didática sobre o verso regular, Le Vers régulier, que é composto, em francês, de um número determinado de sílabas: 12, 10, $8,7,6,5$ que são os mais empregados.

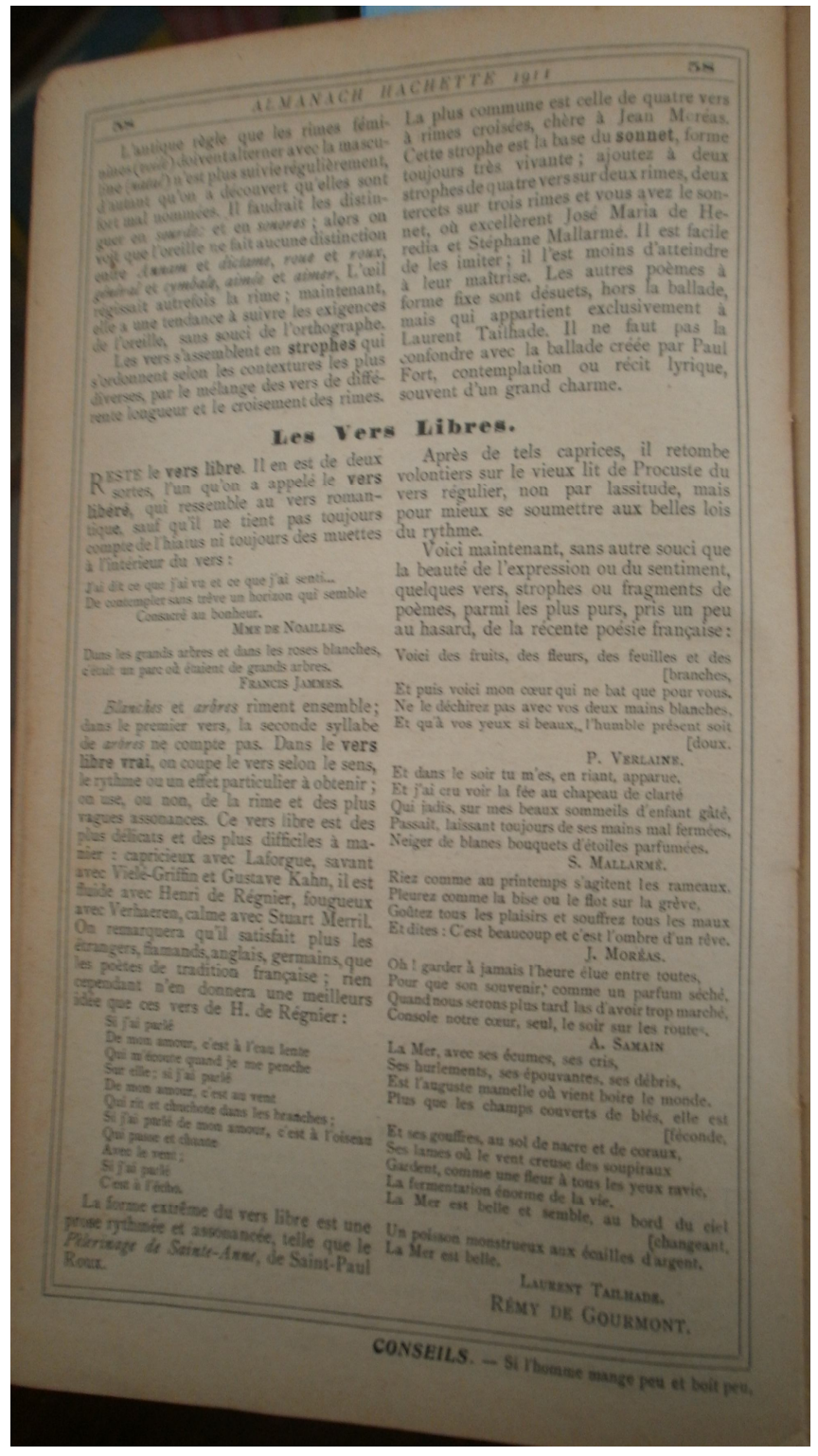

A rima moderna já não separa o som da vogal da consoante, enquanto que a escola clássica contentava-se com rimas fracas, sendo os românticos, os mais complexos, pois exigiam quase sempre a consoante de apoio, a ver: voile - dévoile; natal - brutal; o que nas escolas recentes dá-se por meio das rimas nas nuances as mais diversas, desde a mais rica até a sua completa ausência. $\mathrm{O}$ texto pedagógico acrescenta uma série de referências em ralação à rima, como a antiga regra das rimas femininas e masculinas, passando pela sua renomeação de surdas e sonoras, até chegar às estrofes, dentre as quais a mais comum é intitulada soneto, 
com menção a exemplos de autores. A didática para o Belo finaliza com informações sobre os versos livres, Les Vers Libres, que são de duas naturezas, aquela do verso libéré, que se assemelha ao verso romântico, apesar de nem sempre considerar o hiato e as sílabas mudas no interior do verso. Já no verso libre vrai, corta-se o verso de acordo com o sentido, o ritmo ou o efeito particular que se almeja, utiliza-se ou não a rima e vagas assonâncias. A pedagogia para regate do Belo, perdido em meio aos escombros da modernidade, finda com exemplos de autores que se servem dos versos livres e de outros apontados aleatoriamente para elucidação da beleza ou do sentimento da recente poesia francesa, com versos, estrofes ou fragmentos de poemas de Verlaine, Mallarmé, Moréas, Samain e Tailharde.

É por meio do texto educativo para resgate da Poiésis, que a Paidéia Poética salva os leitores dos almanaques da aparência enganadora da modernidade, a fim de livrá-los do estorvo que os impede de alcancar o Belo, fazendo das cidades excelentes, tecidas com o pincel do literário e as tintas de ouro do Eldorado, sítios representativos do próprio Sublime. Ora, é com a Iniciação Poética que se dá tanto a foramação dos leitores como sua cura, em doses homeopáticas, suplantando todos os degraus que os conduzem ao conhecimento da Verdade, para que após a terapêutica poética possam olhar diretamente para o sol, o próprio Divino incrito no Céu rebaixado ao chão do microcosmo de almanaque. É no resgate da Poiésis, que se observa uma espécie de retomada simbólica do poder das Musas como representação do misticismo-poético dos almanaques, fazendo dos deuses e heróis das epopéias antigas, também arquétipos dos leitores modernos, como se a mais alta arete, valorizada pelos primórdios, estivesse traduzida nas lições de poeticidade e de virtude do flâneur-poeta.

É, pois, na retomada da Poiésis olvidada no utilitarismo moderno, que o flâneur-poeta edifica suas cidades excelentes sob a égide das artes das Musas, tendo em seu poder de nomeação ou de desvelamento, a Criação salvadora do Caos da modernidade, cujos males são suprimidos pelo fazer artístico tecedor do Sublime. Essa tessitura poética, cujos fios de ouro em pó do Eldorado de almanaque são entrelaçados pelas artes, permite a construção das urbes quiméricas onde os leitores bebem da água do rio, não do esquecimento, mas da abertura para a conquista da Plenitude, direcionando à República de Platão, no momento em que amplia sua polis harmônica, enchendo-a com uma multidão de habitantes que complementam a edificação de sua cidade ideal, os caçadores e imitadores, que se utilizam de formas e cores, muitos que exercem o poder das Musas, poetas e seus ajudadores, rapsodos, atores, coreutas, empreiteiros e toda sorte de artífices, bem como uma maior quantidade de servidores. O 
diálogo prossegue com uma indagação elucidativa da relevância de pedagogos, amas, governantas, camareiras, barbeiros e também cozinheiros e açougueiros, além de porcariços, porcos ausentes na primeira cidade por falta de precisão e de outras espécies de animais para alimentação. Tendo em vista tal mudança, o diálogo entre Sócrates e Gláucon alude à importância do aumento do território e do número de médicos ${ }^{19}$. Considerando tal passagem, observa-se a superação da antiga querela entre poetas e filósofos, bem como da velha menção à supressão das artes da urbe platônica, posto que a presença dos actantes do fazer artístico, como responsáveis pela completude da edificação da polis excelente, demonstra que o alcance do Sublime depende de seus atos criadores, remetendo ao caleidoscópio poético de almanaque que tem nas artes o caminho tecedor do Divino. Ora, se a presença dos "imitadores" colabora para o acabamento da cidade ideal, é mister elucidar a importância da poesia e da música, as artes das musas na cultura grega, como auxiliadoras do desenvolvimento das virtudes a fim de atingir a Verdade, que Platão, segundo Rogue, considera como nocivas à edificação da urbe dos homens, apenas quando aprisionam ao mundo sensível. Não é a arte mesclada a contéudos utilitaristas modernos de que também fala o delator da desordem ocultada, o flâneur-poeta, tampouco sua obliteração oriunda de tal atmosfera fetichizada, mas sim o resgate de suas origens, aquela que o autor chama de arte vidente rimbaudiana [voyant], que segundo Vítor Hugo, permite ao poeta ver além da representação da realidade. Rogue considera a arte como justa quando se mostra deveras límpida a ponto de permitir que o divino cintile sobre nós, fazendo com que o artista seja encoberto por sua obra, a qual constitui a porta aberta para o mundo inteligível. É essa arte que o autor menciona como consentida por Platão, cuja mais alta arete carece desvanecer para deixar transluzir o ser verdadeiro. Ainda elucida que a prática de tal arte torna-nos videntes, permitindo-nos intuir a existência do sol inteligível que clarifica a realidade da qual a falsa aparência é apenas um reflexo, fazendo-nos erguer a cabeça para exercitar uma astronomia divinatória ${ }^{20}$.

Essa arte que permite alcançar o Sublime é praticada nas lições indicadas pela Paidéia Poética, fazendo das cidades excelentes, Paris e Rio de Janeiro, verdadeiros sítios tecidos pelas artes que salvam os leitores do mundo sensível moderno, como pedagogia de formação integral dos leitores, em que a ginástica para o corpo, representada pelo Método Desbonnet com seus diversos desdobramentos, e a música, como ginástica para a alma, em suas várias feições, permite o desenvolvimento dos entes para a conquista da Plenitude na Terra sem

19. República, 373 b, p. 68.

20 . Para melhor entendimento, ler Compreender Platão de Christophe Rogue, Rio de Janeiro: Editora Vozes, 2011, p. 179. 
males de almanaque. Em meio às artes tecidas nas páginas de almanaque, a música, que tem função privilegiada na educação platônica da polis harmônica, mas elucidada como uma dentre as outras que tece, concomitantemente, o céu rebaixado ao chão de almanaquias, é uma sorte de auxiliadora do processo de Criação poética, a cada edição anual, como alcance do Divino. Nessa perspectiva, tem-se os diferentes teatros e suas respectivas peças e concertos indicados nas páginas dos almanaques franceses e brasileiros, fazendo do canto do flâneurpoeta, mesclado à enunciação poética e ao universo da música do microcosmo quimérico, a melodia que embala e desenvolve os leitores para o conhecimento da Verdade. É, pois, na denúncia do aviltamento da Poiésis, que se observa o resgate da poética ab origine, tendo na tradição oral - o canto acompanhado pela musicalidade dos instrumentos e dos sítios representativos da sinfonia - a recuperação do sonhar com o melhor dos mundos possíveis no microcosmo de almanaque. Essa oralidade observada no canto do flâneur-poeta, inscrito no ritmo poético oriundo da concatenação das diferentes sessões de almanaque, remete ainda ao aspecto musical em suas diferentes representações, bem como à diégesis oral inata a tais livros herméticos, que muitas vezes eram lidos em grupos por apenas um indivíduo, devido à baixa instrução ou como fomento para a poeticidade e para a narração de verdadeiros causos que, por sua vez, eram recontados de geração a geração.

Dessa oralidade advinda de uma poética tecedora do Sublime, elucida-se a função da Paidéia de almanaque na formação dos leitores para as artes nas cidades excelentes, com a indicação no Almanach Hachette para o ano de 1911, de teatros, o Ópéra, o Athénée e o Gymnase, dentre os muitos indicados na sessão Les Théâtres de Paris, o que direciona à valorização do fazer artístico para a edificação da urbe perfeita, semelhante a Platão, cujos efeitos sobre a alma dos habitantes pode ou não colaborar para a conquista da harmonia caracterizadora da alma justa, de acordo com a arte praticada para desvelamento da verdade, que se traduz como o viés condutor do Divino. É com as lições das artes das Musas, em consonância com a misticidade de tais livros herméticos, que o aedo, flâneur-poeta, salva os leitores dos males da modernidade por meio de seu canto, fazendo de seu ato poético, a nova Criação, pelo poder da palavra, a geração das sessões de almanaque e a presentificação dos fatos passados e futuros, tendo os leitores a certeza de que a idade de ouro é recuperada, o presente resguardado e o porvir assegurado pelas diferentes representações do Divino, os santos, os signos, os astros, os homens dotados de poderes prodigiosos. Como na poética hesiódica, em que Hesíodo apreende o canto com as Musas quando pastoreava ovelhas ao pé do Hélicon, onde recebe um ramo que lhe inspira um canto divino glorificador do passado e 
do futuro (v. 25 - 35) $)^{21}$ É, pois, no canto do aedo, como metáfora da epopéia de almanaque, que nomeia e dá origem à cidade excelente, reforçado por seus diversos desdobramentos artísticos, que se elucidam os teatros como auxiliadores da pedagogia músico-poética que eleva os leitores ao encontro do Belo, a ver:

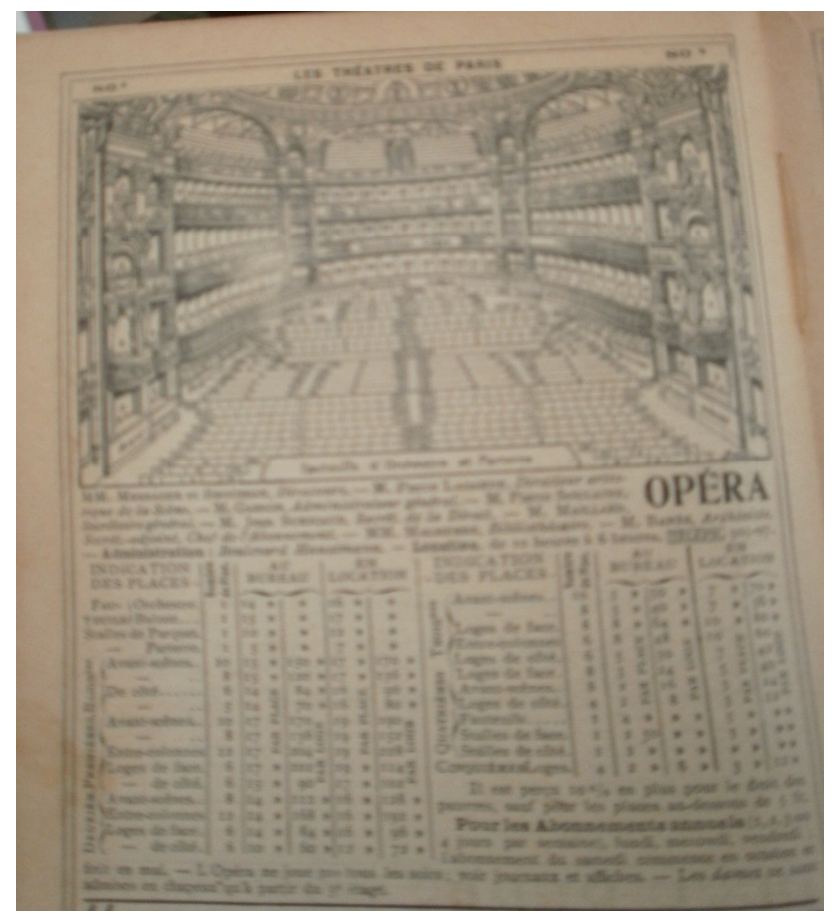

É pela Paidéia Poética que os leitores são instruídos para o Belo, fazendo das informações do Opéra, um tanto quanto didáticas, concernentes a preços, indicação de lugares, de horários, de seu corpo dirigente e administrativo, com um croqui assaz pedagógico no sentido de fazer conhecer o sítio antes mesmo de ali adentrar, o viés para a formação dos habitantes da polis excelente nas artes, em que uma espécie de mise-en-abyme poéticomusical é percebida e ouvida, posto que as sinfonias combinadas aos espetáculos estão inseridos no microcosmo poético repleto de oralidade que, por sua vez, é constituído pelo canto do aedo representativo do próprio Divino, como criador supremo e característico da melodia Sublime que embala o Universo do melhor dos mundos possíveis após sua geração. A educação pelo complexo artístico música, poesia, teatro contribui para a geração de uma espécie de cosmogonia ou teogonia poéticas, haja vista a presença marcante do sagrado em suas diversas representações, a cada edição dos almanaques. Esse poder de nomear e de dar

21 . Versos presentes na obra de Hesíodo, Teogonia A Origem dos Deuses, São Paulo: Iluminuras, 2003, p.107. 
forma ao Caos moderno, pelo flâneur-poeta, permite que as artes assumam o papel de auxiliadoras no processo de desenvolvimento dos habitantes das cidades ideais para o Sublime, como tecelãs do tapete quimérico que adorna o chão ou microcosmo Divino de almanaquias. Ora, é na fabricação anual de um novo Cosmo, pelo ato poético do aedo, que consideramos o teatro Athénée, cujo nome deveras sugestivo, permite o retorno às origens da Poiésis na antiga Grécia, que combinada à música, segundo Nunes, representa a união inseparável geradora do conceito de Kalokagathia (ser belo e bom), ideal pedagógico da sociedade grega do século V a.c. e adotado por Platão em sua República, orientando seus jovens para a prática dos exercícios gímnicos geradores da beleza estética e do cultivo das artes das musas a fim de atingir a beleza moral ${ }^{22}$, o que é visto de forma semelhante na Repú-

22 . Benedito Nunes. Introdução à Filosofia da Arte. São Paulo:Ática, 1989, p. 19. 

blica das delícias, posto que a Paidéia Poética educa seus leitores para o alcance da Plenitude. Ainda concernente ao vocábulo que dá nome ao teatro, Ateneu, salienta-se a volta à cultura grega, visto que tal nomenclatura representa um templo na Grécia antiga, edificado na cidade de Atenas e consagrado ao culto da deusa Atena, sítio reservado a reuniões de filósofos e oradores do período. Tendo em vista tal contexto, tal palavra também nomeou um escritor, Ateneu de Náucratis, cuja obra Deipnosofistas $O$ banquete dos eruditos remete às situações reservadas para o cultivo do corpo e do espírito, o que caracteriza a mesa farta de almanaquias com ambrosias, manjares e lições de cultivo, que livram os leitores, no microcosmo quimérico, dos males da modernidade. É, pois, no ato poético, de nomear, fabricar, produzir o Cosmo quimérico, que o flâneur-poeta recupera o passado antigo Sagrado, tendo no poder da palavra a mágica de presentificar pelo nome a coisa nomeada, ou seja, o templo antigo, onde se prestava culto à deusa Atena, e sítio de cultivo, tornam-se meio para alcance do Sublime como uma espécie de divinização salvadora do Tempo Profano moderno. É no teatro parisiense inserido no microcosmo místico-poético de almanaque, que os leitores podem simbolicamente prestar culto às divindades da Sabedoria traduzidas pelas representações do Divino e pelas lições de erudição de tal atmosfera hermética, tendo no ato mnemônico do cantar do poeta, a própria recuperação da idade de ouro hesiódica, cuja feitura primeira da Criação coincide com a geração do microcosmo de delícias. Ora, é na palavra cantada, o ato criador em consonância com as inúmeras sinfonias orquestradas pelos instrumentos, vozes, ritmos e corpos coreografados de tal sítio artístico, que as artes das Musas combinadas à misticidade de almanaque pavimentam o caminho poético, cujos degraus ultrapassados a partir do desenvolvimento integral dos entes, levam ao encontro do Sublime nas cidades excelentes.

É na tessitura do mundo das maravilhas, das urbes ideais, que os leitores têm, pelo poder da palavra cantada, lida e ouvida cotidianamente, a capacidade de superar as distâncias espaciais e temporais do Tempo Profano, presentificando o in illo tempore em todas as fases de sua vida, como uma espécie de cura para os males modernos que trocaram o Sublime pelo utilitarismo. O recobrar o Divino nas ruas sagrado-poéticas do microcosmo de almanaque remete a mais um exemplo de sítio que permite o retorno à matriz original da Poiésis e, por conseguinte, ao sopro gerador e modelador do Caos, o teatro Gymnase, que também representa parte dos ensinamentos da Paidéia de almanaquias, onde os leitores podem adquirir o conhecimento que os conduz à Verdade. Logo, a lição da "disciplina do Belo" é 
ainda passada de maneira bastante elucidativa, utilizando-se da imagem para melhor explicitar o conteúdo tecedor do Sublime, um croqui informativo com a indicação das galerias, do foyer, do balcão, e de outros lugares com suas respectivas poltronas numeradas, como uma espécie de manual pedagógico de conhecimento e localização do ambiente antes mesmo de adentrálo. É na mimesis de tal sítio, com seus atos criadores derivados da beleza universal, de que fala Platão, tomados aqui como edificadores do próprio Belo, que os leitores ou espectadores podem apreender ou cultivar o espírito para o alcance do Sublime, fazendo da leitura ou da contemplação a preparação para habitar a polis excelente. É nessa perspectiva que as artes têm função privilegiada na edificação da urbe parisiense, tendo na poeticidade de todas elas a feitura do Divino, cujas especificidades representam as partes que formam o todo Supremo. Ora, é na conquista da Plenitude pelo poder da palavra cantada combinada às artes em tal microcosmo místico-poético, que se analisa a simbologia do nome dado ao teatro, gymnase, remetendo novamente aos sítios da Grécia antiga, os ginásios, onde os habitantes da polis cultivavam o corpo e o espírito para o desenvolvimento de sua integralidade, o que torna lisível a urbe excelente como extensão do mítico-sagrado que salva os leitores das problemáticas da modernidade. É essa volta simbólica aos tempos originários que faz do microcosmo de almanaque uma nova Criação, modelando a massa informe do Caos moderno por meio do ato poético, como uma espécie de hino às Musas modernas representadas pelos 


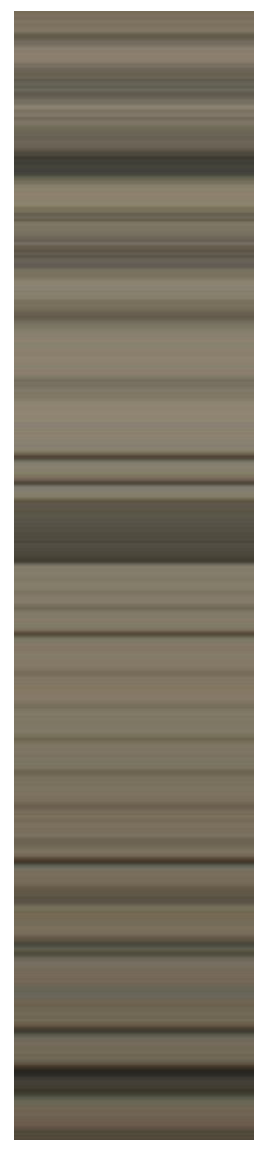

santos, astros, signos e astrólogos, cuja sacralidade salva os leitores do Tempo Profano e os conduz ao encontro do Sublime.

Semelhante ao almanaque brasileiro, apontam-se, no Almanach Hachette, várias referências à cultura grega antiga, cuja volta à matriz original da Poiésis é simbolizada já na capa do almanaque francês para o ano de 1911, que apresenta a deusa Atena destacada no centro, como emoldurada por uma suntuosidade de arabescos representativos da feitura do Belo, em meio aos meses do ano, com seus dias e seus respectivos santos. É, pois, no diálogo sagrado entre paganismo e cristianismo, bem como nas diversas representações do universo místico nas páginas de almanaque, que se elucida o ato poético como rememoração dos tempos originários e renovação da Criação, fazendo do microcosmo quimérico, o espaço divinizado e repleto de boa ventura característico da idade de ouro sem males. Ora, não é sem razão, que a deusa apareça centralizada na capa com sua nau ao fundo, antes da abertura da cortina sagrada que encobre o próprio Sublime nas sessões tecidas com os fios de poeticidade de almanaquias, o que remete à própria representação da divindade, que segundo Commelin, era filha de Júpiter e deusa da sabedoria, da guerra, das ciências e das artes. O autor menciona 
ainda que era filha preferida do senhor do Olimpo, tendo-lhe conferido várias de suas competências supremas, como o espírito prognosticador, o poder de delonga, quando lhe aprazia, dos dias dos mortais, a oferta de felicidade após a morte, e tudo o que aprovava com um sinal da cabeça era indefectível e o que prenunciava acontecia de maneira certeira. Também conduz Ulisses em suas viagens, instrui as filhas de Pândaro na arte da supremacia dos trabalhos femininos, como a representação de flores e de combates em obras de tapeçaria, e é a própria a embelezar com suas mãos o manto de Juno. Ainda se tem a menção de que ela manda construir a nau dos Argonautas a partir de seu esboço, na qual coloca em sua proa o lenho falante, cortado na floresta de Dodona e orientador dos navegantes, que tem função de atentar para os perigos e apontar meios para evadi-los. O autor cita que muitas cidades colocaram-se sob a proteção da deusa, no entanto a privilegiada foi Atenas que recebeu seu nome, onde eram feitos os cultos de veneração à divindade, com seus altares, suas mais belas estátuas, suas festas imponentes, além da edificação de um templo suntuoso em seu tributo, o Partenon $^{23}$.

23. Commelin, 1926, pp. 27 e 28. 


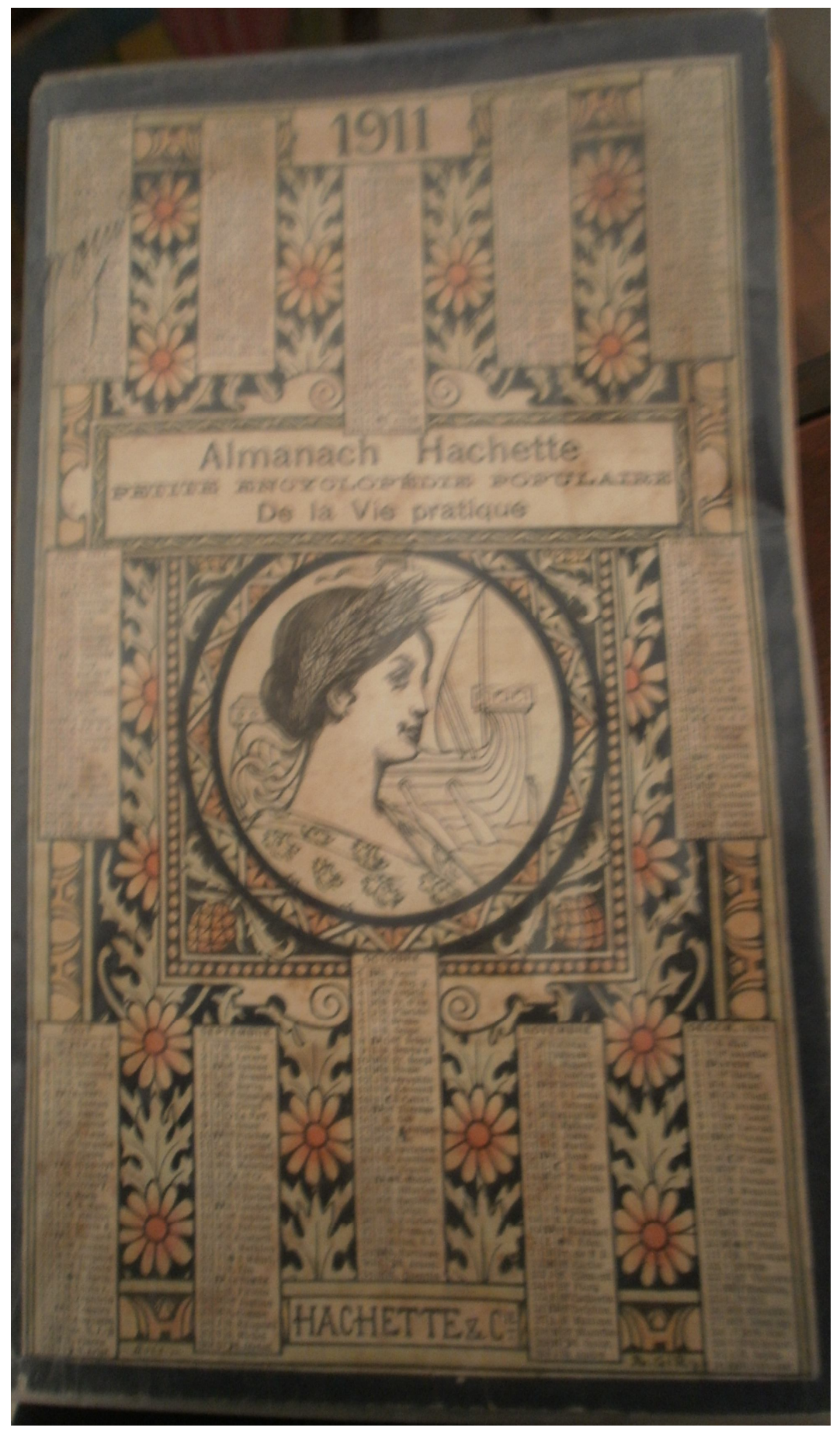

Considerando a simbologia da deusa Atena como entidade do cultivo, das artes e das ciências, é mister inferir a respeito de sua função de orientação dos leitores, posto que ao ser apresentada na capa de tal livro hermético - como uma espécie de guia da existência, cujo leme, em consonância com os representantes do divino nos almanaques, é governado para a conquista do melhor dos mundos possíveis, a cidade excelente, - salienta-se seu atributo de 
sabedoria também caracterizador da Petite Encyclopédie Populaire de la Vie pratique, o Almanach Hachette. É, pois, combinada à misticidade-poética de almanaque, que se nota a presença das prerrogativas supremas da deusa nos emissários do sagrado de tais livros, posto que seu dom de profecia é percebido nos homens dotados de poderes sobrenaturais que receitam bálsamos para uma vida repleta de Ventura. Ainda em sua faculdade de prolongar os dias dos mortais, a equivalência da longevidade garantida pelos elixires e outras receitas combativas da finitude, além da capacidade de proporcionar a felicidade após a morte que se traduz na Paidéia cotidiana para o bem morrer, com a proteção do sagrado que assegura um porvir em uma espécie de Hades de prazeres, a própria continuação da República das delícias. Se conduz Ulisses em suas viagens, tem-se a correspondência do bom curso, resguardado das intempéries da modernidade pela nau de almanaquias de deleites, até o alcance do Sublime na polis quimérica. Também na correlação com a arte na supremacia dos trabalhos dirigidos às mulheres que a divindade ensina às filhas de Pândaro, a semelhança na Paidéia Poética direcionada ao público leitor feminino dos almanaques, com os cuidados às que vêm a ser mãe, as recomendações na administração do lar em todos os seus âmbitos, bem como de indicações para toalete e para beleza, desde cremes a vestuário.

Tendo em vista a riqueza simbólica da deusa, em consonância com o microcosmo místico-poético de almanaque, tomam-se a divindade e os outros representates do sagrado, como condutores na aquisição do conhecimento libertador da ignorância que impede o alcance da Verdade, cuja Paidéia Poética diária, com suas lições infindas, ministra a pedagogia do Belo traduzida nas artes apresentadas e cultivadas no cotidiano das cidades excelentes. Essa educação para a beleza olvidada pelo utilitarismo da modernidade é retomada nas ruas poéticas da urbe harmônica, seja em instituições responsáveis pelo conhecimento, seja na própria poeticidade que se inscreve na atmosfera encantatória dos "pequeninos nadas" bandeirianos ou nas almanaquias para deleite tecedoras do Sublime.

É pela presença marcante das artes, que ao flanar pelas ruas das cidades excelentes, folheando as páginas dos almanaques, os leitores deparam-se com uma infinidade estética incentivadora do fazer artístico e do desenvolvimento do gosto, como uma espécie de hino às Musas cantado e composto com a melodia conjunta dos gêneros tecedores do Belo, tendo na misticidade de tal microcosmo poético a própria representação do canto litúrgico da nova Criação. É, pois, embalado pela sinfonia sagrado-poética dos espetáculos de circo e de dança, das óperas, dos musicais, dos concertos e pela própria oralidade oriunda da poeticidade da palavra cantada do aedo, flâneur-poeta, nas polis harmônicas, que se acrescenta a educação 
pela música na oferta publicitária e, concomitantemente, pedagógica dos instrumentos musicais. Nessa perspectiva destaca-se o anúncio da fábrica de acordeões alemã, da cidade de Klingenthal, Fabrique d'accordéons Wolf \& Comp., com 7000 funcionários e serviço postal no próprio estabelecimento, de onde se enviam diretamente os instrumentos, sem taxas adicionais de serviços terceirizados, prática apresentada, pelo discurso, como vantajosa, Envoi direct avantageux de La Fabrique. Além da garantia de se tratar de uma aquisição proveitosa, o enunciador ainda apresenta uma linguagem um tanto persuasiva concernente à prioridade reservada aos franceses, com um tom amistoso que coloca os clientes/leitores como preferidos em detrimento dos demais, isentando-os de qualquer tributo, Pour la France, en franchise de droit!. Ainda reforça a proficuidade do produto apresentando a vasta oferta de modelos de acordeão, 300 tipos, 300 Modèles d'Accordéons, o que assegura o leque de opção para uma boa escolha, que malgrado tamanha seleção, há garantia de devolução do instrumento caso não agrade o comprador e reembolso do valor despendido. A confiabilidade dos instrumentos é ainda salientada pela própria notoriedade da cidade germânica no tocante a sua fabricação, bem como pelas inúmeras atestações recebidas, e acrescida de algo prodigioso concernente ao aprendizado musical, a oferta do autodidatismo pelo método enviado gratuitamente. $\mathrm{O}$ discurso persuatório complementa a idéia de importância e distinção no mercado musical, ao elucidar que a fábrica não produz apenas os 300 modelos de acordeão, mas sim uma infinidade de outros instrumentos, como bandonions, concertinas, harmonicas, ocarinas, violões, guitarras, mandolines, cítaras, instrumentos de sopro, gramophones, dentre outros.

O enunciador finaliza legitimando a singularidade do estabelecimento no tocante aos preços baixos, Prix Modérés, bem como na minúcia, representativa de uma espécie de esmero para com os leitores/clientes, do envio gratuito de um catálogo magnífico em língua francesa, ou seja, o acesso ao método e ao encarte não apresenta o incoveniente da tradução do alemão para a língua materna, mas a facilidade do tornar-se um auto-didata pela pedagogia germânica advinda de um dos sítios mais consagrados na fabricação de instrumentos musicais.

É, pois, pela Paidéia poético-musical que o flâneur-poeta orienta os leitores para o Belo e alcance do Sublime no melhor dos mundos possíveis, cuja lição melódica, por meio do 
anúncio da fábrica de instrumentos alemã, tem a finalidade de educar os ouvidos para a sinfonia da palavra cantada do aedo que, por sua vez, vem acompanhada da cítara germânica e dos arranjos oriundos do aprendizado do método para o autodidatismo, em consonância com a harmonia do sagrado que ressoa nas ruas de ouro em pó da cidade excelente. Ora, a educação musical na urbe quimérica ultrapassa o didatismo moral da cultura grega do século V a. c., posto que ao retornar às origens da Poiésis, elucida-se a República das delícias como o próprio Belo resguardado de qualquer compromisso no que tange à índole humana, mas concomitantemente, reitera-se a representação da Verdade alcançada pelo fazer artístico. Logo, a Paidéia Poética rememora a pedagogia grega de desenvolvimento da mais alta arete na cidade ideal, na medida em que busca suprimir os males da modernidade pelo novo ato criador, no entanto conserva as artes em seu âmbito Sublime, protegido de qualquer finalidade que não seja a revelação da própria beleza caracterizadora do Divino.

Tendo em vista o Belo platônico concernente à música a que confia a estimulação das boas qualidades da alma, bem como a harmonia do Sagrado ressoada na polis excelente do microcosmo místico-poético de almanaque, que se elucida a proposição de Platão na República no que tange ao modelo de canto e de melodias na educação dos guardiões, cujo primeiro é constituído por três elementos, a palavra, a harmonia e o ritmo, e as subsequentes, pela ausência de choros e lamentações nos discursos, classificadas como harmonias chorosas. No diálogo, Gláucon é apresentado como músico e indagado por Sócrates a respeito das harmonias chorosas, que responde com a menção à mixolídia, à sintonolídia e a outras semelhantes a elas. O filósofo obtempera que tais harmonias devem ser extinguidas da educação pela música, posto que não servem nem mesmo às mulheres que devem trazer uma postura decente, muito menos aos homens, além de apontar a embriaguez como algo de mais nocivo aos guardiões, bem como a languidez e a ociosidade. Diante disso questiona sobre as harmonias lânguidas e adequadas aos banquetes, que prontamente acrescenta como as jônias e as lídias das quais se diz afeminadas, logo, suprimidas na educação de guerreiros. As essas harmonias seguem-se a dória e a frígia, que Socrates diz não conhecer, mas elucida a importância da harmonia que imitaria os tons e as modulações da voz de um homem valente, e a que representaria um homem em uma ação pacífica, sendo as que melhor descreveriam os sons da voz dos homens afortunados e infortunados, dos sábios e corajosos. Para tais cantos e melodias, há a menção de que não se fará mister a existência de instrumentos de muitas cordas e apropriados a todas as harmonias, mas aqueles produtores de maior número de sons, como a flauta, além da lira e da cítara na cidade, e nos campos, para os pastores, uma espécie 
de siringe. Com o intuito de legitimar e tranquilizar o músico diante de tal seleção, Sócrates menciona o fato de terem elegido os intrumentos de Apolo em detrimento dos de Mársias ${ }^{24}$.

Malgrado tal seleção didática de sons, melodias e instrumentos, é importante salientar que a música é o ponto nevrálgico da educação platônica, desde a mais tenra idade, além da poesia, que mesmo passando pelo crivo da triagem pedagógica, é imprescindível para a edificação da polis harmônica, o que leva a examinar a antiga proposição de que Platão suprime as artes de sua República, e que orienta para uma leitura semelhante para a construção da urbe quimérica de almanaque, salvo a distinção concernente à escolha poéticomusical, visto que nela a convergência das artes é preservada, sem o menor critério éticoseletivo. Ora, se na fabricação dos instrumentos pela elucidação platônica, preserva-se a feitura daqueles que produzem o maior número de sons, observa-se que na cidade excelente de almanaque há a oferta de uma gama de tipos e, consequentemente, de harmonias, que orquestram o canto sagrado ou a palavra cantada do aedo a cada Criação anual. É dessa forma que a Paidéia poético-musical orienta os leitores para o fazer artístico, como auxiliares da própria Criação, na medida em que os cultiva para uma espécie de colaboração na edificação e manutenção da harmonia litúrgica da polis excelente, traduzida simbolicamente pelo desafio à primeira geração cosmogônica caracterizada pelo repto de Mársias a Apolo, que segundo Commelin, é tido como o inventor da harmonia frígia, dotado de uma sabedoria insigne no âmbito da música, mas que foi vencido pelo deus, sendo amarrado em uma árvore e esfolado vivo por tamanha audácia. Diante de tal feito, Apolo arrepende-se e rompe as cordas da sua guitarra ou da sua lira e as deposita com as flautas de Mársias em uma caverna de Baco, a quem dedicou seus instrumentos ${ }^{25}$. É, pois, o ato poético caracterizado pela palavra cantada do aedo, flâneur-poeta, que representa tal desafio a cada nova edição dos almanaques, todavia não recebe a punição por seu atrevimento criacionista repleto de poeticidade, mas se torna a própria repetição e recuperação da sinfonia sagrada tocada $a b$ origene, pelos instrumentos ofertados entre as almanaquias para deleite, e que ecoa na nova idade de ouro moderna.

É pela Paidéia Poética que também se observa o cultivo das artes no Almanaque Brasileiro Garnier, posto que semelhante à cidade excelente parisiense, a carioca, Rio de Janeiro quimérico, orienta seus cidadãos-leitores para a estética do Belo, indicando uma série de teatros, em tal microcosmo hermético, para a contemplação da verdadeira beleza tecedora do Sublime no melhor dos mundos possíveis.

24. República, 398 c, d, e, 399 a, b, c, d, e, pp. 105, 106 e 107.

25. . Commelin, 1997, p.153. 
De forma similar, o flanar pelas ruas de ouro em pó da urbe perfeita brasileira, pelo folhear das páginas repletas de encantamento, também permite aos leitores o acesso ao canto poético do aedo, flâneur-poeta, soado tanto pela oralidade inata a tal livro hermético, quanto pelo ritmo construído a partir da concatenação das sessões de almanaque que, por sua vez, representam simbolicamente as estrofes de um poema maior, tendo nos teatros cariocas os sítios tecedores do fazer artístico, onde a sinfonia do sagrado é fomentada pelos diversos gêneros do Belo ali produzidos. É por meio da pedagogia estética que os leitores são educados para o alcance da Verdade, tendo no Theatro Municipal do Almanaque Brasileiro Garnier para o ano de 1911, o representante do lugar onde a feitura das artes é realizada a cada abertura da cortina, como metáfora da própria abertura do público para a estréia do Sublime na cidade excelente.

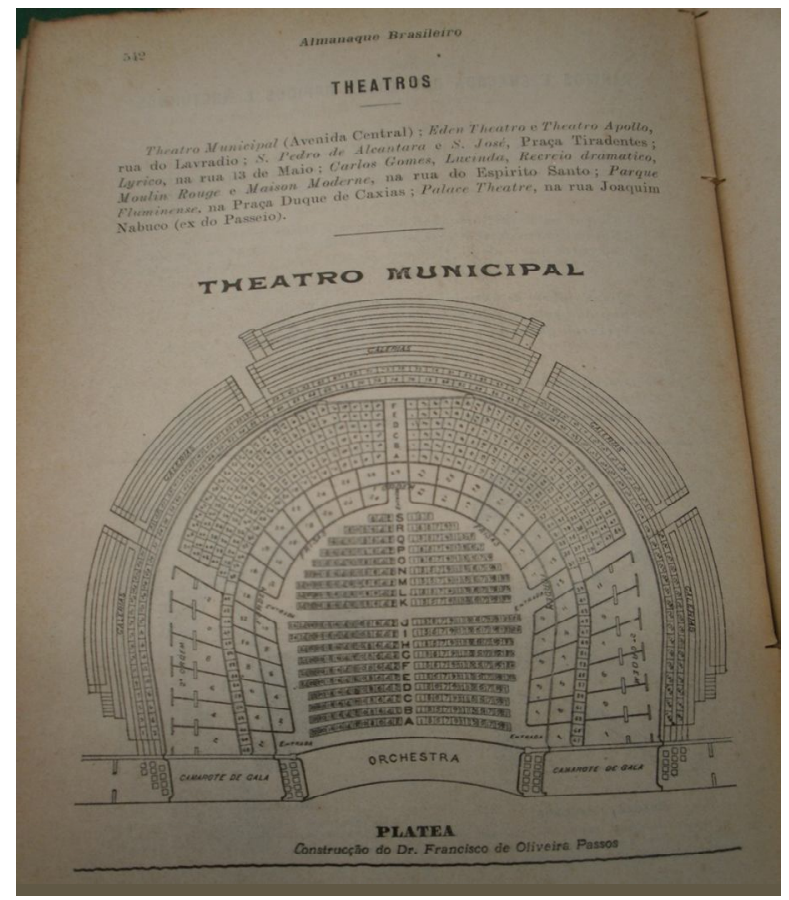

É na educação pelas artes, que os leitores têm uma seleção didática dos teatros e seus respectivos logradouros, o Theatro Municipal situado à Avenida Central, o Eden Theatro e o Theatro Apolo na Rua do Lavradio, o Moulin Rouge e a Maison Moderne na Rua do Espírito Santo, dentre outros. Antes de analisar a imagem do teatro, é necessário discorrer sobre alguns nomes sugestivos indicados na página em questão, como uma simbólica do próprio guia cultural, divulgador do Belo, da urbe ideal. Então, tem-se início pelo Eden Theatro, sítio, que segundo a simbologia do vocábulo Eden, remete ao âmbito do Sagrado em consonância com o microcosmo místico-poético de almanaque, ao Pays de Cocagne, ao Eldorado e a 
outros mitos representativos do lugar excelente, o que permite inferir sobre o diálogo com o Paraíso sem males da idade de ouro recuperada a cada edição, Criação, de tais livros herméticos. É, pois, em tal empírio artístico que se dá parte do processo de tessitura do Sublime, fazendo de sua sacralidade simbólica a própria representação do Divino, colaborando com a Paidéia Poética na educação dos leitores-plateia para o cultivo das artes e para o alcance do Belo na cidade excelente. A lisibilidade da polis harmônica dá-se em concordância com a leitura da plenitude advinda do teatro edênico, ou seja, o ato poético criacionista reflete simbolicamente esse tempo sem infortúnios de nenhuma ordem, cuja feitura divina reproduz a ordenação do Caos moderno em Cosmo maravilhoso pela Poiésis de almanaque.

Ainda sob o viés do Sagrado, passa-se à análise do Theatro Apolo, cujo vocábulo, de antemão, remete à simbologia caracterizadora do deus grego Apolo, reforçando a misticidade do microcosmo poético de almanaque e direcionando, pelo sítio promotor do Belo, novamente ao berço da Poiésis, semelhante ao Almanach Hachette. É nesse retorno simbólico à cultura grega, que se considera a divindade com suas diversas faculdades sagradas, posto que é o deus da música, como já mencionado, da poesia, da eloquência, da medicina, dos augúrios e das artes. Como Apolo desfruta da juventude eterna, o teatro inserido na cidade ideal, que leva o mesmo nome da entidade do sagrado, remete ao simbolismo das inúmeras ofertas de longevidade nas páginas dos almanaques, bem como do atributo do deus de exacerbada sabedoria nas artes e na medicina, o viés de produtor e facilitador do conhecimento de tais livros herméticos, além de dialogar com o caráter profético de seus representantes do divino e de seu próprio microcosmo prognosticador de ventura. Ora, como na análise dos teatros parisienses em que a rememoração da cultura grega permite a volta à idade de ouro hesiódica, nota-se que a sacralidade do Belo lisível tanto no sítio gerador de atos criadores quanto na cidade excelente, produz o alcance do Sublime pela supressão dos males da modernidade, por meio do ato poético ou da palavra cantada do aedo, flâneur-poeta, embalada simbolicamente pela lira de Apolo, que ao tocá-la embevece os deuses (representantes do sagrado) e dá harmonia ao canto litúrgico da Criação de almanaque.

É pela Paidéia Poética que os leitores dos almanaques recebem as lições diárias do Belo, o que remete à ponte quimérica entre as cidades excelentes, Paris e Rio de Janeiro, fomentadoras das artes, posto que os teatros brasileiros intitulados com nomes franceses, o Moulin Rouge e o Maison Moderne, apresentam o diálogo artístico entre as urbes ideais, fazendo do ato de nomear e rememorar tais sítios, a sua própria presentificação característica 
da chamada Belle Époque, tomada ainda como representação do intercâmbio de almanaquias para deleite que permitem o acesso ao Sublime em meio aos males do mundo moderno. É, pois, na lisibilidade das polis quiméricas que se nota a ausência simbólica das fronteiras que separam os dois países, cuja junção no único Pays de Cocagne representa a conquista do melhor dos mundos possíveis. É pelo ato poético do flâneur-poeta, tanto no almanaque brasileiro quanto no francês, que se dá a nova Criação traduzida pelo sítio maravilhoso sem perímetros reais, cuja Babel poética é posta simbolicamente ao chão, para dar lugar às passagens livres para sonhar nas ruas de ouro em pó representantes do próprio Divino na modernidade.

Logo, a educação pelas artes no microcosmo místico-poético de almanaque adota uma didática bastante elucidativa, visto que ao apresentar uma série de indicações de teatros com seus respectivos endereços, também apresenta plantas pedagógicas do Theatro Municipal supracitado, do Theatro Lucinda e do Theatro S. José, que fazem os leitores conhecer os sítios tecedores do Belo, sem ao menos adentrá-los, com a designação das entradas, das galerias, das frisas, dos camarotes de gala, da disposição da orquestra e da platéia com seus lugares indicados, bem como do próprio arquiteto responsável. Ora, é nesses lugares que os leitores são cultivados nas artes, tendo a cada espetáculo um degrau ultrapassado no que concerne ao caminho que leva à Verdade, como se ao invés de olhar o sol diretamente, o Sublime das cidades excelentes, tivessem que passar pelo estágio preparatório do Belo para a saída da caverna da modernidade.

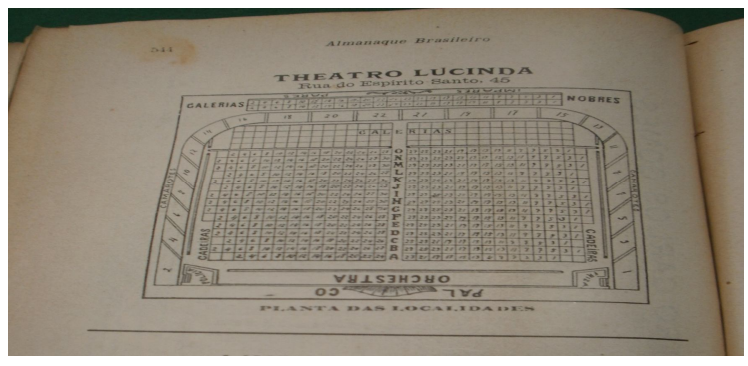




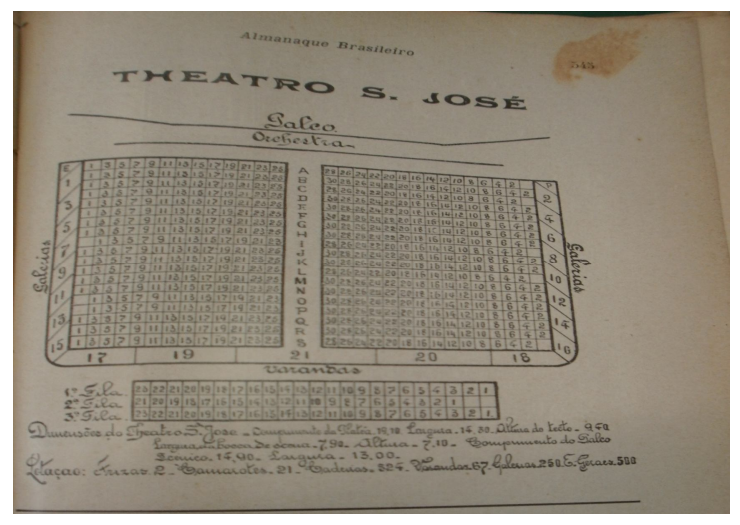

É, pois, em tais sítios tecedores do Belo, que se passa à Paidéia músico-poética já inciada nos espetáculos embalados pelos acordes que harmonizam a melodia da poeticidade na urbe ideal, ou melhor, o canto litúrgico representado pelo ato Criador de almanaque. A sinfonia sagrada tocada pelos intrumentos que acompanham o ritmo e a harmonia do canto poético do aedo, flâneur-poeta, na cidade excelente, e que aparece como uma espécie de pedagogia para o Belo, pode ser observada, como no Almanach Hachette, em uma propaganda da Fábrica de Harmoniums de manejo electrico, também alemã, mas da cidade de Neuenrade, do Almanaque Brasileiro Garnier para o ano de 1914. É pela oferta di-

dática do harmonium, como uma espécie de incentivo ao aprendizado da música, que observamos a elucidação das características do instrumento exibido na imagem, além de apresentar uma chamada um tanto quanto persuasiva, com a repetição da expressão "ultima novidade" por duas vezes, tendo ainda a informação de que tal inovação vem guarnecida de duas ordens de trombetas e de tubos de som. O discurso apresenta o harmonium de concerto dirigido a artistas, com um tom de consagração que enobrece o instrumento pela sua indicação à classe dos artífices do Belo, com trêmulo, vantagem em detrimento dos outros, sorte de efeito próprio que consiste na repetição acelerada da mesma nota, que imita o órgão da barberia italiana, e ainda o acompanhamento de jogo de guizos. É importante salientar que apesar da propaganda do instrumento ser de origem alemã, o brevet francês, n. 366798, reforça o diálogo Brasil-França aqui desenvolvido, posto que a intermediação dá-se pelo país 
com o qual se intercambeiam as almanaquias para deleite. É dessa forma que o discurso apresenta o valor do harmonium em franco, com uma espécie de redução a partir da data de divulgação, somente 11 fr. 90, bem como a informação de que possui 21 chaves e não apenas 19 como os demais, e outras referentes às características que fazem sua música assemelhar-se a de um orfeão, pequeno instrumento de corda e teclas. Com todos os atributos indicados, o enunciador informa os enunciatários do melhor dos mundos possíveis de que não há outra casa que produza tamanha sumidade no âmbito da fabricação de instrumentos, reforçando a idéia de exclusividade da fábrica alemã. Como legitimação de singularidade, o discurso aponta uma série de predicados do harmonium, ser ornado de três grandes tubos de sons e trombetas, como mostra a figura, pelo módico acréscimo de 2 francos e ter um jogo de guizos por mais 40 centimos. De forma semelhante ao Almanach Hachette, um método francês, para aprender a tocar o instrumento sem mestre, é enviado gratuitamente, com pagamento apenas da taxa de porte, 1 fr. 25 que, por sua vez, é recuperado por meio de reembolso, pelo recebimento do Magnifico Catalogo gratuito. $\mathrm{O}$ anúncio finaliza com a informação de que os leitores brasileiros podem adquirir os Harmoniums vienenses a 1, 2, 3 e 4 ordens, somente na casa do inventor, Robert Husberg, no logradouro, Neuenrade, n. 726, Alemanha.

Considerando a propaganda e tantas outras referências à educaçao pela música nos almanaques, que Platão privilegia em sua República, sendo nesse estudo um dentre os gêneros artísticos cultivados pela Paidéia Poética, que se observa uma espécie de pedagogia criadora, cujo papel traduz-se na formação dos leitores na arte do Belo, fazendo do retorno às origens da Poiésis o reencontro da tradição oral perdida, como o canto próprio da enunciação poética que, por sua vez, inscreve-se na palavra cantada do aedo, flâneur-poeta, acompanhada pelos instrumentos harmonizadores da melodia sagrada que ecoa na cidade excelente. É a partir da Iniciação Poética já mencionada, com lições para recuperação da Poiésis na modernidade, que se notam outras formas de orientação para o exercício das artes, como a indicação de partituras assaz didáticas, de quadros de diversos artistas, de concursos literários, de anos literários, de técnicas indicativas do progresso fotográfico, de teatros, de circos, de diversos instrumentos musicais, dentre outras. É, pois, a Paidéia Poética diária que orienta os leitores para a importância das artes, tendo com suas lições de autodidatismo o caminho para o desenvolvimento do gosto, cujo aprendizado de almanaque permite a cura dos engodos da falsa aparência moderna que impede o alcance do Belo.

É pela Paidéia Poética, resgatadora da verdadeira beleza do mundo, que se elucida o papel das artes na edificação das cidades excelentes, tendo nas propagandas analisadas das 
fábricas de instrumentos, a explicitação da relevância do cultivo pela música, posto que tanto no almanque brasileiro quanto no francês, a melodia e o ritmo da palavra cantada do aedo, flâneur-poeta, não são acompanhados simbolicamente pelas flautas de Mársias, mas pelos harmoniums, substituidores modernos, desenvolvidos pelos artífices, cujos acordes perfeitos harmonizam o canto litúrgico no microcosmo místico-poético de almanaque.

A palavra cantada ad infinitum nas cidades excelentes leva a considerar ainda a harmonia e o ritmo na construção da República de Platão, que privilegia os ritmos característicos do homem nobre e valente, fazendo com que a métrica e a melodia acompanhem a sua palavra e não que a sua palavra acompanhe a métrica e a melodia. O diálogo entre Glaucon e Sócrates segue na elucidação dos difrentes ritmos, com a menção de que isso será feito pela deliberação de Dâmon, a fim de conhecer os andamentos adequados à baixeza e à insolência ou à sandice e aos demais vícios, bem como dos ritmos reservados aos atributos opostos. A seleção dos ritmos prossegue no sentido de elencar de forma não muito acertiva alguns andamentos, como o enóplio, caracterizado como andamento composto, o dátilo e o heróico, de duração igual à batida e à elevação, levando-o a findar numa longa e numa breve. Ainda a apresentação do jambo, do troqueu, unindo longas e breves. Após explicitação dos andamentos, a tarefa é dirigida a Dâmon, posto que tal discussão demanda maior debate. Apesar do serviço destinado a Dámon, o diálogo prossegue caracterizando a boa elocução, a educação adequada, a harmonia apropriada, a graça e o bom ritmo como oriundos da boa índole. Diante disso, nota-se que a má postura e a ausência de ritmo e de harmonia são apresentadas como irmãs da má elocução e da má índole, ao passo que os predicados opostos são caracterizados como irmãos e imitações do contrário, o caráter do homem sábio e bom ${ }^{26}$.

É a partir da educação pelas artes nas cidades excelentes, incluindo a música, a palavra falada segundo Platão, o logos, que se faz uma leitura comparativa da genesis poética de almanaque traduzida pela palavra cantada do aedo, flâneur-poeta, com a palavra falada do Demiurgo platônico. Ora, é pelo canto do poeta no microcosmo de almanaque, que se infere a Criação como o rebento caracterizador do próprio Sublime, fazendo da massa informe, o Caos moderno, moldado pela Poiésis, a geração do Cosmo para sonhar, que na República de Platão, segundo Rogue, é o sol o rebento do Bem, caracterizando a origem da vida no mundo sensível na fonte do princípio supremo inteligível ${ }^{27}$. A propósito de tal feitura suprema, vale salientar ainda a elucidação de Nunes sobre a Póiesis, cuja densidade metafísica e cosmológica é

26. República, 400 c, e, 401 a, pp. 108 - 109

27 . Rogue, 2011, p. 144. 
constituinte de tal palavra, significando um produzir que dá forma, uma geração que organiza, ordena e produz uma realidade nova, um ente. $\mathrm{O}$ autor aponta a Criação segundo a concepção grega, apresentando a origem do universo advinda de um ato poético, cuja inteligência divina modela a matéria do estado de caos em realidade definida. Nunes ainda menciona que segundo a hipótese mítica de Platão, a gênese deu-se pela ação de um espírito sábio e elevado, o Demiurgo, que fez do universo a sua obra, o que os artistas rememoram ao conferir à matéria, uma forma precisa ${ }^{28}$. É, pois, no diálogo entre a palavra cantada e a palavra falada, o logos, no sentido de fabricação do ser, que se nota o canto poético como ato criador das urbes ideais, tendo na sabedoria do flâneur-poeta, inscrita na Paidéia, a faculdade de dar forma à matéria do estado de caos moderno, em uma realidade nova a cada edição de almanaque, como uma espécie de parto interminável em um devir poético.

De tal melodia criadora do Sagrado - combinada à música privilegiada tanto nos primeiros diálogos platônicos quanto nos tardios, como a própria harmonia absoluta do Divino e traduzida pela seleção dos andamentos supracitados, cuja seleção dos bons ritmos e das harmonias adequadas produz o acorde perfeito, - que se aponta a leitura análoga no sentido da genesis nas publicações anuais de almanaque, como a Criação pelo canto litúrgico representado pela sinfonia sacro-poética que harmoniza e reordena a própria realidade dos males modernos em natureza original nas ruas de ouro em pó das polis excelentes, inseridas no melhor dos mundos possíveis.

A Paidéia Poética que cultiva os leitores nas artes para o alcance do Sublime, também os orienta para os cuidados com o corpo, em uma espécie de reabilitação do físico para a conquista do Belo nas cidades excelentes, tendo na lisibilidade da polis harmônica na propaganda do Almanaque Brasileiro Garnier para o ano de 1907, da "Casa de Saude Dor Eiras" em Botafogo, a elucidação da terapêutica dos habitantes-pacientes que contribui para a edificação do microcosmo místico-poético de almanaque. Essa casa, ou melhor, uma das instituições de reabilitação, cuja máxima é a devolução de cidadãos virtuosos à cidade ideal, saudáveis e temperantes, possui uma série de atrativos para os doentes, em meio à vegetação, vistas para a bahia de Botafogo e, seguramente, em "sitio saudavel". A casa ainda assegura a inexistência de qualquer problemática concernente à recuperação, como encontrar um alienado em seus corredores, o que de fato é improvável pela eficiência do estabelecimento ao separar tais pessoas em lugares reservados para tratamento diferenciado. Ela certifica os pacientes de que existem duas partes Inteiramente Separadas, que não há motivos para

$28 \quad$. Nunes, 1989, p. 20. 
qualquer tipo de preocupação, sendo a ala dos dementes subdividida em pavilhões, com seções de eletricidade e duchas, a outra designada de Chalet Olinda, distante da primeira, para garantir a ordem e a aura de perfeição do estabelecimento. Para reforçar a idéia de confiabilidade, no final da propaganda, compreende-se que na parte dos pacientes com moléstias em geral, não se aceitam, em hipótese alguma, Alienados. É, pois, a poesia de almanaque, que salva os leitores das intempéries da vida, tendo na eficácia simbólica da casa de saúde, a salvação dos leitores-cidadãos das moléstias externas ao microcosmo perfeito, haja vista que na polis quimérica, os males são transformados em receitas para sonhar com o melhor dos mundos possíveis.

Tal sítio de cura é auxiliar da nova Criação, colaborando com a tessitura divina para o alcance da Plenitude, fazendo desse lugar reservado a tratamentos de ordem física e mental, a simbologia da volta à cultura grega antiga de cultivo do corpo e do espírito e, por conseguinte, às origens da Poiésis, onde se dá a conquista, na modernidade, da idade de ouro hesiódica perdida. Ora, é no retorno ao espírito helênico, que se considera o caráter do Sagrado no microcosmo místico-poético de almanaque, fazendo dos deuses patronos dos templos e de seus santuários, lugares reservados para o zelo do físico e da alma, a representação moderna na Casa de saúde do doutor Eiras, posto que sob os auspícios dos santos, dos astros, dos signos e dos áugures, os leitores têm a terapêutica simbólica para suas mazelas advindas de qualquer natureza.

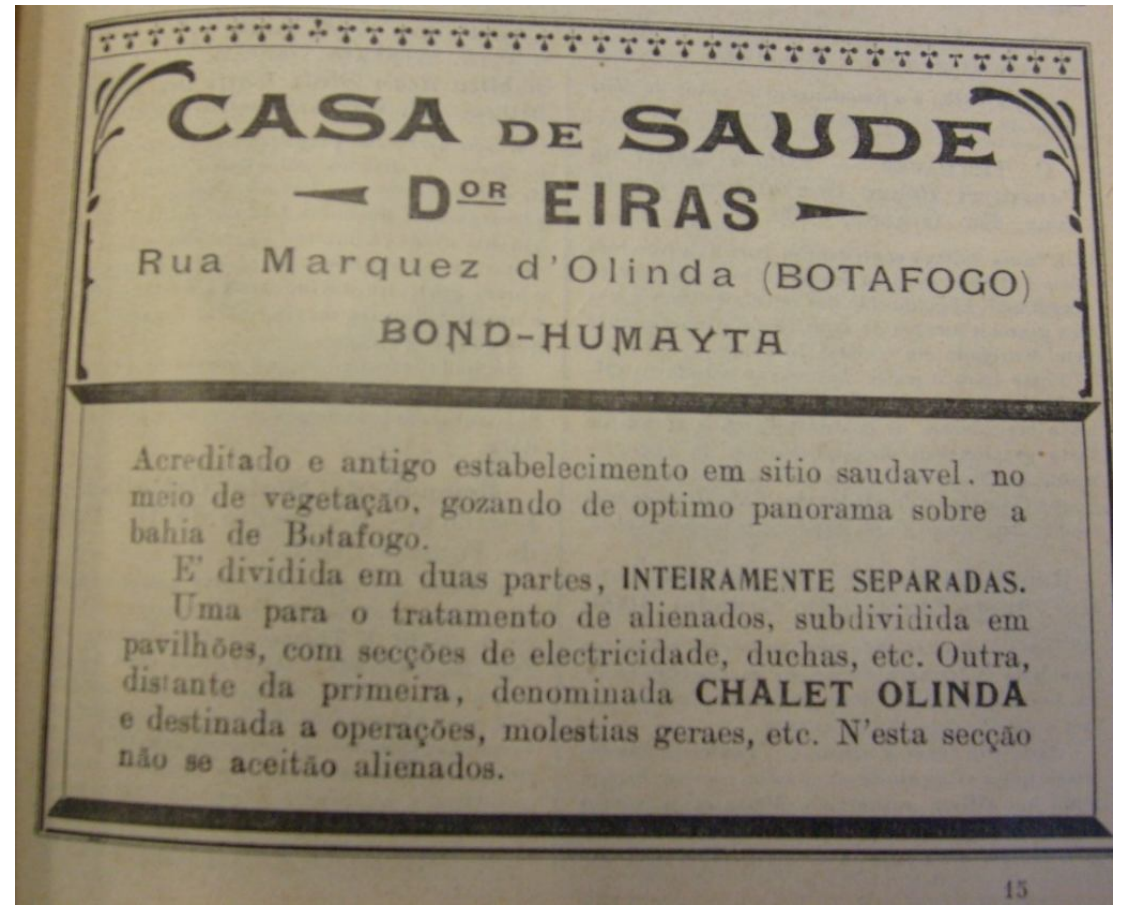


É a partir da gênese curativa geradora da nova realidade e dos novos seres, a urbe ideal com seus habitantes sadios, que se observa o ato poético como ordenação da matéria do estado de Caos, os cidadãos enfermos na cidade representante da desordem moderna, em Cosmo de almanaquias para deleite. O Demiurgo-poeta parte da cura, pela Poiésis, de seus entes imersos no universo caótico da modernidade, uma espécie de tratamento em doses homeopáticas para a saída da caverna - que segue primeiramente o conhecimento dos objetos representantes das imagens, para seguidamente enxergar apenas o reflexo do sol e por último poder vê-lo diretamente - como elucidação do próprio engendro da matéria bruta preexistente, o desordenado Rio de Janeiro e seus seres enfermos, em uma nova realidade, a cidade excelente povoada de habitantes sãos e sábios.

É o que se encontra de forma semelhante no Almanach Hachette para o ano de 1909, na Station de Cure Châtel-Guyon, uma das pérolas termais de Auvergne, um sítio também destinado a tratamento de moléstias e auxiliar na edificação da cidade ideal, Paris. Nesse paraíso perdido, as águas, das vinte e oito fontes, têm poder para curar moléstias de qualquer procedência. Logo, a cura inicia-se pela contemplação da exuberante natureza, além de seus cinco milhões de litros de águas termais das mais puras. Sendo um vale cercado, de um lado pela imensidão da fecunda Limagne, e do outro, pelo cinturão imponente e grandioso dos Monts Dômes, localiza-se em um admirável parque no qual se eleva a arquiteturas das grandes termas. Nesse recanto simbólico de milagres, onde as águas têm poderes prodigiosos, encontram-se diversos tratamentos para enfermidades em geral, desde banhos em água mineral corrente, passando pelo estabelecimento do doutor Henry, com os serviços de: Hydrothérapie, Massothérapie, Mécanothérapie, Électrothérapie, etc. 


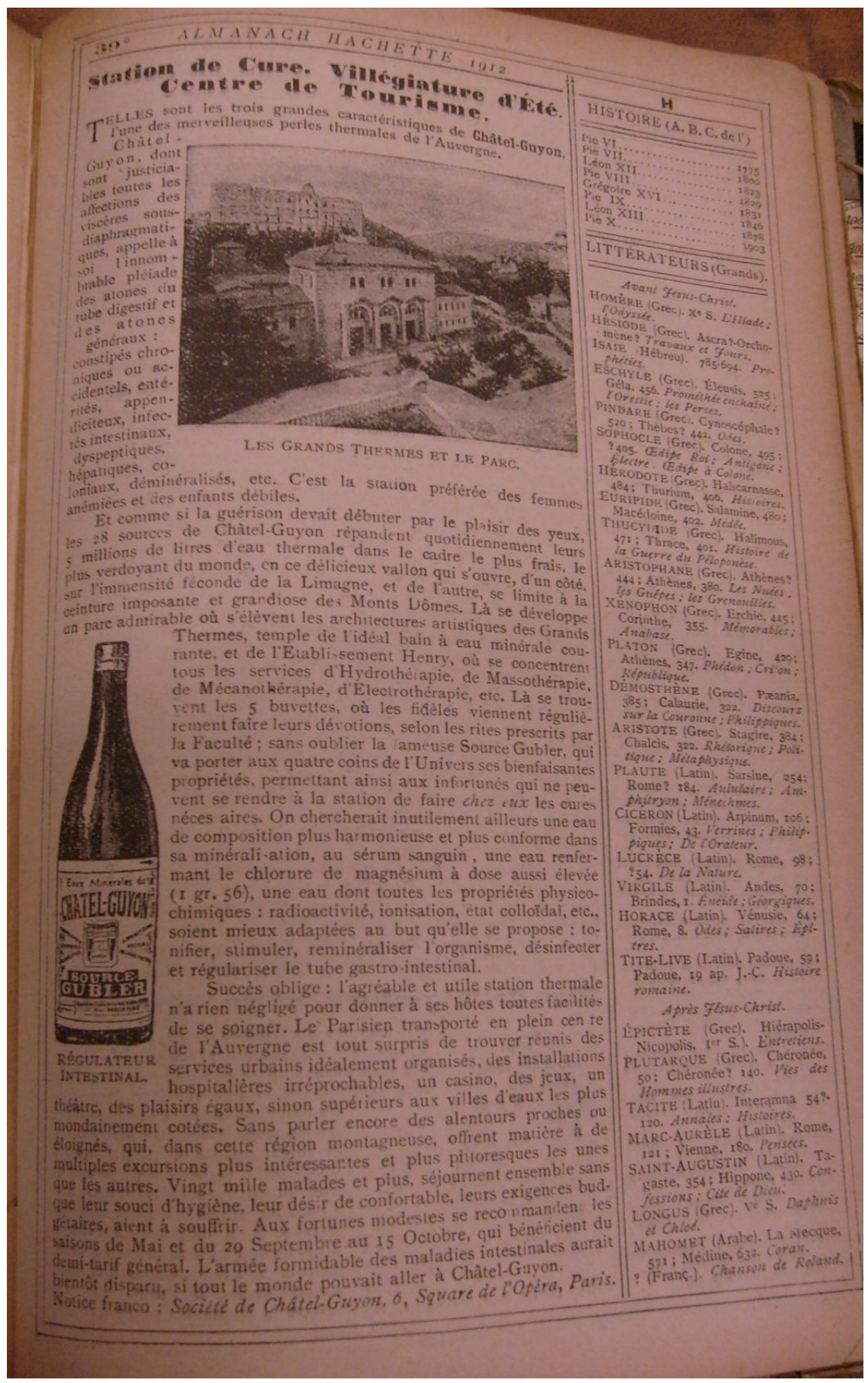

Além da vasta oferta de tratamentos para doenças, nota-se que a Station ChâtelGuyon ainda possui cinco fontes sagradas nas quais os fiéis vêm frequentemente fazer suas devoções, segundo ritos prescritos pela Faculté. Ora, observa-se que além do poder médicocientífico que a estação de tratamento assegura, ela está imersa em uma atmosfera de magia, na qual seguindo os rituais pré-estabelecidos a cura milagrosa é garantida: 
Nesse sentido, a linguagem simbólica do mito evocado no ritual mágico é muito mais eficiente do que a linguagem médico-científica. Saber, por exemplo, que a causa da doença que temos é um vírus não interfere na nossa possibilidade de cura. A relação micróbio-doença é exterior ao espírito do doente. Mas o conhecimento de que uma dor é causada pela intromissão de um espírito maléfico é fundamental no processo da cura mágica. (MONTERO, 1986, p.63)

Dessa forma, o tratamento na Station Châtel-Guyon vai além da simples utilização das águas e de seus serviços diversos, mas é fortalecido com o seu poder sagrado, combinado aos rituais prescritos. Como analisado no Almanaque Brasileiro Garnier, a questão da reserva de um sítio para o tratamento adequado dos doentes, também é visível no Almanch Hachette, ainda que não exista a segregação direta entre os alienados e os doentes em geral, reservando um local destinado à cura para as doenças da sociedade moderna, colaborando com o ato de dar forma à matéria preexistente, a cidade enferma, Paris. Além da preocupação com o corpo e com o espírito, dado os rituais prescritos, é interessante ressaltar a eficácia universal que tais águas apresentam, como a famosa Source Gubler que permite mesmo aos desafortunados, que não têm condições de ir até a estação, de fazer os rituais curativos na própria casa, "faire chez eux les cures nécessaires".

Não se pode deixar de mencionar o caráter de entretenimento da estação de tratamento, pois essa parece nada menos que um hotel ou pousada para turistas Centre de Tourisme, e não para doentes. Estando afastada, não em um centro urbano, onde há maior concentração de pessoas, mas em meio a um vale, a estação propricia simbolicamente o processo de fabricação, a partir da matéria desordenada moderna, da sanidade e da temperança características da nova Criação de almanaque. Além disso, destaca-se um tom de consagração no discurso concernente à estação, posto que o parisiense, cidadão de maior prestígio na sociedade da época, urbano e acostumado com todas as facilidades da cidade grande, pode confiar que mesmo no centro de Auvergne, desfrutará de toda infraestrutura de serviços plenamente organizada, services urbains idéalement organisés, com instalações hospitalares, cassino para distração dos doentes, teatro, excursões em lugares pitorescos e interessantes, haja vista a localização montanhosa do lugar, certificando o doente/leitor que seus serviços são equiparados, se não melhores, que os de muitas cidades que oferecem tais tratamentos.

Em tal sítio maravilhoso, a política da benevolência é o caminho indicado para atingir a arete traduzida pelas virtudes do melhor dos mundos possíveis, lisível na assistência aos doentes modestos, posto que o estabelecimento apresenta soluções até mesmo para os enfermos/leitores que, aux fortunes modestes, não podem frequentar a casa de saúde. Eles são 
orientados a fazer seu tratamento no período de maio ou de vinte de setembro a quinze de outubro, interregno que oferce meia tarifa, saisons de Mai et du 20 Septembre au 15 Octobre, qui bénéficient du demi-tarif général, ou seja, não perdendo de forma alguma, pacientes, quiçá por serem os meses menos procurados para tratamento, tendo a garantia de que a Station de Cure, Villégiature, d’Été não perderá, em nenhum momento, a sua função, de curar os males do corpo e da alma, ainda que a política do lucro esteja incrita como denúncia da massa caótica moderna, transformada em uma mais-valia às avessas, ou melhor, a do onirismo que cura os leitores da falsa aparência circundante. Logo, nenhum habitante da cidade ideal é privado da educação/tratamento que se dá por intermédio da Station de Cure, sendo ela responsável por tratar e devolver bons cidadãos à urbe dos sonhos, mesmo os que não possuem recurso para tal, garantindo que os seus vinte milhões de doentes convivam sem a mínima preocupação com a higiene, o conforto e as exigências orçamentárias, ou seja, é um verdadeiro santuário, acessível a todos, auxiliar do microcosmo místico-poético dos almanaques, de cura para todos os males.

Em se tratando da divisa sustentada pela Belle Époque, a joie de vivre, no contexto histórico em que são escritos tanto o Almanaque Brasileiro Garnier quanto o Almanach Hachette - cujo perído sustenta a leitura comparativa aqui desenvolvida, haja vista o forte diálogo entre a cultura francesa e a brasileira na época - transforma-se a busca dos ideais da idade de ouro, característicos da modernidade com seus incontáveis males, em um retorno às origens da Poiésis, fazendo da volta aos mitos, ritos e sonhos, a tessitura das cidades excelentes, Paris e Rio de Janeiro. Ora, se os males da modernidade não são suprimidos pelos ideais da chamada Belle Époque, tem-se na edificação das urbes dos sonhos, em consonância com o Cosmo e representante da nova Criação, a abertura para a verdadeira Beleza do mundo, no microcosmo que permite a aquisição de uma vida virtuosa, sábia e feliz:

\footnotetext{
Pressionado pelos interesses do capital internacional que exigia o controle das doenças tropicais, o governo assume como sua meta prioritária a bandeira do saneamento. Ao atrelar o projeto sanitário de Oswaldo Cruz ao projeto de reforma urbana, as autoridades públicas tentavam minimizar o caráter autoritário e repressivo das medidas modernizadoras. Em nome do saneamento científico e do progresso, a administração pública vai converter o espaço urbano em valiosa fonte de arrecadação de capital. (Velloso, 1987, p.11)
}

É o que se observa na Paidéia Poética dos almanaques brasileiros e franceses, na medida em que se utilizam de uma linguagem de salvação dos males vigentes, sejam eles de qualquer natureza. Nota-se, pois, uma série de orientações para que a higienização e o saneamento sejam prioridades nas cidades ideais, Paris e Rio de Janeiro, como delato do Caos moderno ideológico e parte do processo pedagógico-sagrado de modelagem, pela Poiésis, da 
massa informe e enferma. Desse modo, as orientações, ou melhor, uma espécie de Paidéia médico-poética é lisível nos almanaques pelos diversos modelos de higiene, como na seção $I V$ Partie: Médecine, Hygiène do Almanach Hachette para o ano de 1914, em que se apresentam dicas de como realizar a higiene bucal das crianças e conscientizá-las de que tal procedimento é imprescindível: Soignons les dents de nos enfants, Ce que toute Mère devrait savoir, Faut-il Soigner les Dents de Lait?, Habituez l'Enfant à Soigner ses Dents. O cuidado com a higiene infantil explicitado nos textos segue a política de progresso/civilidade e de assepsia da Belle Époque, a fim de combater a mortalidade desde a mais tenra idade e de educar futuros cidadãos com os pressupostos da mítica idade de ouro, projeto que é realizado verdadeiramente na cidade utópica do melhor dos mendos possíveis, com o alcance da justiça e das virtudes de seus cidadãos, por meio de uma poética que livra os leitores dos grilhões do mundo das aparências. É nessa perspectiva que Winock aborda as descobertas médicas em tal período, a imunologia e a microbiologia de Pasteur, alguns causadores de doenças graves entre 1880 e 1890, o bacilo da tuberculose pelo médico alemão Robert Kock em 1882. O autor ainda nos atenta para a lei de 1902 sobre higiene pública, medidas para limitar a propagação de germes patogênicos. Diante disso, a luta contra o micróbio é engajada, com o saneamento das cidades, a limpeza dos imóveis e os cursos de educação moral na escola elementar baseados nas necessidades de uma boa higiene para as crianças. Ainda cita que nesse período se começa a ler, nos compartimantos do metrô, "Défense de cracher". Tal política de higienização alerta os indivíduos sobre o fato de o inimigo ser invisível, sendo necessário combatê-lo com o poder público ${ }^{29}$.

Tal política de higiene pública é lisível no almanaque francês - como próprio ato denunciativo da desordem instaurada no Caos da modernidade - que, por sua vez, fornece às mães uma série de cuidados e informações quanto à dentição dos filhos, no entanto, convertida em orientação para alcançar a felicidade de viver na cidade quimérica, remetendonos ao mito de Paris, a representação da cidade grande, opulenta e mágica inscrita no imaginário de seus habitantes. É nessa mitização da cidade, que se considera a elucidação de Roger Caillois, ao mencionar a presença de uma poetização da civilização urbana, de uma adesão profunda à sensibilidade da cidade moderna, o que chama atenção para o fato de que tal fenômeno seja, possivelmente, consequência de uma revolução do espírito de outra época. É, pois, na tessitura poética da cidade ideal, com seus mitos passantes, que ainda se considera a menção do autor sobre a transfiguração da urbe em mito que, por sua vez, deve agir como

29 . Michel Winock. La Belle Époque (Paris: Perrin, 2007), p. 192 
tal, sendo suscetível de interpretação e reveladora de destinos ${ }^{30}$. É o que se observa na lisibilidade da grande cidade, ao tomá-la como um microcosmo onírico revelador do destino de seus habitantes, posto que em consonância com os astros, santos, prognosticadores, dentre outros, tem-se a segurança de uma Providência feliz.

Nessa cidade ideal que fornece receitas de ventura, tem-se ainda no início da quarta parte da seção, um discurso em que o enunciador aconselha as mães utilizando um tom de ressalva, posto que sua função na tarefa de educação da criança não pode ser, em hipótese alguma, negligenciada, comprometendo a boa formação de futuros cidadãos vistuosos. Logo, são instruídas para o cuidado dos dentes de seus filhos, sendo responsáveis pela sua higiene bucal, elucidando a relevância de tal prática, tendo-a como o sorriso do rosto "Les dents sont le sourire du visage", as pérolas da boca, cuja brancura indica nossa saúde, "Perles de la bouche, les dents blanches brillent de l'éclat de notre santê". Para isso, há no discurso, um imperativo, que na verdade tem poder de advertência, alertando-as a não descuidarem de suas atividades do lar, como ensinar os filhos a realizar a higiene bucal e a conservar os dentes, "Mères, apprenez de bonne heure a vos enfants à soigner leur bouche et à conserver leurs dents".

30 . Ver Roger Caillois. Le Mythe et l'homme. Paris: Gallimard, 2002, pp. 156 e 163. 


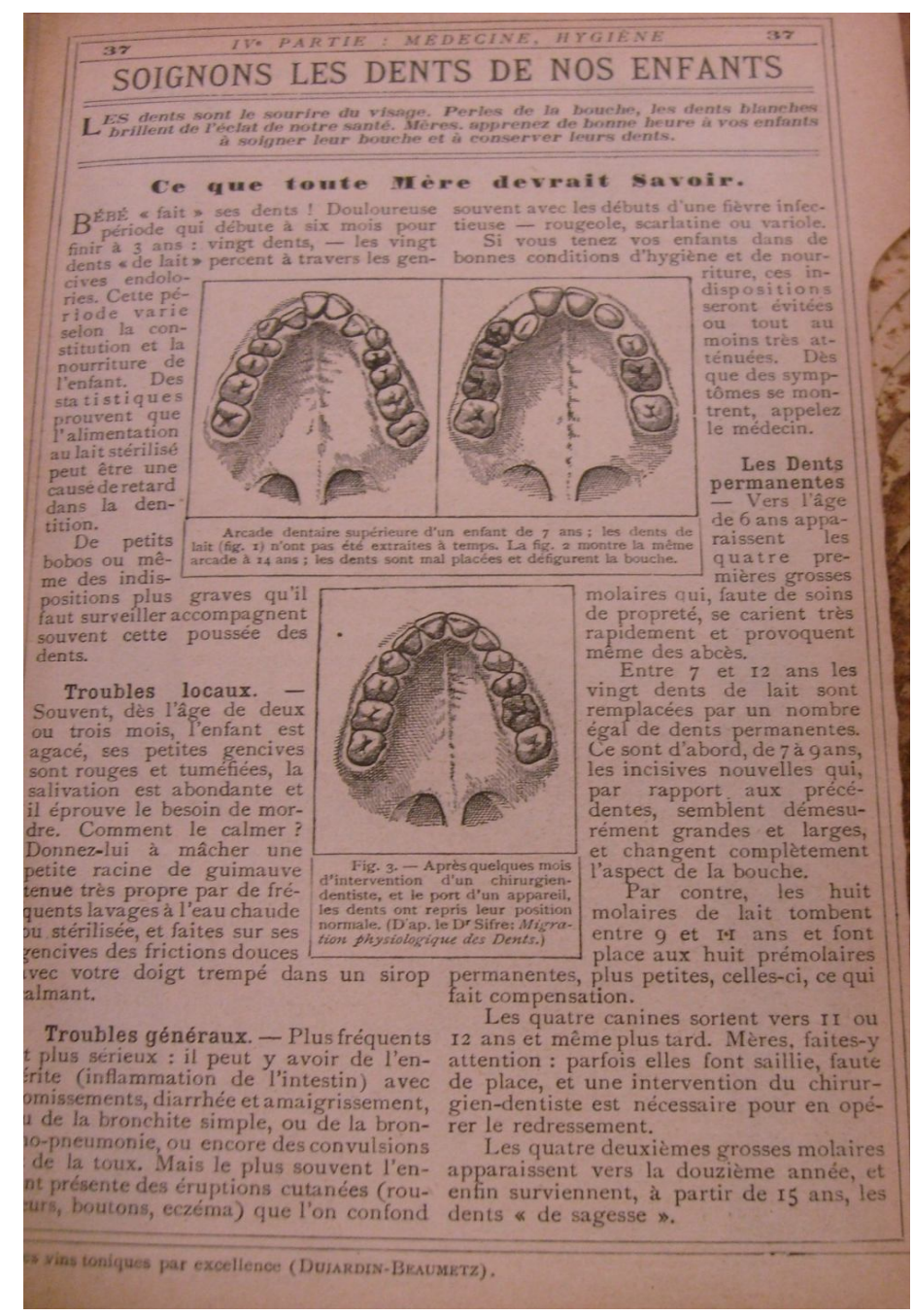

A mãe da chamada Belle Époque, o que é observado, tanto no almanaque brasileiro quanto no francês, tem o papel de ajudadora da política de manutenção do lar, por conseguinte, da preservação dos filhos, aqui lisível como orientação advinda da Paidéia Poética, sendo a miticidade a base para a verdadeira ordenação que permite sonhar na cidade excelente, tendo no ideal do viver bem, ministrado pelas lições de almanaque, o alcance das virtudes, pelo cultivo dos bons hábitos indicados, para alcance da plenitude na autêntica idade de ouro.

Nessa seção, a formação das genitoras quanto à higiene e ao conhecimento médico caminha lado a lado, pois elas têm uma série de informações quanto à constituição tanto da arcada superior quanto da inferior de uma criança, desde a mais tenra idade, de problemas bucais característicos de uma determinada fase ou da má alimentação, das particularidades dos dentes de leite e dos permanentes, o que vai ao encontro dos serviços de uma espécie de 
tira-dentes popular, aquele que trata da dentição a preço módico, o baixo valor pago na compra dos almanaques, rememorando a condição primeira de tais livros herméticos, a de atingir um vasto público, atualizando ainda os manuais de saúde da Bibliothèque Bleue e as edições correspondentes da literatura popular brasileira, que tinham nas preparações de remédios caseiros mescladas ao universo mágico e religioso a retomada da antiga harmonia universal que o microcosmo de almanaque resgata, na modernidade, pelo alcance do Sublime. É a popularização das informações, para tratamentos dentários no âmbito doméstico, que garante a equidade de acesso à saúde bucal por todos da República das delícias, como se na mascataria de almanaque a escova-de-dente saísse da hôtte, um dos artigos de mascatagem,

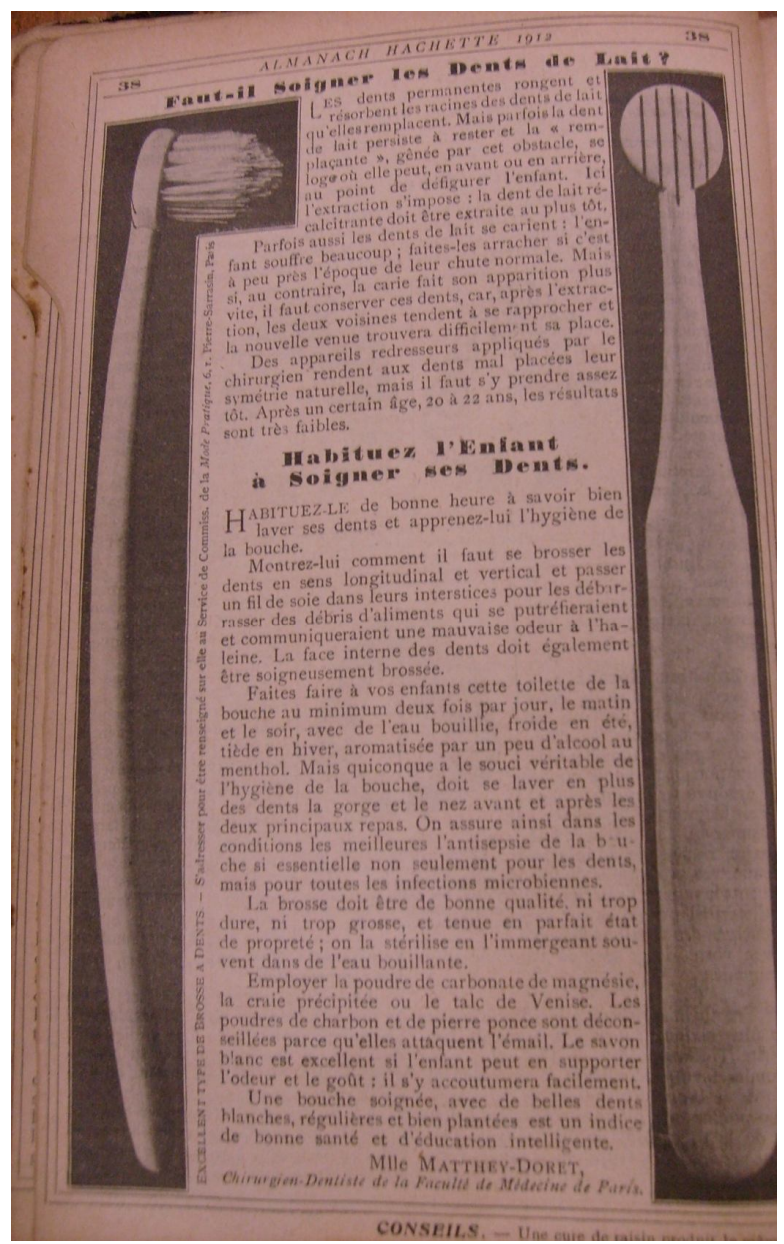

para limpeza das mazelas sociais, tendo na simbologia do comércio de porta a porta, a atualização do antigo serviço domiciliar para poucos, do dentista e do médico que iam até seus pacientes. É a própria mimesis da educação para as mães da urbe perfeita, pela pedagogia excelente, que instrui seus filhos para que, no porvir, sejam bons e sadios cidadãos, para então, conquistarem a plenitude a fim de viver no melhor dos mundos possíveis. 
Ainda na mesma seção, observa-se que a formação embebida de magia, como parte da Paidéia Poética, é explanada por meio de um guia preventivo e explicativo sobre uma moléstia que fez vítimas em Paris, em 1832 e 1874, Le Choléra, assustadora doença que é apresentada com um tom de alarme, perigo que pode voltar a qualquer momento, "La rapidité

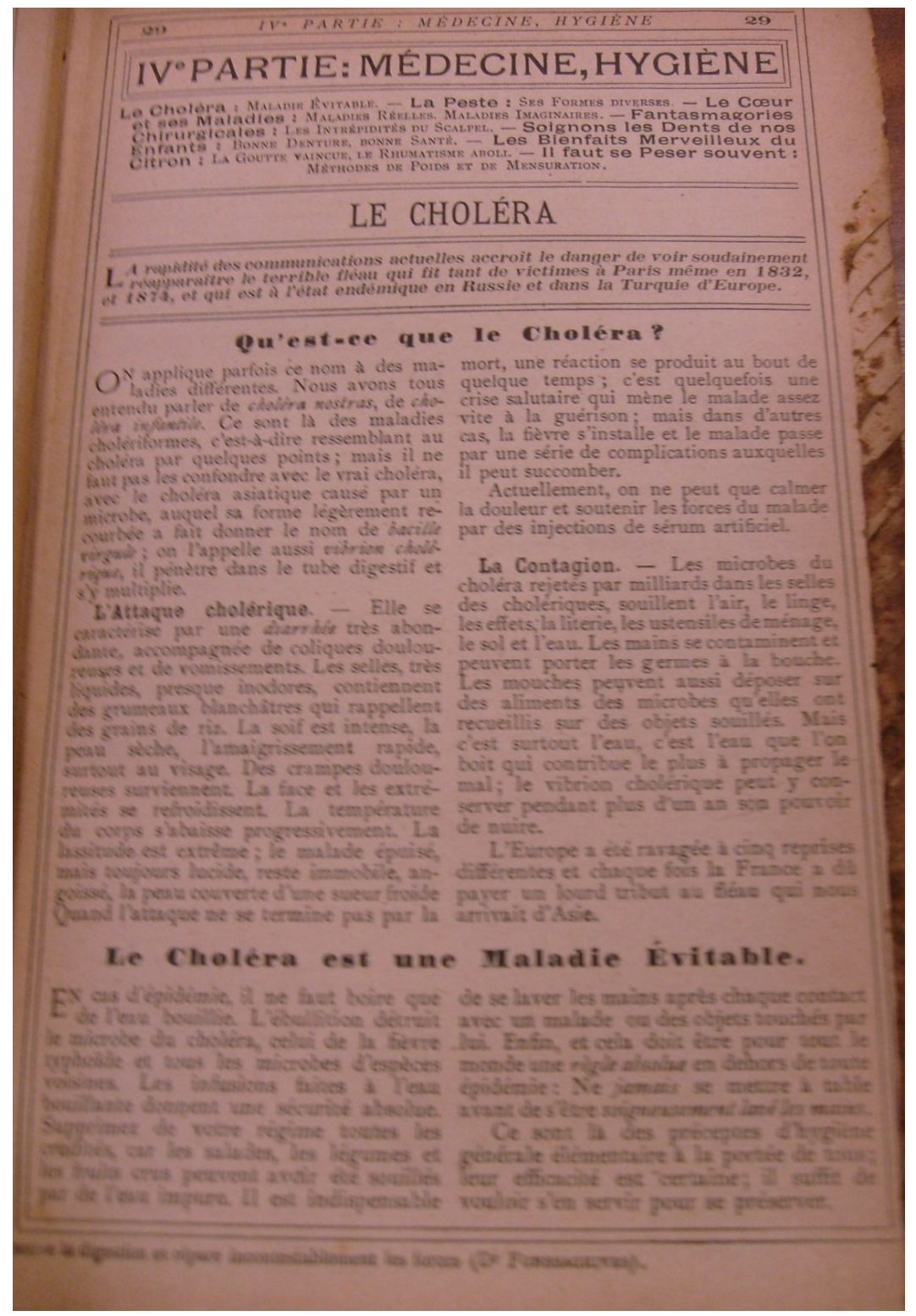

des communications actuelles accrô̂t le danger de voir soudainement réapparaître le terrible fléau...”, mas que pode ser evitada pela preservação da higiene, posto que o contágio se dá pelo contato com o matérial fecal dos doentes, ou seja, é apenas seguir as orientações inscritas na poética de almanaque, que simbolicamente se tem a proteção de tais enfermidades em um microcosmo de cura e onirismo. O texto ainda informa os leitores que os micróbios do cholé- 
ra contaminam o ar, as roupas, a leiteira, os utensílios de limpeza, o solo, a água e as mãos que podem levar os germes à boca, além das moscas que depositam nos alimentos, micróbios que recolheram em objetos contaminados. É na formação de leitores sábios e saudáveis, que a Paidéia Poética opera, fazendo da educação pelo sonhar, o caminho quimérico para a construção da polis utópica, tendo no poder cíclico do tempo, doutrina que remete novamente à civilização grega, a regeneração dos males da cidade moderna. A circularidade do tempo permite que os prognósticos dos almanaques sejam feitos a partir do percurso dos planetas nos pontos do zodíaco, sempre respeitando uma regularidade de intervalos, além do aprisionamento simbólico de seu decurso nos calendários, não apenas os perpétuos, que parecem reter a sua inexorabilidade, dando a impressão de que a longevidade é assegurada. É, pois, baseado no eterno retorno, que se observa a temática da cidade devastada pela epidemia, fazendo do ato de recordar a moléstia, a salvação do presente pelo passado, consequentemente, do porvir. Ora, pelo poder oracular, haja vista o caráter místico-poético dos almanaques, tem-se o retorno do mesmo prenunciado, ou melhor, o mal travestido de uma roupagem de cura simbólica.

Além do alento que se oferta aos leitores por meio do ato de rememorar o mal, purificando-o de seus poderes maléficos, por meio do encantamento poético, tem-se na doutrina cíclica do tempo, a salvação de sua inexorabilidade, haja vista que situações do passado podem ser revividas e retomadas ininterruptamente, livrando o homem do sofrimento diante da temporalidade. É o ato de recordar os eventos passados nos almanaques, que remetem à Paidéia platônica concernente ao aprendizado baseado nas reminiscências, ou seja, ao recuperar a memória de uma existência puramente espiritual, adquirimos as verdades encontradas apenas no mundo das Ideias que, por sua vez, foram esquecidas no momento da reencarnação das almas. Mediante tal aprendizado embebido de onirismo no microcosmo poético de almanaque, considera-se o que Eliade menciona sobre a teoria platônica, que se traduz no apreender por meio do rememorar, tendo a alma na contemplação das Ideias, o alcance do conhecimento puro e perfeito. Tal saber é esquecido no momento em que a alma reencarna, posto que bebe da fonte do Letes e se olvida do conhecimento adquirido por meio da contemplação direta da Ideias. Malgrado tal esquecimento, o saber permanece latente no homem encarnado, podendo ser recuperado por meio do esforço filosófico, ou do alcance do Sublime no melhor dos mundos possíveis de almanaque, tendo nos objetos físicos o suporte 
para que a alma recolha-se para dentro de si, como uma espécie de "voltar atrás" que recobra o conhecimento original de seu estado primeiro ${ }^{31}$.

É, dessa maneira, que a poética de almanaque vale-se do rememorar a fim de permitir aos leitores a volta ao estado perfeito, com sua potência místico-simbólica, calcada no conhecimento das origens do Cosmo, que possibilita, em um microcosmo quimérico, o alcance do Bem e do Belo, traduzidos na edificação da urbe ideal, no Sublime do melhor dos mundos possíveis.

Dadas as devidas instruções, observa-se que o discurso informativo sustenta a sensação de proteção dos leitores, posto que além da moléstia ser prevenida ou erradicada, - desde que sejam tomados os devidos cuidados em relação à higiene, "Le Choléra est une Maladie Évitable”, - a quimera, como ingrediente de constituição da urbe excelente, pode servir de abrigo para os perigos correntes, tendo no microcrosmo feérico a panacéia para todos os males. Ora, a menção de supressão da moléstia ou da rememoração de uma endemia já extinta, bem como do discurso preventivo, permite a lisibilidade da cidade parisiense na chamada Belle Époque, visto que o temor diante do alto índice de mortandade na falsa idade de ouro remete à luta contra a morte que, segundo Winok, assiste a um progresso no fim do século XIX, mas que exige ainda muita atenção no tocante ao aprisionamento de água potável, à construção de esgotos, sobretudo nas pequenas cidades, - o que remete não apenas à República das delícias, mas ao Pays de Cocagne como um todo, - à higiene das habitações e dos estabelecimentos industriais. A despeito do recuo da mortalidade, o pavor ainda perdura, momento em que a sociedade sustenta, como nunca, a paúra em face da fatalidade da morte. Angústia que o autor elucida como sentimento portador da máscara de dor em relação a duas enfermidades de contágio sorrateiro, que não preserva niguém, tuberculose e sífilis, e que atinge qualquer idade, entretanto males que inspiraram médicos, poetas e imprecatórios. Malgrado o pavor estar centrado nas duas enfermidades, outros males inscrevem a fantasmagoria da época, elucidados por meio da estatística das principais causas de morte no período em questão e conforme sua nomenclatura, nos anos de 1906 e 1913, a ver: 71.496 e 70.011 de tuberculose, 47.466 e 44.088 de hemorragia, apoplexia e amolecimento cerebral, 27.306 e 32.834 de câncer, 49.889 e 55.824 de doenças do coração, 66.556 e 60.591 de bronquite e pneumonia, 103.373 e 106.876 de senilidade ${ }^{32}$.

$31 \quad$. Eliade, 1963, p.111.

$32 \quad$. Winok, 2003, p.193. 


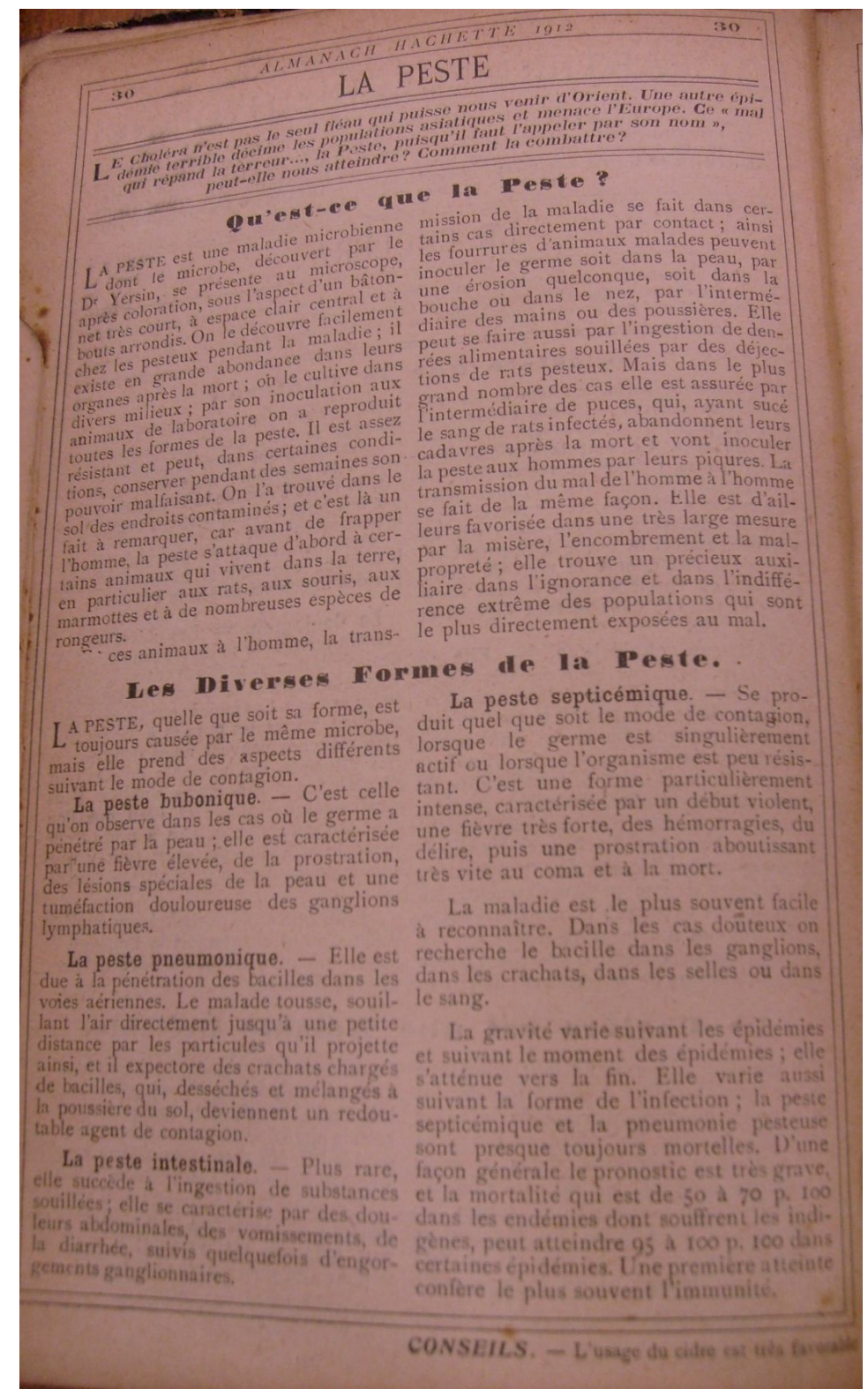

É, pois, nessa realidade moribunda e pavorosa que a poética de almanaque recupera o sonhar que a modernidade tem renunciado, fazendo com que tal microcosmo quimérico, reviva e resgate da ratio corrente, segundo Bosi (1977, p.149), "a grandeza heróica e sagrada dos tempos originários, unindo lenda e poema, mythos e epos", tendo na simbologia de cura para os infortúnios, enfermidades e problemáticas, a salvação pela Fortuna condutora dos livros herméticos. 


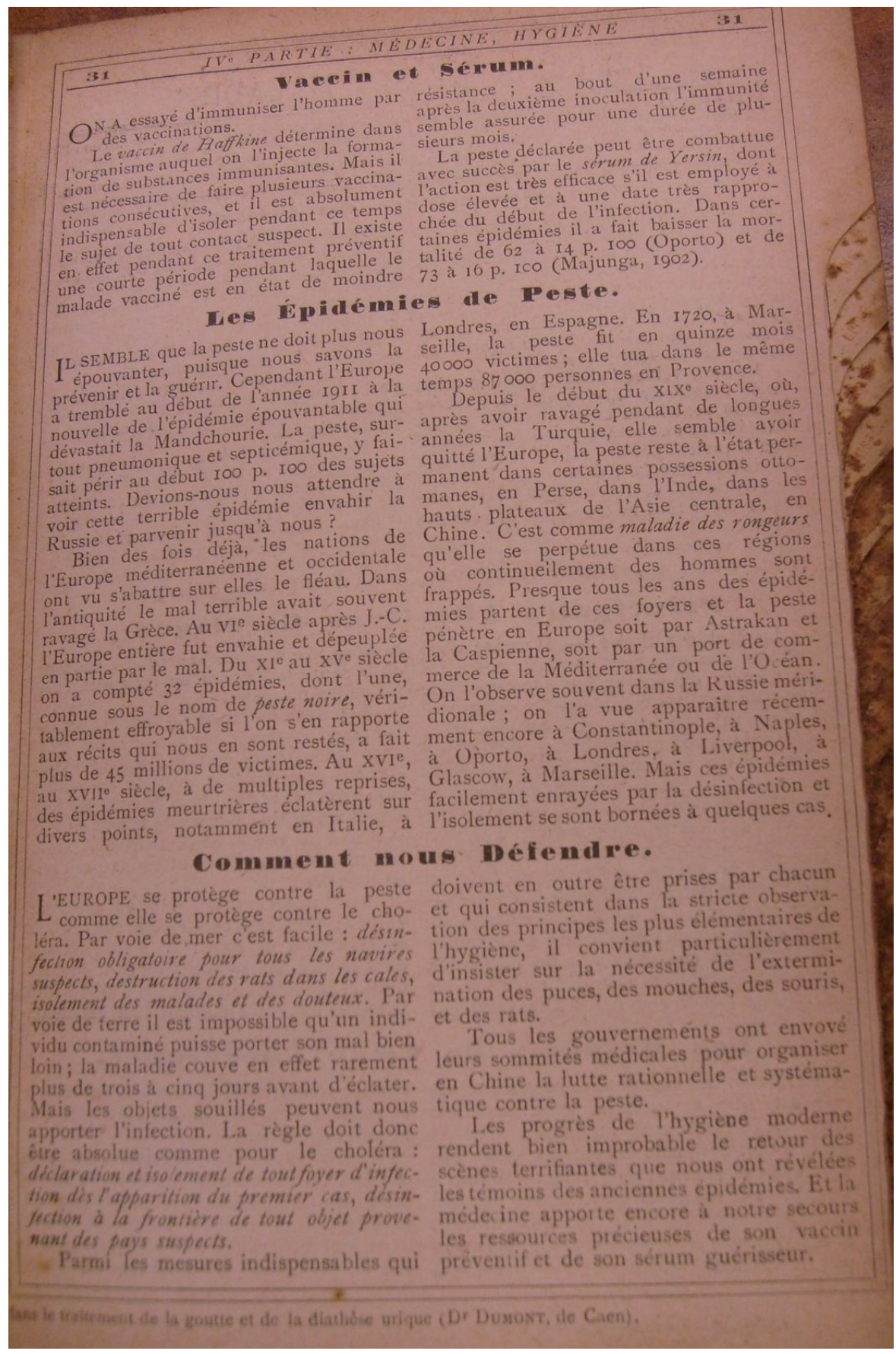

Na cidade utópica, onde se tem proteção para as intempéries cotidianas, constata-se novamente o discurso informativo, que tem função primeira de alertar, para seguidamente, exercer sua eficácia simbólica de abrigo ou cura para os males vigentes ou possíveis de retorno. Ora, a Paidéia Poética persiste na seção, tendo os leitores ainda informações sobre uma epidemia vinda do Oriente, que decima diversas populações asiáticas e que ameaça a 
Europa, trazendo esclarecimentos do tipo, Qu'est-ce que la Peste?, Les diverses formes de la Peste, Vaccin et Sérum, Les Épidemies de Peste, Comment nous Défendre.

Mais uma vez o discurso da higienização faz-se presente, a fim de alertar os leitores sobre os riscos que a falta de asseio pode provocar, visto que a Peste é uma maladie microbienne. Por isso, o texto orienta a estrita observação dos princípios os mais elementares de higiene, além de insistir sobre a necessidade do extermínio das pulgas, das moscas, dos camundongos e dos ratos. É com o discurso da higiene, junto às descobertas médicas e a révolution pastorienne, que a chamada Belle Époque trava uma brava luta contra a morte, tendo na República das delícias sua verdadeira cessação, posto que se na memória da grande cidade, ou mito de Paris, permanecem as reminiscências de uma época de adversidades, moléstias e desventuras, decorrentes de enfermidades como a Cólera e a Peste, dentre outras circundantes e aterrorizantes como as já mencionadas tuberculose e sífilis, a primeira responsável por $7 \%$ das mortes anuais no território francês, a segunda por $13 \%$ a $15 \%$ da contaminação entre a população masculina e os $20 \%$ distribuídos entre os demais da cidade parisiense $^{33}$, também se encontra a salvação - por meio de seu poder mítico, de guia-veta do Destino dos leitores - para os males de outrora, do presente e de sua manifestação fantasmagórica vindoura.

É no controle da Ventura, em consonância com os poderes místicos dos almanaques, que se nota a manifestação, na República das delícias, da Paidéia Poética alicerçada no universo da miticidade. Sendo metáfora de uma epopeia às avessas, a tessitura da polis utópica dá-se na inspiração divina, elucidada por Platão, no processo criativo, concernente à intermediação entre o universo do sagrado e o poeta. É, pois, no mito de Paris, que as musas, representadas pelos santos, astros, prognosticadores, dentre outros, inspiram simbolicamente o aedo da Poética de Almanaque para alcance do Sublime. As musas das artes, tendo por mãe a deusa da memória Mnemosyne, inventora das palavras e da linguagem, indica o auxílio para a escritura onírica da urbe ideal, fazendo das reminiscências ou das situações adversas da modernidade, uma mnemônica terapêutica que permite sonhar com o melhor dos mundos possíveis. Ora, tal microcosmo mítico-poético, remete à consideração platônica sobre a inspiração divina dos poetas, inscrita no Ion, elucidando-os como criadores e anunciadores de belezas pelo favor divino e não graças à arte, apontando o fato de uma bela composição ser feita por tais artífices, apenas no momento em que são possuídos pelo poder da Musa ${ }^{34}$.

\footnotetext{
$33 \quad$.Winock, p. 197 e 199.
}

$34 \quad$. Platon, Ion, 1989, p.101. 
Essa inspiração divina, em consonância com o universo místico dos almanaques, representativa do retorno às origens da Poiésis, direciona novamente à memória do mito de Paris, fazendo do ato de recordar para salvar, pela Paidéia Poética, a oferta de um arsenal de orientações para prevenção e cuidados de seus habitantes, o que é inscrito no contexto histórico de tais livros, podendo ser observado no papel da medicina no século XIX, e prosseguindo de forma semelhante, no início do século XX. Ela produz uma política de controle social, que age por meio do isolamento das doenças, com seus diversos modelos de higiene, visando normatizar e regulamentar as cidades e seus cidadãos. Desse modo, criam-se instituições que visam à contenção das problemáticas da sociedade e de tudo o que tolhe a ordem e a sanidade dos indivíduos. É importante salientar que esse projeto tem realmente êxito, na edificação da urbe ideal componente da Terra sem Males de almanaque, na tessitura poética, que salva seus habitantes dos males da modernidade, pelo alcance do Sublime.

A joie de vivre, prometida como divisa da idade de ouro, não permite a erradicação de inúmeras mazelas sociais, fazendo do ato mnemônico do mito de Paris, de rememorar e alertar seus cidadãos, por meio da Paidéia Poética de almanaque, a verdadeira implementação do projeto da cidade ideal, onde a ordem e as virtudes são alcançadas por meio da salvação da Poiésis. $\mathrm{O}$ ato de reviver tais lembranças adversas, por meio da poética de almanaque, como alternativa para curar os temores correntes oriundos do Caos moderno, remete ao curso da história, à volta à Grécia Antiga, haja vista que de tal período, buscam-se as origens da poesia, a sua miticidade e a edificação platônica da polis ideal. No retorno à Hélade, e posteriormente, na menção à narrativa de Albert Camus, observa-se a memória do mito citadino, como simbologia de descrições reminiscentes, tendo na Mnemosyne a codutora da Paidéia Poética, cujo rememorar é o caminho para o bom encaminhamento da Ventura dos cidadãos da urbe excelente.

Logo, tem-se a epidemia que devastou a população ateniense, em 428 a. C, narrada por Tucídides, na obra "A Guerra de Peloponeso", a Peste - não a mesma causada pelo bacilo Yersinia pestis - como terrível endemia que nem mesmo os oráculos puderam salvar da mortandade avaçaladora. É, pois, no narrar e, a posteriori, no recordar, que o mito da cidade, livra seus habitantes dos temores inscritos no passado, no presente e em seu possível retorno no porvir. Nesse viés, em uma das passagens da obra de Tucídides, mencionada por 
Rezende $^{35}$, observa-se a narrativa como panorama da capital ateniense, retrato de seu tempo, elucidativa de uma perenidade fotográfica:

[...] No começo do verão, os peloponesos e seus aliados invadiram o território da Ática. Firmaram seu campo e dominaram o país. Poucos dias depois, sobreveio aos atenienses uma terrível epidemia, a qual atacou primeiro a cidade de Lemos e outros lugares. Jamais se vira em parte alguma açoite semelhante e vítimas tão numerosas; os médicos nada podiam fazer, pois de princípio desconheciam a natureza da enfermidade e além disso foram os primeiros a ter contato com os doentes e morreram em primeiro lugar. A ciência humana mostrou-se incapaz; em vão se elevavam orações nos templos e se dirigiam preces aos oráculos. Finalmente, tudo foi renunciado ante a força da epidemia. (REZENDE, 2009, p.2)

A representação funesta de Atenas, com suas ruas encarpetadas de vítimas e de terror, remete à temática que desde os primórdios assusta a existência humana, a finitude. Estando caracterizada pela Peste, em um contexto rico em simbologia, é mister elucidar o pavor que o deus Hades exercia nos helênicos, tendo muitas vezes seu nome jamais pronunciado ou modificado por outros vocábulos, com o intuito de não atraí-lo. É, pois, com os temores que cercam a população ateniense que se inscrevem a memória da Hélade, tendo na presença indelével da morte, a certeza da finitude do ser, que nem mesmo os diversos deuses tiveram poder para afugentar.

Ao tomar a cidade platônica como referencial simbólico, considera-se a proposição da imortalidade da alma como resposta acalentadora para a finitude, com todos os seus desdobramentos místico-oníricos da poética de almanaque. Ora, além do retorno às origens da poesia que salva os leitores do mundo sensível adoentado da modernidade, têm-se os santos, os astros, os prognosticadores, os elixires que prolongam a vida, ainda como promessa apaziguadora diante da certeira "indesejada das gentes", segundo o poeta Manuel Bandeira, a imortalidade da alma platônica, cuja habitação primeira é o mundo das Ideias, traduzida por meio do renascimento incessante do ato poético a cada feitura de almanaque. Logo, na transcendência, alcançamos a essência do mundo, onde a alma se liberta do corpo, sua prisão, atingindo a Verdade, pelo processo dialético, ou seja, pelo discurso. É, no retorno da alma ao mundo inteligível, que se inscreve a Paidéia Poética dos almanaques, visto que na confluência poético-filosófica, haja vista a não-compartimentação dos saberes em tais livros herméticos, os leitores alcançam nesse mundo autônomo, aqui lisível como repleto de

35 . O artigo intitulado "As Grandes Hepidemias da História" de Joffre M. de Rezende foi publicado no ano de 2009, no livro A sombra do plátano, pela Editora Unifesp. 
quimera, a salvação para os enganos e as problemáticas do mundo sensível. Dessa maneira, o mundo das Ideias carregado de poeticidade, permite a lisibilidade da urbe concreta, Paris, transformando-a por meio da Paidéia Poética, em abrigo para as moléstias, tendo no microcosmo onírico, a proteção do divino em suas diferentes representações.

Considerando a memória do mito de Paris, com suas reminiscências, tanto do mundo das Ideias, quanto da carga mnemônica que guarda das situações adversas vividas, passa-se para mais uma elucidação das recordações que a urbe guarda de seu passado, a temática recorrente da cidade devastada pelas endemias no curso da literatura. A retomada do tema da cidade, no caso Oran, representando, dessa maneira, sua memória no decurso do tempo, dáse na narrativa de Alber Camus, nomeada A Peste, cujo enredo desenvolve-se no relato assombroso de tal urbe acometida pelo surto. Desse modo, a literatura ou a própria memória da cidade são testemunhas dos terrores que as epidemias causaram ao longo dos séculos, fazendo do narrar, o reaprendrer a sonhar em meio ao cenário sinistro das urbes enfermas, como retratos de uma poeticidade que nasce no momento em que o Nada aparece, a finitude salva pelo poder Sublime da Poiésis. A título de ilustração, é relevante analisar algumas passagens da obra de Camus $^{36}$ que retrata o cenário de mortandade da cidade de Oran:

[...] - Oh! Comme d'habitude. Comme d'habitude! C'est-à-dire que le nouveau sérum envoyé par Paris avait l'air d'être moins efficace que le premier et les statistiques montaient. On n'avait toujours pas la possibilité d'inoculer les sérums préventifs ailleurs que dans les familles déjà atteintes. Il eût fallu des quantités industrielles pour en généraliser l'emploi. La plupart des bubons se refusaient à percer, comme si la saison de leur durcissement était venue, et ils torturaient les malades. Depuis la veille, il y avait dans la ville deux cas d'une nouvelle forme de l'épidemie. La peste devenait pulmonaire. Le jour même, au cors d'une réunion, les médicins harassés, devant un préfet désorienté, avaient demandé et obtenu de nouvelles mesures pour éviter la contagion qui se faisait de bouche à bouche, dans la peste pulmonaire. Comme d'habitude, on ne savait toujours rien;

[...] Et bien, ce qui caractérisait au début nos cérémonies c'était la rapidité! Toutes les formalités avaient été simplifiées et d'une manière générale la pompe funéraire avait été supprimée. Les malades mouraient loin de leur famille et on avait interdit les veillées rituelles, si bien que celui qui était mort dans la soirée passait sa nuit tout seul et celui qui mourait la journée était enterré sans délai. On avisait la famille, bien entendu, mais dans la plupart des

36 . Excertos retirados da obra La Peste de Albert Camus, Paris: Gallimard, 1960, páginas 140, 191, e 131 - 132 referentes à última citação. 
cas, celle-ci ne pouvait pas se déplacer, étant en quarantaine si elle avait vécu auprès du malade. Dans le cas où la famille n'habitait pas avec le défunt, elle se présentait à l'heure indiquée qui était celle du départ pour le cimetière, le corps ayant été lavé et mis en bière; [...] Écoutant, en effet, les cris d'allégresse qui montaient de va ville, Rieux se souvenait que cette allégresse était toujours menacée. Car il savait ce que cette foule en joie ignorait, et qu'on peut lire dans les livres, que le bacille de la peste ne meurt ni ne disparaît jamais, qu'il peut rester pendant des dizaines d'années dans les meubles et le linge, qu'il attend patiemment dans les chambres, les caves, les malles, les mouchoirs et les paperasses, et que, peut-être, le jour viendrait où, pour le malheur et l'enseignement des hommes, la peste réveillerait ses rats et les enverrait mourir dans une cité heureuse.

É, pois, a cidade devastada pela peste, como personificação da própria morte, vista por toda parte, em suas ruas, esquinas e becos - tendo na elucidação bandeiriana, "a companheira de todas as horas", o fantasma que assola, há tempos, o imaginário da humanidade - que Camus a retoma como temática, mantendo sua memória na escritura que apazigua os temores passados, presentes e vindouros. Pela simbologia do não-chorar seus mortos, a urbe se transforma em metáfora de uma sepultura coletiva, na qual os corpos são enterrados na indigência, sem qualquer ritual funerário que amenize a dor da perda. Ora, o pavor que a epidemia provoca nos habitantes das cidades, desde a Hélade, passando por tantas outras, é inscrito na modernidade pela narrativa camusiana, com um discurso elucidativo do panorama da moléstia no século XX, a alta redução de casos, o que é traduzido pela comemoração, com gritos de alegria dos moradores de Oran, decorrente da erradicação da enfermidade ao final da obra.

Como o próprio doutor Bernard Rieux adverte em um silêncio ameaçador, tais brados de celebração podem ser suprimidos pelo retorno do bacilo, que permanece durante anos nos cantos sombrios do esquecimento, mas que pode ressurgir com seus ratos, para tão logo, ser aniquilado em uma cidade feliz. Logo, o discurso de ameaça-consolo, inscrito por meio da advertência sobre a conduta da humanidade, os males gerados por ela, podem acordar os roedores para a morte em um idílio repleto de ventura, ou seja, a verdadeira edificação de uma urbe quimérica, livre das mazelas da modernidade. A oferta de uma cidade feliz ao final da narrativa dá sustentação a mais uma utopia, posto que em tal urbe ideal, seus habitantes estarão realmente livres da assustadora enfermidade, o que vai ao encontro da leitura aqui desenvolvida, posto que na tessitura poética da polis perfeita, Paris, representativa do melhor dos mundos possíveis, os males que circundam seus moradores são extinguidos. 
Outro exemplo que elucida a Paidéia Poética para a excelência, na cidade parisiense, são as recomendações feitas aos leitores a respeito da alcova de um doente e de sua limpeza, La Chambre et La Toilette Du Malade, lisível ainda como extensão da atmosfera temerosa diante do alto índice de casos de morte, bem como de seu tratamento, com doses de poesia, prescrito pela terapêutica de almanaque.

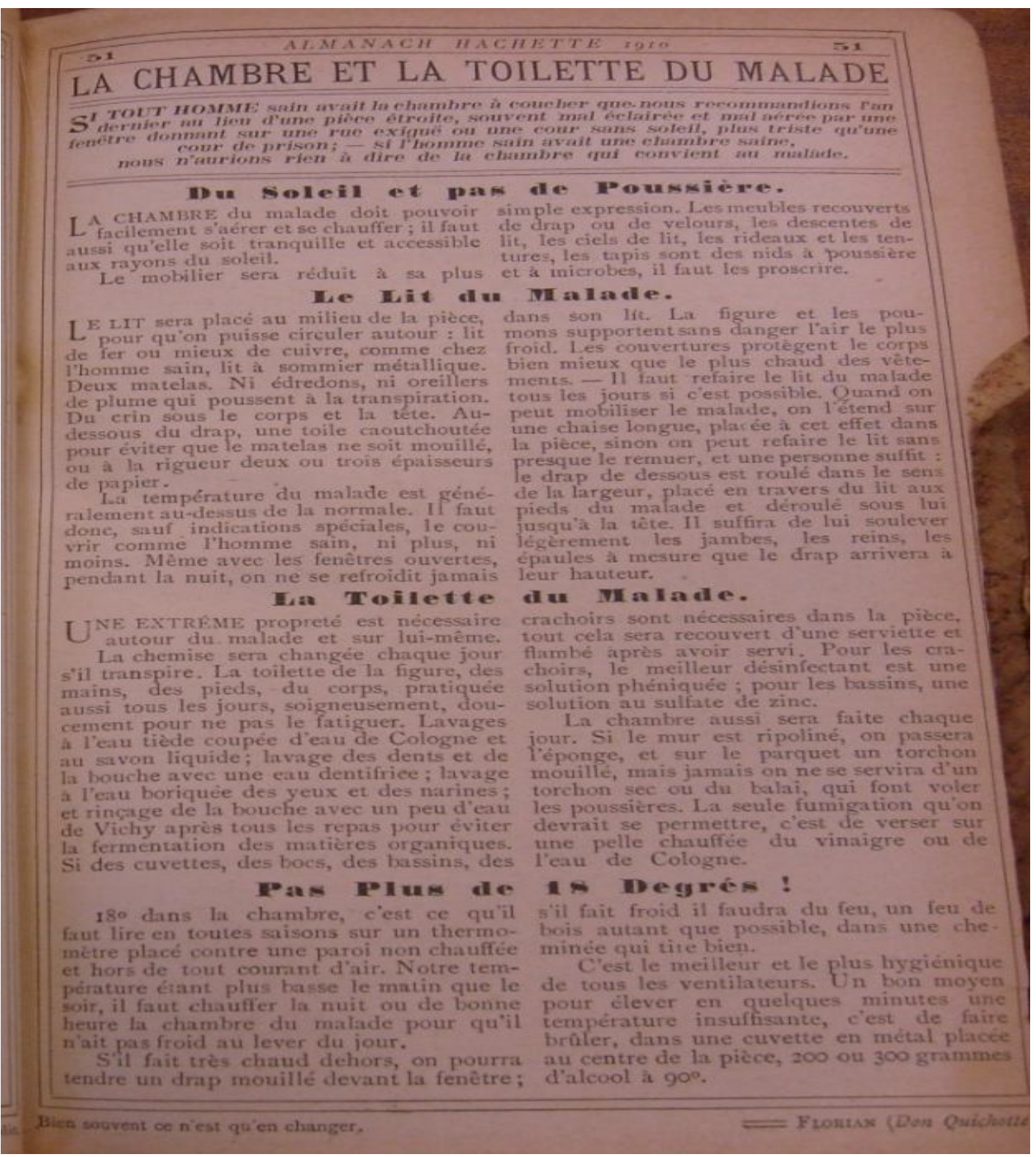

Dessa forma, o discurso de formação de homens sadios e virtuosos é observado nas recomendações familiares de como deve ser o quarto de um homem doente e ainda de que maneira esses cuidados poderiam ter sido evitados caso o enfermo tivesse sido vigilante para com o espaço físico e o asseio de tal acomodação. Isso se dá de maneira informativa, mas com 
um tom de advertência, inscrevendo-se na recomendação incisiva de que se todo homem sensato tivesse mantido o quarto recomendado pelo almanaque do ano anterior, não haveria necessidade de dizer nada sobre tais cuidados nessa edição. Sendo assim, o quarto de um homem prudente, não deve ser organizado em um recinto estreito, mal iluminado e mal arejado por uma janela que dá para uma rua pequena ou uma quadra sem sol, mais triste que um pátio de prisão: SI TOUT HOMME sain avait la chambre à coucher que nous recommendions l'an dernier au lieu d'une pièce étroite, souvent mal éclairée et mal aérée par une fênetre donnant sur une rue exiguë ou une cour sans soleil, plus triste qu’une cour de prison ; - si l'homme sain avait une chambre saine, nous n`aurions rien à dire de la chambre qui convient au malade, lisível como discurso de proteção para com os leitores, mas também como ato denunciatório da realidade habitacional precária em que muitos moradores, de Paris e sobretudo da periferia, estavam sujeitos, que segundo Winock, representava os bairros populares, com suas moradias classificadas em 32000 insalubres sob um total de 80000 imóveis, principalmente ao leste da cidade, em contraste com os belos bairros do oeste ${ }^{37}$.

O caráter educativo do texto prossegue na oferta de um ambiente simbólico protegido das mazelas sociais, das epidemias e dos hábitos não-cultivados, condizente com uma população sadia e de hábitos corretos, levando novamente à Paidéia platônica, que busca no alcance das quatro virtudes, sabedoria, temperança, coragem e justiça, a construção da República ideal, combinada à quimera da urbe dos sonhos de almanaque. Para tal ideal de cidade, considera-se a menção do diálogo platônico referente à fundação excelente da polis harmônica, apresentada como verdadeiramente sábia, posto que é prudente em suas deliberações, o que é elucidado como uma ciência, com a qual se faz um julgamento positivo em detrimento da ignorância ${ }^{38}$, fazendo do diálogo entre a República platônica e a República das delícias, a edificação do sítio excelente de almanaque que possibilita o alcance do Sublime em meio à desordem moderna, como uma espécie de nova Criação a partir massa caótica da modernidade.

É na fundação da cidade prudente ou no mito de Paris, tomados como o próprio retorno às origens, que se tem na modernidade, a busca de uma poética resguardada do Caos do mundo moderno, que cura o enfermo dos enganos e das moléstias por meio do onirismo das mitologias, olvidado pelo tempo que preza pela ratio utilitarista, mas regenerado pelo decurso maravilhoso. Ora, é na alcova inserida no microcosmo quimérico de almanaque, pertencente à

$37 \quad$. Winock, p.367.

38 .República, 428 a, b, pp. 146-147. 
urbe utópica, parte da Terra sem Males que, por sua vez, está em consonância com o Cosmo, que se observa uma espécie de magia íntima para com os leitores adoentados, ou seja, é no aconchego do lar que o ritual simbólico de tratamento e de prevenção das enfermidades é realizado. É, pois, na Paidéia Poética que se tem a posologia para a aplicação do medicamento quimérico, cuja composição é feita por santos de cada dia, dez planetas de cada tema natal, doze signos do zodíaco, áugures dotados de poderes prodigiosos, elixires de longevidade, dentre outros, misturados às orientações de asseio do quarto, das roupas de cama e do moribundo. É por meio dessa terapêutica onírica, que a cura é assegurada, ou seja, na magia combinada às orientações práticas sobre os cuidados exigidos, a ventilação da alcova, seu aquecimento e sua acessibilidade aos raios do sol, além da proteção da mobília, e de tudo o que pode acumular poeira ou micróbios. Na continuação da Paidéia ou do ritual simbólico de "purificação mágica" do espaço ou de cura do enfermo, observa-se que a cama deve ser colocada no centro, a fim de que se possa circular pelo ambiente, ainda corresponder às exigências quanto ao material de confecção e à disposição correta das roupas de cama. Também, é mister acompanhar a temperatura do doente a fim de cobri-lo de maneira adequada, bem como refazer o leito diariamente, com dicas para facilitar tal serviço. A orientação prossegue contemplando uma série de cuidados com o enfermo, dentre os quais, trocar sua camisa diariamente caso transpire, higiene cotidiana do rosto, mãos, pés e corpo, de maneira suave para não cansá-lo e ainda asseio, com solução desinfetante, de recipentes utilizados para micção ou expectoração. O ritual simbólico de cura finaliza com informações sobre a temperatura adequada do ambiente, dezoito graus, atentando para mudanças externas, se muito frio aquecer a chaminé, o contrário, estender uma toalha molhada na janela.

Ao considerar o viés quimérico da urbe utópica, sendo combinado às diferentes representações do sagrado, tem-se a construção, não apenas da polis ideal, mas de uma cosmogonia de almanaque, na qual o Caos da modernidade é transformado em Cosmo, ou melhor, em um microcosmo repleto de deleites, tendo no mito de Paris e na experiência do divino, a edificação de um mundo onde a Beleza é verdadeiramente alcançada. Nessa transcendência poética, na qual seus habitentes podem flanar pelas ruas da sacralidade que salva dos temores externos, o viver não é mais condicionado pela inexorabilidade do decurso, mas pelo Tempo Sagrado do mito, que possibilita a constituição de um novo Tempo, de uma nova realidade, inscrita em uma gênese que permite sonhar. Ora, é no alcance do Absoluto, por meio da Paidéia Poética, que os habitantes da polis ideal têm acesso ao mundo inteligível, ou seja, ao microcosmo de almanaque livre do poder profano da modernidade, tendo no 
Sublime, o caminho para adentrar num mundo a salvo dos males, da finitude, da falsa aparência e repleto de magia.

É, pois, dessa maneira, que a tessitura da cidade ideal é realizada, por meio da Paidéia Poética, cujas lições de bem-viver direcionam seus habitantes a uma vida resguardada das moléstias da humanidade, ao desenvolvimento das virtudes e à possibilidade do sonhar com o melhor dos mundos possíveis.

Como na tessitura da cidade ideal, Paris, tem-se nas informações sobre a salubridade do Rio de Janeiro no Almanaque Brasileiro Garnier para o ano de 1904, a Paidéia Poética que livra seus habitantes das enfermidades e perigos externos, fazendo dos índices de mortandade, a elucidação do microcosmo de almanaque resguardado das estatísticas representativas dos males do mundo moderno.

É dessa maneira que a urbe quimérica é edificada, tendo na simbólica de controle das moléstias, por meio da tabelação dos óbitos e da ênfase na salubridade da cidade carioca, a cura para os desassossegos dos leitores. Nessa oferta de abrandamento e de orientação, tem-se um enunciador que apresenta a cidade por meio de um discurso de enaltecimento de suas condições higiênicas, não obstante o consenso elucidado sobre sua insalubridade, que poderiam ser muito melhores se houvesse maior atenção concernente ao assunto. Prossegue com um tom de atenuação a respeito da concordância sobre a falta de asseio do Rio de Janeiro, tendo no vacábulo exagero a elucidação da leitura errônea que se faz contra a cidade, tomando as considerações do Dr. Pires D’Almeida como explicitação de tal equívoco. Tal demasia é aclarada por meio de uma explanação comparativa com dados de outras cidades, visto que em "1900 o total de óbitos, nessa cidade, nati-mortos excluidos, foi de 13.971 numa população de 751.358 almas, ou - digamos - 18,6 por 1000 habitantes", em confronto com Buenos Aires, que "nesse mesmo anno, nati-mortos excluidos, foi de 16.504, numa população de 821.293 almas; ou - digamos - 20,1 por 1000 habitantes".

Se na Belle Époque francesa observa-se uma brava luta contra a morte, na idade de ouro carioca também se verifica tal batalha à la française, posto que se no metrô parisiense tem-se a proibição de cuspir em seus compartimentos para não propagação de micróbios, do mesmo modo nos bondes do Rio tal ato é vetado, como uma das medidas de Pereira Passos para "civilizar" a população e conter moléstias, o que se segue a sanção do comércio de leite em que as vacas eram levadas de porta a porta, a criação de porcos dentro do perímetro urbano, a exposição da carne na porta dos açougues, a errância de cães vadios, dentre outras. Vê-se ainda os princípios que nortearam as Grandes Obras parisienses serem adotados na urbe 
carioca, como as demolições na Cidade Velha que convergiram com a destruição dos bairros proletários de Haussmann, parte das medidas de afrancesamento do Rio ${ }^{39}$. Se medidas, como alargamento de ruas para melhor ventilação e luminosidade, demolições de bairros que representavam insalubridade, repreensão de comportamentos anti-higiênicos para combate de epidemias, etc, foram adotadas pelas autoridades, vê-se por meio dos dados estatísticos tanto das tabelas, quanto dos já mencionados na cidade parisiense, que a ameaça da morte decorrente das moléstias era uma constante, o que verdadeiramente tem sua supressão nas Re-

públicas das delícias, Paris e Rio de Janeiro, posto que se o antibiótico surge apenas na Primeira Guerra Mundial para combate de tais males, este já não é necessário em tais sítios maravilhosos, visto que a excelência, do microcosmo místico-poético de almanaque, tecida pela Poiésis, é a quintaessência combatente da finitude no Sublime do melhor dos mundos possíveis.

O cotejo concernente aos óbitos das cidades permite uma espécie de simbologia de apaziguamento e cura das enfermidades causadoras de tamanha mortandade, tendo nas 55 cidades elencadas na tabela, no mesmo ano de 1900, a elucidação da importância dos avanços ocorridos no Rio de Janeiro. É no bom posicionamento da tabelação dos óbitos, que o discurso afugenta os temores dos leitores, fazendo do aprisionamento simbólico da morte, a cura para os desassossegos diante das assustadoras epidemias e, por conseguinte, uma sorte de salvação para a finitude personificada pelos números mortíferos. Ao mencionar a posição de $19^{\circ}$ na classificação, o enunciador salienta a relevância de tal dado em relação às outras 36 cidades que tiveram um número maior de mortos, sendo notável o fato de que entre essas estão as principais como Londres, Berlim, Philadelphia, Paris, dentre outras, nas quais a saúde pública é objeto de expressiva preocupação por parte de seus dirigentes. O discurso ainda prossegue por meio de informações quanto à mortalidade infantil de $0 \mathrm{a} 1 \mathrm{ano}$, destacando um lugar significativo na relação, para o Rio de Janeiro, o que se explicita no seguinte excerto: "Deram-se aqui, em 1900, 2241 obitos dentro da cidade, isto é, 17, 4\% sobre a mortalidade

39 . Needell. Belle Époque Tropical. São Paulo: Companhia das Letras, 1993, p.57. 
geral (não compreendidos os nati-mortos), ao passo que em B. Aires houve, dentro d'essa mesma edade, 3,974, isto é, $24 \%$ da mortalidade geral (nati-mortos excluídos)".

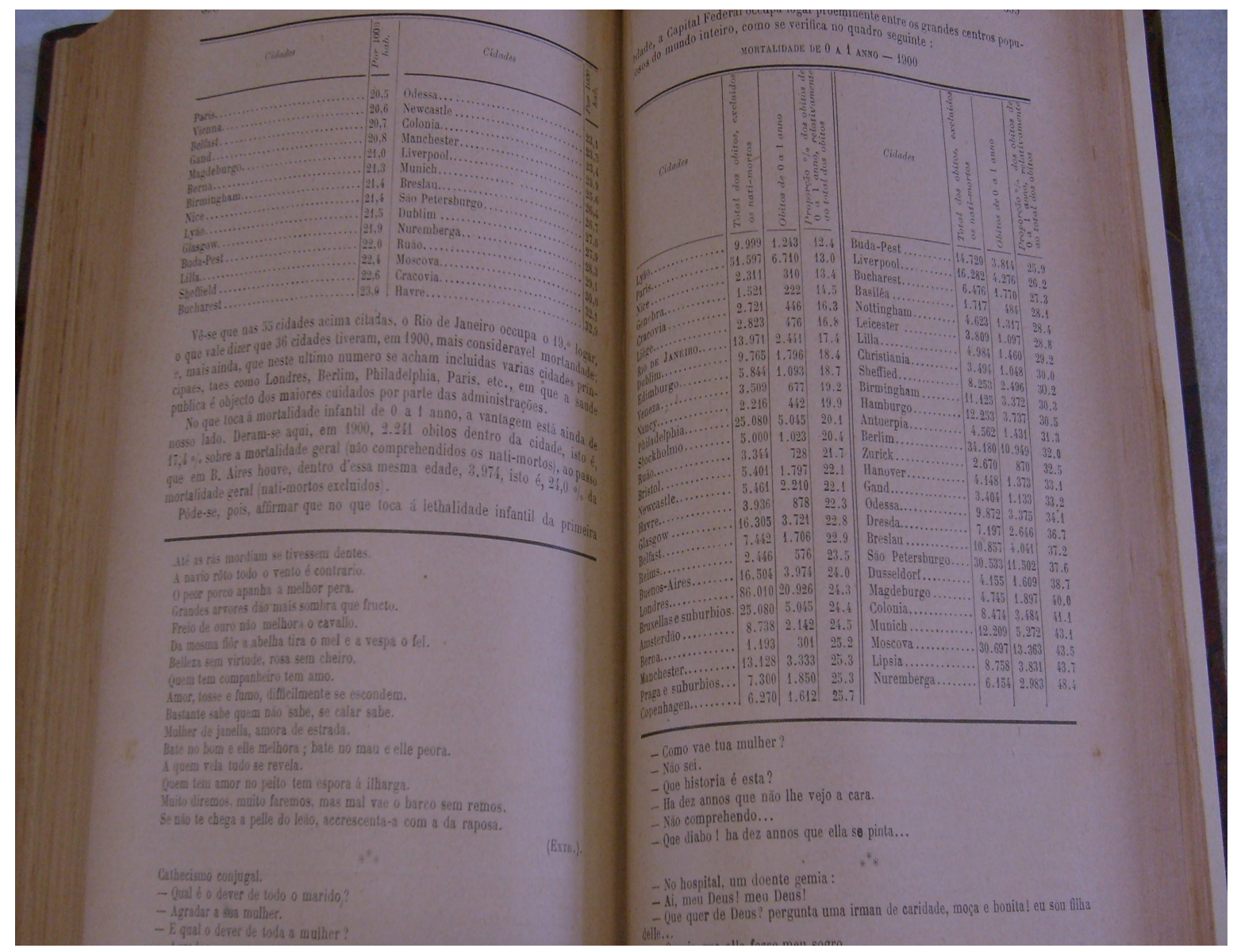

Tendo em vista tais dados, nota-se que o discurso reforça a tese de que o Rio de Janeiro é construído sob a égide da excelência em tal sítio maravilhoso, estando em vantagem sobre cidades consideradas avançadas no que tange à saúde pública, ou seja, seus habitantes são resguardados, no microcosmo quimérico de almanaque, das moléstias que acometem a população e a humanidade. É dessa maneira que adultos e crianças vivem a salvo das problemáticas do mundo moderno, caminhando tranquilamente pelas ruas de ouro em pó do Eldorado conquistado, tendo o bálsamo que cura tanto os males físicos, as doenças e suas consequências, quanto os de ordem espiritual, incluindo a temerosa finitude do ser, que está sob controle nas tabelas que retêm simbolicamente o fenecer do Homem.

Por meio das informações concernentes às estatísticas de mortandade fornecidas pelo doutor, observa-se que há uma espécie de formação dos leitores pelo saber médico, que segue 
o caráter didático da Paidéia Poética de almanaque, o que remete às origens da medicina na Grécia antiga, cuja função estava intrinsicamente ligada à educação e cultura do povo grego. É, pois, o que Jaeger menciona ao elucidar a cultura grega como orientação tanto para a formação do corpo como do espírito, representada pelo liame da ginástica e da música como súmula da cultura grega antiga. Ainda aludi para o fato do surgimento do médico, em uma nova época, em consonância com o professor de ginástica, responsável pela educação física, o que respectivamente, no que tange ao âmbito da orientação espiritual, emerge ao lado do músico e do poeta, como figura relevante, o filósofo. $\mathrm{O}$ caráter pedagógico da literatura médica, segundo o autor, está em consonância com o que os Gregos denominavam como Paidéia, direcionando para o fato dos médicos que expunham, perante o público, suas dificuldades, por meio de "conferências" ou de "discursos", instruir o povo, pela ciência médica, transmitida por uma espécie de atividade ambulante. No ato de educar o povo grego tomando como disciplina didática a medicina, considera-se também o que o autor elucida sobre a epidemia da peste, supracitada, durante a guerra do Peloponeso, acontecimento que possibilitou o surgimento de toda uma literatura médica, consultada de maneira voraz pela população. Tal fato serviu para o historiador Tucídides, leigo no tocante aos temas da Medicina, delinear em sua prodigiosa obra os sintomas da doença, contemplando uma série de hipóteses incongruentes a respeito da causa da epidemia. Essa medicina como Paidéia, citada pelo autor, é relevante na medida em que se analisam as informações concernentes à salubridade do Rio de Janeiro, sendo importante ainda mencionar a teoria da dieta da Antiguidade, tendo na obra Da Dieta, orientações de como o médico devia utilizar sua arte para promover a obra da natureza, força espontânea e inconscientemente teleológica, prevenindo os males circundantes e velando pela sanidade. Esse "manual pedagógico médico" é elucidado por meio da caracterização do médico antigo, que preza mais pelos são do que pelos doentes. A priorização do sadio é nomeada na Medicina de então, como higiene, tendo seus cuidados inscritos sobre a dieta. Ora, os Gregos entendiam por dieta não apenas a elaboração alimentícia do enfermo, mas também toda a cadência de vida do Homem, representada pela orientação dietética em harmonia com os cuidados corporais, tendo o médico, segundo o viés teleológico do organismo humano, uma expressiva missão educativa. Tais obras dietéticas exerciam o papel de instrução dos gregos concernente a uma vida saudável, tendo na observação diária da dieta, o segredo para a saúde do corpo e do espírito ${ }^{40}$.

40 . Para melhor entendimento do exposto, ler capítulo "A Medicina Como Paidéia" do Livro Quarto da obra de Jaeger já mencionada, pp. 1014, 1016, 1040 e 1041. 
É com o mesmo caráter educativo que as informações do doutor Almeida são utilizadas no almanaque, fazendo dos dados médicos uma espécie de Paidéia Poética que salva o corpo e o espírito dos males vigentes, associada à cultura de almanaque que educa os habitantes da urbe ideal para a excelência, tendo na Primeira Grécia, a medicina e a cultura em consonância, o modelo para tratar tanto o corpo quanto a alma, o que é característico do gênero aqui analisado, velar pelo Homem em sua integralidade. Assim como os médicos expunham seu saber em "discursos" e "coferências", tem-se na figura do doutor aquele que assume um papel de educador por meio das páginas herméticas do almanaque, também um agente formador da literatura médica popular, acessível a todos, incrita por meio das temáticas abordadas concernentes à sanidade dos habitantes da cidade quimérica, também ambulante no sentido de atualizar o mascatear que adentra nos lares pelo comércio de almanaquias para deleite. Ora, a literatura médica, que surge a partir da epidemia de Peste durante a guerra do Peloponeso, é rememorada na já citada obra de Camus, para elucidação da endemia na cidade de Paris, aqui lisível como o retomar das reminiscências de tal moléstia e de outras que assolaram a população no ano de 1900, haja vista que tais informações são apresentadas no Almanaque para o Ano de 1904. O ato de recordar por meio da Paidéia Poética, novamente direciona às origens gregas, que faz da ciência médica como disciplina didática, a cura para os desassossegos da alma e dos males do corpo, cuja volta à Antiguidade possibilita a recuperação simbólica da idade de ouro hesiódica e a vivência da Eudemonía, vida ditosa, na urbe moderna.

O caráter pedagógico das estatísticas de mortandade de adultos e crianças ainda remete à teoria da dieta da Antiguidade, tendo nas informações um discurso implícito de zelar pela higiene ou saúde do corpo e, por conseguinte, da alma, com prescrições simbólicas de como se deve manter a sanidade e afastar os perigos que a espreitam, o que direciona às dicas de atividades gímnicas e de outra natureza dos almanaques, e aos cuidados com o espírito por meio dos guardiões da boaventura, os astros, os santos, os prognosticadores, etc. Logo, as obras dietéticas que zelavam pela constituição global do Homem, que segundo Jaeger ${ }^{41}$, seguem o viés da escola hipocrática, fazia do médico um observador do meio ambiente, do lugar, do clima e das transformações no Cosmo, ou melhor, da natureza como um todo, para tratar de maneira eficaz os enfermos. É a mesma preocupação que se observa na poética de almanaque, posto que além de abrir os olhos para a verdadeira Beleza do mundo, em hamonia com o Universo, também preza pela boa alimentação, associada aos exercícios físicos e aos

41 . Ibidem, p. 1044. 
cuidados com o espírito, prescrevendo uma espécie de dieta para sonhar, que salva os leitores das problemáticas e da falsa aparência modernas.

E, pois, na pedagogia da sanidade, que o discurso finaliza com uma tabela descritiva de doenças que acometeram a população no período de 1870 até 1901. Ao rememorar tais moléstias pela tabelação das mortes ocorridas no interregno assinalado, tem-se uma sorte de prescrição apaziguadora para a ameaça circundade concernente a tais epidemias, como a cura e o resguardo simbólicos pelo ritual de aprisionamento dos agentes causadores em um quadro cujo emplastro envoltório protege os leitores das pavorosas enfermidades. É dessa maneira que os leitores e habitantes da urbe ideal estão a salvo dos males que afligem o seu meio, posto que o recordar um passado deveras recente elucida a presença ameaçadora de tais doenças. Ora, a Paidéia Poética prescrita por um de seus auxiliares, o doutor Almeida, como um guia médico, - ou manual de saúde já destacado na literatura popular, - preventivo e informativo, assegura proteção aos leitores do almanaque, cuja dieta de deleites os resguarda das doenças elencadas na tabela, Tuberculose, Febre Amarela e Varíola na cidade do melhor dos mundos possíveis. 


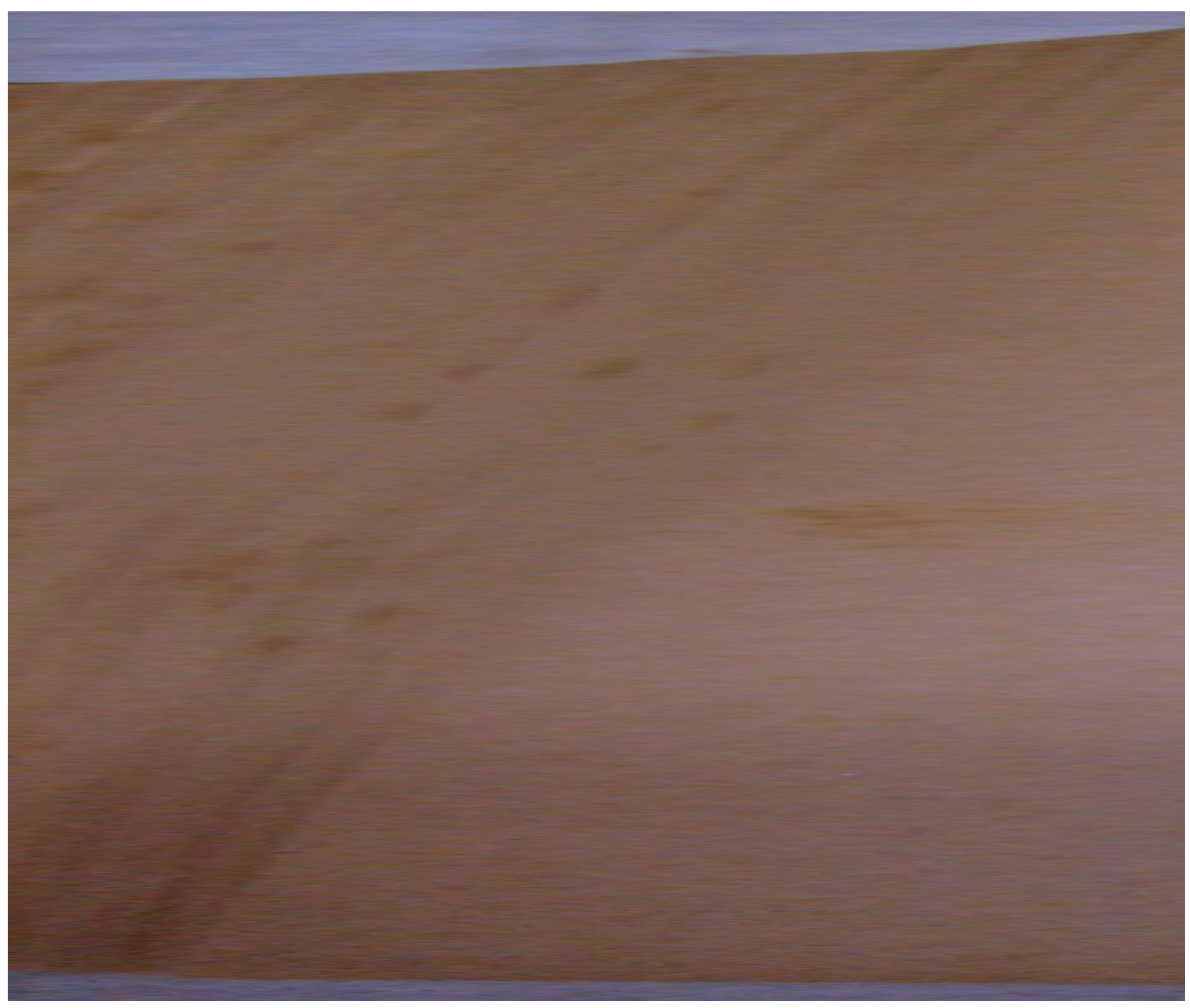

O repassar tais óbitos e a ênfase no progresso concernente à salubridade do Rio de Janeiro do início do discurso sustentam a tessitura da cidade ideal, visto que o tempo adotado é o do pretérito, salientando a tese de que tais enfermidades ficaram em um passado de retrocesso, cujo presente é edificado sob a égide da ventura, ou melhor, na urbe da excelência de almanaque. Ora, a análise da conquista do in illo tempore, uma cidade sem males, a exemplo da Criação a cada feitura de almanaque, remete à obra que dialoga com a tese desenvolvida, A República de Platão, à polis ideal por ele arquitetada, à educação desde a mais tenra idade que visa o Homem são em sua integralidade. Logo, ao tomar a medicina como Paidéia, é importante elucidar uma passagem de Platão que explicita os cuidados com a dieta dos guardiães, evocando uma proposição de Homero com a qual se deve apreender, a prudência nos banquetes dos heróis durante as campanhas, não lhes servindo peixes, ainda 
que à beira-mar, no Helesponto, tampouco carnes cozidas, apenas assadas. Tendo ainda cautela para com os temperos e tudo aquilo que seja prejudicial para manutenção do corpo em boa forma. Prossegue no Livro III, no diálogo entre Sócrates e Gláucon, com uma espécie de orientação quanto à cadência de vida dos habitantes da polis harmônica, comparando tal alimentação e regime de vida, à melodia e ao canto com todas as harmonias e os ritmos, atentando para o fato de que a intemperança gera a doença, ao passo que na música a simplicidade promove temperança nas almas, e na ginástica, a sanidade para os corpos ${ }^{42}$. É, pois, por meio do liame entre a ginástica e a música que Platão apresenta a arte médica, cuja semelhança às obras dietéticas supracitadas, busca o desenvolvimento global do Homem.

A dieta platônica baseada nos cuidados corporais e espirituais, combinada às receitas prescritas de poeticidade, elucida sobremaneira o cerne da cultura de almanaque que, pela Paidéia Poética, visa à formação de leitores ou habitantes sãos e virtuosos, educando-os para adentrar no mundo quimérico em que o sonhar é o ingrediente principal da dieta que restabelece a alma e o corpo para o Sublime.

É ainda por meio da Paidéia Poética que se observa a salvação das problemáticas do mundo profano, tendo nas orientações baseadas no saber médico popular ou rememorando o Médecin des pauvres francês, médico dos pobres que curava dores de dente, manchas e reumatismos com orações ${ }^{43}$, e o benzedeiro, curandeiro, raizeiro no Brasil, a cura simbólica para a moléstia, tuberculose, que acomete a população do Rio de Janeiro, ainda no Almanaque Brasileiro Garnier para o ano de 1904.

42 . República, 404 c, p. 114. . Andries, 1994, p.213. 


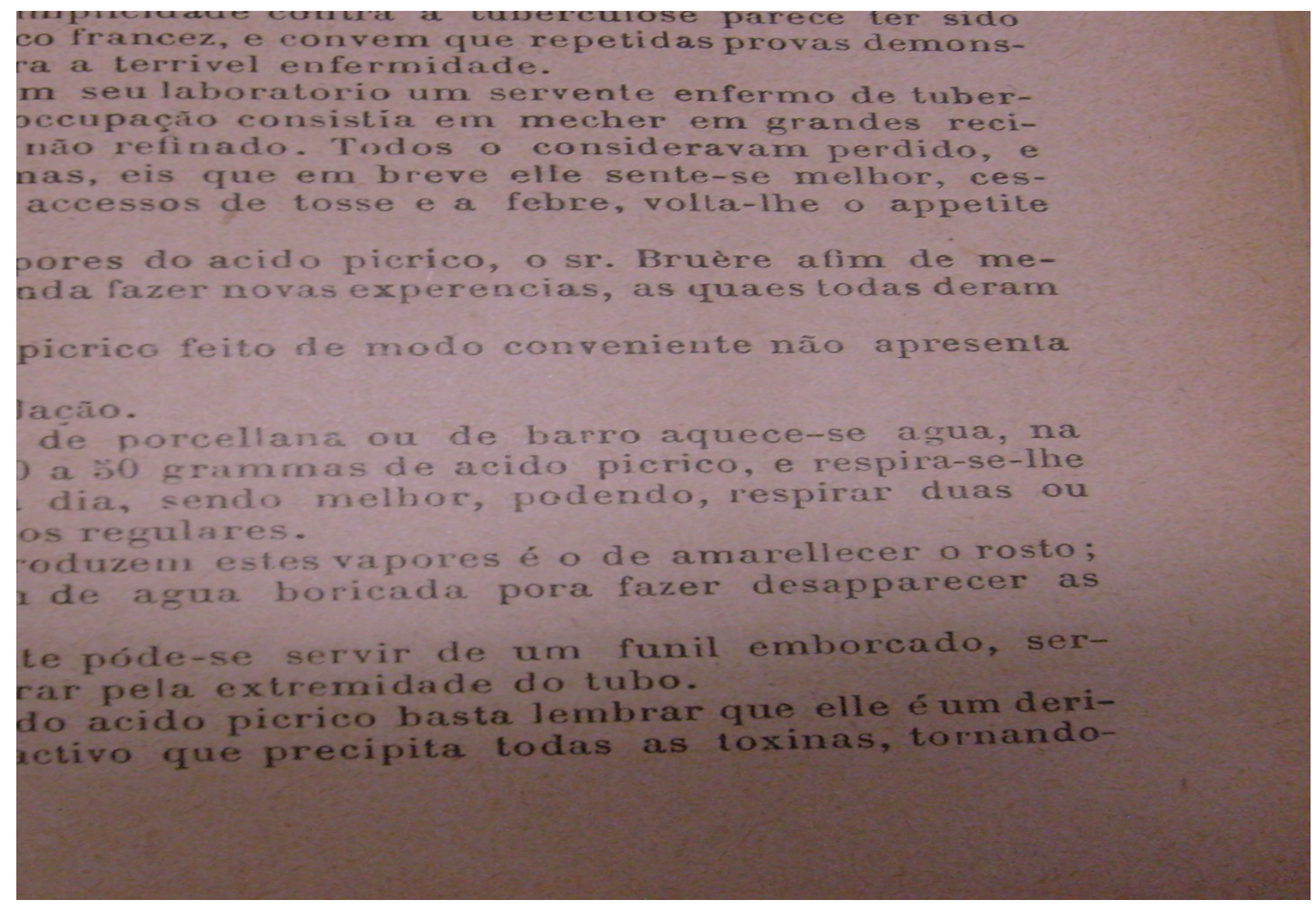

É no discurso pedagógico mesclado ao narrativo, que se tem uma simbólica de proteção "Contra a Tuberculose", título que, de antemão, elucida o combate à sinistra enfermidade. Como a cidade de Paris, cenário de um passado de mortandade causado pela Peste e pela Cólera, tem-se novamente, no Rio de Janeiro, a menção à Tuberculose que assola a população. É a partir da mimesis da realidade enferma moderna que se dá a salvação perante tal mal, ou seja, é na urbe ideal, por meio da formação na excelência, que seus habitantes vivem a salvo dos perigos que espreitam e ameaçam sua Eudemonía. Logo, como no Mito de Paris, verifica-se o ideal da representatividade, o modelo dos deuses seguido no in illo tempore, que também permite a cura para as problemáticas do Tempo Profano ou do Tempo Moderno na cidade do Rio de Janeiro, cujo resgate da idade de ouro, descrita por Hesíodo, livra os leitores das mazelas da modernidade.

Como bálsamo para tal realidade caótica, tem-se no discurso oriundo de uma gazeta italiana, o remédio, descoberto por um químico francês, cuja natureza é de grande simplicidade, eficaz contra a assombrosa enfermidade e legitimado por seus diversos testes. $\mathrm{O}$ enunciador adota um tom narrativo, ao elucidar que o Sr. Bruère tinha em seu laboratório um 
assistente tísico já em grau avançado, cuja função era a de mexer o ácido pícrico quente e não refinado em grandes recipientes. Continua relatando o consenso de todos diante do quadro terminal do enfermo, a morte, que logo é descartada por meio de uma adversativa exclamativa que caracteriza o espanto concernente à cura inesperada, "mas eis que em breve elle sente-se melhor", seguida da interrupção dos sintomas, como a expectoração sanguínea, os acessos de tosse e a febre, recobrando o apetite e o estado de sanidade. Devido ao fato de atribuir tal cura aos vapores do ácido pícrico, Bruère promove uma série de testes para certificar se realmente o restabelecimento da saúde do auxiliar advém do produto, o que é evidenciado com êxito. Mediante o resultado positivo, o discurso adota um teor didático, indo ao encontro da Paidéia Poética aqui analisada, com orientações de ordem posológica para utilização do ácido pícrico, a fim de não apresentar perigo para a saúde.

Dessa maneira, inicia-se o processo informativo, uma espécie de dieta a ser seguida, que se inscreve no modo de utilização do ácido para fins terapêuticos, por meio de uma simples inalação. É na Paidéia curativa do enunciador, que se têm todas as coordenadas para o bom uso do remédio, iniciando uma espécie de ritual de cura a ser seguida pelos enfermos leitores, como o emprego de uma chaleira, panela de barro ou de porcelana para aquecimento da água, que recebe para cada litro 40 a 50 gramas de ácido pícrico, da qual se respira, diariamente, o vapor, durante uma hora, ou visando maior eficácia, de duas a três vezes com intervalos regulares. Tal rito simbólico de cura, em tal microcosmo místico-poético, apresenta um único incoveniente, o amarelamento do rosto oriundo dos vapores, que pode ser solucionado com uma simples lavagem com água boricada para desaparecimento das manchas. Tal importuno ainda pode ser evitado por meio do uso de um funil emborcado, pelo qual se respira pela extremidade do tubo. Para compreensão da ação do ácido no organismo, o discurso finaliza com informações concernentes à origem do ácido pícrico, derivado do ácido fênico e reativo que age nas toxinas, tornando-as inócuas.

É, pois, na realização de todas as etapas do rito simbólico, que se alcança a cura da aterrorizante moléstia que assola a população do Rio de Janeiro, uma espécie de retorno ao in illo tempore pela simples inalação do vapor, ou melhor, de um fôlego quimérico que possibilita a volta à gênese sem males, tendo na proposição de Eliade ${ }^{44}$, que todas as atividades humanas são recorrentes de protótipos míticos, bem como na de Platão ${ }^{45}$, quanto à boa educação dos mestres para com os jovens guardiões a fim de que sejam piedosos e

44 . É relevante ler considerações de Eliade Mircea, sobre as atividades humanas representativas dos deuses, inseridas em Arquétipos de atividades profanas do capítulo Arquétipos e Repetição, p. 36. 45. República, 383 c, p. 84. 
semelhantes aos deuses, na medida do possível para um homem, a elucidação da volta ao Tempo Sagrado nos almanaques, repleto de deuses e de heróis no cotidiano moderno de almanaquias, que salvam os leitores das intempéries da modernidade. É no ato de inalar a cura dos males, que se volta ao sobro Divino da Criação, tendo na Poiésis de almanaque, a responsável pelo resgate do Belo para alcance do Sublime, inscrito na cidade da excelência, do melhor dos mundos possíveis.

Considerando a Paidéia Poética que orienta os leitores com lições de boaventura, tem-se no poetizar o infortúnio, ou melhor, a estetização da cidade do Rio de Janeiro acometida por moléstias, em urbe ideal, onde se dá a abertura para o Divino, o viés adotado pelo flâneurpoeta para a realização da nova Criação. É na recuperação da idade de ouro hesiódica, na volta à Antiguidade, na Paidéia Poética que salva o mundo da falsa ordenação, que se considera o brincar, o poetizar a desdita, por meio de um poeta que tanto exerceu a função de mestre para a salvação do mundo das aparências, Manuel Bendeira ${ }^{46}$, que fez da tísica a campainha responsável pelo seu encontro com o ato criador e pelos tantos alumbramentos de seus leitores. Ora, é no poema intitulado "Pneumotórax" que se observa o fazer poético a partir do mal que acometera o eu-lírico, a tuberculose responsável pela "A vida interia que podia ter sido e que não foi.", no entanto, a mesma que permite o poetizar a desventura como remédio curativo para o corpo e para o espírito, o alumbramento jocoso que salva o sujeito poético do atestado de morte prescrito pelo médico, “- Então doutor, não é possível tentar o pneumotórax?”, “- Não. A única coisa a fazer é tocar um tango argentino.”, o que remete ao brincar, ao dançar pelo ritmo da poeticidade como libertação dos temores diante da finitude. Logo, o procedimento médico, pneumotórax, que não pode salvar o eu-lírico, da "Febre, hemoptise, dispnéia e suores noturnos", da "Tosse, tosse, tosse", que se viu eficaz pelo ácido pícrico do Sr. Bruère, é trocado pelo fazer poético, como sopro que recupera os pulmões comprometidos pela tísica, como bálsamo ou transformação do mal, a morte, em boa "companheira de todas as horas" no Hades já transformado em sítio de delícias.

O fazer poético como doutrina que salva os leitores dos males da vida, direciona ainda à construção, por meio desse mesmo ato criador bandeiriano, à Pasárgada de deleites, aqui lisível como a volta às origens da Poiésis, com seus poetas que poetizam o Tempo Sagrado dos arquétipos míticos, ou melhor, da idade de ouro hesiódica, inscrita no Sublime do microcosmo de almanaque. É, pois, na conquista do in illo tempore, traduzido pelos mitos

46 . Versos retirados da obra Bandeira a Vida Inteira, Patrocínio do Instituto Nacional do Livro e IBM, Rio de Janeiro: Edições Alumbramento/Livroarte Editora, 1986, pp. 61 e 90. 
do Eldorado e do Pays de Cocagne, que se observa a cura para todas as epidemias que acometem as cidades do Rio de Janeiro e de Paris, como os "alcalóides à vontade" ou as almanaquias deleitáveis, que afastam o Homem das dores e dos males da modernidade.

A construção das urbes dos sonhos, Paris e Rio de Janeiro, pelo flâneur-poeta, o leitor das cidades e prognosticador de venturas, dá-se por meio da lisibilidade nos livros sagrados, almanaques, das polis excelentes, tornando-as lisíveis, ou seja, o véu é tirado, o escondido é revelado pela leitura dos inúmeros signos, fazendo da Paidéia Poética, tecedora do Sublime, a concretização dos muitos ideais sonhados na Belle Époque carioca e parisiense. A quimera é o produto utilizado para tornar as cidades lisíveis, em um microcosmo, o almanaque, que possibilita a leitura das imagens de Paris e do Rio de Janeiro em sua totalidade, fazendo do infindável engendro do melhor dos mundos possíveis, a salvação para as mazelas humanas, como uma espécie de rêverie que produz uma embriaguez resgatadora do sonhar em meio à ratio utilitarista moderna. Logo, o almanaque é a própria cidade semiotizada, um caleidoscópio poético de imagens que permite a lisibilidade do mundo moderno - que tem a salvação do Caos da modernidade na volta às origens da Poiésis - possibilitando por meio das lições de bem-viver do flâneur-poeta, a realização das veleidades dos leitores e a construção dos sítios idílicos como atualização da verdadeira idade de ouro no melhor dos mundos possíveis.

É importante salientar que tal oferta de Ventura, as urbes ideais, é garantida pelo flâneur-poeta, leitor e aedo das cidades, uma espécie de áugure que tira seus presságios não do canto e do vôo das aves como os sacerdotes de outrora, mas do poder simbólico de seus livros sagrados, sendo responsável pela mística do controle do tempo e da vida ou da nova Criação, que salva os leitores do Tempo Profano, ou melhor, dos males da modernidade, a cada edição de almanaque. Nesse universo onírico, o flâneur-poeta, uma espécie de Orfeu que permite sonhar, não é expulso da República das delícias, mas o criador da educação para a excelência, tendo na formação de cidadãos virtuosos e na instituição das polis harmônicas, a conquista do Sublime na Terra sem infortúnios de nenhuma ordem. 


\section{Ascese à beleza dos deuses: alcance da plenitude}

A Paidéia Poética responsável pela construção das urbes ideais é a mesma que orienta os leitores para a busca incessante de um padrão corporal, visando à constituição do corpo e da alma condizentes com a excelência das cidades, cuja inexorabilidade do tempo que desgasta a beleza que se quer dos deuses e as imperfeições de ordem física e moral são suprimidas no microcosmo perfeito criado, como resgate do próprio Belo em meio à fealdade simbolizada pelo Caos moderno, para vivência do Sublime, no melhor dos mundos possíveis de almanaque.

Desse modo, os leitores dos almanaques obtêm uma série de orientações para a manutenção ou construção do corpo ideal, ora retardando os efeitos do tempo, ora trabalhando para a manutenção ou seu aprimoramento. Isso remete ao cerne do trabalho aqui desenvolvido, posto que tais dicas estéticas simbolizam as lições para a formação de corpos saudáveis e, por conseguinte, espíritos virtuosos, díade que se traduz na Arete ensinada e representativa das polis ideais, nas quais os leitores têm salvação tanto para os efeitos do tempo, quanto para os males da alma oriundos da modernidade.

Essa busca insana pelo corpo perfeito direciona para o mito da eterna juventude, que desde a Grécia antiga faz-se presente, seja na face de eterna mocidade dos deuses, seja no ideal estético buscado pelos antigos gregos. A Beleza, temática cara aos filósofos e artistas da época, certifica a relevância que o tema do Belo suscita nesse período e que será reiterado pelos séculos vindouros:

O tema da Beleza é elaborado ulteriormente por Sócrates e Platão. O primeiro, segundo testemunho do Memorabilia de Xenofonte (cuja autenticidade suscita hoje algumas dúvidas, dado o facciosismo do autor), parece legitimar a práxis artística no plano conceitual, distinguindo pelo menos três diversas categorias estéticas: Beleza ideal, que representa a natureza através de uma montagem das partes; a Beleza espiritual, que exprime a alma através do olhar (como acontece nas esculturas de Praxíteles, cujos olhos o escultor pintava para torná-los mais verdadeiros); e a Beleza útil ou funcional. Mais complexa é a posição de Platão, da qual nascerão as duas concepções mais importantes da Beleza que foram elaboradas no decorrer dos séculos: a Beleza como harmonia e proporção das partes (derivada de Pitágoras) e a Beleza como esplendor, exposta no Fedro, que influenciará o pensamento neoplatônico. (ECO, 1932, p. 48)

Logo, o ideal estético na Grécia antiga legitima que no decorrer da história o homem sempre ansiou pela obsessão da busca ou manutenção de um corpo ideal, sendo a temática do Belo uma constante que representa ora a alma, ora o idealismo da perfeição ou da sua utilidade. A Beleza que nasce a partir das concepções de Platão, mostra um corpo regulado pela mesma lei que rege as esferas planetárias e sob uma noção bastante rígida de proporção que o harmoniza como um todo. Essa justa proporção que dava beleza ao corpo é traduzida 
dois séculos mais tarde por meio do Cânone de Policleto citado em Eco (1932, p.74) "Todas as partes de um corpo devem adaptar-se reciprocamente, segundo relações proporcionais no sentido geométrico: A está para B, assim como B está para C.”, o que evidencia que a procura por um corpo perfeito tem raízes bastante antigas.

Essa busca insana permanece na cultura medieval com a teoria que nasce ainda das concepções de Platão, a do homo quadratus, na qual o número quatro é a representação do ideário moral e físico, além do homem pentagonal que tem o número cinco como representativo da perfeição mística e estética:

E quatro será igualmente o número da perfeição moral, de modo que o homem moralmente aguerrido será chamado de tetrágono. Contudo, junto ao homem quadrado estará também o homem pentagonal, pois também o cinco é um número cheio de arcanas correspondências e a pêntade é uma entidade que simboliza a perfeição mística e a perfeição estética. (ECO, 1932, p.77)

Tanto o homem tetrágono, quanto o homem pentagonal, direciona para a inquietante temática da Belo que sempre suscitou buscas infindáveis, pois o corpo ideal era decorrente de uma série de correspondências numéricas que, por sua vez, representavam o universo e o idealismo estético. Essa busca pela perfeição perdura nos artistas renascentistas, não mais com a mesma rigidez dos módulos matemáticos medievais, mas sim a partir da teoria do Cânone de Policleto supracitada.

Destarte, nota-se que a busca pelo padrão ideal de corpo é recorrente na história, ora apresentando a rigidez matemática, ora a mística ou até mesmo a divina, sendo traduzida no século XIX na Europa e nos primeiros decênios do século XX no Brasil, por meio da eugenia. A promessa de um corpo perfeito e livre da carga hereditária dos antepassados, bem como das contaminações com o meio, será a preocupação de médicos eugenistas da época influenciados pelos ideais sanitaristas.

Mediante a súmula concernente ao tema da Beleza recorrente no decurso da história, observa-se no Almanach Hachette para o ano de 1910, sítio de engendramento anual da cidade excelente componente do melhor dos mundos possíveis, o velar pela nobreza de seus cidadãos. Ao zelar pelo corpo visa-se o desenvolvimento do espírito, a recuperação ou identificação para resocialização de indivíduos cuja Arete não foi ainda cultivada, lisível no texto La Main des Assassins, a mão e a escrita características dos assassinos, que ministra o esclarecimento necessário a sua recuperação para habitarem na polis ideal, o que permite o resgate da nobreza perdida ou não formada desde a mais tenra idade, para atingir a díade Bem/Belo constitutiva dos habitantes da urbe perfeita e delatora de sua ausência geradora dos males característicos da modernidade. 
Por meio da Paidéia Poética que orienta seus leitores para o desenvolvimento das virtudes, tais imagens e informações revelam os tipos danosos que contribuem para que a República das delícias não seja edificada, tendo na apresentação da escrita de tipos bons e maus da sociedade, não propriamente a do assassino, indicadores de cidadãos nocivos para a idealização da urbe perfeita. Ora, o discurso apresenta os tipos de escrita que revelam boa e má índole, podendo ser modificados pela educação, Paidéia Poética de almanaque, pelo ambiente, pelas circunstâncias da vida e pelo bom senso diante das situações adversas. Logo, a diferenciação, que assume um tom didático, entre um meurtrier e um assassin, é elucidada como o primeiro levado pelas intempéries da vida, ao passo que o segundo tem no traço a impulsividade, a violência e a doença. Diante disso, o grafólogo não acusa, apenas adverte $L e$ Graphologue avertit, mais n'accuse pas, por meio de um discurso doutrinário, cuja ênfase no livre arbítrio do leitor, alerta-o e o lembra de que o ser fraco é um joguete dos acontecimentos/destino: C'est pourquoi nous commençons toute étude par la détermination exacte de la force volontaire de notre sujet, l'être faible est fatalemant le jouet des événements.

O discurso pedagógico para formação de cidadãos sãos, pela Paidéia Poética de almanaque, exclui, para tratamento com doses de poeticidade, os nefários do convívio na urbe ideal, como empecilho para a edificação da cidade excelente da Terra sem Males, semelhante a Platão em sua obra A República, privilegiando as características que denotam nobreza em cada indivíduo, bem como zelando pela sua constituição física, o que visa à educação em sua integralidade, condutora dos entes à Verdade. A elucidação das características de tipos perigosos à excelência da urbe perfeita, como a Paidéia Poética que salva os leitores de condutas que comprometem sua Arete, vai ao encontro da constituição simétrica dos indivíduos da polis ideal platônica, tendo na explicitação dialética, a proposição de que essa mesma cidade perfeita pode, dificilmente, ser corrompida, a não ser que os chefes da cidade não gerenciem, de maneira adequada, a formação das novas gerações, respeitando a circularidade que existe em qualquer âmbito da vida, em que tudo tem um período de duração. Prossegue com a orientação de que tal ameaça inscreve-se na ausência de controle concernente à geração de filhos em momentos inoportunos, não buscando no modelo de geração divina o número perfeito que delimita tal procriação, mas atentando para o cálculo da 


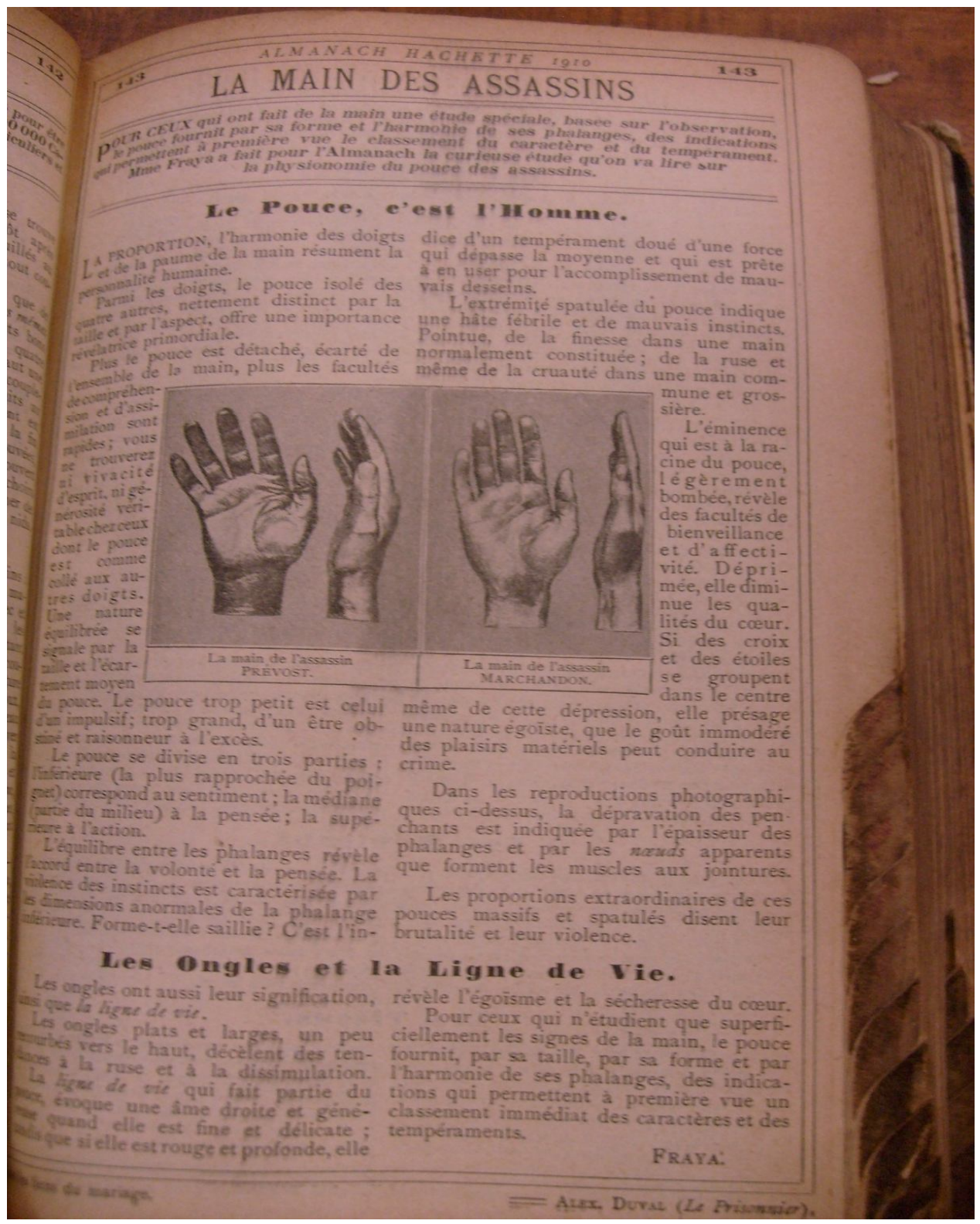

geração humana que segue o raciocínio do primeiro número nas multiplicações dominantes e dominadas, apresentando três termos e quatro limites, tornando-se iguais e desiguais, aumentando ou diminuindo, demonstram que todas as coisas são correspondentes e racionais umas em relação às outras. Assim, o diálogo continua por meio da consideração de que se a 


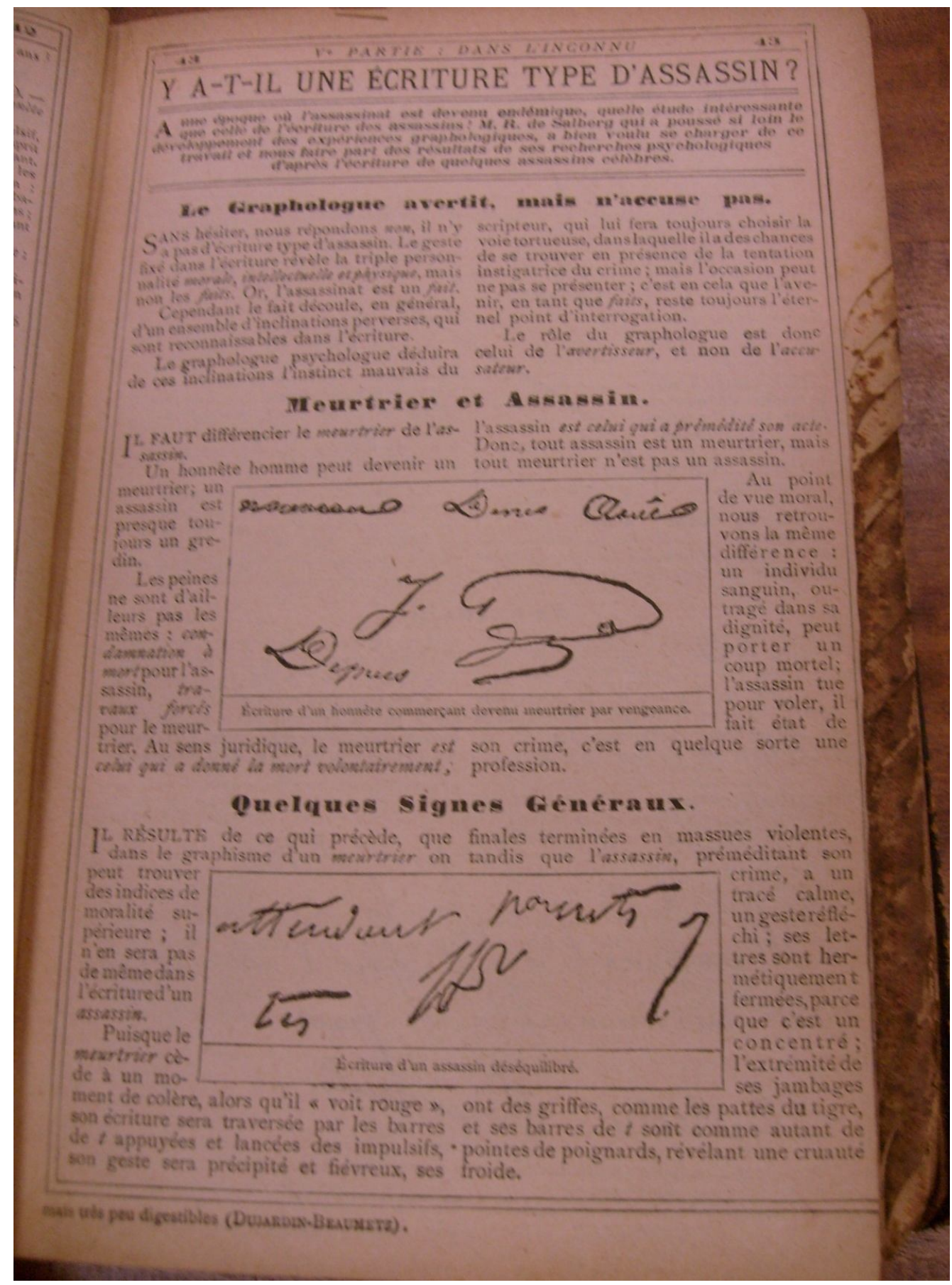

mulher casa-se com o número cinco, quando multiplicada três vezes, produzirá duas harmonias, uma delas será costituída de um número exatamente igual e de cem vezes cem vezes, enquanto que a outra é, de um lado, equilátera e, de outro, retangular, com um lado de cem multiplicado pelas diagonais racionais de cinco, a cada uma faltando um, ou de diagonais 


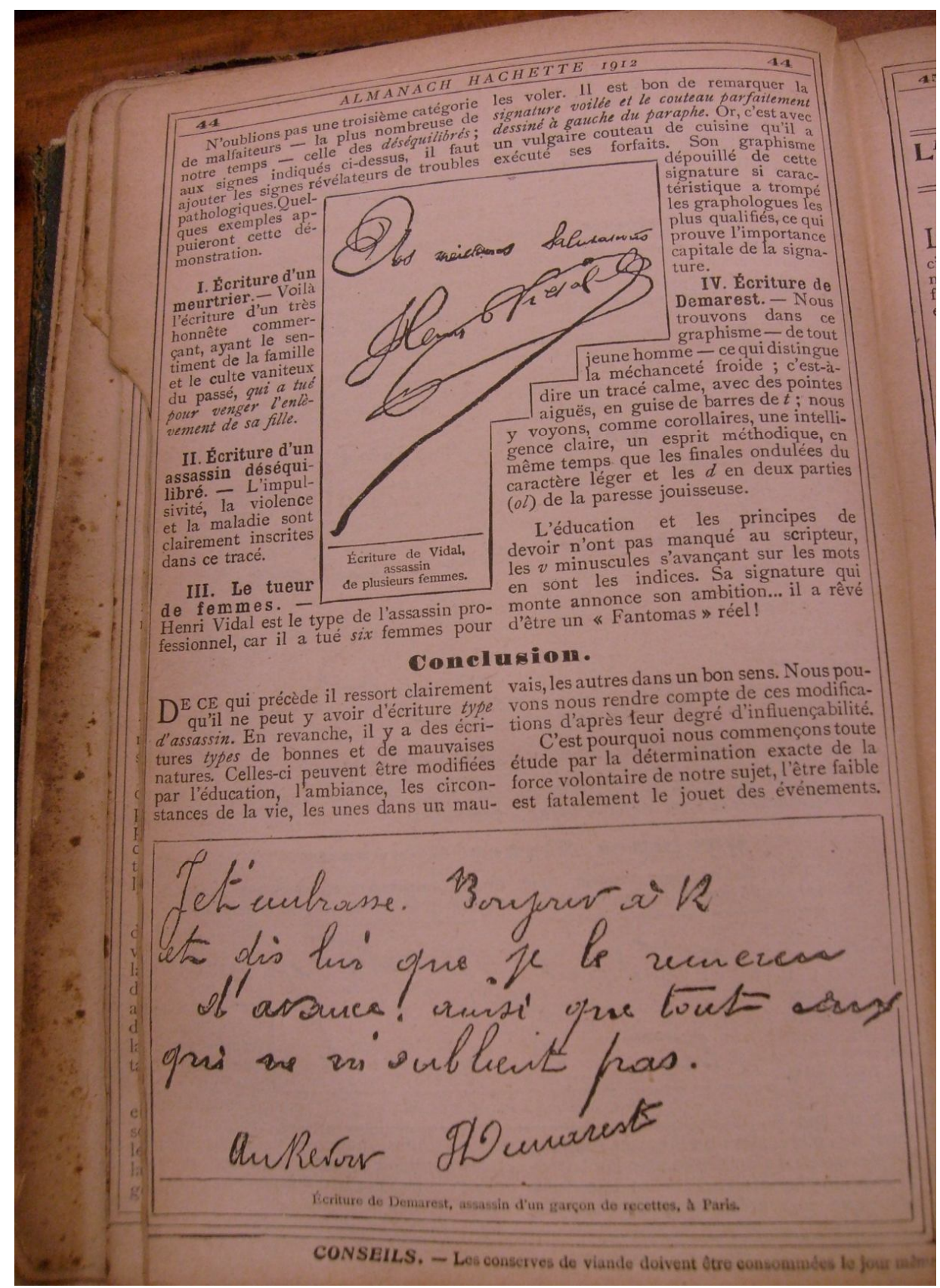

irracionais às quais faltam dois e de cem multiplicado pelo cubo de três. Tendo em vista todo o cálculo geométrico exposto, Sócrates alerta Gláucon para o fato de que se não considerado pelos guardiões para determinação dos melhores e piores nascimentos, fazendo com que as noivas se unam aos noivos em período impróprio, nascerão dessa aliança, filhos em nada bem dotados pela natureza e pela fortuna ${ }^{47}$. Toda a explanação didática e geométrica para geração 
de novos habitantes da polis harmônica, a fim de que sua constituição não seja corrompida, assemelha-se à Paidéia de almanaque, que busca na orientação dos leitores no que concerne a sua Arete, a formação não pelo cálculo, mas por meio de exemplos de má conduta a não serem seguidos, além do cultivo nas artes e nos difrentes saberes, para que novas gerações ou habitantes ainda presos nos grilhões da falsa aparência moderna, tenham sua alma liberta para a verdadeira contemplação do ser, traduzida pelo Sublime do melhor dos mundos possíveis.

Ora, a mimesis do contexto moderno, cujas anomalias genéticas e as externas ao organismo estão alicerçadas em uma orientação para a erradicação dos vícios que comprometem a formação da população - denunciatória pelo engendro da cidade da excelência - sendo considerado nocivo todo aquele que não condiz com os padrões do modelo de Homem representativo de uma raça idônea, pura e forte, tendo no discurso o questionamento de como um tuberculoso, um falido ou um alcoólatra podem ser representativos de uma nação imponente, a elucidação do Ideal de Arete buscado, mas alcançado apenas no microcosmo místico-poético de almanaque. Se na Belle Époque a eugenia buscava um modelo de homem com caracteres físicos, orgânicos e morais ideais, cujos traços rompedores de tal protótipo eram logo classificados como permissivos à humanidade, tal prática é delatada e oposta à da Paidéia Poética de almanaque, haja vista que pela recuperação dos entes em seus estabelecimentos terapêuticos, semelhante às ilhas já mencionadas do Pays D'Utopie, os leitores têm orientação para o alcance da Verdade, tendo no desenvolvimento da Arete pela Poiésis, a salvação para os males da modernidade, dentre eles o exemplo pedagógico do assassino a não ser copiado e a ser recuperado. Essa classificação do contexto histórico em questão, segundo Darmon, entre homens sadios e degenerados deu-se pela identificação de traços anatômicos que generalizavam tais indivíduos, como um crânio anormal, sem regularidade e harmonia, que denunciava assassinos, a relação entre o volume da massa cerebral e o grau de inteligência do indivíduo, colocando os negros em posição inferior aos europeus e aos caucasianos, os traços do rosto, a chamada fisiognomonia, que procuravam esclarecer os segredos da alma e da inteligência, entre outros ${ }^{48}$. É, pois, como resposta a tal barbárie ou denúncia da massa ainda caótica da modernidade, que a poética de almanaque edifica anualmente a cidade ideal resguardada do Tempo Profano, característico dos vícios, paixões e mazelas do mundo moderno, educando verdadeiramente seus leitores para a excelência.

$48 \quad$. Darmon, 1991, pp. 57 e 72. 
Como elucidação de indivíduos da modernidade cuja Arete não foi desenvolvida, mas também como lisibilidade das mazelas sociais de então e de seu total descaso inscrito em diagnósticos disparatados, tem-se na mão característica de um assassino, decorrente do estudo de Mme Fraya que aponta na forma e na harmonia das falanges do polegar a explicação para a criminalidade, bem como a apresentação, a título de exemplo, como defesa para sua tese, das mãos de dois assassinos Prévost e Marchandon. Diante disso, o estudo começa por definir a personalidade humana por meio da proporção, harmonia dos dedos e da palma das mãos, o que atenta para o fato de que quanto mais o polegar for desprendido ou separado do todo, mais as faculdades de compreensão e de assimilação serão rápidas. No entanto, alerta para os indivíduos que apresentam o polegar praticamente colado nos outros dedos, sinal de ausência de generosidade verdadeira, e também aqueles cujo tamanho exacerbadamente pequeno denuncia a impulsividade e, o demasiadamente grande, a obsessão e o excesso de racionalidade. Assim continua o estudo, apontando para a divisão, em três partes, do polegar, l'inférieur correspond au sentiment, la médiane à la pensé et la supérieure à l'action. Após a explanação sobre as características das partes do polegar indicando sentimento, pensamento e ação, a análise chama a atenção para as imagens das mãos dos assassinos, que apresentam a inclinação para a depravação como decorrência da espessura das falanges e dos nós aparentes que formam os músculos junto às articulações. Sendo assim, pela simples caracterização do polegar em relação ao conjunto harmônico das mãos, tem-se o diagnóstico sobre a índole, que indica nas proporções extraordinárias dos polegares maciços e espatulares das figuras, a explicação para a brutalidade e a violência dos assassinos.

Semelhante ao cálculo geométrico platônico e à simetria que representou, em vários momentos da história, as temáticas do Belo e do Bom, observa-se na elucidação do Homem que não adquiriu a Arete, o assassino, a representação do indivíduo moderno não harmonioso, inclinado para os vícios que não lhe permitem alcançar a Verdade, tendo no mito da caverna e na alegoria do sol, a explicitação da ausência de conhecimento do mundo das Idéias, sendo a Poiésis a sua condutora. Ora, é por meio do diálogo socrático, traduzido pela Paidéia Poética de almanaque, que os leitores têm o segredo para alcançar o método do logos que guia a uma conduta reta e libertadora, ou seja, a Poésis que os levam ao conhecimento do Bem - base de cada uma das virtudes almejadas tanto por Platão, quanto pela cultura para a excelência de tais livros herméticos - de seu ser interior e da verdadeira Beleza do mundo. Nessa perspectiva, a volta aos mitos garante a salvação dos leitores do Tempo Profano da modernidade, tendo na elucidação da saída da caverna e da aquisição da visão translúcida para 
enxergar a Verdade, como metáfora da luz do sol que possibilita ver com maior nitidez, a orientação para que a alma atinja a lucidez gerada pela Arete que resgata o Homem da escuridão da ignorância. Logo, a conquista do mundo inteligível dá-se por meio da comparação que Sócrates faz da visão, que possibilita enxergar as cores dos objetos de forma verdadeira, a partir de um terceiro elemento, a luz, gerada pelo deus, sol. Prossegue elucidando que ele não representa a visão, nem tampouco, que ela se dá no lugar que se imagina, nos olhos, mas na metáfora que se inscreve na paternidade do sol concernente ao bem, cuja relação no mundo inteligível com o conhecimento e as Idéias é a mesma que o sol tem, no mundo visível, com a vista e as coisas visíveis. Menciona ainda que se os olhos não se voltam mais para os objetos em cujas cores a luz do dia se fixa, mas para as estrelas noturnas, eles têm sua visão comprometida, parecendo quase cegos, como se neles não houvesse tal faculdade. Desse modo, continua com a explanação da iluminação do sol como responsável pela nitidez da visão, tendo nessa relação a caracterização da alma quando se apóia na verdade, mas quando se mistura à escuridão, ao que vem a ser e que perece com o decurso do tempo, tem sua visão nebulosa, assemelhando-se ao indivíduo que não tem inteligência. É justamente esse caminho buscado pela Paidéia Poética, o transporte dos leitores dos almanaques ao Sublime, tendo ainda no mito da caverna, que traduz a libertação do Homem dos grilhões da aparência, a salvação para os males do mundo moderno. Assim, o mito inscreve-se no Livro VII, comparando a natureza do ser concernente à educação ou à falta de educação com a experiência de homens habitantes de uma morada subterrânea, cujo acesso dá-se por uma abertura que envolve toda a extensão da caverna que está voltada para a luz. Nesse ambiente vivem desde a infância, com grilhões nas pernas e no pescoço impedindo-os de olhar para frente. É dessa maneira que lhes chegam, de longe, a luz de uma fogueira que arde, atrás deles, num local mais alto. Entre a fogueira e os prisioneiros há uma espécie de caminho ao longo do qual se eleva um pequeno muro semelhante ao tabique que separa os mágicos de seus espectadores. Ao longo desse pequeno muro passam homens carregando toda sorte de objetos, alguns falando e outros em silêncio, desenhando sombras projetadas pela fogueira na parede da caverna, vultos que parecem realmente verdadeiros para tais prisioneiros, em comparação a outros objetos reais. Sair da caverna indica a libertação dos grilhões e a cura da ignorância, no entanto, exige tempo para se acostumar com a luminosidade intensa incidida nos objetos antes refletidos por sombras, para então, ver o que está no alto. Partir dos vultos, em seguida para as imagens dos homens, animais, dentre 
outros, reproduzidos na água, passando pela sua visão real, até, por fim, voltar o olhar para contemplar o que está no céu com mais facilidade, e durante o dia, o sol e a sua luz ${ }^{49}$.

É essa mudança do estado de sandice para a verdade que provoca compaixão nos libertos para com os prisioneiros, tendo na dialética platônica a elucidação da Paidéia Poética, sendo a libertação da caverna e a luz do sol a representação salvadora da Poiésis dos males da modernidade, cuja volta à Antiguidade, com seus deuses e heróis, possibilita a conquista de uma nova Criação de homens sábios, sãos e retos, a cada edição de almanaque.

É o que se encontra de forma semelhante no Almanaque Brasileiro Garnier para o ano de 1904, posto que a Paidéia Poética tece a idealização do Homem, cuja tradução simbólica dá-se na beleza do corpo para o desenvolvimento de sua Arete, por meio do texto Correcçao de Narizes, que discorre sobre a questão da cura para várias imperfeições com o método desenvolvido pelo Dr. Gersuny, cirurgião de Viena. Nesse, o doutor aproveita as propriedades da vaselina para solucionar o comprometimento da pronúncia produzido por um lábio leporino mal operado. O discurso assegura tratamento para tal problema, que prejudica a pronúncia das palavras, eliminando a "cicatriz viciosa do labio leporino". A partir da aplicação da vaselina em lábios leporinos e de seus resultados positivos, o método procura eliminar outras deformidades, como "a correcção dos narizes anormaes", “Tentou-se, e o existo foi completo. Os casos multiplicaram-se, sendo facil reconhecer a feliz transformação obtida'. Diante de tais exemplos como mimesis da realidade circundante, elucida-se novamente a presença da busca pelo padrão ideal de corpo na sociedade em questão, cuja utopia da perfeição corpórea, simétrica, que visa à formação de seus leitores na sanidade e na nobreza, liame sempre presente, dá-se apenas na polis da excelência do melhor dos mundos possíveis de almanaque.

As correções apresentadas pelo Dr. Gersuny de Viena e incorporadas no material brasileiro, remete à apropriação de tal teoria da perfeição, mesmo que de forma diferenciada, agora para utilização em cirurgias de nariz quebrado ou de lábio leporino, para adequação da pronúncia, da respiração, dentre outros. Pela estetização do mundo circundante, observa-se a garantia da fisionomia ideal, do Belo buscado nos ginásios gregos, na feição semelhante a dos deuses, "Os effeitos da injecção são rápidos; o operador depois só tem que modelar debaixo da pelle a vaselina ainda semi-liquida para dar ao nariz a forma definitiva que deseja', o que ainda garante a ausência de qualquer inflamação ou intoxicação e afirma que se trata de uma

49 .Referente ao Mito da Caverna, ler A República, 514 a, 515 a, b, c, d, e, 516 a, b, c, d, pp. 267, 268, 269 e 270 e à Alegoria do Sol consultar o livro VI, 507 e, 508 a, b, c, d, pp. 258, 259 e 260. 
bela conquista da cirurgia moderna, uma espécie de nova Criação, não a partir do barro, mas da "vaselina mágica" que possibilita a conquista da Plenitude em consonância com feitura anual de almanaque.

No microcosmo quimérico, o leitor do Almanaque Brasileiro Garnier obtém, por meio da Paidéia Poética, fórmulas para atingir a beleza ou a perfeição dos deuses, por meio das orientações para eliminar não apenas as distorções físicas, mas aquelas que estão inscritas, sobretudo, na alma enferma decorrente das problemáticas da modernidade, que rompem com o arquétipo ideal do melhor dos mundos possíveis. Desse modo, a modelagem do nariz anormal e do lábio leporino produz um corpo perfeito e saudável, como uma espécie de engendro de novos e belos entes na urbe harmônica, a partir da matéria preexistente, os seres enfermos mais no espírito do que no próprio físico. Logo, o leitor é orientado sobre os cuidados com o corpo por meio do esteticamente perfeito, corrigindo traços que não lhe aprazem, concomitantemente, é alertado, pela Poiésis, sobre a falsa aparência que encobre a verdadeira beleza do mundo. Sendo assim, pode usufruir já nos primeiros decênios do século XX, de intervenções cirúrgicas para correção de imperfeições, não modelando ou preenchendo partes do corpo com botox, como nos procedimentos hodiernos das clínicas de estética, mas sim com vaselina branca (mistura de parafina sólida e parafina líquida) aquecida e injetada com uma seringa de Pravaz. 


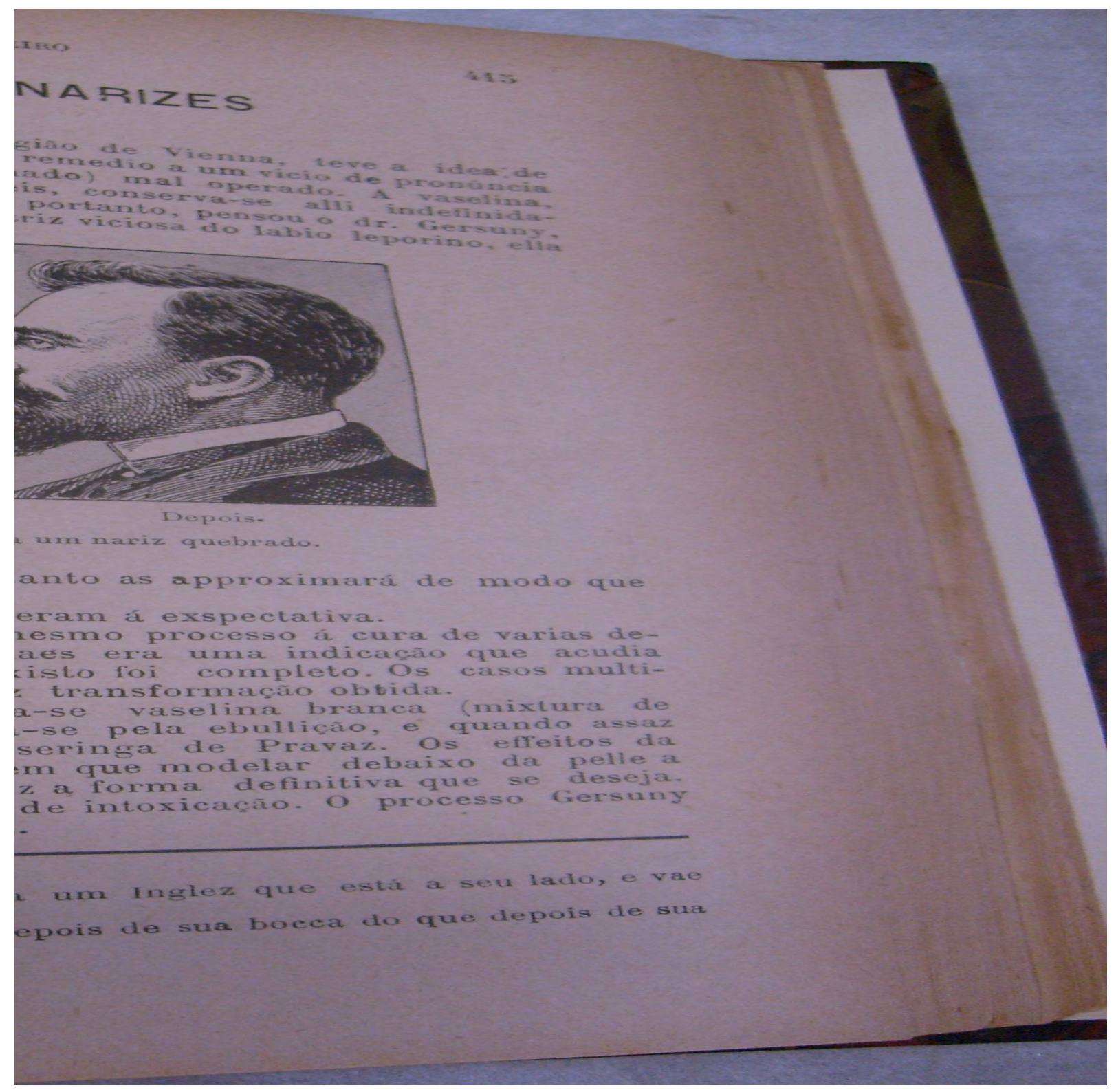

É por meio da Paidéia Poética que os leitores alcançam o Sublime, ou melhor, corrigem as imperfeições e conquistam o Belo que não se esvai com a inexorabilidade do tempo, direcionando ao que Platão elucida sobre os filósofos-reis, que ao conviverem com o que é divino e ordenado, também se tornam ordenados e divinos, na medida do possível para um homem, sendo responsáveis como pintores, por desenhar e seguir o modelo divino a fim de edificar uma cidade feliz. Tal tarefa increve-se na atitude de tomar a cidade e os costumes dos homens, como em um quadro, a fim de limpá-los de suas mazelas, sem se ocupar com cada pessoa individualmente ou com a escrita de leis, mas de receber tal urbe limpa ou de asseá-la. Seguidamente, colocam-se ao trabalho, atentando para aquilo que, por natureza, é justo, belo, 
temperante ou de atributos semelhantes, e para aquilo que produzissem no meio dos homens, mesclando e temperando cores a partir de seus ofícios para atingir a tez humana, adotando como alicerce aquilo que, quando presente entre os homens, Homero chamou de divino e análogo aos deuses ${ }^{50}$. É, pois, a partir desse poder de transformação do profano em sagrado, de moldar a cidade e seus cidadãos a partir dos arquétipos divinos, que a oferta do Belo é distribuída nos almanaques, modelando a tez humana com uma pigmentação divina por meio da Poiésis geradora da Plenitude.

Essa busca incessante pelo corpo ideal é observada ainda no Almanaque Brasileiro Garnier para o ano de 1911, no anúncio sobre o Methodo Desbonnet, de um professor francês, cuja propaganda no almanaque brasileiro, com endereço em Paris e indicações quanto a possível interesse na fundação de sucursais no estrangeiro, reforça a leitura comparativa, Brasil-França, aqui desenvolvida. O método do professor Desbonnet é mais um exemplo de ligação direta com a cultura francesa, típica da chamada Belle Époque, posto que a mensagem dirige-se aos brasileiros que chegam à Paris e podem usufruir da ginástica para o Belo, cuja eficácia é notável, proporcionando-os uma saúde perfeita e um corpo invejável. Sendo assim, nas Escolas da Cultura Physica do Professor Desbonnet, em Paris, 48, Faubourg Poissonnière, para homens, mulheres e crianças, tem-se acesso ao corpo sonhado, à utopia do corpo ideal. Nesse, observa-se nitidamente a preocupação com o corpo, uma espécie de Paidéia gímnica para adquirir a perfeição e a harmonia corporais, direcionando à Primeira Grécia, que tinha na cultura física dos ginastas o modelo para a conquista da excelência. Decorrente desse período, a Arete, termo que elucida o ideal de educação da época, como já mencionado, segundo Jaeger, caracterizaria-se na seguinte proposição, "Vigor e saúde são a arete do corpo; sagacidade e penetração, a arete do espírito". Tal explanação representa o eu não como sujeito físico, mas como tradução do mais alto nível de perfeição do Homem que o espírito pode tecer e que todo indivíduo nobre almeja alcançar. Apenas na mais alta valoração desse $e u$, em cuja arete inscreve-se, é capaz de "produzir beleza", posto que aspirar à "beleza" (que para os Gregos expressa tanto a nobreza quanto a eleição) no sentido de adquiri-la, é não desprezar nenhuma ocasião para alcançar a mais alta arete $^{5 l}$. É, pois, na preocupação com a integralidade do Homem, cuja beleza do corpo está em consonância com a nobreza do espírito, considerando a ginástica e a música para a formação, como a representação da cultura grega antiga, que se traduz na figura do atleta olímpico como arquétipo da excelência

$\begin{array}{ll}50 & \text { República, } 500 \mathrm{~d}, 501 \mathrm{a}, \mathrm{b}, \mathrm{pp} .248-249 . \\ 51 & \text {. Jaeger, p.35. }\end{array}$ 


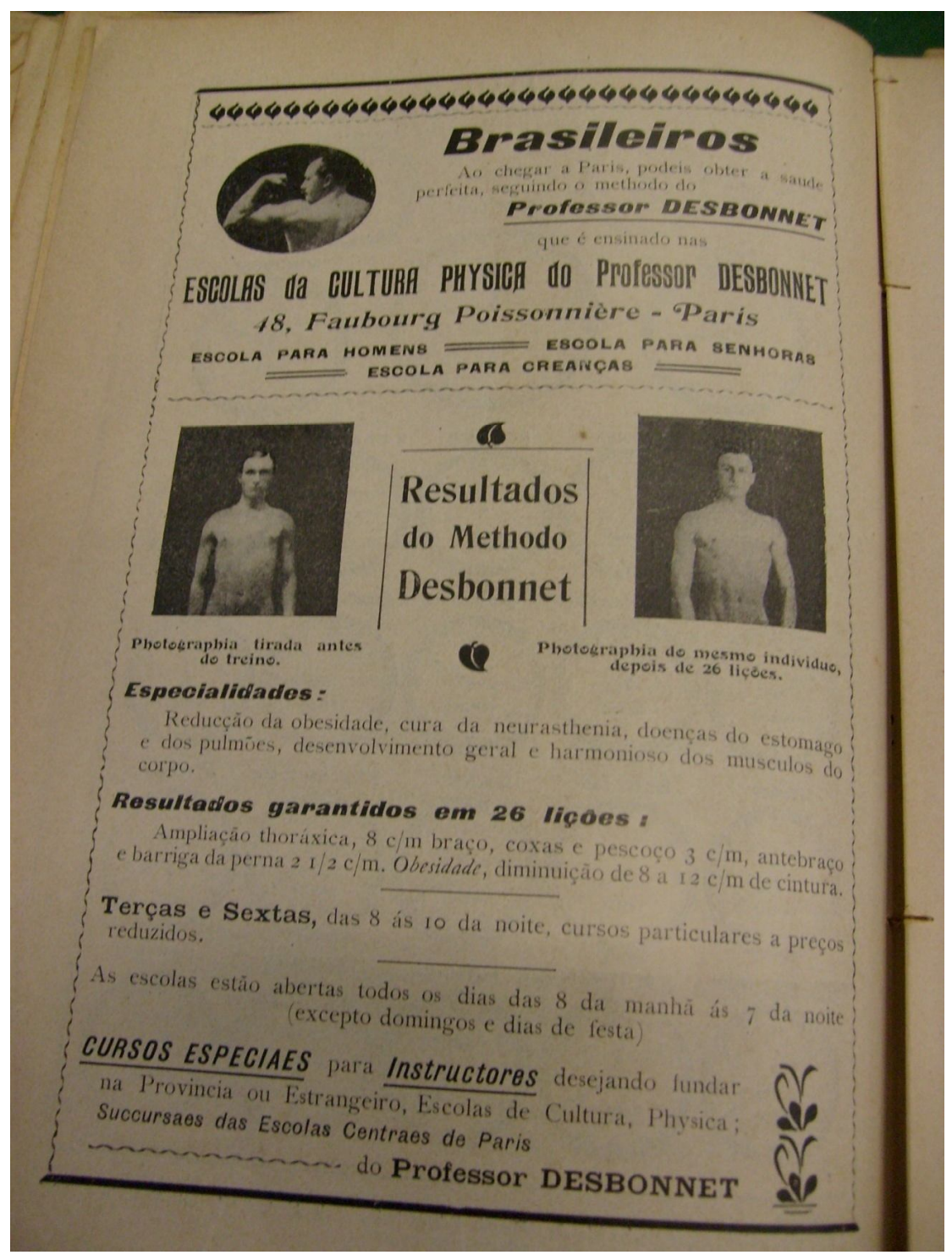

por meio do vigor nos ginásios e nas corridas, a caracterização do ideal de corpo ansiado, a elucidação da mais alta arete. Nessa perspectiva, é relevante salientar o universo mítico do qual o berço da ginástica é oriundo, estando em consonância com a miticidade cara aos almanaques, que salva os leitores do Tempo Profano da modernidade, tendo nos exercícios gímnicos (gymnos do grego - nu) praticados nos gymnasios, sob os auspícios do deus Apolo, deus da juventude bela e forte, da música e da poesia e na imagem de Hermes, deus de beleza juvenil e atlética, o liame que permitia o desenvolvimento global do Homem. É, pois, na Grécia que se tem a origem dos Jogos Olímpicos, cujas competições deram-se 293 vezes 
durante quase 12 séculos (776 a.C - 393 d. C), sítio que ainda tinha como cerne concernente à ginástica, a educação corporal em Atenas e a preparação para a gerra em Esparta ${ }^{52}$.

Tamanha importância que a ginástica tinha para os gregos da Grécia antiga direciona ao que Platão elucida na República sobre a educação dos guardiões que se dava por meio do estabelecimento na cidade de uma medicina e de um corpo de juízes para zelar pelos cidadãos, tendo na díade ginástica e música o caminho para não necessitar da prática médica e dos aconselhamentos dos juízes. Prossegue com a proposição bastante significativa que diz respeito à educação pela música direcionada aos cuidados da alma e pela ginástica relacionada ao cultivo do corpo, que deve seguir o viés da harmonia para que desenvolva a integralidade humana, posto que os indivíduos que dão ênfase à ginástica e olvidam a música, podem pender para os opostos de rusticidade e dureza ou brandura e polidez. O diálogo continua reforçando a importância das duas qualidades nos guardiões, tendo na consessão dos deuses das duas artes, a ginástica e a música, harmonizadas, a conquista de um nível apropriado de tensão e relachamento. Assim, o homem capaz de atentar para a melhor consonância entre a música e a ginástica é considerado o mais sensível às musas e mais harmonioso, em alto grau comparado ao que afina as cordas de um instrumento ${ }^{53}$.

Tendo em vista a educação pela música e pela ginástica para os guardiões, desde a mais tenra idade como menciona ainda o diálogo platônico, tem-se o cotejo com as imagens que se assemelham e exemplificam a eficácia do método Desbonnet nos almanaques, por meio de um determinado homem que dele se utiliza, o que lhe permite obter resultados surpreendentes após 26 lições, como uma espécie de antes e depois do treino que elucida a veracidade do processo. A propaganda ainda assegura o leitor de que apenas após 26 lições o individuo terá resultados garantidos, como: "Ampliação thoráxica, $8 \mathrm{c} / \mathrm{m}$ braço, coxas e pescoço $3 \mathrm{c} / \mathrm{m}$, antebraço e barriga da perna $2 \frac{1 / 2}{\mathrm{c}} / \mathrm{m}$. Obesidade, diminuição de 8 a $12 \mathrm{c} / \mathrm{m}$ de cintura.', além de apresentar os seguintes benefícios: "Reducção da obesidade, cura da neurasthenia, doenças do estomago e dos pulmões, desenvolvimento geral e harmonioso dos musculos do corpo", ou seja, um método eficaz considerando os resultados significativos, bem como a garantia de um desenvolvimento harmônico dos aderentes, visto que cura desde doenças pulmonares e estomacais, passando pelo tratamento da depressão e chegando ao tão sonhado corpo ideal, um verdadeiro bálsamo para todos os males.

52 . Artigo de Elizabeth Paoliello intitulado "O Universo da Ginástica" do Grupo de pesquisa em Ginástica Geral FEF - Unicamp, p. 2.

53. República, 410 a, c, d, 411 c, 412 a, pp. 121, 122, 123 e 124. 
Tal método prodigioso, que vela tanto pelo corpo quanto pelo espírito, pode ser adotado tanto na Província quanto no Estrangeiro, havendo Cursos Especiaes para Instructores que desejem fundar Escolas de Cultura, Physica na Província ou no Estrangeiro, filiais das Escolas Centrais de Paris, ou seja, negócio extremamente rentável, pois garante o lucro tanto pelos estrangeiros que chegam à Paris, quanto por aqueles que almejam estabelecer sucursais em seu país. Ora, a busca pela Beleza Apolínea no século XX salva os leitores de almanaque do Tempo Profano, tendo no padrão ideal de corpo e melhoramento da raça no que tange à falta de conhecimento da Verdade, semelhante a polis harmônica de Platão, a conquista e resgate do Belo em meio ao Feio caracterizado pelas mazelas da modernidade, consequentemente, o cessar simbólico da inexorabilidade do tempo e a correção das deformidades da alma no microcosmo engendrado pela Poiésis. Logo, o padrão de corpo saudável e perfeito do século XX no Brasil, visto que a propaganda do método Desbonnet data de 1911, certifica de que as Escolas de Cultura Física têm o papel de educar os indivíduos para a excelência, o que verdadeiramente é possível apenas no melhor dos mundos possíveis de almanaque, posto que a feitura poética anual organiza a matéria preexistente, ou caótica do mundo circundante, para formação de cidadãos nobres e sadios a fim de viverem na urbe ideal ausente dos males da modernidade.

É interessante ressaltar que a busca excessiva pelo corpo ideal, nos primeiros decênios do século XX, representa a eterna angústia pelo decurso do tempo e aproximação da finitude, bem como da busca obsessiva pelo Belo desde os primórdios, cujo in illo tempore representa a verdadeira salvação mítico-poética para tais temores reatualizados na modernidade:

Outra cultura ainda inspira o novo modelo, o de uma ginástica julgada suficientemente legítima para se tornar obrigatória nas escolas públicas francesas, a partir de 1880, e nas de diversos países europeus e estados norteamericanos. Cultura complexa, para dizer a verdade, hoje bem conhecida, lentamente elaborada no século XIX, reflete um novo universo de dimensão e eficácia físicas, misturando referências biológicas com as das máquinas, dos motores, das zootecnias, e também as do trabalho sobre a pessoa. Ela multiplica os exercícios, fixa os resultados. Cultura complexa ainda porque focaliza as inquietações sobre as formas vindouras da espécie, na segunda metade do século XIX: as ameaças do confinamento nas cidades, o trabalho das crianças, as pressões da indústria. Ela pretende responder às angústias do "enfraquecimento da espécie", às "causas da degeneração dos povos civilizados", todas as "fraquezas" de onde as elites imaginam inesgotáveis pedagogias.( VIGARELLO, 2006, p.127)

A partir da citação, tem-se a elucidação das inquietações do homem moderno, que tem no método francês a salvação simbólica para os males que o circundam, cujo padrão de beleza do anúncio representa o Belo oriundo dos deuses e atletas olímpicos, como resgate do 
Tempo Sagrado inscrito na robustez divina decorrente da amplidão torácica idealizada pelo professor Desbonnet. A estetização do mundo moderno engendra, pela propaganda inserida no microcosmo místico-poético, a garantia do aumento de volume do tórax como marca da semelhança com os deuses, mencionada por Platão e arquétipo imitável pelo Homem, o que possibilita a transformação dos abdomens extenuados em massa corpórea vigorosa característica do Homem Belo e Bom.

Uma anatomia desenhada com as tintas sagradas para uma nova Criação é então seguida simbolicamente no decorrer do século XIX e início do XX, sendo o método do professor Desbonnet a garantia de "desenvolvimento geral e harmonioso dos músculos e do corpo", proporcionando, ao final das 26 lições, uma amplitude torácica considerada digna dos deuses:

(...) Isso sugere mais do que nunca um avanço do busto, um perfil preciso de corpo: o "tipo torácico" se opunha ao "tipo abdominal". O torácico revelaria uma força combustível, o abdominal revelaria uma fraqueza de músculo e energia: "A amplidão torácica é o problema mais importante da ginástica de desenvolvimento". E tanto que se acrescentam outros efeitos morfológicos à "frouxidão" do tipo abdominal: o arqueamento excessivo dos lombos por deficiência excessiva do "ventre", a "curvatura dorsal", expressão nova dos anatomistas do fim do século XIX, esses rins abusivamente encovados, sinais de fraqueza mais do que de beleza. (VIGARELLO, 2006, p.127)

Tendo em vista a busca pelo perfil da excelência oposto aos sinais de curvatura dorsal representativos da fraqueza do Homem, no "tipo torácico" do fim do século XIX e meados do XX, observa-se a tradução do retorno ao mesmo protótipo robusto da Grécia Antiga que buscava a semelhança com os deuses, tendo no liame música e ginástica também ministrado nas liçães de almanaque, a elucidação do desenvolvimento integral humano, tomando como exemplo pedagógico a não ser seguido, os entes não-virtuosos, como o assassino, em consonância com a Beleza assegurada tanto pelo doutor Gersuny, quanto pelo método do professor Desbonnet, a representação da arete alcançada, por meio da Poiésis, que direciona o ser para o Divino no melhor dos mundos possíveis de almanaque.

Se para cada gymnasio correspondia o patronado dos deuses Apolo e de seu irmão Hermes na antiguidade, tem-se na polis da excelência proteção semelhante, dos santos para cada atividade e cada dia do mês, dos astros e signos que possibilitam a leitura do presente e do porvir, bem como dos homens dotados de poderes sobrenaturais e das práticas relacionadas ao universo místico, que protegem os leitores dos males da modernidade.

O ideal de beleza dos almanaques também se inscreve no sagrado, cuja busca pelo corpo perfeito traduz-se pelo combate à obesidade, tendo na simbologia do modelo divino, a 
representação da volta à temática do Belo que se inscreve no corpóreo da eterna juventude dos deuses, tendo na perfeição dos atletas gregos que, por sua vez, buscavam tal arquétipo, o viés para alcançar o peso prototípico, com o produto Iodhyrine do Dr. Deschamp:

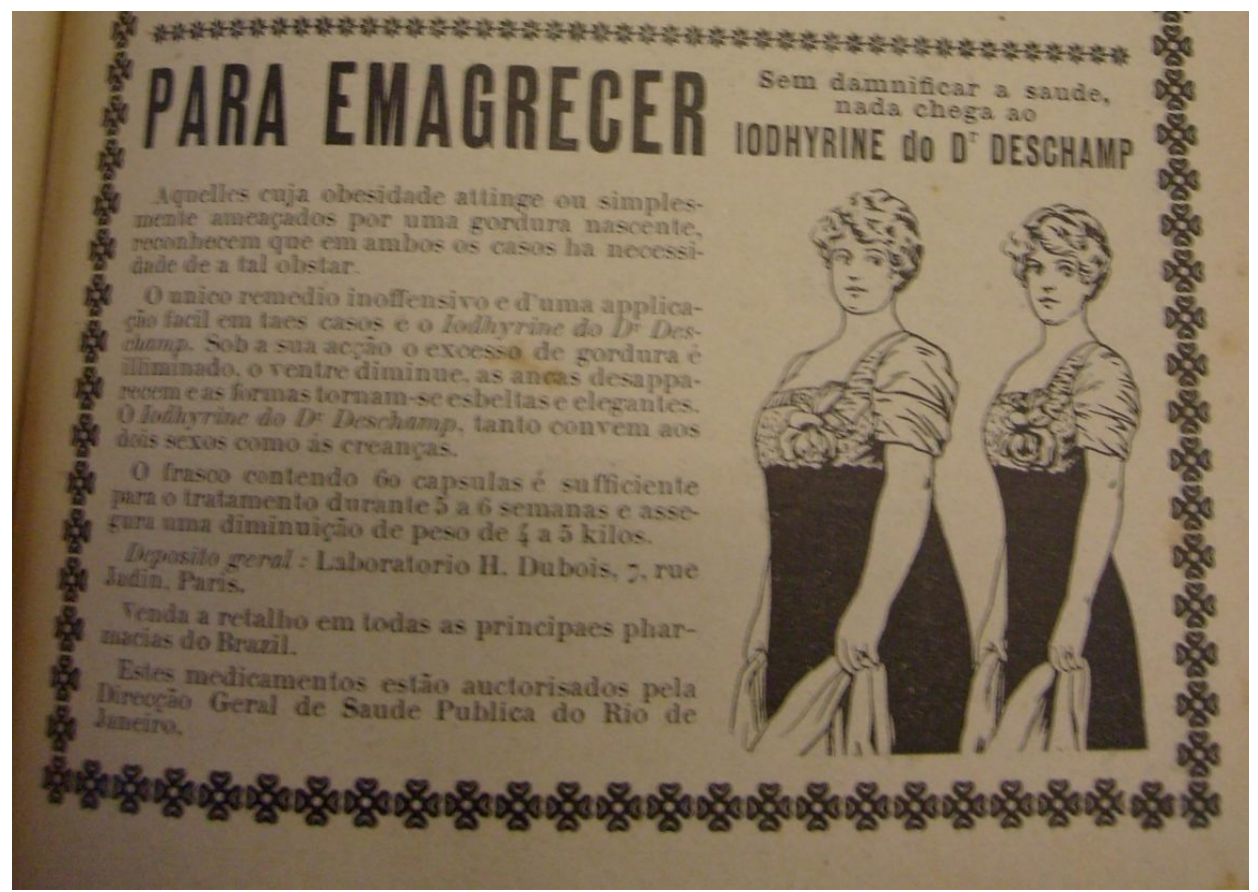

O culto ao Belo não se dá nos ginásios nem em templos sagrados, mas no Almanaque Brasileiro Garnier para o ano de 1911, tendo na receita para atingir a perfeição do corpo, que permite a correção do excesso de gordura "Para Emagrecer Sem damnificar a saúde', a garantia de exclusividade do produto Iodhyrine do Dr. Deschamp, pois nenhum outro apresenta a sua eficácia, curar tal imperfeição sem comprometer o bem-estar, ou seja, há uma espécie de preocupação com a integralidade humana, traduzida indiretamente, no liame já mencionado, corpo e espírito, a recuperação simbólica do Homem harmônico. No lugar da representação das oblações e preces feitas aos deuses antes das competições ou nos ginásios sob a tutela divina, tem-se no remédio, inserido no microcosmo quimérico e patronado pela mística de almanaque, a permissão sagrada para o culto ao Belo, possibilitando tanto àqueles que possuem excesso de gordura desde a nascença, quanto àqueles que assim o ganharam em um determinado momento, a eliminação da massa adiposa e a conquista da harmonia e da proporção ansiadas desde a Grécia Antiga.

É na cidade da excelência que se dá o alcance do arquétipo divino, pelo medicamento Iodhyrine, encontrado em Paris, número 7, Rue Jardin, no Laboratório H. Dubois, 
corroborando o diálogo Brasil-França aqui analisado, havendo uma espécie de intercâmbio quimérico de almanaquias, fazendo entre as polis harmônicas, Paris e Rio de Janeiro, uma passarela sagrada, para os passantes flanarem e exibirem seus belos corpos, edificada com o ouro em pó advindo das riquezas de tais sítios maravilhosos, tecidos pelo flâneur-poeta. Ora, é na Paidéia Poética que os leitores brasileiros e franceses têm a dieta para conquistar o corpo ideal, sendo ministrada pelo doutor francês que prescreve, tanto na França quanto no Brasil, receitas cujo Belo é o medicamento mais importante em detrimento dos outros, tendo no teor místico dos almanaques, a simbólica da cura do corpo e do espírito acometidos pelos males da modernidade. Tal terapêutica onírica é traduzida "pela pedagogia das doenças" como Platão denomina a Medicina, empregada pela Poiésis que sara a cegueira e outras enfermidades que comprometem a visão da verdadeira Beleza do mundo.

Desse modo, o peso ideal pode ser alcançado por meio do uso do medicamento Iodhyrine do Dr. Deschamp, o único "remedio inoffensivo e d'uma applicação facil", que elimina o excesso de gordura, diminui o ventre, faz desaparecer as ancas e torna as formas esbeltas e elegantes. Não é apenas a mulher que pode fazer uso de tal medicamento, mas também o homem e as crianças, reforçando a Paidéia Poética desde a mais tenra idade, modelo de adelgaçamento das formas também para os infantes. O remédio que tem poder para eliminar o excesso de gordura do corpo é constituído de 60 cápsulas, para tratamento de 5 a 6 semanas, garantindo a perda de 4 a 5 quilos. Nessa busca pelo padrão de corpo perfeito, o espaço doméstico recebe educação adequada para formação da família ideal, condizente com a urbe da excelência, onde pai, mãe e filhos representam a conquista do Belo, em consonância com a saúde da alma, que traduz o modelo familiar para preservação da arete e para a formação das novas gerações. Nesse microcosmo idealizado, o Feio é transformado em Belo, a gordura é combatida como causadora de enfermidades físicas e estéticas, sendo a beleza de uma silhueta perfeita garantida pela pedagogia para a excelência de almanaque, tendo no ideal de corpo, a conquista do in illo tempore, da aparência excelente arquetípica dos deuses. É o que se observa na imagem que acompanha o anúncio, uma mulher acima do peso que faz uso do remédio e se torna assaz elegante, bela e aparentemente saudável, como representação da garantia do medicamento e da Beleza que simbolicamente não perece.

O culto ao corpo, por conseguinte, à beleza, pode ser realizado no aconchego do lar, em uma ritualística de intimidade moderna, não mais nos ginásios e santuários de outrora, e adquirido a retalho, ou seja, a varejo em todas as principais farmácias do Brasil, ainda que de origem francesa, sendo um medicamento "auctorisado pela Direcção de Saude Publica do Rio 
de Janeiro', Tal discurso de combate à obesidade, como representação da temática do Belo, é adotado no fim do século XIX, como mais um período em que a busca pela beleza se faz notável, havendo uma espécie de retorno cíclico que reafirma as inquietações do Homem diante do corpo adiposo e da excelência corpórea:

(...) Afirma-se uma expectativa, revelada pelas cartas das leitoras nas revistas de moda, a das mulheres que desejam "adelgaçar certas partes de seus corpos [julgadas] muito pesadas. O tema é tomado como alvo: a obesidade ganha singularidade "feminina", seu perfil se particulariza em relação ao homem. Os quadris, em particular, são mais evocados. O objetivo é "evitar as espessuras nos quadris" ou "o desenvolvimento dos quadris" ou "a invasão dos quadris e da cintura". Os anúncios "adelgaçadores", cuja presença cresce na publicidade do século XIX, também indicam: as pílulas Cardina pretendem "diminuir os quadris, o ventre, adelgaçar o porte", as pílulas Gigartina pretendem "diminuir o queixo, o ventre, os quadris e adelgaçar o porte". (VIGARELLO, 2006, p.131 - 132)

Como prolongamento do discurso do Belo, tem-se nos primeiros decênios do século XX, nos almanaques, a elucidação da busca do ideal de beleza já ansiado na Primeira Grécia, como uma reiteração simbólica obsessiva do Homem de conquistar o Ideal inscrito no Divino, alcance que se dá na urbe harmônica por meio da Paidéia Poética salvadora da alma e do corpo do Caos moderno, pela conquista do Sublime, na idade de ouro atualizada.

É o que se nota de forma semelhante no Almanach Hachette para o ano de 1910, a busca pelo corpo ideal e o combate à obesidade pelos Sels Naturels Cuquets, assegurando os leitores sobre o bálsamo para a cura do sobrepeso e para emagrecer, Cure de l'obésité et Pour Maigrir. Tal promessa de eliminação da gordura, como no almanaque brasileiro, também vem acompanhada de um discurso milagroso, ou seja, de uma cura prodigiosa sem a menor necessidade de esforço, nem ao menos de um regime auxiliatório da terapêutica do Belo, o resultado é garantido e sem risco algum: "Sûrement..., Sans danger, Sans regime”.

A conquista do corpo ideal, no almanaque francês, é garantida pelo tratamento com os Sels Cuquets que agem diretamente no fígado produzindo um fluxo regular da bílis, cuja ação provoca a dissolução da gordura em todas as partes do organismo. Além da eficácia quanto ao combate da obesidade, o uso dos sais certifica ainda a volta da vitalidade e dos nutrientes necessários à saúde do corpo, o que resulta automaticamente no desenvolvimento do tecido muscular, substituindo progressivamente o tecido adiposo. Ainda, o tratamento é de tamanha pujança, que a flacidez natural provocada em um processo de emagrecimento é abolida, a deformação da estética também descartada e o alento quanto a não formação das rugas assegurado: (...) Il n'est pas à craindre la formation des rides, le relâchement et la déformation de l'esthétique. Como no almanaque brasileiro, a conquista do Belo é garantida e 
a sua fugacidade combatida, por meio da eliminação da contra-indicação presente em qualquer processo de emagrecimento, que se traduz na formação de rugas, na flacidez e na deformação da silhueta, havendo ainda, no discurso, uma espécie de preocupação com o desenvolvimento da integralidade dos usuários, posto que os sais não agem apenas na aparência, tornado-a ideal, mas também no organismo que recupera a vitalidade e os nutrientes necessários à saúde, o que remete à díade corpo e espírito da Paidéia Grega, que pela saúde do corpo educava-se a alma para a excelência, cuja harmonia simboliza a conquista do Sublime no microcosmo místico-poético de almanaque.

Outro aspecto importante inscrito no ideal de beleza do almanaque francês é a questão da origem do produto, pois os Sels Cuquets têm um diferencial perante os outros, não é manipulado em farmácias, mas sim extraído de jazidas minerais espanholas "gisements miniers", o que garante a sua exclusividade, além de garantir que se trata de um produto natural Sels Naturels, sem os riscos dos inúmeros produtos químicos existentes nos laboratórios: Les Sels Cuquets ne sont pas une préparation pharmaceutique, ce sont des sels de provenance espagnole - gisements miniers "Sels Cuquets" - leur emploi est sans danger. A conquista do corpo perfeito, que o anúncio oferta aos leitores com a promessa de que os Sels permitem a realização do tão sonhado ideal de beleza ou da cura do sobrepeso, La Cure de l'obésité, dá-se por meio do tratamento parcial que custa apenas 10 francos o frasco e o completo 27 francos. A credibilidade de tal tratamento ainda é reforçada por meio do selo de garantia que aparece ao final do anúncio, a gratuidade quanto à certificação da eficácia e da idoneidade do produto. Assim, a receita para adquirir o Belo tem número e endereço, na Paris da excelência, Faubourg Poissonnière, número 123, mantenedora da quimera de almanaque, pois ainda que tal microcosmo místico-poético seja a estetização do mundo moderno, com informações reais de local de venda, dentre outros, representa a eterna busca da perfeição, o que não condiz com a natureza humana, mas é alcançada pelos leitores por meio da mimesis transformadora da efemeridade em simbólica da perenidade advinda dos arquétipos sagrados, como algo que se repete ad infinitum pela tessitura ininterrupta da Poésis. Como sorte divina que aparece em meio à floresta escura e sem esperança, o sol nascente que traz o Belo, a Beleza vinda dos céus, como a beleza dos deuses, permite o alcance, pela Poiésis, do mundo inteligível platônico ou do Sublime de almanaque, que transforma o sombrio Caos moderno em luz cintilante condutora da Verdade. Logo, o sol que desponta na imagem nasce como estética para o Feio que atinge os leitores do Almanach Hachette, a obesidade representativa 
das mazelas circundantes, cujo tratamento e eliminação encontram-se nos Sels Cuquets travestidos de poeticidade.

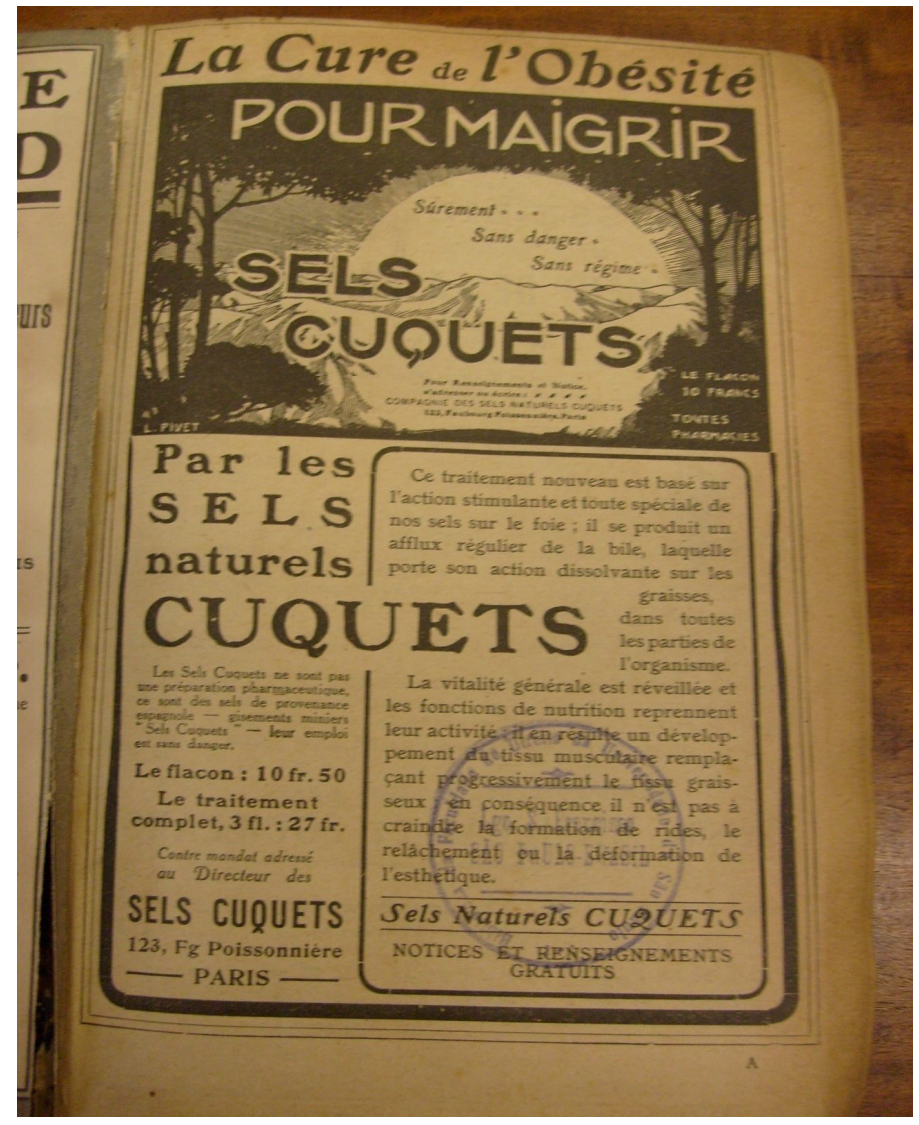

Logo, a utopia de um corpo perfeito é garantida pelo tratamento com os sais naturais no almanaque francês, e pelo Iodhyrine, no brasileiro, ambos não visando apenas à beleza do rosto ou do busto, mas sim o todo, o conjunto que sustenta e reforça a harmonia traduzida pelas temáticas do Bem e do Belo nas cidades poéticas do melhor dos mundos possíveis de almanaque.

É na busca pelo ideal de beleza na modernidade, que se encontram os diferentes produtos e tratamentos de estética nos almanaques, ora visando à perfeição do rosto, ora do corpo como um todo, conquistado por meio da estetização do mundo moderno, a sua transformação em idade de ouro para deleite. Nesse viés, encontra-se o Crème Simon no Almanach Hachette para o ano de 1910, utilizado para clarear, aveludar e amaciar a pele “Pour Blanchir, Velouter, Adoucir". Ainda há recomendações de uso, "En cas de Gerçures, Cuissons, Rougeurs”, para pessoas que apresentam, rachaduras, sensação análoga à queimadura e vermelhidão, na pele. 
Considerando o microcosmo místico-poético aqui analisado, observa-se que a propaganda do creme vai ao encontro da oferta do Belo garantida nas páginas herméticas dos almanaques, o que direciona ao universo do sagrado com todas as suas ritualísticas de culto ao corpo, fazendo da morada dos santos, dos signos, dos astros e dos homens dotados de poderes sobrenaturais em tais livros, a imitação arquetípica da habitação dos deuses olímpicos, cuja Beleza excelente traduz-se simbolicamente pela tez veludosa dos leitores, divinizada em decorrência do uso do cosmético. É, pois, no flanar pelas ruas da polis excelente ao folhear as páginas dos almanaques, que se recobra simbolicamente o in illo tempore, que segundo Eliade, representa o tempo em que os deuses desciam à Terra e se combinavam com os homens, do mesmo modo que os homens podiam subir aos céus com muita facilidade. A autora ainda menciona que esse intercâmbio sagrado é cessado em decorrência do resultado de uma falha ritual, tendo sustado as comunicações entre o céu e a Terra, o que ocasionou a retirada dos deuses para o ponto mais alto dos céus. A partir de tal rompimento, menciona que os homens têm no labor seu alimento e deixam de ser imortais ${ }^{54}$. Tal relação sacra entre homens e deuses é recuperada no microcosmo feérico de almanaque, visto que a formosura infinda dos deuses é retomada pela Paidéia Poética que educa os leitores para a excelência, por meio da imitação dos representantes do divino, tendo na Poiésis de almanaquias, o segredo para alcançar o Sublime. É, pois, tal diálogo sagrado que a epopéia de almanaque às avessas retoma, fazendo com que os leitores sejam os próprios heróis em meio às deidades na modernidade, tendo para suas lutas diárias o antídoto necessário para combatê-las, como se a prisão de Ulisses na Ilha de Ogígia, metamorfoseada de massa caótica moderna, tivesse na poética a sua libertação, recobrando a comunicação com o sagrado pela Paidéia de cada dia, em que santos, astros, signos e áugures, são retirados do ponto mais alto de céu para voltar a ter acesso livre nas ruas da idade de ouro atualizada.

$54 \quad$. Eliade, p. 81. 


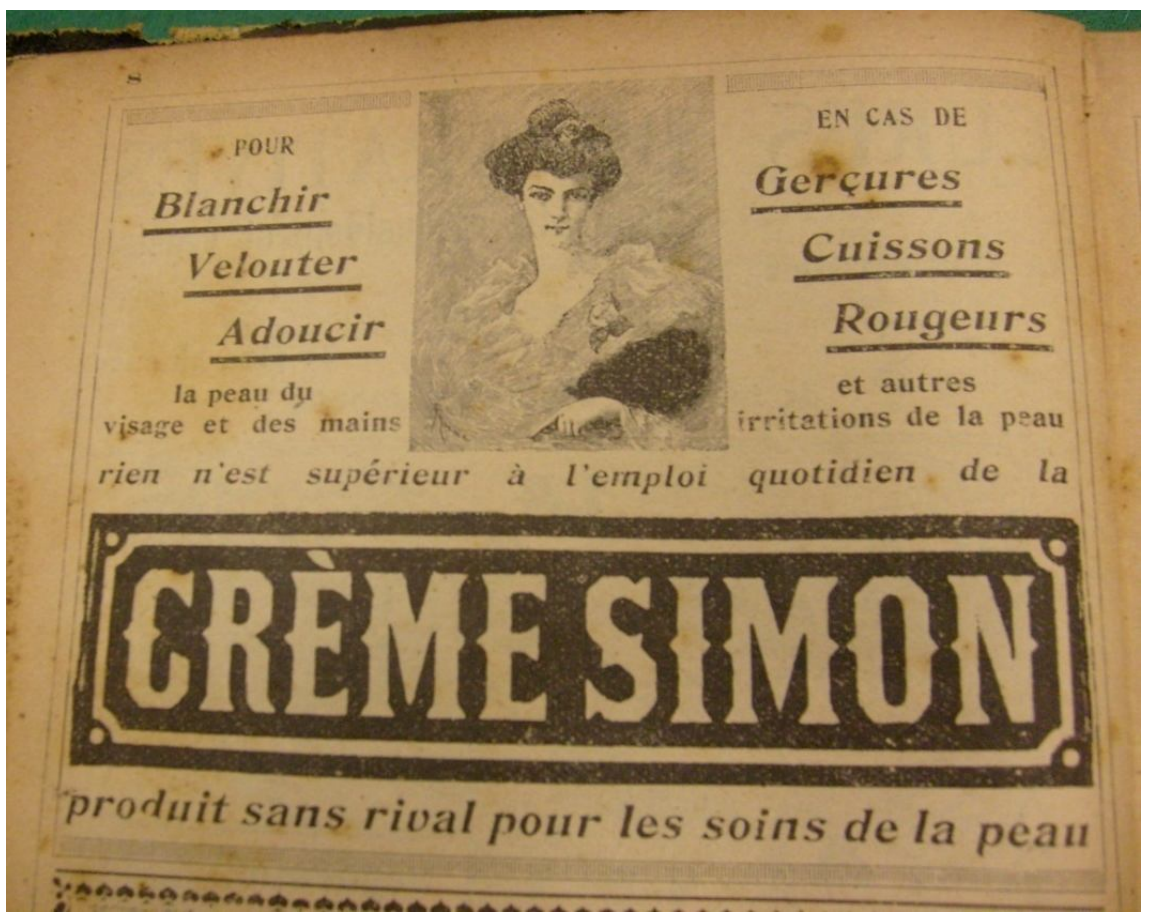

É para a retomada da plenitude perdida que os cuidados com rosto, pelo uso do Creme Simon, são recomendados, para o tratamento das mãos e de outras irritações da pele, consequentemente, de seus traços representativos do escoamento do Tempo Profano. Ainda garante a superioridade perante os outros "rien n'est supérieur à l'emploi quotidien de la Crème Simon produit sans rival pour les soins de la peau”, que certifica os leitores do Almanach Hachette de que não há produto semelhante no mercado da coqueteria, por conseguinte, concorrente à altura.

Logo, a aplicação diária proporciona todos os benefícios mencionados e ainda visa o clareamento da pele, como uma espécie de branqueamento da tez que recupera o viço perdido, tendo nos cuidados estéticos uma simbologia de retenção da inexorabilidade do tempo, ou seja, a garantia de um produto que tem poder tanto para apagar as marcas indicativas do envelhecimento, quanto da prevensão de seu aparecimento, assegurando simbolicamente uma epiderme cuja Beleza é eterna, como a dos deuses. O resgate do frescor e da alvura da tez, livrando a usuária da vermelhidão ou da sensação abrasadora da pele e de outras irritações, faz do Crème Simon o responsável pelo ideal de beleza, uma cútis e mãos perfeitas garantindas pelo alcance do Belo. É, pois, na Paidéia Poética em consonância com a mística de almanaque, que as leitoras têm lições para recuperar a Beleza do in illo tempore, intocável a Cronos, cuja formosura cintilante, - de Apolo traduzida pela cabeleira loura que caía nos ombros em belos cachos, de sua irmã gêmea Ártemis de estatura e beleza incomparáveis e de 
Afrodite, deusa da beleza e dos prazeres, nascida numa concha de pérola e segundo Homero levada por Zéfiro à ilha de Chipre para ser criada pelas Horas ${ }^{55}$, - é a elucidação do Tempo Sagrado como resgate do Belo perdido no Tempo Profano da modernidade.

É o que se nota de forma semelhante no Almanaque Brasileiro Garnier para o ano de 1910, a busca pela excelência por meio de diferentes produtos direcionados aos cuidados da tez, a mesma linha de cosméticos citada no Almanach Hachette, tendo além do Crème Simon outros produtos da mesma marca, como o Poudre Simon e o Savon Simon. São produtos franceses que permitem o acesso ao Belo, além de proporcionar o sonho de participação dos costumes europeus, haja vista que se trata da chamada Belle Époque, em que o uso dos produtos permite simbolicamente o afrancesamento da sociedade carioca.

O Crème Simon também é apresentado como eficaz na eliminação de manchas, mordeduras de insetos, etc, o que permite inferir sobre a utilização do produto no sentido de não haver mal na pele que não seja curado. Do mesmo modo que o almanaque francês, a conservação da cútis no almanaque brasileiro é assegurada, remetendo novamente à temática da eterna juventude sonhada pela humanidade ao longo da história, buscando nos oráculos, nos exercícios gímnicos, nas poções sagradas, nos produtos estéticos, a cura para o Feio e o alcance do Belo.

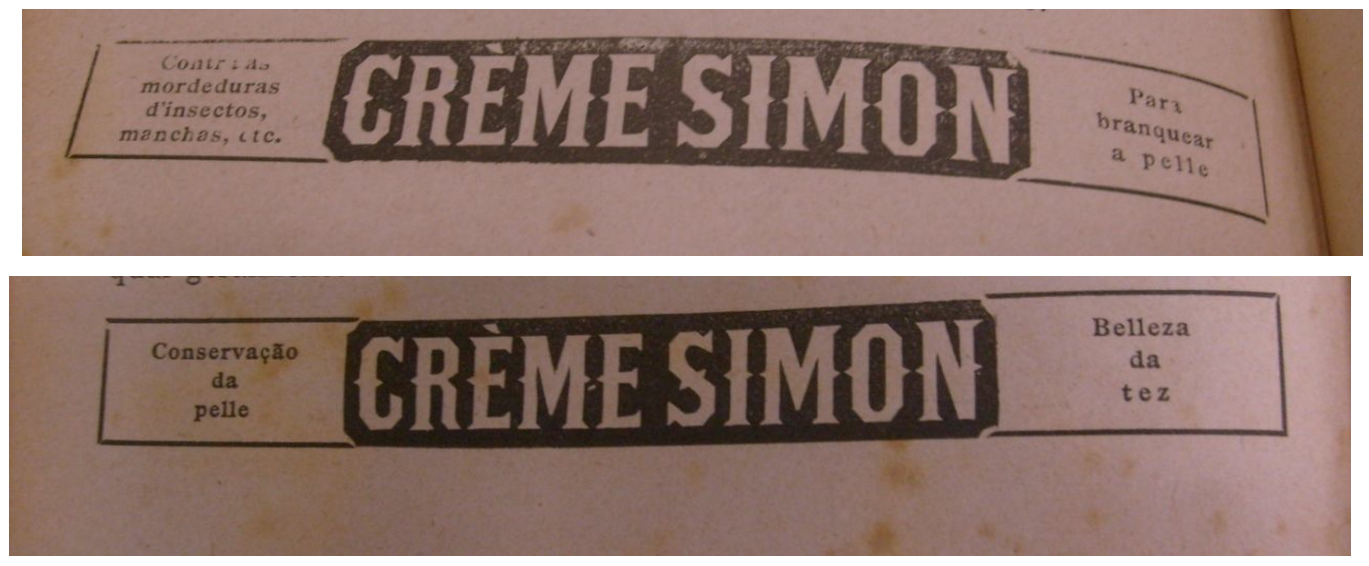

É nessa busca pelo ideal de beleza que se encontram outros produtos da mesma linha, o Poudre Simon, direcionado ainda aos cuidados da pele, garantindo confiabilidade, posto que o "Pó d'arroz" não apresenta o elemento químico bismuto, passando a idéia de um

55. .Commelin, pp. 34 e 60. 
produto natural e verdadeiramente bom para a cútis. Também o cosmético é eficaz na aderência à pele, não provoca uma aparência artificial ao rosto, é invisível e impalpável.

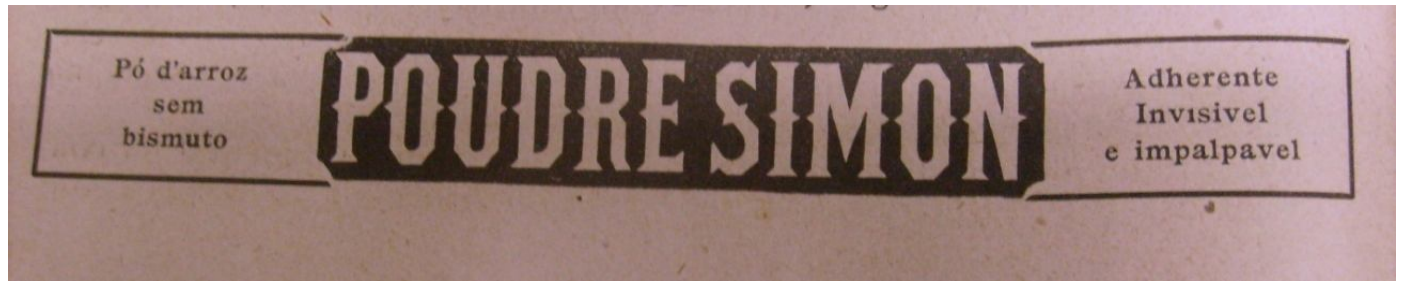

Logo, as leitoras do almanaque brasileiro têm a segurança da qualidade de tais produtos, sem contar o fato de que são franceses, mais um selo de elegância e credibilidade. Tais sonhos de coqueteria são possíveis a todos na cidade da excelência, ainda que inacessíveis para algumas francesas, como menciona Vigarello, as cariocas e parisienses, podem deleitar-se com tais receitas para o Belo, ao flanar pelas ruas de tais polis ideais, tendo na aquisição, ainda que simbólica, ao folhear as páginas dos almanaques, o alcance da Beleza perene:

Evidentemente, as compras não são as mesmas para todos, apesar do sucesso do sistema. Jovem professora, bem no início do século $\mathrm{XX}$, nomeada para um município rural, a "srta O.”, evocada por Jacques Ozouf, diz que da toalete completa só pode se adquirir alguns pequenos frascos de essência de perfumaria'. Ela não menciona creme nem maquiagem, pressionada por um salário logo gasto no aluguel, alimentação, roupas...Jeanne Bouvier, igualmente, operária parisiense no fim do século XIX, subtrai de suas despesas cotidianas centavo por centavo, confessa seu "desconforto", suspeita de que suas amigas fazem sórdidos sacrifícios para "comprar luvas, perfumes e mil objetos de toalete"; dificuldades quase idênticas ainda entre as jovens empregadas do começo do século XX descritas por um dos raros romances a elas consagrado, como "'vestidas com negligência e perfumadas a preço vil'’. (VIGARELLO, 2006, p.137)

Considerando a acessibilidade igualitária no melhor dos mundos possíveis, concernente aos deleites de almanaquias, observa-se que a urbe dos sonhos é edificada sob a égide da equidade, semelhante à polis platônica, onde todos têm acesso às mercadorias que fazem sonhar e trazem verdadeiramente o in illo tempore, o Tempo Sagrado sem males, oposto à distinção entre os entes e à presença de imperfeições, tradução das marcas que denunciam o decurso do tempo, as mazelas sociais da modernidade e uma constante lembrança da proximidade da finitude. O resgate da idade de ouro, por meio dos produtos que produzem o Belo como em um passe de mágica, remete ao que Commelin menciona sobre os Astros - que aqui tem ligação direta com o microcosmo de almanaque com seus diversos calendários e signos - que para os poetas são oriundos do sagrado ou divino e eram objeto de culto peculiar e de adoração característica, sendo invocados pelos mortais em determinadas circunstâncias 
adversas. Ao dirigirem-se a eles, os homens e os heróis o faziam pelo mérito e pelo esplendor de seus nobres atos, o que elucidava tal reverência como o caminho para atingir a imortalidade e o prestígio de uma glória inacabável, ou seja, equiparar-se aos deuses e adentrar na sua morada ${ }^{56}$. Ora, tal busca por imortalidade e glória nos Astros, como passagem para o Divino, direciona à atmosfera mística de almanaquias constituída por uma espécie de abóboda celeste repleta de astros, de signos, de santos e de homens dotados de poderes sobrenaturais, que intermediam a relação com o Sagrado, tendo na abolição da finitude o alcance do Sublime que, por sua vez, inscreve-se simbolicamente na tez divinizada dos leitores pelos produtos cuja composição quimérica produz arquétipos da Beleza dos deuses.

O alcance do Belo é complementado, pela Paidéia Poética, na orientação dos leitores a adquirir, uma sorte de kit de beleza para a excelência, por conseguinte, a busca pelo tão almejado corpo ideal, possível em mais um produto anunciado da mesma linha, o Savon Simon, que hidrata e amacia a epiderme por ser à base de Crème Simon, além de ser "Chimicamente puro", ou seja, garante a inexistência de elementos químicos que possam danificar a pele, seguramente natural. Também certifica os leitores do almanaque brasileiro de que se trata de um sabonete "absolutamente mogeneo", rigorosamente balanceado em sua fórmula e sem misturas duvidosas. Logo, a linha de produtos Simon alimenta a quimera de uma beleza infindável adquirida por meio de seu uso, ainda a construção de um ideário coletivo no qual o Belo é possível, eliminando as imperfeições que porventura possam comprometer o microcosmo perfeito, construído por meio dos jogos de espelhos-sessões dos caleidoscópios de utopias, os almanaques, que refletem formosura jamais vista.

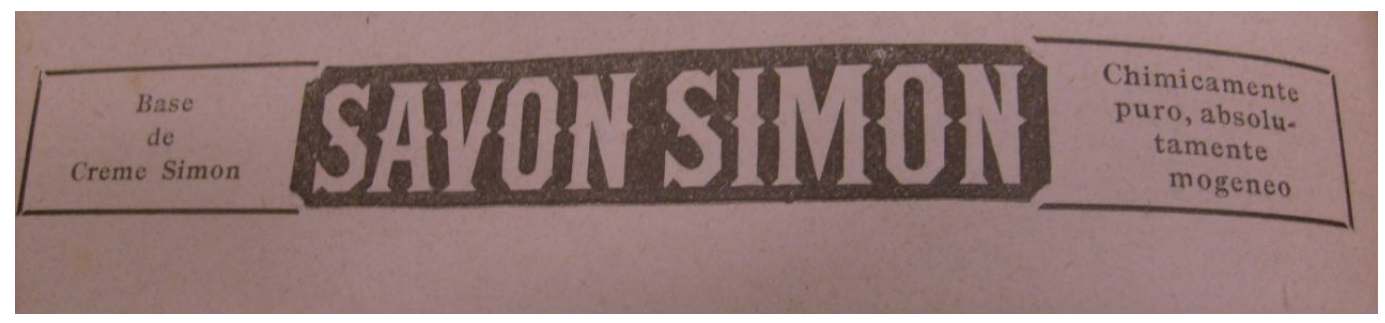

Prosseguindo com o ato de engendramento do corpo ideal, de uma beleza dos deuses em tais livros herméticos, em consonância com a edificação ininterrupta da Terra sem Males, tem-se ainda os diversos tratamentos para os problemas de queda de cabelo, no Almanaque

$56 \quad$. Commelin, p. 91. 
Brasileiro Garnier para o ano de 1914, o Peladum da Loção Berdié - que garante por meio de seu uso "o crescimento certo dos cabellos, da barba, etc" - como parte do tratamento, o Sabão Hygienico, recomendado para assegurar a sua eficácia. Para isso, apresenta a certificação de que tais produtos receberam "Medalha D'Ouro e Grand Prix” em Paris, assegurando sua confiabilidade. Além de sua credibilidade para com os leitores, o anúncio garante que sua aquisição é simples e módica, sendo o tratamento completo no valor de $6 \mathrm{fr}$. 60, havendo apenas uma taxa para os compradores estrangeiros, "o preço da encommenda postal', o que garante aos leitores do almanaque brasileiro um produto importado sem comprometer o orçamento. Adquirindo a loção Berdié e o sabão higiênico, o leitor ainda recebe "Indicações gratuitas para o desapparecimento de pelliculas, queda dos cabelos e seu crescimento", ou seja, há solução até mesmo para reter os efeitos naturais do tempo, como a temível calvície ou a perda total dos cabelos, que denunciam, por conseguinte, o comprometimento da beleza ideal no sítio maravilhoso de almanaque. Ora, nesse microcosmo feérico, o leitor vê-se protegido da passagem inexorável do tempo, pois tal tratamento garante a cessação da queda dos cabelos, além de todos os cuidados que os produtos fornecem ao couro cabeludo e à barba, como a eliminação de "pelliculas', quiçá de possíveis caspas, seborréias, entre outros, assegurando, dessa maneira, o alcance do Belo que não se esvai com o decurso do tempo.

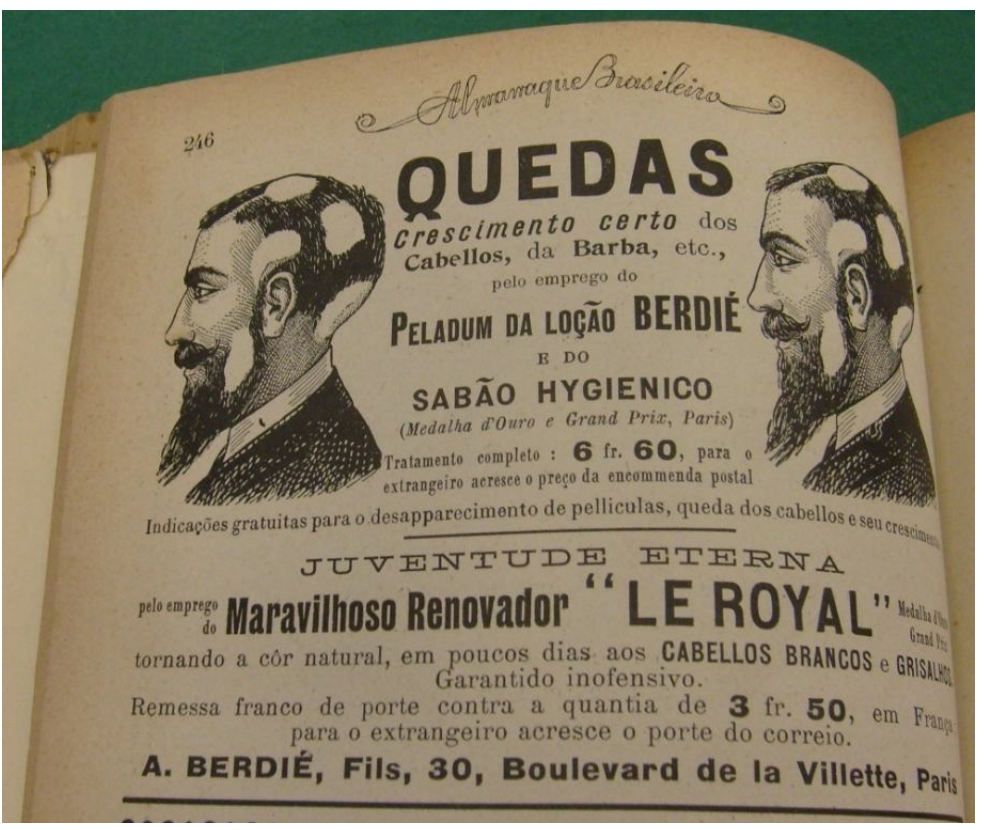


Além da solução para a queda dos cabelos, que visa a manutenção do ideal de beleza dos leitores do Garnier, na urbe perfeita, observa-se ainda o alcance do sonho da Juventude Eterna inscrito no Sublime do microcosmo místico-poético. Para atingir tal aspiração, a Paidéia Poética funciona como facilitadora do acesso ao Le Royal nas páginas do almanaque, tendo na propaganda o discurso quimérico do produto prodigioso responsável pela juventude eterna, o Maravilhoso Renovador. Esse produto excelente é apresentado pelo flâneur-poeta, aedo majoritário da poética de almanaque, - haja vista que os próprios leitores contribuem anualmente com o envio de dicas para a tessitura do melhor dos mundos possíveis, - espécie de veta com faculdades divinatórias capaz de proporcionar solução para todos os males, como a queda dos cabelos, seu branqueamento e até mesmo o envelhecimento decorrente da inexorabilidade do tempo. Tal mensageiro por intermédio dos produtos capilares, produz em seus leitores, a solução para as problemáticas as mais banais, garantindo-lhes a promessa de um corpo perfeito, a salvo das marcas certeiras do tempo. Ora, é simples restituir aquilo que o decurso do tempo levou consigo, com o Le Royal devolve-se "a côr natural, em poucos dias aos Cabellos Brancos e Grisalhos", É importante acrescentar que tais produtos para os cuidados dos cabelos são adquiridos apenas no Boulevard de la Villette em Paris, caso os leitores do almanaque brasileiro queiram lograr a sonhada juventude eterna, têm apenas que dispender de um acréscimo para o porte do correio.

É pelo viés utópico que a atmosfera de poeticidade dos almanaques é construída, fazendo do corpo dos leitores - com uma infinidade de dicas que proporcionam o Belo - um arsenal representativo do meio sócio-cultural onde estão inseridos, tendo a Belle Époque europeia, um papel pacificador, caracterizado por uma extrema joie de vivre, posto que tudo parecia confluir para a construção de um mundo civilizado, o que se observa posteriormente como uma inverdade ${ }^{57}$, também a nossa Bela Época Tropical, com ares pacificatórios e a esperança de novos tempos com o advento da República, que transforma tal período em promessa de civilidade e desenvolvimento. É desses tempos felizes que os ideários eugenistas se alimentam, almejando o aperfeiçoamento da raça e a sua civilização, o que verdadeiramente se dá no microcosmo místico-poético de almanaque, com um ideal de corpo em um mundo de extrema serenidade e equidade, pelo alcance do Sublime em meio aos males da modernidade.

57 . Maurício Silva, A Hélade e o Subúrbio Confrontos Literários na Belle Époque Carioca, São Paulo, Edusp, 2006. 
O comportamento dos leitores do Almanach Hachette também é orientado pela Paidéia Poética, tendo nos anúncios de cuidados com o corpo, a conquista da excelência:

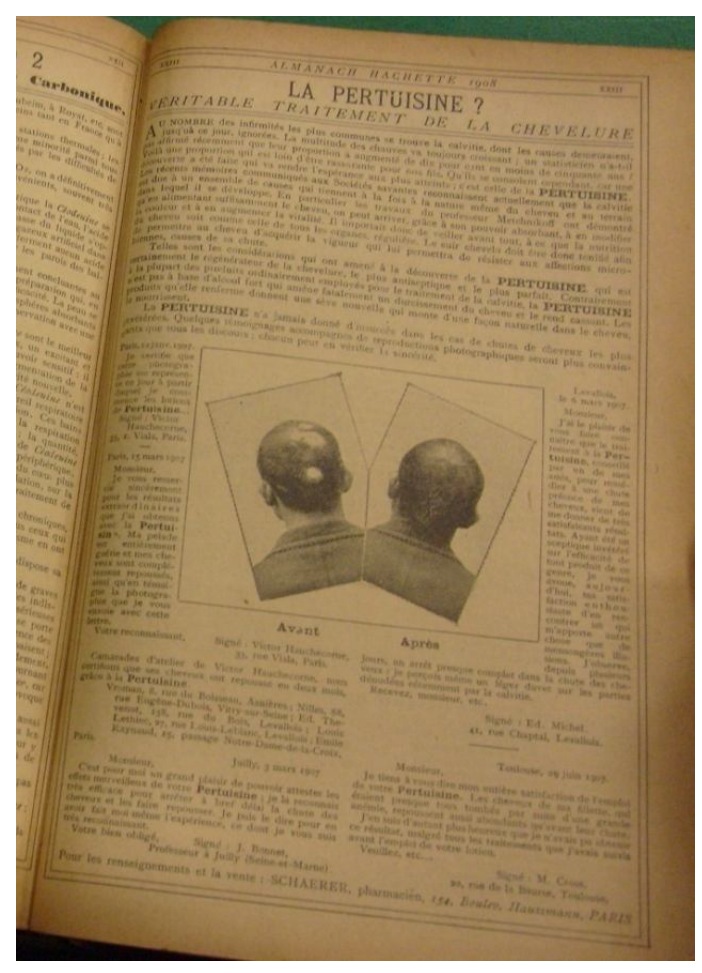

Em meio a cultura de veneração do belo, encontra-se outro exemplo de busca por um corpo ideal, semelhante ao almanaque brasileiro, a eliminação da calvíce por meio do produto La Pertuisine do Almanach Hachette para o ano de 1908. A propaganda garante o verdadeiro tratamento para a cabeleira, iniciando com um breve discurso sobre os problemas de queda de cabelo e informando os seus leitores de que esses aumentaram dez por cento em menos de cinquenta anos. Malgrado tal aumento, o anúncio certifica os leitores de que as próximas gerações não sofrerão com tamanho incoveniente, visto que uma decoberta engenhosa foi realizada, a da Pertuisine. O discurso prossegue com a elucidação de especialistas sobre a origem da cálvice, apresentando um conjunto de fatores, dentre eles, os trabalhos do professor Metchnikoff decisivos por explanar a respeito dos cuidados adequados com o couro cabeludo, como a sua tonificação, que proporciona a eliminação da calvíce, o retorno da cor e da vitalidade.

Ainda, o discurso persuasivo e responsável pelo Belo garante que a Pertuisine é o regenerador mais eficaz da cabeleira e da assepsia (...)"certainement le régénerateur de la chevelure, le plus antiseptique et le plus parfait. Contrairement à la plupart des produits ordinairement employés pour le traitement de la calvitie”. Tal loção tônica que elimina as 
marcas do tempo certifica os leitores de que o produto não contém alcool, o que levaria ao endurecimento do cabelo e à quebra. Desse modo, como no Almanaque Garnier, tem-se a promessa, mesmo que de forma implícita, da juventude eterna, posto que tal produto devolve a cor, a vitalidade e os cabelos perdidos, o que alimenta o ideal de beleza, sem contar a recuperação dos anos que se esvaeceram com o passar do tempo por meio da calvície denunciadora. É para tal esfera simbólica que o leitor de almanaque é cultivado, para o controle quimérico do tempo, pois seu corpo já não está sujeito às marcas do envelhecimento, doravante, no Tempo domesticado pela tessitura da cosmogonia anual, é engendrado e regenerado pelo alcance do Belo, seja no peso, com os medicamentos para emagrecer, seja com os diversos produtos de toalete, ou ainda, com o banimento do que denunciaria no indivíduo a perda do viço, como os cabelos brancos e a sua queda.

É, pois, pela Paidéia Poética que os leitores têm orientação para alcançar o Belo, direcionando ao que Aristóteles na Arte Poética elucida sobre o belo no ser vivente ou em um objeto constituído de partes, o que se dá por meio da ordem de suas partes e pela apresentação de certas dimensões. Tal simetria que produz o belo traduz-se em uma grandeza e harmonia, o que elucida com a imagem de um ser vivente que não pode ser belo se for demasiadamente pequeno (posto que a visão imprecisa decorrente da duração de apenas um momento é quase impercepitível), tampouco se for excessivamente grande (fato que não permitiria ao olhar abranger a totalidade, a unidade e o conjunto escapariam à vista do espectador, como um animal que tivesse um comprimento de dez mil estádios). Nessa perspectiva, complementa a ideia reiterando que se o corpo humano, como o dos animais, para ser considerado belo, necessita de uma certa medição a fim de que seja abarcado com o olhar; igualmente as fábulas devem apresentar uma extensão apropriada para que possam ser facilmente assimiladas ${ }^{58}$. Tal simetria já mencionada pelo desenvolvimento da integralidade humana é conquistada na polis harmônica, visto que se a busca pelo Belo não é alcançada na vida real dos leitores, pode ser atingida no microcosmo quimérico de almanaque, não na fábula de extensão adequada, mas na metáfora epopeica com suas receitas de beleza, de virtude e de equidade para a formação de cidadãos condizentes com a cidade excelente, inscrita no Sublime que liberta das problemáticas do Tempo Profano. Tal libertação permite a conquista do in illo tempore ou da plenitude que não se esvai com o tempo, o que é observado no anúncio da Pertuisine, posto

58 . Aristóteles. Arte Retórica e Arte Poética, trad. de Antônio Pinto de Carvalho. Rio de Janeiro: Ediouro, 15 edição, p.250. 
que os leitores podem usufruir de uma "fórmula" capaz de corrigir as marcas do tempo, como a calvície e os cabelos brancos, proporcionando simbolicamente o sonho da juventude eterna.

O culto ao Belo simboliza as sociedades em questão, a parisiense e a carioca, a busca interminável pelo combate ao Feio que traz consigo a finitude, tendo no envelhecer o rompimento com o ideário de perfeição, pois na leitura dos depoimentos dos leitores que fizeram uso do regenerador capilar, tem-se a impressão de que se trata de um produto confiável e verdadeiramente eficaz no combate a tais males decorrentes da passagem do tempo. Logo, vê-se no anúncio a fotografia do antes e depois de um usuário de Paris ao utilizar as loções Pertuisine, com a cabeleira completamente recuperada, também outros depoimentos de parisienses, de pessoas da província e ainda a declaração de uma mãe cuja filha havia perdido boa parte dos cabelos por conta de uma forte anemia.

$\mathrm{O}$ anseio pelo corpo ideal funciona como espelho ou mimesis da sociedade nos almanaques, carregado de usos e costumes adquiridos nos modelos pré-estabelecidos, sendo construído por meio das relações que os leitores tecem com os outros leitores, bem como pela educação empírica ou sistemática que obtêm ao longo de sua formação enquanto indivíduo de um grupo. É o que Breton afirma de forma semelhante ao colocar o corpo como base identitária do homem, o lugar e o tempo onde o mundo toma forma por meio de um rosto singular. Também esse é o lugar onde o ator abraça o mundo e dele se apropria construindo um universo familiar e comprensível, carregado de sentido e de valores, compartilhável enquanto experiência por todo ator, inserido como ele, nesse mesmo sistema de referências culturais. Através de sua corporeidade, o homem faz do mundo a medida de sua experiência. Ele a transforma em tecido familiar e coerente, disponível à sua ação e permeável a sua compreensão. Emissor e receptor, o corpo produz continuamente sentido, ele insere assim o homem no interior de um espaço social e cultural estabelecido ${ }^{59}$.

É nessa perspectiva que o ideal de corpo ofertado nos almanaques inscreve-se, mimesis refletora carregada de sentidos e de valores, fruto de um mesmo sistema de referências culturais, adquiridos por meio de trocas entre os leitores que, por sua vez, são concebidos por meio de um conjundo de regras e valores comportamentais, cujos males, constitutivos da modernidade ou do Tempo Profano, são suprimidos pelo acesso à excelência dos entes no microcosmo quimérico que produz a verdadeira Beleza do mundo.

59 . David Le Breton, Anthropologie du corps et modernité (Paris: Quadrige, 2008), p. 17 - 18. 
A beleza infindável dos deuses, adquirida no mercado de coqueteria travestido de sonhos de almanaquias, direciona para mais uma análise de oferta quimérica do Belo em tais livros populares, por meio da Paidéia Poética que orienta os leitores sobre o sítio da excelência, o Instituto De Belleza Para Tez do Almanaque Brasileiro Garnier para o ano de 1910.

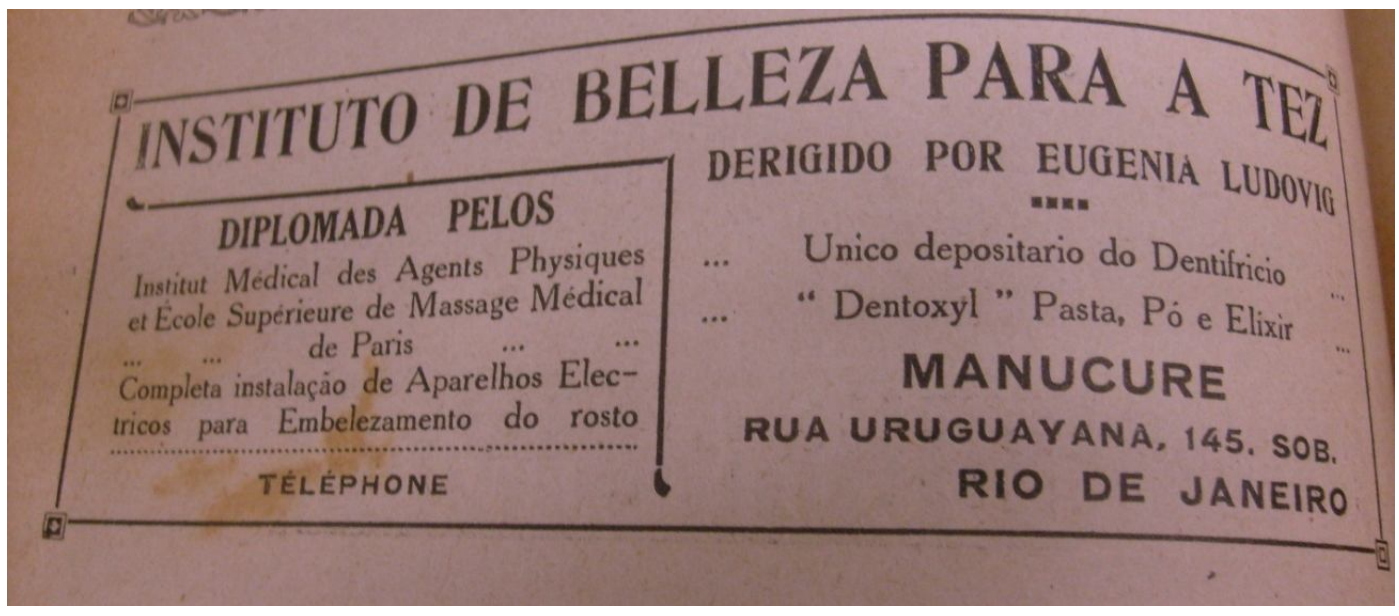

Tal estabelecimento mercador do Belo é dirigido por Eugenia Ludovig, diplomada pelos Institut Medical des Agents Physiques et École Supérieure de Massage Médical de Paris, o que lhe dá prestígio e reforça os ideais franceses seguidos pela sociedade carioca na chamada Belle Époque. Ora, a relação Brasil-França faz-se notável, posto que a qualificação da dirigente Eugenia Ludovig é fornecida aos leitores em francês, que poderia ser traduzida para o português, como sinônimo de requinte em tal período, além de novamente nutrir o diálogo quimérico entre os dois países ou entre as cidades ideais, Rio de Janeiro e Paris, do melhor dos mundos possíveis, com temáticas comuns que possibilitam a caminhada pelas mesmas ruas feéricas repletas de almanaquias deleitáveis. O Instituto de Beleza nos moldes franceses é um lugar onde o sonho do corpo ideal faz-se realidade, baseando-se, no início do século, nos salões concebidos para oferecer "consultas" e realizar "tratamentos", corrigir as imperfeições do corpo e do rosto. O estabelecimento brasileiro inspira-se, pois, nos institutos de beleza franceses, a Société Athéna, na Rua de Abbeville, ainda no anúncio citado, o Institut Médical des Agents Phyisiques, na Rua Blanche, no Institut Scientifique de la Beauté, na rua La Bruyère, dentre outros, como sítios onde a feitura do Belo faz-se de maneira eminente. São esses os arquétipos seguidos, espaços luxuosos em sua maioria, com horários de atendimento e de aplicação de cuidados com o corpo, que reúnem os recursos técnicos os mais 
diversificados e modernos para a época, como o citado na propaganda - a "Completa instalação de Aparelhos Electricos para Embelezamento do rosto"- como menciona Vigarello no Institut des Moyens Physiques, que se utiliza da eletricidade sob todas as suas formas (raios brancos e coloridos). Essa busca coletiva pela perfeição direciona para o mercado que nasce com tal ânsia pelo ideal de beleza, com diversas marcas e seus diversos produtos, técnicas para cuidados com o rosto e com o corpo, além da profissionalização que se faz necessária em tal meio, a da esteticista, cuja função é bem definida nos institutos. É nesses que surgem ofícios os mais especializados, como o de manicure que, por sua vez, é oferecido pelo anúncio do almanaque (manucure) ${ }^{60}$.

Tais institutos de propagação do culto ao Belo representam a preocupação coletiva de busca da eliminação das imperfeições, mais do que um prazer individual, observa-se uma "necessidade coletiva" diante de tais tratamentos de estética, como menciona Vigarello, posto que o Feio não condiz com a tez ideal angariada, remetendo ao microcosmo de almanaque em consonância com a sua misticidade, sendo a própria cidade semiotizada, com seus anseios e signos de logradouros que vendem a beleza dos deuses, representando a eterna juventude e, consequentemente, a conquista da imortalidade, a volta a uma nova Criação. A nova realidade não se dá a partir do limo, mas de cirurgias, de práticas inovadoras e de produtos simbolicamente sacralizados que permitem o alcance da excelência. Ora, a atmosfera sacropoética dos almanaques e a volta ao in illo tempore levam à comparação simbólica entre tais institutos produtores de beleza, com suas diversas práticas de cuidados com o corpo, com o Belo platônico, ou seja, a conquista da excelência tanto da alma, quanto do espírito. Tal busca incessante pela beleza do corpo em tais institutos traduz o próprio conceito de Belo que ultrapassa o mundo sensível, cujas imperfeições corrigidas em tais mercados de divinização, garantem, em consonância com o microcosmo místico-poético de almanaque, a conquista do Belo em si. É, pois, partindo da beleza do corpo em tais estabelecimentos intermediários do Bem, que se considera o Banquete de Platão, tendo na elucidação de Diotima sobre a ação amorosa, das mútiplas formas do desejo universal do que é bom, o amor, a própria parição no belo. Diante disso, prossegue com a proposição de que o amor não é propriamente do que é belo, mas da feitura no que é belo, tendo em tal geração, considerando o mundo como palco das duas forças que movem a humanidade, o nascer e o morrer, a conquista da imortalidade

60 Georges Vigarello. História da beleza; tradução Léo Schlafman (Rio de Janeiro: Ediouro, 2006), p. 139-140. 
angariada como bem que todos anseiam. Concomitante à geração física, que a cada indivíduo exige dedicação, cuja imortalidade é assegurada, tem-se a geração espiritual que melhor protege da sorte desse mundo em constante mudança, que se dá por meio da produção de discursos, com os quais se educam as novas gerações, correspondendo tanto à poesia de Homero ou de Hesíodo, quanto às leis de um Licurgo ou de um Sólon. A explanação sobre o amor cotinua apresentando a dupla geração corporal e espiritual como algo subordinado à extensão que ele é capaz de conquistar nessa ação geratriz, asseguradora da imortalidade. Diante de tal ação geradora, com o intuito de possuir o que é belo e bom ad infinitum, mudase o tom da elucidação, passando à simbologia religiosa da sacerdotisa, que se utiliza de uma linguagem concernente às iniciações nos mistérios, concluindo seu elogio com altivez a respeito do processo integral da criação amorosa, que respeita uma espécie de ascese por degraus, partindo do amor de um só belo corpo, para atingir aos poucos o amor do belo em si, a plenitude alcançada por meio da superação de acidentes que, por sua vez, não devem ofuscar a beleza absoluta ${ }^{61}$.

Considerando a ascese platônica como conquista da beleza absoluta, observa-se que a busca pelo corpo ideal inscreve-se simbolicamente, haja vista o viés místico-poético dos almanaques, em uma caminhada paulatina sobre os degraus que levam ao Sublime, partindo da geração do belo corpo nos institutos e por meio de tantos outros produtos anunciados, passando pelos cuidados com o espírito oriundos das representações do divino e da tessitura dos diferentes discursos, para finalmente adentrar no Absoluto que salva os leitores da efemeridade de todas as coisas. Ora, a geração no belo, pela Paidéia Poética de almanaque, asseguradora da imortalidade, segue o mesmo princípio gradativo de alcance do belo em si, posto que com as lições de almanaquias os leitores têm uma espécie de manual onírico a seguir para conquistar a verdadeira Beleza do mundo.

A conquista do Belo por meio do embelezamento do corpo, como uma sorte de égide sobre a qual se desenvolvem as virtudes dos leitores, a fim de alcançar a beleza absoluta, é também apresentada no Almanach Hachette para o ano de 1910, tendo nos Produits De Beauté com efeito Miraculosa, os meios para galgar os degraus que levam à plenitude.

Esse poder milagroso, assegurado pelos produtos, representa simbolicamente os ideais compartilhados pela sociedade parisiense, mas garantidos unicamente nas páginas dos almanaques ou no melhor dos mundos possíveis, posto que o efeito prodigioso apreendido

61 . Platão. O banquete, ou, do amor. Rio de Janeiro: Difel, 2008, p. 50. 
pelo vocábulo "miraculosa" promete a perfeição buscada por grupos sociais que almejam a obtenção de uma beleza utópica imune às marcas certeiras do decurso do tempo.

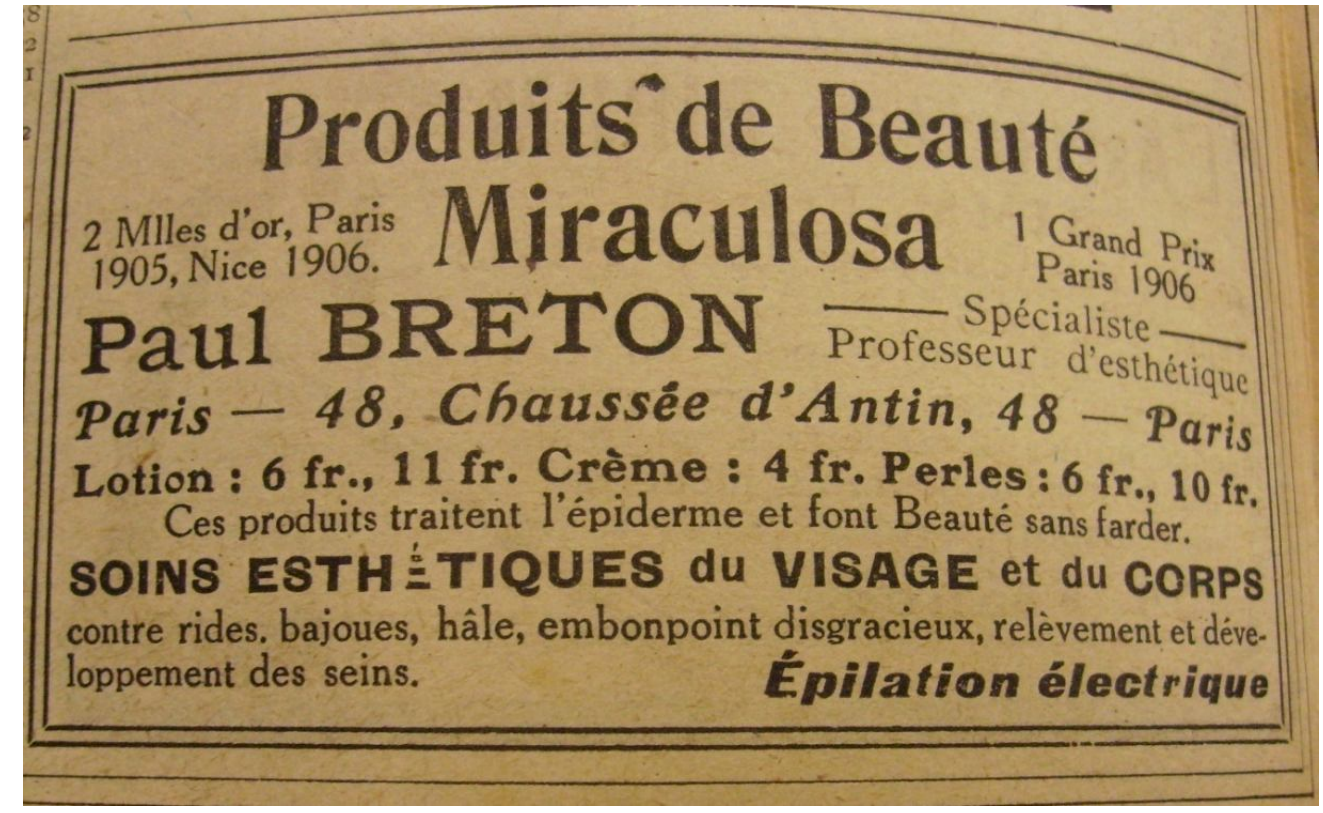

Nesse viés, tais produtos corrigem as imperfeições que garantem o ideal de corpo e de rosto, contribuindo para a formação de habitantes belos e, por conseguinte, virtuosos, na Paris da excelência, eliminando qualquer traço que denuncie a precariedade da condição humana. Assim, a eficácia dos produtos é garantida por duas medalhas de ouro, "2 Mlles d'or", em Paris no ano de 1905 e em Nice no ano de 1906, além do Grand Prix em Paris também no ano de 1906. Ainda é necessário ressaltar o fato de tais produtos terem confiabilidade por se tratar de um Spécialiste e Professeur d'esthétique, Paul Breton, que se apresenta como seu responsável. Esses, além disso, garantem o tratamento da tez e a aquisição do belo sem extenuar: "Ces produits traitent l'épiderme et font Beauté sans farder", proporcionando cuidados estéticos, para o corpo e para o rosto, contra toda sorte de sinais decorrentes da passagem inexorável do tempo ou puramente para a preservação da beleza: rugas, bochechas caídas e flácidas, bronzeamento, desenvolvimento do busto, levantamento e aumento dos seios. Como parte dos cuidados estéticos, o anúncio também apresenta a Épilation électrique, como um recurso de ponta, explicitando o progresso da estética, que se vê banalizado, criando um verdadeiro universo da coqueteria que se utiliza de todas as técnicas de seu tempo. Tal progresso mostra um mercado com mudanças nos primeiros anos do século XX, agrupando os cosméticos em uma expressão inédita: "produtos de beleza". Assim, "com a mesma marca e 
seguindo essa nova caracterização, temos diferentes produtos, cremes, maquiagens, águas de toalete, sabonetes, dentifrícios, pós diversos, em torno de um mesmo artigo" "62, como a lotion, o crème e a perles Miraculosa. Logo, o mercado de cuidados de beleza, situado ao logradouro Chaussée d'Antin, número 48, responde aos anseios da sociedade parisiense que se vê extremamente preocupada com a beleza, alcançada, verdadeiramente, de forma ideal, no sítio maravilhoso de almanaque. Tal geração do belo proporcionada pelos produtos não é perene, visto que as reparações, que asseguram a eliminação das imperfeições e das fealdades, não permitem o alcance do belo em si que permanece para sempre, o que ocorre somente no microcosmo místico-poético de almanaquias. É, pois, a criação do belo, por intermédio de tais produtos, carregado de misticidade, que remete novamente ao Banquete de Platão, tendo na elucidação dos deuses como inteiramente bons e belos, a personificação alegórica das essências constantes e absolutas de uma porção transcendente do universo, enquanto que os mortais caracterizam a parte inferior, sítio onde os belos seres são representativos da presença efêmera do belo em si que, por sua vez, jamais se concretiza neles. É, pois, na contemplação final para além da sobreposição socrática, do próprio belo em si, manancial de belos discursos, único apto a suprir a carência inerente ao Amor, cujo impulso, ainda que inicie por meio de um belo corpo, logra transpor os níveis dos poemas homéricos ou das leis de Licurgo. Essa vagarosa e sistemática elevação constitui um avanço no que concerne ao domínio da precariedade dos entes desse mundo e o alcance da constância vital de um mundo superior ${ }^{63}$.

Semelhante ao almanaque brasileiro, os produtos Miraculosa ou o logradouro intermediário do Bem, cujo professor de estética, Paul Breton, uma espécie de demiurgo tecedor do belo, garantem a representação da beleza efêmera como parte do belo em si que, por sua vez, tem a sua completude na ascese poética que perpassa todos os degraus de almanaquias até chegar ao Sublime nas cidades excelentes do melhor dos mundos possíveis. Ora, é na contemplação final do próprio belo em si, - as urbes harmônicas, repletas de belos discursos que nutrem o espírito, tendo do mundo superior seus representantes divinos, - que se dá a elevação impulsionada por meio de um belo corpo, o dos leitores, o domínio paulatino, pela Paidéia Poética, da precariedade humana na ascese que os salvam da perenidade e, por conseguinte, dos males da modernidade.

Como parte constitutiva do culto ao Belo, tem-se o papel da Paidéia Poética a partir da simbologia das normas sociais nos almanaques, sendo o corpo representante dos códigos da

62 . G. Vigarello, op cit., p.139.

63. O Banquete, p. 54 . 
sociedade, possuindo um sistema de significação inserido na cultura. Dessa forma, a arte de utilizar o corpo segundo Mauss está ligada à educação, que se sobrepõe ao simples fato de imitar, o que chama de técnica uma prática tradicional eficaz, não fazendo distinção de um ato mágico, religioso ou simbólico. Nessa perspectiva, reforça que o mesmo deve ser tradicional e eficaz, pois afirma que não há técnica e nem transmissão se não há tradição. É o que nos diferencia dos animais, a transmissão das técnicas muito provavelmente pela oralidade ${ }^{64}$.

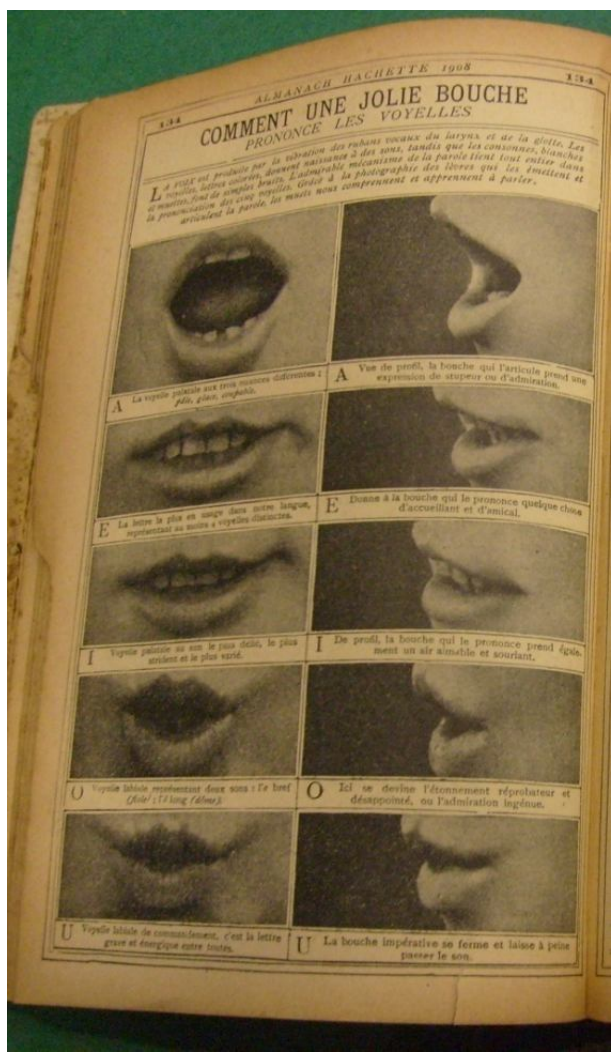

É o que se observa no Almanach Hachette para o ano de 1908, posto que os treinos para adquirir uma bela dicção ao pronunciar as vogais fornecem modelos didáticos a ser seguidos, seja para ter prestígio no meio em que vive, seja para simplesmente fazer parte de algum grupo social específico ou puramente como apreensão das técnicas passadas de geração a geração. A partir de tal lição de comportamento, observa-se que a pedagogia do belo novamente faz-se presente, posto que a tarefa passada, pela Paidéia Poética, aos leitores e inserida no microcosmo de excelência, traduz o ideal de Homem alcançado apenas em tais livros herméticos, belo no corpóreo e no modo de agir. Dessa forma, têm-se exercícios, - ou

64. Marcel Mauss. Sociologie et Anthropologie. (Paris: Presses Universitaires de France, 1950), p.371. 
aulas de etiqueta a preço módico, por conseguinte, acessível a todas as classes, - para alcançar a destreza da pronúncia perfeita, por meio primeiramente de uma súmula informativa sobre o caminho percorrido pela voz até ser emitida, com a vibração das cordas vocais da laringe e da glote. Também ressalta as vogais e letras que dão vida aos sons, enquanto que as consoantes brancas e mudas originam simples barulhos. Assim, o leitor apreende que o admirável mecanismo da fala dá-se inteiramente pela pronúncia de maneira adequada das cinco vogais. Para tanto, a Paidéia Poética assegura com o auxílio da fotografia, grâce à la photografie des lèvres, como em uma aula que se utiliza da imagem para melhor explanação, com lábios que emitem e articulam as palavras, a sua eficácia, que até mesmo os mudos compreendem e aprendem a falar utilizando-se do método.

O caminho prodigioso para a aquisição de uma pronúncia ideal condizente com os cidadãos da cidade excelente, consequentemente, de uma boca admirável, está em seguir os dez passos didáticos da fotografia, sendo o órgão correspondente, representante do corpo que é moldado para o Belo, que segundo Rodrigues é, um portador da marca da vida social, expressando a preocupação coletiva em gravar nele, fisicamente, determinadas transformações que são escolhidas a partir de um repertório cujos limites se encontram no domínio virtual, os quais não podem ser determinados. $\mathrm{O}$ autor ainda chama a atenção para o fato de que o corpo passa por diversas modelações, representando dessa forma, uma massa de modelagem, cujas formas são elegidas de acordo com as intenções da sociedade, que simbolizam a fisionomia do seu próprio espírito ${ }^{65}$. Ora, é pela Paidéia Poética que os leitores do Hachette têm a possibilidade de se aproximar do ideal corpóreo sonhado pela humanidade desde a Antiguidade, mas alcançado apenas no microcosmo quimérico de almanaque, seguindo a pedagogia do belo com as lições de repetição das vogais, à maneira da fotografia, partindo da criação de um só belo corpo para atingir o belo em si, por meio da Poiésis que permite o alcance do Sublime, pela modelação ininterrupta a cada edição de almanaque.

Sendo assim, a repetição das regras de pronúncia faz parte de todo um processo de cultivo para a beleza, ou seja, a Paidéia Poética que educa os leitores do almanaque para um comportamento de excelência é a mesma que os conduz, pelo viés místico-poético, para o Absoluto. Tal percurso preparatório para o belo em si consiste nos seguintes degraus a serem ultrapassados, no primeiro passo, temos a vogal palatal A, em suas três diferentes nuanças

65 . José Carlos Rodrigues. O tabu do corpo. (Rio de Janeiro: Dois Pontos), p. 62. 
pâle, glace, coupable. No quadro ao lado, observa-se que a mesma vogal aparece pronunciada por meio de uma boca de perfil que a articula dotada de expessão de stupeur ou admiration, elucidando um tom de refinamento que tal repetição pode proporcionar. Logo abaixo, vê-se a letra $\mathrm{E}$, a mais usada na língua francesa, representando ao menos quatro vogais distintas, que segue na imagem ao lado, como aquela que permite à boca que a pronuncia algo do tipo acolhedor e amigável. Ainda destaca-se a vogal palatal I, considerada a mais solta, estridente e variada, que de perfil, ao lado com a imagem da boca que a pronuncia, passa um ar amável e sorridente. Logo abaixo, tem-se a vogal labial O, representando dois sons, o breve (fiole) e o longo (dôme), ao lado a imagem de perfil, em que se percebe o espanto reprovador e desapontado, ou a admiração inocente. Tem-se ainda a última imagem, o U labial de ordem, é a letra grave e enérgica entre todas, a qual de perfil ao lado, mostra-se como a boca imperativa que se fecha e deixa apenas passar o som.

Diante disso, vê-se que o leitor do almanaque tem receitas para educar seu corpo para o excelente, no caso a busca pelo ideal de pronúncia das vogais, por meio da apropriação do código social, a repetição da mesma articulação por todos, sendo a Paidéia Poética responsável por tais aquisições sociais na ministração, sem distinção, aos diversos grupos que compõem a sociedade. Nessa apropriação das regras de um comportamento ideal, como pronunciar de maneira adequada as vogais, tem-se todo um jogo simbólico, posto que a partir da boa articulação, o falar corretamente, traduz o pertencimento a grupos seletos da sociedade, mas que no microcosmo onírico de almanaque, representa a equidade na geração da égide sobre a qual o Belo e o Bom serão alcançados na contemplação final, por meio da Poiésis que abre os olhos dos leitores para a Verdade.

Semelhante à Paidéia Poética de formação para o ideal de comportamento/pronúncia, como preparação do corpo para a ascese do belo em si, têm-se os Productos Hygienicos do Doutor E. H. Neppo, com os quais o leitor, do Almanaque Brasileiro Garnier para o ano de 1914, recebe lições para combater a obesidade, os pelos indesejados e cuidar da pele, modelando a base corpórea na beleza para então estar apto a percorrer o caminho que o leva ao Sublime. Ora, a educação para a excelência dá-se por meio de modelos para a manutenção do corpo limpo e saudável, tendo a obesidade como algo prejudicial tanto à saúde, quanto à estética da perfeição de entes sãos e belos condizentes com a cidade ideal. Para tanto, como parte do culto ao belo, uma espécie de preparação simbólica do corpo e do espírito para a ascensão ao mundo superior que, por sua vez, increve-se no viés místico-poético de almanaque, o produto Anti-obesidade "Neppo" produz resultados significativos, com a - 
"Preparação única empregando-se em fricções ou massagens sobre as partes demasiado gordas. - Supprime os excessos locaes: Gordura do pescoço, gordura das costas, excesso d'ancas, etc. O seu emprego regular conserva a naturalidade das formas". Logo, utilizando o produto e seguindo a pedagogia para o belo, garante-se a beleza eliminando as imperfeições, posto que o tratamento regular não compromete as formas naturais do corpo, sendo capaz de corrigir os excessos sem desfigurar o bem mais precioso, a aparência majestosa, sinônimo de aptidão para habitar a urbe excelente. Diante disso, é importante salientar que o Brasil entra no século XX com a modernização instaurada, sendo palco da imitação dos hábitos civilizados parisienses, característica da chamada Belle Époque carioca, corroborando o estudo comparativo aqui desenvolvido, tendo na representação notadamente francesa do anúncio a ponte que intercambeia almanaquias que edificam a trajetória para a aquisição do belo em si nas urbes da excelência, Paris e Rio de Jeneiro. Ora, é da Rue de Miromesnil, número 98, que surge simbolicamente a chave que abre a porta que leva ao Sublime, tendo no alindamento do corpo a linha de partida da maratona da beleza a percorrer pelos leitores brasileiros e parisienses, a fim de atingir, pela condução da Poiésis, a chegada ao Bem e ao Belo nas polis excelentes.

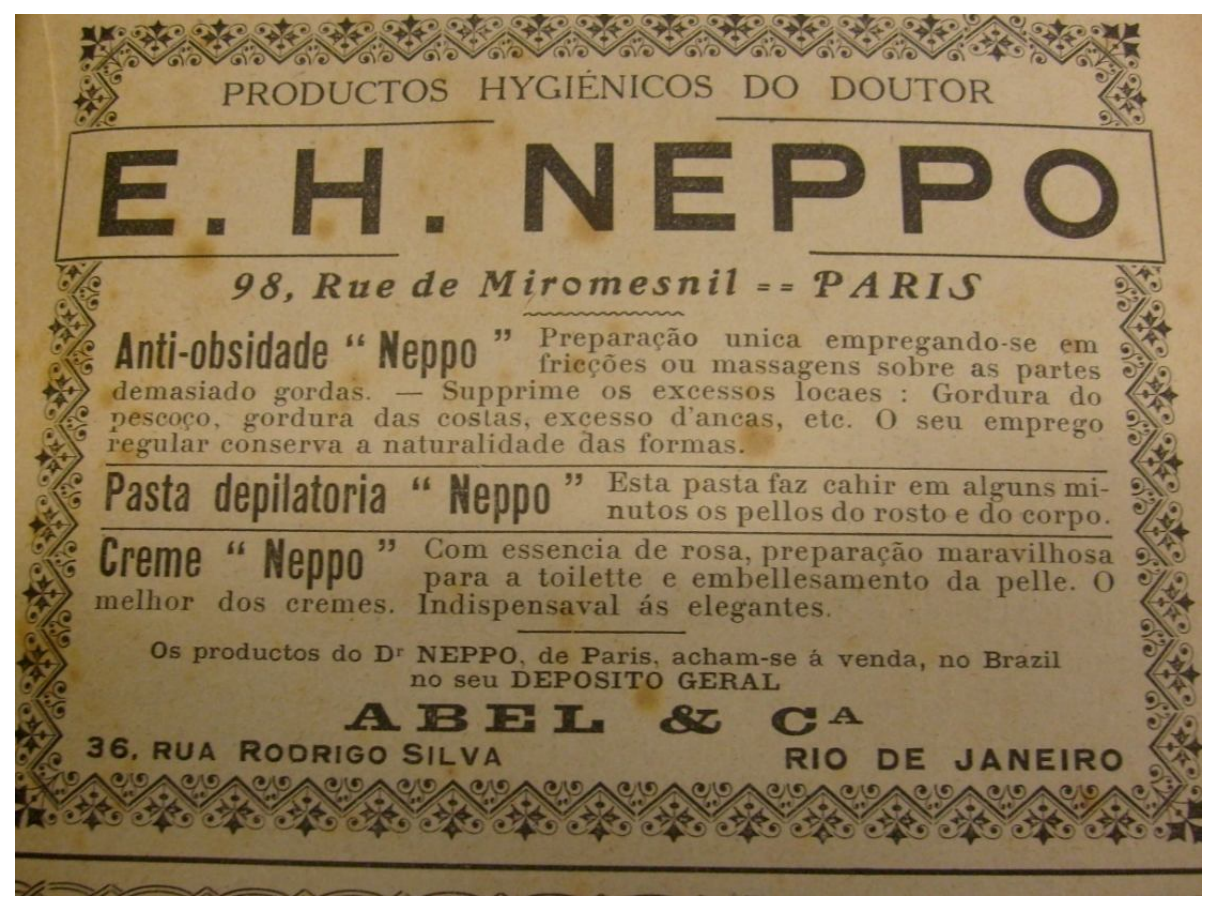

É, pois, calcado nas idéias de eliminação das fealdades para edificação do belo, que caminham os produtos do Dr. Neppo, visto que tanto a Pasta Depilatoria, quanto o Creme 
são caracterizados como produtos higiênicos, o que remete ao nome dado à parte da Medicina da Antiguidade, como já mencionado, higiene, que prezava pelos cuidados do médico para com os sãos, tendo na figura do doutor Neppo a função de desenvolver nos leitores brasileiros e franceses, as virtudes do corpo, em consonância com as da alma, haja vista a Arete platônica e a Paidéia Poética de almanaque que buscam o cultivo da integralidade humana. Desse modo, a busca pelo corpo perfeito caminha junto ao sonho da construção da cidade ideal, visando, dessa forma, criar indivíduos sadios, civilizados e participantes de uma verdadeira utopia, o ideal do corpo que leva ao da urbe excelente que, por sua vez, conduz à Terra sem Males de almanaque, caracterização do belo em si.

A oferta da beleza corpórea da propaganda visa o aperfeiçoamento dos entes para uma cidade perfeita, com um corpo saudável e as virtudes adquiridas, a fim de poderem contemplar a luz que emana do sol sem nebulosidades, mas diretamente alimentar-se de seus raios que abrem seus olhos, por intermédio da Poiésis, para a Plenitude. Ora, o anúncio do Almanaque para o ano de 1914 tem em seu último produto Creme Neppo a sustentação de tal ideário, pois esse "Com essência de rosa, preparação maravilhosa para a toillete e embellesamento da pelle. O melhor dos cremes. Indispensavel ás elegantes.”, derrama simbolicamente o bálsamo floral que tem poder para aromatizar a alma e o corpo com o Belo. Logo, o embelecer a pele por meio da preparação fantástica remete ao tom de prodígio utilizado no discurso, alimentando uma espécie de efeito miraculoso, dado o vocábulo "maravilhoso", conduzindo os leitores ao encontro do belo ou das virtudes alcançadas, como preparação para o belo em si no microcosmo excelente. Tal feitura do belo por meio da manipulação excelente do doutor Neppo, direciona à temática da eterna juventude do deus Amor citada no Banquete de Platão, cuja elucidação de Agatão aponta tal divindade como a mais bela e melhor dentre as outras, a mais jovem em decorrência de sua perspicaz fuga da velhice, assaz veloz, e ainda o fato de nos perseguir ininterrupitamente. Prossegue ressaltando que o Amor odeia a natureza da decrepitude e dela não se achega nem de longe, estando sempre no convívio dos jovens, seguindo a máxima de que o semelhante sempre do semelhante se aproxima ${ }^{66}$. É justamente o remédio contra o envelhecimento que atemoriza o Homem desde a Antiguidade e, por conseguinte, o combate às fealdades, a beleza divina, que o almanaque oferta por meio dos produtos do doutor Neppo, para então, em seu microcosmo místico-poético dar-se o alcance do belo em si, aquele que não perece com o decurso do tempo.

66

. O Banquete, p.130. 
É, pois, através da geração do corpo belo nos almanaques, que tal microcosmo onírico faz com que os leitores participem da utopia da imortalidade, dando viço à parte que envelhece por meio de um outro ser, o ente belo oriundo da eficácia dos produtos e métodos prodigiosos, a fim de que, aptos na beleza da alma e do corpo, concluam o processo de alcance do belo em si, que não se esvai com o tempo, mas que é constante e divino. É dessa forma que o corpo belo ascende ao mundo superior, ao Sublime da idade de ouro atualizada, livrando-se das amarras da modernidade que o impede de dar o salto libertador, o conhecimento do Bem e do Belo inscritos na poética de almanaque do melhor dos mundos possíveis. 


\section{Elixires para uma longa vida: bálsamos para todos os males}

Como parte da edificação das cidades ideais, construídas a partir das diversas telas dos almanaques Hachette e Brasileiro Garnier, observa-se a existência de inúmeros elixires, medicamentos e informações de teor medicinal, que corroboram a atmosfera quimérica de tais livros populares, promovendo a terapêutica e a cura para todos os males da modernidade, resguardando, pela Paidéia Poética tecedora do Sublime, os leitores das enfermidades que os circundam no melhor dos mundos possíveis.

Nota-se que os diversos medicamentos e orientações que aparecem nos almanaques colaboram na tessitura de um Cosmo livre das moléstias existentes no mundo, edificado por meio de um prognosticador-doutor - o flâneur-poeta - capaz de orientar todos os outros que se apresentam por meio de seus laboratórios e da prestação de seus serviços médicos. Sendo assim, a atmosfera construída em tais livros é sustentada por uma crença coletiva, a dos leitores que acreditam na eficácia, muitas vezes, miraculosa, de tais medicamentos e orientações:

A eficácia da magia na cura de distúrbios psicossomáticos se funda na sua capacidade de atribuir significados às desordens fisiológicas.O mito que o xamã ou o feiticeiro produz torna coerentes as dores e sintomas. $\mathrm{O}$ doente, tendo compreendido o sentido daqueles sinais, fica bom.O mito lhe dá, pois uma linguagem a partir da qual estados de dor, ansiedade, confusão possam ser formulados.(MONTERO, p.63,1986)

É importante salientar, que malgrado o teor científico de tais medicamentos e orientações, é mister ressaltar a linguagem simbólica que apresentam em consonância com o microcosmo místico-poético de almanaque, ora pelos dias dos santos, ora pela astrologia e seus signos, ainda pelos diversos áugures que receitam verdadeiras fórmulas de boa ventura, uma espécie de Paidéia médico-poética que cura os leitores das moléstias e problemáticas da vida. É, pois, nas cidades ideais que os leitores atingem a sanidade perene, tendo no mercado terapêutico de almanaquias, as prescrições para combate das doenças do corpo e para os desassossegos da alma, cuja manipulação da panacéia poética, curativa dos males que assolam a modernidade, sara a ignorância que impede a contemplação do Sublime.

É pela Paidéia Poética que os leitores são curados e educados para a aquisição das virtudes necessárias, a fim de habitar nas cidades da excelência, posto que ao terem orientações terapêuticas concernentes às mazelas do corpo, têm, concomitantemente, lições para curar os males do espírito, cujo desenvolvimento da integralidade abre caminho para o alcance da Plenitude. A Paidéia médico-poética inscrita na misticidade de almanaque, cuja terapêutica está diretamente ligada ao universo do sagrado, remonta à época em que as 
doenças tinham relações diretas com manifestações de magia, bruxaria e feitiçaria, estando ligadas ao mundo sobrenatural, tendo sua cura em rituais e poções que eliminavam qualquer moléstia de origem espiritual. É justamente nesse microcosmo místico-poético que o sagrado mistura-se ao profano, na relação entre o mundo superior e seus representantes divinos nas páginas de almanaque, os emissários inspiradores das práticas curativas, que prescrevem os elixires e as orientações médicas fortalecidas pela leitura astrológica, pela proteção des seus diversos santos, de homens dotados de poderes sobrenaturais, dentre outros.

A Paidéia Poética busca, então, pelas lições terapêuticas para cuidados do corpo e do espírito, a fundamentação na medicina da Antiguidade, que tinha no liame, a formação de Homens virtuosos e sãos, para habitarem nas polis harmônicas, suas práticas embasadas, direcionando a um texto elucidativo de tal busca no Almanaque Brasileiro Garnier para o ano de 1906, A Medicina na Antiguidade, fazendo do rememorar o caminho para atingir a gênese sem males.

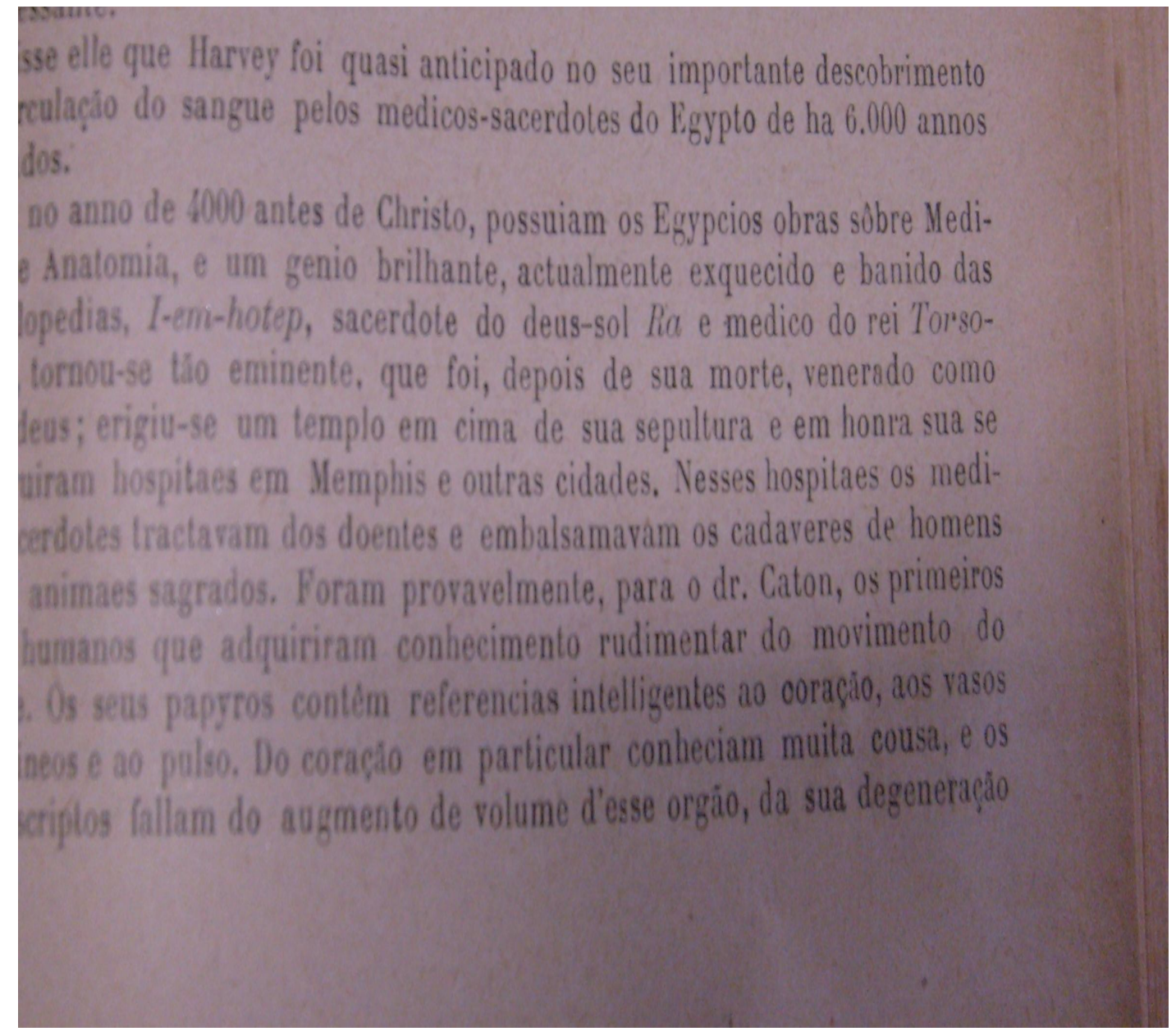


Ora, o discurso mnemônico sobre as origens da Medicina do Doutor Ricardo Caton, em Londres, no Royal College of Physicians, é caracterizado como uma narrativa deveras interessante, elucidativa da descoberta da circulação sanguínea por Harvey ter sido antecedida pelos médicos-sacerdotes do Egito há mais de seis mil anos. Prossegue mencionando que já no ano 4000 antes de Cristo, os egípicios possuíam obras de Medicina e de Anatomia, tendo na figura insigne, olvidada no período em questão e suprimida das enciclopédias, I-em-hotep, sacerdote do deus $R a$ e médico do rei Torsothros, a consagração de sua relevância ao venerálo como semi-deus após sua morte. Tal importância é notória por terem erigido sobre sua sepultura um templo, e ainda, como meio de exaltar suas virtudes, foram construídos hospitais em Memphis e outras cidades, onde os médicos-sacerdotes embalsamavam os corpos de homens e animais sagrados. Logo, o retorno aos egípicios permite ao doutor Caton encontrar os primeiros saberes rudimentares, em tais entes, a respeito do movimento do sangue, cujos papiros apresentavam proposições sábias sobre o coração, os vasos sanguíneos e o pulso. Conheciam, em particular, muito a respeito do coração, tendo em seus escritos informações concernentes ao aumento de volume de tal órgão, da sua degeneração gordurosa, de sua movimentação, batimentos e derramamento pericárdico. Acrescenta informações sobre tais insignes e antiquíssimos investigadores no que tange ao exame do aumento do volume do coração e da rarefação respiratória oriundos da estagnação e da não-circulação adequada do

sangue. Diante do exposto, o discurso ainda salienta que o berço da Medicina racional e da Anatomia, não foi a Grécia, mas sim o Egito, sendo tais descobertas constatadas bem antes de Hipócrates e Galeno. Logo, as considerações dos gregos sobre a circulação sanguínea eram praticamente as mesmas proferidas pelos egípicios há muitos séculos antes. $\mathrm{O}$ doutor Caton prossegue seu discurso novamente enaltecendo tais médicos-sacerdotes olvidados do Nilo, com a menção sobre o tratamento proveniente de há quatro mil anos, ao menos, para a moléstia valvular incipiente do coração. Tal terapêutica consistia em dar o máximo de repouso ao coração, o que para a sociedade de sua época, segundo o doutor inglês, devia ser praticado em demasia. Finaliza a narrativa assaz interessante, com a referência à ilustre figura 
de I-em-hotep, médico, arquiteto, astrônomo e alquimista, tão prestigioso, que após sua morte foi sepultado como filho do sumo deus Ptah.

É, pois, com tal discurso recordativo, que a Paidéia Poética tece o caminho para atingir a idade de ouro, o in illo tempore de deleites, cujo passado gerador da prática medicinal permite a abertura para a recuperação do tempo em que a cura dava-se por meio da mistura do sagrado ao universo do profano, o que faz da figura do médico-sacerdote a representação da terapêutica mística prescrita, pelo flâneur-poeta e seus auxiliares, na Medicina quimérica de almanaque. Ora, o ato de rememorar descobertas de duas civilizações antigas, cujos saberes são inscritos na figura dos médicos-sacerdotes dotados de conhecimento, fazendo desses intermediários do divino ou até mesmo divinizados após sua morte, a elucidação do Tempo Sagrado recobrado pela volta à gênese do fazer medicinal, tendo na ciência mesclada à ritualística, a salvação para as enfermidades do corpo e do espírito na modernidade. É justamente tal medicina carregada de misticidade de que o doutor inglês serve-se em seu discurso, como uma espécie de memória apaziguadora decorrente da impotência diante dos males da modernidade, que a Paidéia Poética absorve - inscrita no microcosmo feérico de almanaquias - para salvar seus leitores das enfermidades físicas e espirituais que os atingem, abrindo caminho para o alcance do Sublime no melhor dos mundos possíveis.

É na antecipação da descoberta da circulação sanguínea pelos egípicios, tirando tal patende das mãos do doutor Herry, que a Paidéia Poética vale-se do recobrar o berço médicosagrado dos antigos, para orientar os leitores imersos em um Tempo de Velocidade, com lições de máximo repouso ao coração, ou seja, uma pedagogia simbólica da desaceleração e da desintoxicação que abre passagem para a formação de cidadãos sãos e nobres condizentes com as cidades excelentes, e resguardados das desventuras do mundo moderno que encobrem o Divino.

É na oferta de bálsamos para todos os males que os leitores obtêm a cura simbólica, apenas com a leitura dos almanaques para alcance do Sublime, sem mesmo adquirir tais medicamentos - mas pela alimentação diária poético-mística de almanaquias - considerados como verdadeiros remédios para as intempéries cotidianas, o que alimenta a utopia de um mundo perfeito tanto para aquele que toma, quanto para aquele que se nutre da crença em seus efeitos mágicos oriundos de seu microcosmo hermético.

Tais panacéias colaboradoras da tessitura do Sublime são a própria mimesis do papel das mercadorias comercializadas no mundo circundante, o da Velocidade exacerbada, como produtos que são comprados em um catálogo, produzidos em série, mas embebidos de 
poeticidade todos os anos pela estetização da realidade, a cada nova edição dos almanaques. Nesse processo, os medicamentos feéricos transformam o lucro da mais-valia moderna, de seus laboratórios ou de seus produtores, em receitas para sonhar, tendo tais livros populares o papel de verdadeiros guias médicos a preço módico, - como o Médecin Charitable publicado na França entre 1600 e 1700, e reeditado em 1757 com o título Médecine des pauvres, e outros numerosos tratados de medicina, segundo Bollème, reservados a pessoas modestas, dentre eles, o Apothicaire charitable, o Opérateur des pauvres, que forneciam receitas econômicas para tratar enfermidades, cujas prescrições baratas substituíam o próprio médico, além de rezas e de orações com tal finalidade ${ }^{67}$ - para aquisição da arete dos habitantes das polis harmônicas por meio de receitas que curam os males do corpo e da alma, e elevam à Plenitude. É nesse viés, ao mesmo tempo, de cunho milagroso, com seus diversos medicamentos e tratamentos imersos em um microcosmo mágico e religioso, que se observa a questão da produção/consumo nos almanaques, sendo práticas denunciadoras no Almanaque Brasileiro Garnier e no Almanach Hachette da produção capitalista, que impedem o Homem de alcançar o Ideal e de enxergar o Belo.

É, pois, Giovanni quem analisa essa questão da produção/consumo dos remédios no Brasil, o que também leva ao mesmo processo em relação aos medicamentos na França, visto que esses também fazem parte das relações produção/consumo no modo de produção capitalista, o que constitui e mantém a "ideologia do consumo",68. Assim, além do valor sagrado-poético existente em tais elixires, medicamentos e tratamentos, proporcionando a equidade concernente à aquisição da cura por todos e para todos os males, tem-se uma espécie de ação delatora da impotência da medicina mercadológica moderna representativa da produção/consumo nas propagandas de almanaquias, o que direciona para a leitura de tais medicamentos como espelho malsim do engendrar capitalista. Logo, tais anúncios informados, pela Paidéia Poética denunciadora do Caos moderno, apresentam verdadeiras receitas, no microcosmo quimérico, para mazelas de qualquer ordem, desde um antídoto para sanar problemas de timidez, passando pela promessa de longevidade e sanidade perene, até chegar à cura da ignorância para abertura ao Sublime.

67 . Geneviève Bollème. La Bibliothèque Bleue. Paris: Julliard, 1971, p.35.

68 .Geraldo Giovanni. A Questão dos Remédios no Brasil. (São Paulo: Editora Polis, 1980), p. 40. 
Diante disso, é importante mencionar o que Pignarre $^{69}$ fala sobre o mercado diferenciado dos remédios que, por sua vez, não apresenta as mesmas características do mercado capitalista em geral, tendo os economistas da saúde apontado diferenças significativas entre eles. O que o autor destaca como diferentes sistemas de prescrição e reembolso de um país para outro, mas todos têm a característica de não permitir a constituição de verdadeiros mercados livres. Existe uma espécie de consenso em todos os países sobre a necessidade de fazer, ao menos parcialmente, livrar a economia da saúde dos mecanismos reguladores do mercado (da oferta e da demanda), porque esses produziriam muitas ilegalidades, consideradas inconciliáveis com o direito à saúde. Mas ele chama a atenção para o fato da economia da saúde, atualmente, estar fragilizada em todos os países devido às transformações da economia mundial, como se ela tivesse problema de inserção enquanto constituinte para funcionar segundo suas próprias normas. É justamente essa realidade hodierna ou moderna, ao considerar os medicamentos de almanaque datados das primeiras décadas do século XX, que a Paidéia Poética aclara, fazendo da Poiésis a salvação para os males que tais medicamentos não têm poder para sanar, tendo na terapêutica místico-poética, para o corpo e para o espírito, a educação para Sublime.

É nesse viés que se analisa o prodigioso medicamento que promete solução até mesmo para a timidez, a Cefalosa, no Almanaque Brasileiro Garnier para o Ano de 1914, que vem acompanhado de garantia para o desenvolvimento da inteligência e da memória, além de inspirar atrevimento e êxito aos usuários. Nesse processo de cura para as problemáticas humanas, tem-se ainda toda uma simbologia implícita, pois os temores que acompanham o homem desde os primórdios, são vencidos eficazmente com o medicamento, que também funciona como um facilitador para a fala, destruindo o receio e a dubiedade, fazendo com que as palavras cheguem abundantes e justas nas alocuções, proporcionando réplicas, rápidas e bem-sucedidas.

69 . Philippe Pignarre. Qu'est-ce qu'um médicament? Um objet étrange, entre science, marche et société (Paris: La Découverte, 1997), p. 119 - 120. 


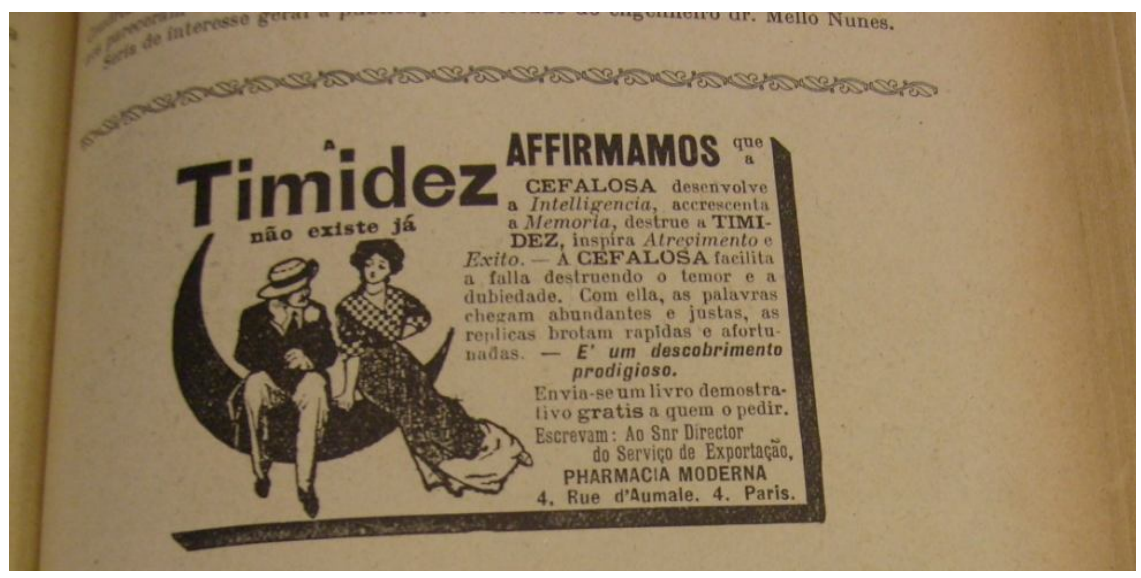

Em virtude de tais efeitos, observa-se que se trata de Um descobrimento prodigioso, o que é reforçado pela imagem que acompanha o anúncio, pois o casal de enamorados sentados na lua confirma que a Timidez não existe já, ou seja, que tal medicamento proporciona o rompimento de possíveis problemas amorosos decorrentes de falta de iniciativa, possibilitando a conquista certeira, sob o luar, da amada. É pois, nesse universo místico-poético dos almanaques, que se observam soluções para obstâncias as mais variadas, como o homem que é representado na imagem de forma um tanto quanto inferiorizada em relação à mulher, cabisbaixo e com uma das mãos no queixo, como se não conseguisse aproximar-se dela que, por sua vez, mostra-se autêntica e segura de si.

Logo, nota-se que o medicamento vai além de suas funções terapêuticas, pois tem poder de proporcionar conquistas amorosas, de acordo com a simbologia presente na imagem e na enunciação do texto, além de estar em consonância com o universo um tanto quanto místico dos almanaques, o que remete ao que já os gregos denominavam como filtros amorosos, que segundo Carneiro ${ }^{70}$ na Europa, durante a Idade Média, aquelas que faziam uso de tais poções eram consideradas como feiticeiras, cujo desígnio era a busca pelo amor, pela imortalidade e pela ressureição. Também o autor relata que os filtros de amor, além de fins eróticos e afrodisíacos, eram utilizados em todos os âmbitos da medicina feminina, o que lê-se de forma semelhante no sítio maravilhoso de almanaquias, pois aquele que proporciona simbolicamente a possibilidade da conquista amorosa e da imortalidade é o flâneur-poeta, tanto com a Cefalosa, quanto com os tantos outros elixires, o poeta-áugure que constrói um microcosmo a salvo de todas as problemáticas humanas na República das delícias carioca. Assim, o medicamento-filtro tem poder de elevar o casal literalmente à lua, o que

70 .Henrique Carneiro. Filtros, Mezinhas e Triacas. (São Paulo:Editora Xamã, 1994), p. 31. 
representaria o rompimento da barreira no ato de amar produzido pela timidez do pacienteenamorado.

Todos os efeitos poético-curativos que tal medicamento simbolicamente apresenta podem ser adquiridos pelo livro demonstrativo enviado gratuitamente, como guia deleitoso da Pharmacia Moderna, situada à Rue d'Aumale, número 4, em Paris, sendo adquirido por meio do contato com o Senhor Diretor dos Serviços de Exportação, o que novamente elucida o intercâmbio místico-poético entre as cidades excelentes, Paris e Rio de Janeiro, que prescrevem receitas para sarar os males do corpo e do espírito dos leitores, a fim de preparálos para adentrarem na idade de ouro de almanaque. Dessa forma, o livro serve como demonstrativo para comprovação dos resultados do primoroso medicamento, além de estimular sua compra, assegurando que não se trata de engodo, fornecendo-o como garantia de eficácia. Ora, o que se tem, no Almanaque Brasileiro Garnier, é a construção de toda uma estratégia de revelação do Caos moderno para geração de uma nova Criação, por meio da poética regeneradora que se dá na consideração da Cefalosa como um produto que se soma as tantas outras mercadorias do mundo moderno, desde biscoitos a medicamentos, transformados, em tal microcosmo quimérico, em almanaquias para deleite. Nesse sentido, o descobrimento prodigioso denuncia o que já mencionado acima com Giovanni sobre a expressão "ideologia de consumo", tomada no almanaque como atitude denunciante de um conjunto de elementos que representa uma determinada "concepção de mundo", como as representações, os valores, as pautas de conduta, etc, que orientam as práticas de consumo, cuja execução produz a realização do valor gerado na produção capitalista. $\mathrm{O}$ autor ainda menciona que essa expressão está diretamente ligada a outras categorias ideológicas, como o individualismo, a cidadania, o status e a mobilidade social, as quais operam no sentido de “esmaecer” as contradições próprias à estrutura de classes ${ }^{71}$. É, pois, a Paidéia Poética que salva os leitores de tal cenário utilitarista, tendo na Poiésis o medicamento pujante para salvar o Homem dos enganos da modernidade e levá-lo ao encontro do Sublime, posto que mitigar as discrepâncias entre as classes já não é necessário, haja vista a igualdade, em todos os âmbitos da vida, entre os habitantes do melhos dos mundos possíveis.

É nesse sentido que se observa o papel do flâneur-poeta nos almanaques, ora prognosticador, com suas ofertas de controle do destino, ora mercador, proporcionando acesso

71

. Giovanni, op. cit., p. 40 
a mercadorias que delatam a "ideologia de consumo", saciando as veleidades dos leitores pela poética de almanaque que abre seus olhos para a verdadeira Beleza do mundo. É mister elucidar que se o autor aborda a questão dos remédios no Brasil, sua produção e consumo, é importante destacar que nos almanaques a expressão "ideologia de consumo" se aplica às primeiras décadas do século XX, em que Giovanni (1980, p.50) destaca, "De um modo geral, todos os processos industriais utilizados no setor estavam limitados à manipulação de substâncias naturais, de origem animal ou vegetal, preparados em pequenos laboratórios, ou mesmo em farmácias ou boticas”, cuja seriedade não era questionada pelos usuários. Apesar de não se tratar do contexto hodierno de produção capitalista e da manipulação ser realizada a partir de substância naturais, o que vai ao encontro de práticas mantidas e prescritas, a partir da medicina caseira, no almanaque, já no início do século, com o desenvolvimento industrial, pode-se observar o embrião da cultura capitalista, posto que os leitores, representam, grosso modo, o mundo de consumo burguês circundante, denunciado pela Paidéia Poética como muro que os separa do conhecimento da Verdade, mas regenerado, pela mimesis edificadora do melhor dos mundos possíveis.

A atmosfera utópica dos almanaques ou das polis harmônicas, imune tanto às enfermidades quanto ao decurso do tempo, é explicitada ainda no anúncio do Elixir AntiFlegmatic do Dr. Guillé, que assegura Uma Vida Longa e Agradável, no Almanaque Brasileiro Garnier para o ano de 1914. Tal oferta de vida longeva e ditosa simboliza a própria essência dos elixires na história, que prometiam a imortalidade, além de serem considerados uma panaceia universal procurada pelos alquimistas, com poder para curar todas as moléstias e prolongar a vida de forma interminável. É nessa perspectiva simbólica que se analisa o Elixir Anti-Flegmatic, em consonância com o microcosmo místico-poético de almanaque, oferecido pelo poeta-áugure como antídoto capaz de combater doenças causadas pelos fleumas ou excesso de biles. O elixir, então, é usado para combater as enfermidades causadas, como menciona o anúncio, pelo: “Clima, hygiene, privações, excessos de trabalho ou de nutrição". 


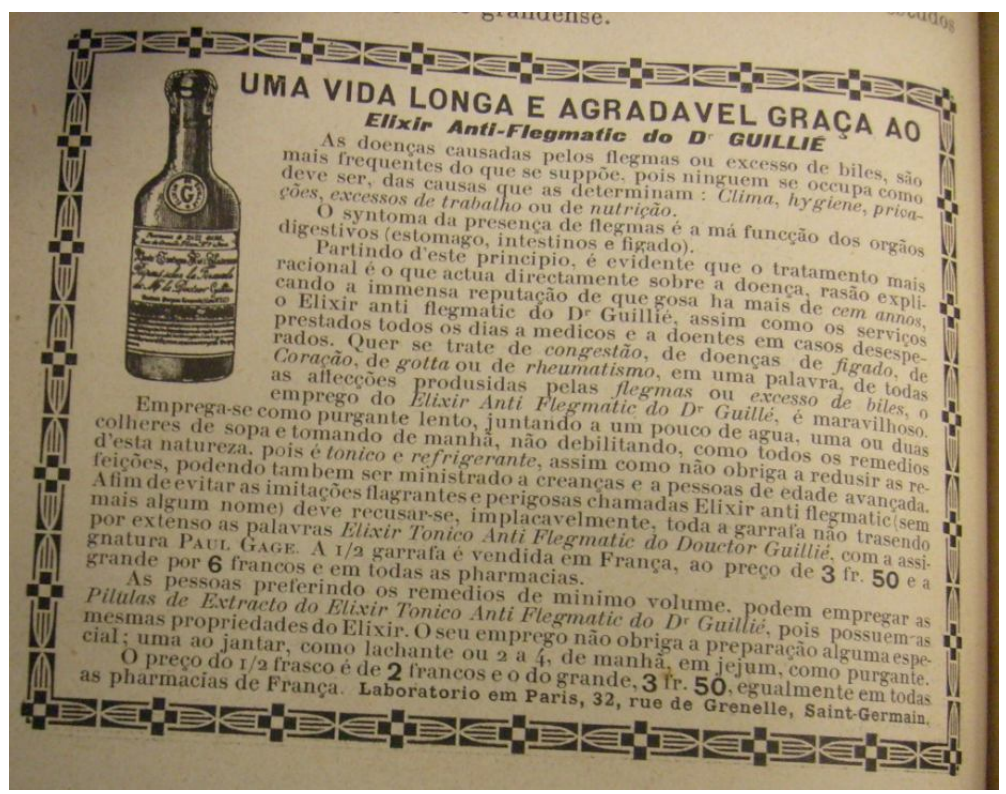

O discurso certifica os leitores de que o sintoma da presença de fleumas no organismo é o mal funcionamento dos órgãos digestivos, como o estômago, os intestinos e o fígado. Tal afirmação direciona ao vocábulo fleuma, que segundo Aurélio (2000, p.300), significa S. f. 1 . Um dos quatro humores corporais, segundo a teoria hipocrática e a galênica (ver galenismo). 2. Fig. Frieza de ânimo; serenidade, impassibilidade. 3. Fig. Falta de interesse, diligência ou pressa; lentidão, pachorra. Considerando tal definição, infere-se que o elixir representa simbolicamente a solução para toda falta de ânimo e de iniciativa nos leitores do Garnier, além de incidir diretamente na biles, um dos quatro humores corporais. Diante disso, é importante discorrer sobre a teoria dos quatro humores que Carneiro aponta como o sangue, a fleugma, a bilis negra e a bilis amarela, correspondentes aos temperamentos sanguíneos, fleugmáticos, coléricos e melancólicos e aos quatro elementos da natureza, o fogo, a terra, a água e o ar, além de relacionar às quatro qualidades de secura/umidade e temperatura. $\mathrm{O}$ autor também menciona a questão do sistema galênico, inspirado em Empédocles, ter sido materializado numa terapia fundamentada no conceito de cura como limpeza catártica, cujas sangrias eram a principal técnica ${ }^{72}$. É, pois, na própria elucidação da busca pela Medicina da Antiguidade do texto analisado no início do capítulo, que novamente se evidencia que a tessitura das polis ideais - haja vista que se trata de um medicamento francês ofertado no mercado quimérico de almanaquias brasileiras - dá-se no resgate das origens do fazer

\footnotetext{
72 . Carneiro, op. cit., p.74.
} 
medicinal, com Empédocles e Galeno, meio para alcançar, pela Poiésis, a cura embebida de miticidade, advinda de tal período, que leva ao Sublime da Terra sem Males.

A cura pelo ato de rememorar o antigo permite a menção ao sagrado sustentador de tal medicina, tendo na figura do médico-sacerdote mesclado aos temperamentos sanguíneos e a limpeza catártica, sob o patronado dos deuses, a representação mística do fazer medicinal nos almanaques, cuja terapêutica dá-se semelhantemente pela proteção diária dos santos, signos e astros, bem como nos oráculos proferidos por homens dotados de poderes sobrenaturais. É, pois, no tempo recuperado, o sagrado em detrimento do profano moderno, que as cidades excelentes são edificadas, direcionando ainda à polis harmônica de Platão, cuja alusão a Asclépio, deus da Medicina e da cura, sustenta o viés místico-poético tecedor do Sublime. Tal menção considera a realidade da profissão médica de então, voltada para os homens sãos que padeciam de algum mal momentâneo, como reflexo do Estado Ideal, visto que a polis excelente tem seus cidadãos formados na mais alta arete. É justamente por isso que o diálogo aponta uma importância secundária para com a figura do médico, ainda que exalte o saber do deus Asclépio, responsável pela geração da arte médica, cujo conhecimento não passou a seus descendentes por saber que a sanidade inscreve-se naqueles que vivem as boas leis na urbe, em sua respectiva ocupação, o que descarta a possibilidade do tempo livre para adoecer e o dispender a fim de se $\operatorname{tratar}^{73}$. É, pois, na indicação da excelência da polis que o médico tem seu ofício abrandado, decorrência da aquisição das virtudes pelos habitantes, tendo no alcance do Bem e do Belo, a elucidação da sanidade do corpo e do espírito. A Medicina, como já mencionado, intitulada de pedagogia das doenças por Platão, segue viés semelhante na Paidéia Poética, tendo na cura das moléstias uma espécie de misticidade ligada ao mundo do sagrado, visto que a saúde, cura da ignorância e das mazelas corpóreas, permite alcançar o Divino. É na referência a um deus, apresentado como médico na República, que se volta aos médicos-sacerdotes do Nilo que, por sua vez, sustentam a divinização de tais profissionaissagrados nos almanaques, fazendo da Paidéia médico-poética de almanaquias, a educação responsável pela cura dos males da modernidade que impedem a conquista do Sublime.

É o que se observa no almanaque brasileiro, pois ao se versar sobre a teoria dos quatro humores, notam-se semelhanças com as práticas médicas antigas supracitadas, visto que o Elixir Anti-Flegmatic age como "purgante lento", seguindo o princípio do tornar puro, purificar, limpar o organismo. Ele é misturado a um pouco de água e tomado pela manhã, uma ou duas colheres de sopa, "não debilitando, como todos os outros remédios desta natureza,

73. República, 406 a, b, c, pp. $116-117$. 
pois é tônico e refrigerante, assim como não obriga a reduzir as refeições, podendo também ser ministrado a crianças e pessoas de idade avançada". Diante de tal semelhança, é importante salientar a eficácia que o anúncio garante, posto que menciona o fato do tratamento mais racional ser aquele que atua sobre a doença, ou seja, como terapêutica do mal sem comprometer a sanidade do corpo, o que atesta a imensa reputação de que goza há mais de cem anos, o Elixir Anti-Flegmatic do Dr. Gillé, bem como os serviços prestados todos os dias a médicos e a doentes em casos desesperados. Então, "quer se trate de congestão, de doenças de fígado, de Coração, de gotta ou de rheumatismo, em uma palavra, de todas as affecções produsidas pelas flegmas ou excesso de biles, o emprego do Elixir Anti Flegmatic do Dr. Guillé, é maravilhoso."

Considerando a garantia de cura para todas as doenças causadas pela presença dos fleumas ou pelo excesso de biles no organismo, deve-se ressaltar o fato de que tal eficácia é assegurada também por meio do combate a falsificações do elixir, "recusando, implacavelmente, toda garrafa não trasendo por extenso as palavras Elixir Tonico AntiFlegmatic do Dr. Guillé, com a assignatura de Paul Gage". Também o texto informa o valor exato da panacéia, a 1/2 garrafa vendida, na França, no valor de $3 \mathrm{fr}$ e 50 , e a grande por 6 francos e em todas as farmácias. Também para aqueles que preferem remédios em frascos menores, buscando praticidade, em detrimento da "garrafada", tem-se a oferta das Pílulas de Extracto do Elixir Tonico Anti Flegmatic do Dr. Guillé, com as mesmas propriedades do Elixir. Quanto ao emprego das pílulas, não há necessidade de nenhum preparo especial, apenas uma ao jantar, como lanche ou de 2 a 4, em jejum, como purgante. O preço do frasco também é informado, $1 / 2$ frasco 2 francos e o grande 3 fr 50, igualmente em todas as farmácias da França, no laboratório correspondente situado em Paris, número 32, Rue de Grenelle, Saint-Germain. A leitura comparativa, Brasil-França, decorrente de tal anúncio, inscreve-se na oferta do medicamento francês a brasileiros, tendo sua autenticidade, concernente às propriedades tônicas tanto do elixir quanto das pílulas, garantida apenas no endereço francês, ou seja, os desassossegos e enfermidades da vida têm preço e logradouro parisiense. Em se tratando da chamada Belle Époque carioca, tal situação é prosaica, o que mais uma vez contribui, como outra pilastra feérica, para a edificação da ponte quimérica transportadora de sonhos entre as cidades ideais.

Isso posto, verifica-se que o Elixir Anti Flegmatic do Dr. Guillé funciona simbolicamente, na atmosfera místico-poética do Almanaque Garnier, como uma espécie de bálsamo para todos os males, desde um problema de fígado, até estados de melancolia 
causados pelos humores negros, ou seja, pelo excesso de biles negra geradora das consternações nos indivíduos, além de ser o invento capaz de prolongar a vida de forma ilimitada, de acordo com os desígnios dos elixires na história, tornando a vida aprazível e imune aos desprazeres, implicando no desenvolvimento integral dos leitores franceses e brasileiros, pelo alcance da Plenitude nas urbes excelentes do melhor dos mundos possíveis.

O mesmo princípio de longevidade e de vigor encontra-se no Élixir Henry Flach, do Almanach Hachette para o ano de 1905. Assim, o anúncio do elixir assegura a Guérison de L’Anémie - cura da anemia, dos estados agudos de fraqueza e das más digestões. Considerando a finalidade dos elixires no decorrer da história, observa-se o mesmo atributo no Elixir Henry Flach, uma espécie de remédio para todas as moléstias humanas, um Reconstituant Général, sorte de regenerador para todos os tipos de enfermidades, prolongando, de maneira incomensurável, a vida. O que simbolicamente se observa no $\boldsymbol{E}$ -

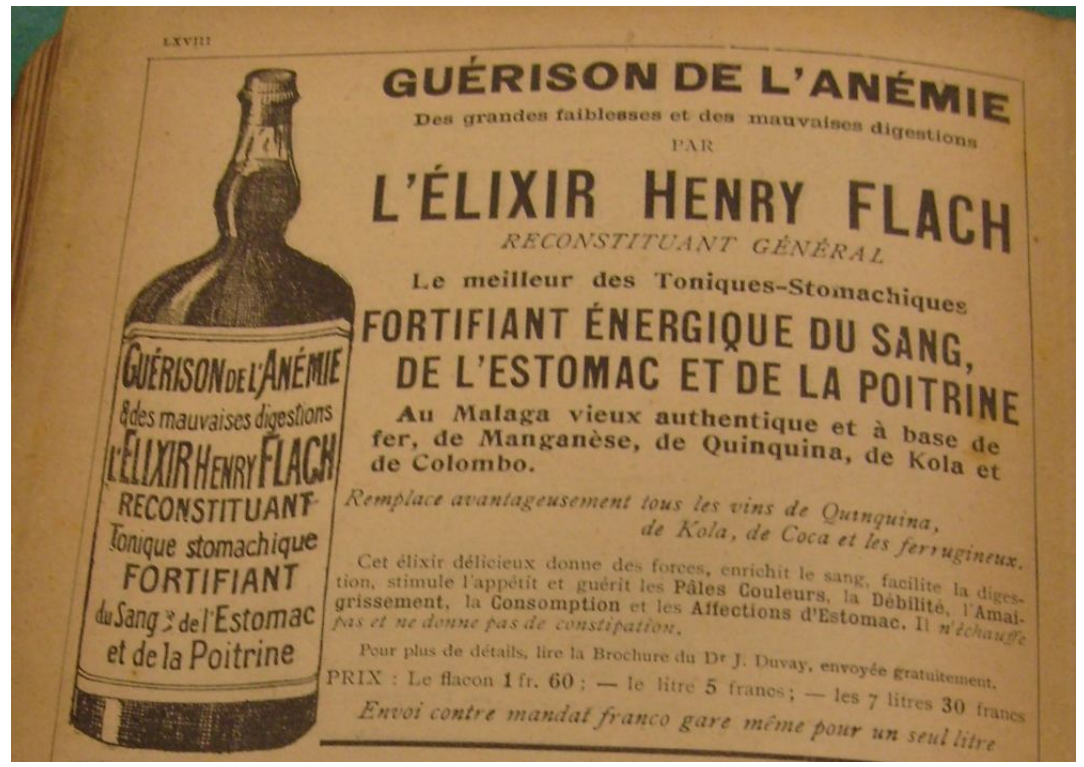

lixir Flach, visto que é prescrito para combater as intempéries diárias dos leitores, garantindolhes energia para cumprir seus afazeres cotidianos e combater as enfermidades, fomentando o microcosmo místico-poético criado pelo flâneur-poeta, a cidade excelente, sendo restaurador apenas pela leitura de seu anúncio, como uma espécie de antídoto mágico, em consonância com o viés maravilhoso, da feitura de almanaque. A Paidéia Poética que prescreve tal medicamento prodigioso vai ao encontro das considerações de Carneiro $^{74}$ ao apontar o fato da alquimia ter tido nos elixires de cura e revelação um de seus principais objetivos lendários, pois estes como a "pedra filosofal" ou o "dissolvedor universal", a busca pelas quintessências 
e pelos filtros, levaram muitos alquimistas a pagarem o preço cobrado pela Inquisição devido a manipulação do poder das plantas. Ora, o que se observa é que o Élixir Flach corrobora a atmosfera místico-poética dos almanaques aqui analisados, sendo um medicamento que apresenta toda uma simbologia de cura, fazendo o cunho médico-científico mesclar-se às raízes do sagrado, para atingir o caminho, calçado pelas pedras filosofais da cidade excelente, que leva ao Sublime.

O anúncio do Élixir Flach ainda garante que se trata do melhor dos tônicos estomacais "Le meilleur des Toniques-Stomachiques", bem como fortificante do sangue, do estômago e do peito "Fortifiant Énergique du Sang, de L'Estomac et de la Poitrine". Também é importante ressaltar a composição do elixir, combinado de autêntico vinho málaga envelhecido proveniente de Málaga (Espanha) e à base de ferro, de magnésio, de quinquina, arbusto ou pequena árvore da família das Rubiáceas, cuja cortiça contém alcaloides, dos quais o quinino tem propriedades medicinais reconhecidas, tônicas e que combatem a febre. Ainda, destaca-se em sua constituição a cola, Aurélio (2000, p.159) S. f. Árvore da família das esterculiáceas (Cola acuminata), cuja semente contém alcaloides tônicos e aperitivos. [Sin.: órobo, (BA) obi.]. Considerando sua composição, salienta-se a representação simbólica do elixir, o que direciona para o uso das plantas como patrimônio da cultura popular, sendo importante destacar o seu uso na antiguidade latina, como destaca Carneiro ao relatar que a utilização das ervas, as "artes de Emônia", era peculiar às feiticeiras, saber iniciático considerado feminino, característico não só do "menadismo báquico, das artes do transe, da possessão, como do curandeirismo mágico, da manipulação dos sortilégios". O autor ainda destaca, a questão de Ovídio citar as mulheres que, como Medéia, possuiam o conhecimento das plantas utilizadas para fins afrodisíacos. Também menciona o fato das plantas na Idade Média ter proporcionado uma prática de uso popular e de saber erudito proveniente de estudos alquímicos, o que foi chamado de filosofia natural, espagiria, arte de Hermes, nigromancia, magia ou, meramente, alquimia, conhecimento que buscava nas tradições antigas o poder das plantas, e que sofreu severas perseguições ${ }^{75}$. Tais componentes, em consonância com o microcosmo místico-poético de almanaque, levam a considerar que os leitores têm simbolicamente a receita diária para deleitar-se de "alcaloides tônicos e aperitivos à vontade", rememorando aqui o poeta Manuel Bandeira em sua Pasárgada, a fim de curar os

$75 \quad$. Carneiro, op. cit., p. 17. 
desassossegos do corpo e do espírito, para então, alcançar a Plenitude na cidade excelente, do Pays de Cocagne inserido na Terra sem Males de almanaque.

Tem-se ainda no anúncio a ênfase na eficácia do elixir, ao mencionar o fato de substituir vantajosamente qualquer outro vinho de Quinquina, de Kola, de Coca e os ferruginosos. Esse também, classificado como delicioso, dá forças, enriquece o sangue, facilita a digestão, estimula o apetite e cura as Pâles Couleurs - palidez, a Débilité - extenuação, o Amaigrissement - emagrecimento, a Consomption - enfraquecimento, e as Affections d'Estomac - infecções estomacais. Garante, além disso, não aquecer o corpo e não causar constipações. É mister salientar o fato de que na composição deleitosa do medicamento, temse substâncias, que de certa forma, ajudam o homem a suportar simbolicamente os dissabores diários, como o teor alcoólico advindo do vinho málaga misturado às ervas cola e quinquina, cujos alcaloides amenizam os suplícios físicos e espirituais, construindo uma espécie de mundo onírico, onde o vigor, o prazer e a longevidade são adquiridos por uma certa "embriaguez poética". Para maiores esclarecimentos, o anúncio informa que os leitores podem ler o encarte, do Dr. J. Duvay, enviado gratuitamente. Tem-se ainda o preço de tal panaceia informado, o frasco 1 fr. 60; o litro 5 francos e os 7 litros 30 francos, o segredo para a ventura de uma longa vida e para a cura de todas as moléstias.

Diante disso, o Élixir Henry Flach e o Elixir Anti Flegmatic simbolizam toda uma atmosfera mágica, elucidativa do microcosmo feérico criado nos almanaques francês e brasileiro, sendo o flâneur-profeta, pela Paidéia Poética educativa e diária, o manipulador da poção que cura mazelas de qualquer ordem e nutre os leitores com a fórmula tônica e curativa - a da longevidade - para adentrarem nas Repúblicas das delícias, Paris e Rio de Janeiro, representativas do alcance do Sublime

A oferta de vida longeva é recorrente nos almanaques franceses e brasileiros, como elucidação dos indivíduos sãos e virtuosos das cidades ideais, o que leva a considerar mais um exemplo do Almanch Hachette para o ano de 1907, a Tisane Du Chevrier. A angústia pela passagem inexorável do tempo é confirmada no anúncio da bebida à base de plantas, em que no primeiro parágrafo se coloca a problemática da longevidade como algo que mais aflige a existência humana. Diante disso, o texto atenta para o fato de que envelhecer conservando todo o vigor da juventude ou da idade madura é o que mais se almeja, o que solucionou o Dr. Mouly d'Aulus, ao compor a infusão prodigiosa. Considerando toda a simbologia intrínseca a tal bebida, observa-se que esta corrobora a atmosfera utópica de almanaque, visto que o segredo para Prolonger la Vie et ne Jamais Etre Malade, prolongar a 
vida e jamais adoecer, é descoberto com a composição da "infusão mágica", permitindo aos leitores a fórmula da saúde e da vida eternas, garantindo-lhes a imunidade diante de qualquer moléstia.

É nesse universo místico-poético que a bebida age, curando o corpo e o espírito dos leitores a fim de prepará-los para habitarem na urbe harmônica, sendo composta por quatro grupos de plantas, a ver: 1 . Depurativo - raízes de chicória/almeirão, da planta produtora de morangos selvagens, da paciência, flores de dandelion e de amor-perfeito selvagem. 2 . Laxativo - raízes de bryony, de elecampane, de bardana, de azevinho, folhas de buxo. 3. Diurético - fumária e parietaria. 4. Tônico aperitivo - genciana, flores de sábio, de pequenos centáureas-maior. Nesse microcosmo ideal, criado pelo flâneur-poeta, onde se tem solução para todas as problemáticas humanas, a bebida funciona simbolicamente, junto ao poder de suas plantas, como um remédio capaz de assegurar uma espécie de juventude eterna, ou seja, o viço conservado apesar da passagem inexorável do tempo. A farmacopeia poético-popular representada pelas plantas tanto dessa bebida quanto de tantos outros elixires, malgrado o teor científico elucidado, elaborados por doutores em laboratórios, assume relevância na vida social dos leitores dos almanaques, fazendo deles fiéis na crença da cura pelo poder da medicina popular, retirada do solo e em consonância com o universo do sagrado, mesmo porque a medicina, conforme o período em questão e segundo Carneiro $(1994$, p.75) "foi um dos últimos terrenos que o espírito cintífico conquistou”.

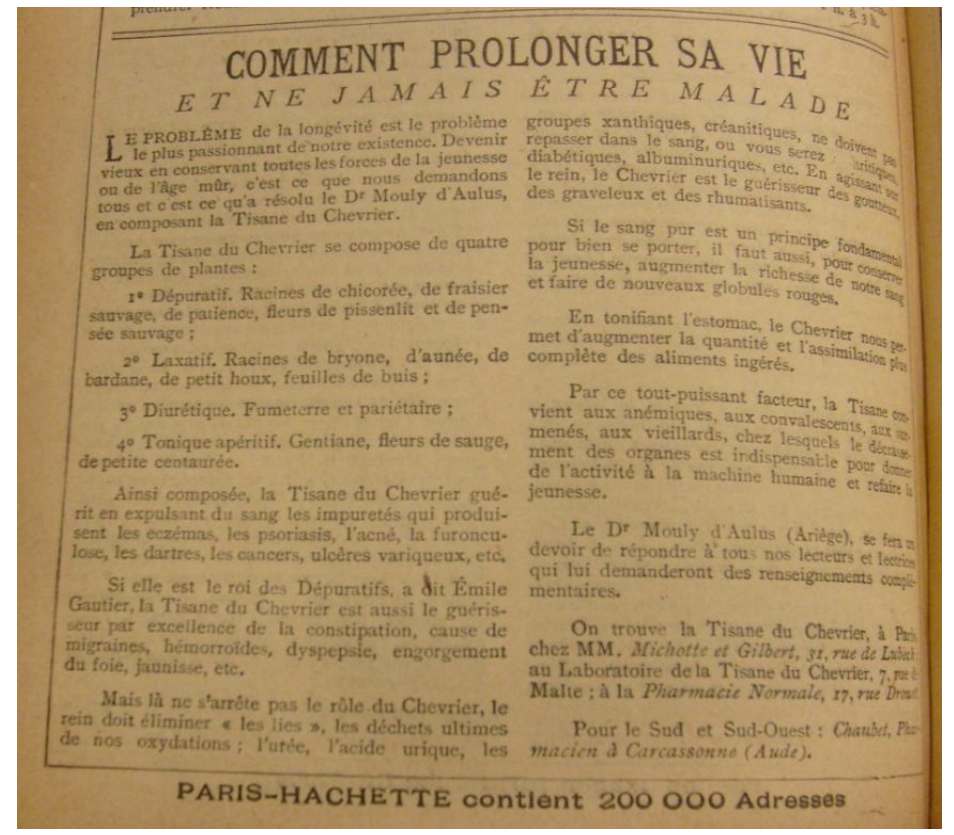


Destarte, classifica-se simbolicamente a Tisane du Chevrier, como uma "infusão mágico-terapêutica", como uma das peças para a construção do microcosmo místico-poético de almanaque, assegurando, concomitantemente, a sanidade dos habitantes da polis excelente pela eficácia de seu tratamento, deixando o sangue livre das impurezas que produzem os eczemas, as psoríases, a acne, o furúnculo, as doenças de pele, os cânceres, as úlceras varicosas, etc. No texto, Émile Gautier, possível leitora do almanaque francês e usuária de tal panaceia, apresenta o medicamento como rei dos depurativos, roi des Dépuratifs, - a cura, por excelência, da constipação, de enxaquecas, de hemorróidas, de dispepsia, de obstrução do fígado, de coloração amarelada, etc. Nesse processo de cura por meio do poder das plantas, que outrora eram consideradas sagradas, observa-se o papel do chevrier, pastor de ovelhas imagem que será analisada no próximo anúncio do mesmo medicamento - que se mostra simbolicamente como uma espécie de curandeiro dotado de sabedoria para manipular os poderes da natureza, sendo o responsável por tal "poção" que, por sua vez, também é eficaz em permitir aos rins a eliminação dos "lies", os dejetos de nossas oxidações: a utée, o ácido úrico, os grupos xantanas e créanitiques, que não devem passar para o sangue, pois são a causa de hiritiques, diabetes, albuminuriques, etc. Agindo nos rins, a tisana também é a cura para gotas, cálculos renais e reumatismos.

Nessa perspectiva, o depurativo tônico Chevrier garante seguir o princípio fundamental para o bem-estar do organismo, a pureza do sangue, que é imprescindível para conservar a juventude, aumentar a riqueza do sangue e refazer novos glóbulos vermelhos. Ele ainda, ao tonificar o estômago, permite aumentar a quantidade e a assimilação, mais eficaz, dos nutrientes oriundos dos alimentos ingeridos. Por conta desses poderosos fatores, a tisana é recomendada aos anêmicos, aos convalescentes, aos sobrecarregados, aos idosos, nos quais a limpeza dos órgãos é indispensável para ativar a máquina humana e reconquistar a juventude, simbolicamente eterna no microcosmo místico-poético de almanaque. Destaca-se novamente a temática da juventude reiterada incansavelmente nas páginas de tais livros herméticos, a conquista da longa vida, protelando obstinadamente a morte indelével, o que por meio de toda a simbologia da Tisane $d u$ Chevrier, proporciona o prodígio para a conquista da juventude eterna e a cura para todas as enfermidades, ou seja, o alcance do in illo tempore no microcosmo místico-poético, cuja longevidade representa o Tempo Sagrado, a nova Criação que transforma o morrer em viver eternamente nas ruas de ouro em pó das cidades excelentes.

Considerando a bebida que proporciona eterna juventude, além de afugentar a ameaça constante da morte por meio da cura de todos os males, o anúncio garante que o Dr. Mouly 
d'Aulus (Ariège), responderá a todos leitores e leitoras que pedirem informações complementares. A infusão com "poderes sagrados" das plantas pode ser adquirida em Paris, no estabelecimento M. M. Michotte et Gilbert, número 31, Rue de Lubech, também no Laboratoire de la Tisane du Chevrier, número 7, Rue de Malte ou na Pharmacie normale, número 17, Rue Drouet. Ainda assegura que para o Sud e Sud-Ouest, o medicamento é encontrado com Chaubet, farmacêutico em Carcassone. Diante da composição da tisana, constata-se que a medicina popular e a medicina erudita amalgamam-se no anúncio, e por conseguinte, nos almanaques, posto que a "infusão sagrada" advém dos poderes da natureza, de quatro grupos de plantas, manipulada por uma espécie de raizeiro/ervateiro/curandeiro, o chevrier - pastor, que possui sabedoria para desenvolver a fórmula de tal poção carregada de poeticidade. Diante disso, observa-se que apesar da fórmula ser desenvolvida à base de plantas, a infusão é certificada por um médico, Dr. Mouly d`Aulus, dotado de conhecimento científico, comercializada no Laboratoire de la Tisane du Chevrier, ou seja, em um estabelecimento especializado na manipulação de medicamentos segundo o saber e os padrões da medicina legitimada e tradutora da valoração da cientificidade condizente com o período da chamada Belle Époque.

Ora, tanto a sabedoria empírica do pastor, quanto o conhecimento de caráter científico do Dr. Mouly são apresentados no anúncio de forma similar, equiparando-se, não sobrepondo a medicina erudita do doutor à medicina popular desenvolvida pelo chevrier - pastor, ao contrário, a simbologia presente na figura deste último, reforça o viés místico-poético sustentado pelos almanaques, reforçando o caráter utópico de um microcosmo protegido dos males da modernidade pela associação de "remédios sagrados", proteção de santos, de signos, de astrólogos, etc. A sabedoria popular, que o chá simbolicamente representa, está em consonância com o homem do campo representado pelo pastor do anúncio, o que direciona para o que Oliveira diz sobre as comunidades rurais, o fato das plantas serem classificadas e selecionadas para as doenças e sintomas mais comuns que os lavradores conheciam, como gripe, dor de barriga, nervoso. Desse modo, alguns ervateiros e raizeiros preparavam garrafadas, preservavam a vida de homens e de mulheres por meio da atenção a lesões e mordeduras de cobras e de outros animais, cuidados classificados como uma medicina gerada para suprir as necessidades concretas de enfermidades e de aflições. $\mathrm{O}$ autor ainda elucida que após classificadas e selecionadas para cada tipo de moléstia e sintomas, as plantas podiam ser 
conhecidas pelos moradores, para então, serem utilizadas de maneira democrática e solidária $^{76}$.

É o que se tem na imagem do chevrier - pastor, uma espécie de homem do campo tomado de sabedoria concernente aos poderes da natureza, dotado de faculdades sagradas para tratar mazelas físicas e espirituais. Por isso, no outro anúncio do mesmo chá, La Tisane du Chevrier, do Almanach Hachette para o ano de 1908, tem-se mais uma vez o relato da manipulação, pelo pastor, de plantas, no Dépuratif exclusivement végétal, sendo " $\mathrm{O}$ mais agradável, o mais potente, o mais eficaz de todos os depurativos conhecidos". Ora, a medicina popular praticada pelo chevrier - pastor pode ser apreendida na imagem onde este aparece em seu habitat natural, de onde retira os segredos para todos os males, vestido de uma capa que denuncia seu estado de sacralidade, haja vista que a vestimenta, em questão, é utilizada por muitos sacerdotes em cerimônias eclesiásticas, bem como por inúmeras figuras sagradas.

Diante da caracterização carregada de misticidade, deve-se considerar o valor simbólico de tal personagem, que segundo Chevalier \& Gheerbrant em uma civilização de criadores nômades a imagem do pastor é carregada de simbolismo religioso. Também este comporta toda uma simbologia no que diz respeito a uma sabedoria que possui de forma intuitiva e experimental. Simboliza ainda a vigília, uma espécie de vigilante em constante atividade, "ele está desperto e vê". Por essa razão "é comparado ao sol, que tudo vê, e ao rei". Também, ao simbolizar o nômade, não apresenta raízes em um determinado lugar, "representa a alma que, no mundo, jamais é sedentária - está sempre de passagem". Quanto ao seu rebanho, "o pastor exerce uma proteção ligada a um conhecimento", julga o alimento que lhe pode ser fornecido, além de ser um "observador do céu, do Sol, da Lua, das estrelas", o que o faz capaz de prever o tempo. Diante disso, pode distinguir "os ruídos, escuta a chegada dos lobos ou o balido da ovelha desgarrada". Considerando todas as suas atividades, o pastor é considerado um sábio, “cuja ação deriva da contemplação e da visão interior"77.

76 . Elda Rizzo de Oliveira. O que é medicina popular? (São Paulo: Editora Brasiliense, 1985), p. 22 .

. Chevalier \& Gheerbrant. Dicionário de símbolos. pp.691 - 692. 


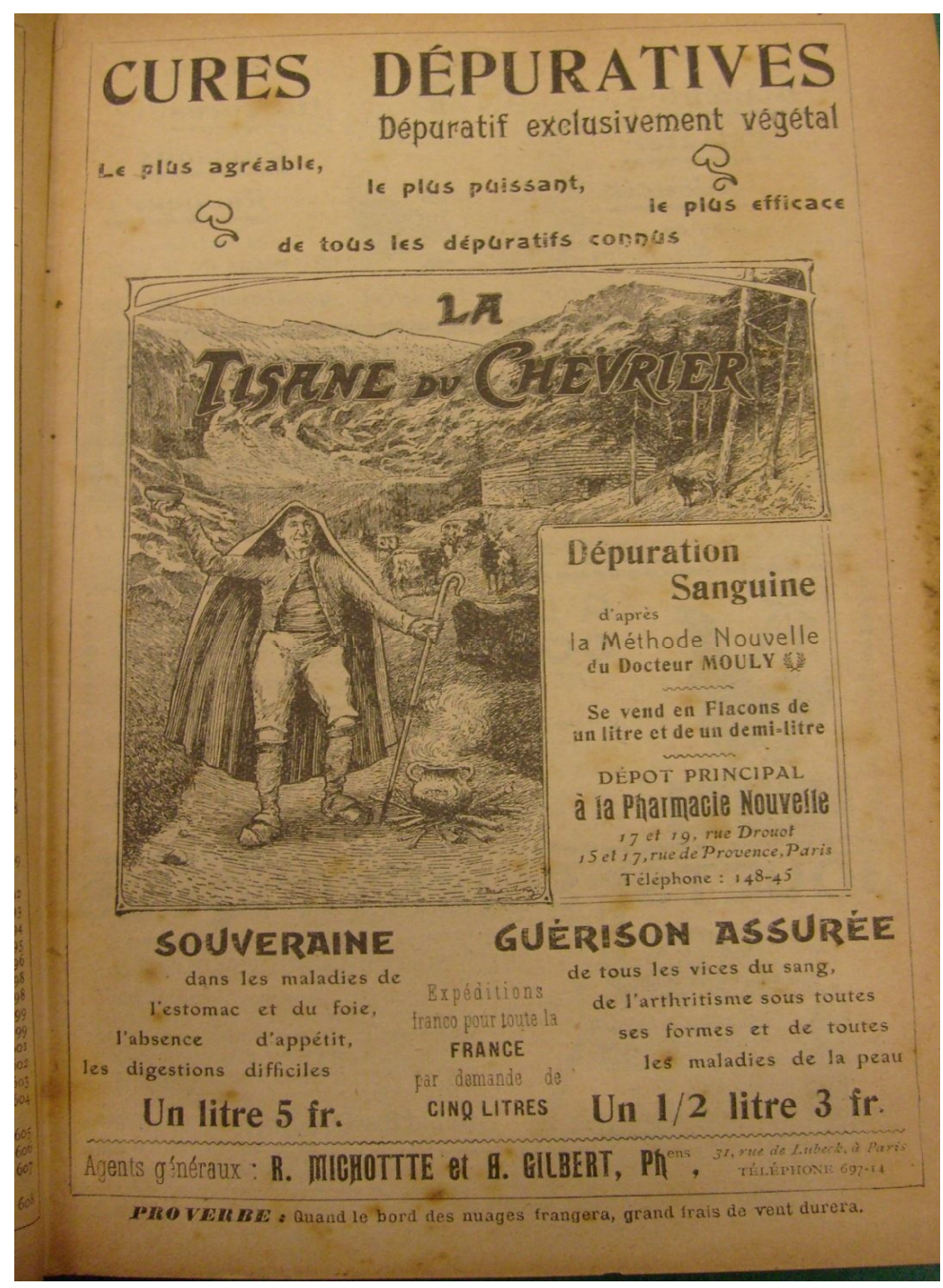

É tal simbologia que se considera para análise da figura do chevrier - pastor, visto que aparece no anúncio como um sábio que cuida de seu rebanho - leitores do Almanch Hachette, representado pelo flâneur-poeta com sua Paidéia Poética cotidiana, para que nenhuma ovelha saia da proteção de seu cajado e nem pereça com os males da vida. Possui o segredo para curar as enfermidades, representado pela poção que aparece fervilhando em uma espécie de caldeirão de barro sobre uma fogueira, no meio de montanhas, em um lugar longínquo e desocupado, apenas com um casebre à mostra. Ele é apresentado com um dos braços levantados, segurando a tisana que aparece, simbolicamente, como sendo a descoberta para a erradicação das mazelas humanas. Sua sabedoria, então, é extraída da natureza, das plantas e dos tantos segredos que o conhecimento do céu pode fornecer, além da intuição que lhe é inata, figura que até mesmo o tempo pode prever segundo a informação supracitada.

Baseado nas faculdades do pastor, observa-se que há toda uma simbologia no anúncio da Tisane du Chevrier, em que a "poção sagrada" é composta tanto pelas plantas quanto pela 
sabedoria empérica e intuitiva do guardador de ovelhas - leitores, seguindo uma terapêutica de purificação do sangue, limpando-o de toda impureza. Considerando tal expurgação sanguínea, deve-se retomar o fato de o chá seguir alguns princípios da medicina popular, o que remete para a cultura da purgação que, segundo Rocha, faz parte da observação e da demanda diária, muito mais que a simples utilização de plantas medicinais, pois constitui a base caracterizadora de tal medicina, o que pode ser traduzido por meio das expressões "sangue sujo, sangue grosso, podre por dentro, febre interna", que podem refletir um maior trabalho orgânico para expelir a morbosidade, a reima dos alimentos geradora da enfermidade, cujos efeitos reportam a uma alimentação indevida, ou seja, a purgação. Também menciona que é no meio popular onde se observa a utilização do laxante para facilitar a purgação em casos de diarréia, proporcionando, dessa forma, o procedimento capaz de recuperar o equilíbrio perdido por meio da eliminação da reima. $\mathrm{O}$ autor ainda cita que tal procedimento aplica-se a certas doenças da pele, quando determinadas raízes são empregadas e suscitam justamente a excitação dos sintomas, conduzindo assim à cura pela eliminação da moléstia, do material enfermiço ${ }^{78}$. Seguindo tal princípio da medicina popular que, por sua vez, segue a teoria da limpeza catártica realizada na Antiguidade, como já mencionado, observa-se que a Tisane du Chevrier age como um depurativo sanguíneo à base de plantas, Souveraine, soberana no que diz respeito ao poder curativo, pelo método da purgação, das doenças do estômago e do fígado, ausência de apetite e digestões difíceis. É baseada na crença coletiva da expurgação presente já nos primórdios, que o chá garante com a Guérison Assurée, cura indefectível dos vícios do sangue, a supressão da artrite em todas as suas formas e das doenças da pele.

É, pois, sob o princípio da medicina popular, de limpeza do sangue, que o chá age nos leitores do almanaque, bem como por meio de toda carga simbólica que este, junto ao chevrier, representa, e que também assegura o caráter médico-científico do medicamento, visto que se trata do novo método de depuração sanguínea do Doutor Mouly, La Nouvelle Méthode du Docteur Mouly. Diante disso, retoma-se a questão da medicina popular amalgamar-se à medicina erudita, posto que malgrado a composição da tisana ser à base de quatro grupos de plantas, tem-se a certificação de que sua manipulação é de responsabilidade de um médico, e não apenas dos poderes intuitivos do chevrier - pastor, o que remete ao fato

78 . Jorge Moreira Rocha. Como se faz Medicina Popular. Petrópolis: Editora Vozes, 1985, pp. $54-55$. 
de que nos almanaques o saber empírico mistura-se ao científico, alimentando tanto o universo místico-poético de tais livros herméticos, quanto seu caráter de formação, pela Paidéia, nas ciências humanas e na arte de bem-viver.

O que chama atenção em tal miscelânea, do popular com o erudito, é que tais saberes caminham sem nenhum tipo de conflito nos almanaques, direcionando à análise do poder ideológico na modernidade, ou simbólico como bem nomeou Bourdieu, contido em tal junção. Isso aponta para o fato de que é admirável não haver disputa em tal mistura, visto que no decorrer da história a medicina erudita sempre se sobrepôs à medicina popular, como legítima e baseada apenas no conhecimento científico, o que, muitas vezes, caracterizou a segunda como saber baseado em crendices e advindo de pessoas sem instrução. Então, a medicina popular é classificada como baseada na experiência, sem caráter científico, o que já de antemão apresenta a querela entre as duas, o que não é percebido em momento algum nos almanaques, havendo um concílio simbólico em tal situação. Essa harmonia leva ao que Oliveira aborda sobre a questão da identidade da medicina popular, relatando o fato de esta ser constituída e delimitada ideologicamente pelo mundo erudito: a religião erudita, a lei, a imprensa, a medicina erudita e os profissionais legítimos. Quem noticia ou classifica a medicina popular, como tal, é a medicina erudita. O responsável pela afirmação da política de quem pratica ou produz a medicina popular é o médico, "homem da lei, de estudo de escritura". Este dotado de conhecimento acadêmico, fala em nome da ciência apresentada e tratada como única, com autoridade e com reconhecimento que adquiriu na sociedade. (...) Diante disso, quando há inexistência de conflitos entre os profissionais da medicina erudita e da medicina popular, está presente de forma dissimulada. Ainda aponta que a peleja pode estar ocultada até mesmo pelo fato de alguns médicos reconhecerem que existe uma desigualdade concreta entre eles e os raizeiros, as benzedeiras e os ervateiros, mas sugerem uma igualdade formal. A autora ainda cita que essa igualdade apresentada parte dos valores que representam tais profissionais: parte da medicina, da ciência e do poder, nunca da cultura popular $^{79}$. Tal querela oriunda da modernidade é suplantada no anúncio inscrito no microcosmo de almanaquias, tendo na medicina popular representada pelos quatro grupos de plantas, pela simbologia do chevrier-pastor e a medicina erudita traduzida pela figura do doutor Mouly, a caracterização dos saberes articulados por tais livros herméticos, que ora advêm dos poderes do Universo e de suas representações, ora das ciências humanas tecidas ao longo da história. É, pois, com o intuito de adquirir a cura, para então, conquistar o verdadeiro 79 . Oliveira, p.63- 64. 
conhecimento, o alcance do Sublime no melhor dos mundos possíveis, que a tisana é simbolicamente ofertada aos leitores do almanaque, em garrafas de um ou meio litro, cujo depósito principal é a Pharmacie Nouvelle, situada às ruas Druot e Provence, em Paris.

Destarte, a Paidéia Poética segue a mimesis denunciativa e educativa concernente ao poder simbólico presente em tal disputa oriunda do mundo moderno, externo ao microcosmo místico-poético de almanaque, pois ao observar a representação da medicina popular e da medicina erudita, tem-se a questão da produção/consumo que visa o lucro pelo comércio da infusão. Tal fato que proporciona a garantia de venda a diferentes classes, que remete ao saber científico característico das classes letradas e também ao popular representativo do empirismo, leva à supressão de tal compartimentação pela costituição igualitária das polis excelentes, que têm na equidade dos entes sua máxima. É o que Bourdieu aponta como sendo:

O campo de produção simbólica, um microcosmos da luta simbólica entre as classes, pois ao servirem seus interesses na luta interna do campo de produção (e só nesta medida) que os produtores servem os interesses dos grupos exteriores ao campo de produção (BOURDIEU, 1930, p.12)

É no microcosmo místico-poético de almanaque, francês e brasileiro, que a miscelânea da medicina popular com a erudita corrobora a lisibilidade do erudito e do popular caminharem lado a lado, tanto no que concerne aos princípios medicinais, como na presença da literatura erudita vir mesclada a todo um arsenal popular de almanaquias. Ora, por meio de tal justaposição, a atmosfera ideal do Almach Hachette é reforçada, posto que apresenta cura para todas as enfermidades, visto que os males que não podem ser tratados pelo viés científico, como a passagem inexorável do tempo, consequentemente o envelhecimento e a morte, são assegurados por uma espécie de "depuração estética" que livra o sangue das reimas características da modernidade. Tais males impedem o desígnio de tal terapêutica, mas são sanados pela contemplação do Belo que, por sua vez, é resgatado por meio da miticidade tecida anualmante, com o auxílio da proteção dos santos, dos signos e dos astrólogos que garantem uma vida longeva e deleitosa no alcance do Sublime, na verdadeira idade de ouro, não a da chamada Belle Époque, mas a do princípio do mundo, aquela que não é sucedida por nenhuma outra.

Considerando novamente a pedagogia das doenças de Platão, nota-se que a cura das moléstias nos almanaques segue um percurso do microcosmo para o macrocosmo e viceversa, posto que é o segundo que inside no primeiro, patronando todas as ações e práticas de tais livros herméticos, como uma espécie de preparação dos leitores para a conquista do 
Sublime, ou seja, é na elucidação de uma mise-en-abyme místico-poética que se encontra o caminho didático para a Plenitude, a ver: flâneur-poeta> Paidéia Poética > médicos sacerdotes $>$ terapêutica de almanaquias divino-medicinal > leitores-pacientes $>$ Conquista do Sagrado. É, pois, o caminho educativo ministrado pelo flâneur-poeta, por meio da Paidéia Poética, que orienta com sua maestria-divina os médicos sacerdotes que, por sua vez, também logram faculdades sagradas, em consonância com tal microscosmo e com a prática medicinal em sua origem, cuja terapêutica de almanaquias divino-medicinal, prescrita aos leitores-pacientes, cura-os dos males do Tempo Profano para habitarem nas cidades excelentes representativas da nova Criação. Ora, a linha de chegada de tal trajetória educativo-poética permite que o macrocosmo ou o mundo superior simbolize a própria condição ideal das polis harmônicas, o microcosmo, fazendo com que o Céu desça ao chão de almanaquias e o Divino, com seus representantes, dirija as sessões de deleites que permitem sonhar com sítios resguardados das intempéries da modernidade.

Tendo em vista a Paidéia médica-místico-poética, retoma-se a figura do deus Asclépio representante dos médicos-sacerdotes dos almanaques, que tem semelhanças com o doutorsagrado egípicio I-em-hotep já mencionado, ambos após a morte tiveram diversos templos e santuários erigidos em sua glória que atuavam como hospitais. Para elucidação de tal terapêutica sagrada, indicam-se alguns dados sobre a vida do deus da cura e da medicina, que segundo Commelin é filho de Apolo e de Corônis, filha única de Flégias, rei da Boécia, tendo o monte Títio perto de Epidauro, no Peloponeso, sítio de seu nascimento. Tal união direciona ao vocábulo coronis que no grego significa gralha, tendo sido propagado que Asclépio teria nascido de um ovo desse pássaro, em forma de serpente. Tendo em vista o que se promulga na mitologia, Corônis foi morta por Diana ou por Apolo em decorrência de ciúme, tendo seu corpo já colocado na pira mortuária quando Mercúrio, quiçá o próprio Apolo, chega para fazer o parto de Asclépio. Em princípio o menino permanece sob os auspícios de uma ama nomeada Trigone, mas em seguida passa à escola do centauro Quíron, sítio onde faz rápidos avanços concernentes ao saber das plantas medicinais e à manipulação dos remédios, tendo sido consagrado pela capacidade e notoriedade com que praticou a arte de curar os ferimentos e as moléstias. Tal destreza terapêutica é ainda elucidada ao acompanhar Hércules e Jasão na expedição da Cólquida, sendo assaz relevante nos cuidados prestados aos Argonautas. Acrescenta-se que não satisfeito em curar os enfermos, Asclépio passa a ressucitar os mortos, sendo punido por Apolo devido à prática apropriativa dos poderes da divindade soberana e exterminado por Júpiter com um raio, mas após morto, 
continua-se a glorificá-lo com honras divinas. Cultos a tal entidade-médica foram celebrados em toda a Grécia, primeiramente em Epidauro, onde nasceu, tendo na representação de uma estátua de ouro e marfim feita por Trasimedes de Paros, um homem sentado num tronco com um bastão em uma de suas mãos e a outra apoiada na cabeça de uma serpente, com um cachorro próximo a si. $\mathrm{O}$ autor ainda menciona que o galo, a serpente, a tartaruga representam toda uma simbologia de sensatez e vigilância mister aos médicos, tendo, portanto, no templo de Epidauro a domesticação e alimentação de cobras, sendo cosenso que por meio de tal prática Asclépio manifestava-se ${ }^{80}$.

Ora, é por meio da elucidação da medicina e da cura combinadas ao sagrado, que os santuários ao deus Asclépio possuíam um templo, uma fonte para purificação e o abaton, lugar para repousar. Tais sítios ainda comportavam em grande número termas, jardins cultivados, um teatro, um ginásio e uma biblioteca, como representação da ritualística curativa tanto do corpo, quanto do espírito. É, pois, com tal direção divina que a Paidéia médica-místico-poética é exercida nos almanaques, tecendo nas cidades excelentes práticas terapêuticas semelhantes às dos santuários da antiguidade, simbolizando-as nas lições de cuidados com o espírito por meio dos santos, signos, astrólogos, até mesmo de lugar para repousar e de termas como mencionado na Station de Cure com suas vinte oito fontes da água sagrada Châtel-Guyon, tendo cinco buvettes para devoções regulares. Tal similitude ainda é observada na caracterização divinizada dos doutores com seus medicamentos para sanidade do corpo e, também, na pedagogia diária com suas sugestões de peças e de teatros, de literatura e de cultivo em uma espécie de biblioteca domiciliar, viés pelo qual tais livros herméticos mantêm a própria essência de tais sítios consagrados, onde se conquista a mais alta arete condutora do Sublime.

Desse modo, a Paidéia médica-místico-poética prossegue na orientação dos leitores, receitando longevidade e cura nos almanaques, que representam simbolicamente livros sagrados com fórmulas para erradicar os males da vida, proporcionando um mundo utópico, no qual até mesmo a morte, certeira para todos os homens, é extirpada. Nessa perspectiva, tem-se mais uma fórmula para exterminar as moléstias, agora dos pulmões, bem como a ameaça de fenecimento lisível no anúncio do Xarope Peitoral de Alcatrão e Jatahy, do Almanaque Brasileiro Garnier para o ano de 1908. Observa-se toda uma simbologia na

$80 \quad$. Commelin, p.176, 177 e 179. 
propaganda que, por sua vez, está em consonância com o universo quimérico de almanaque, onde se encontra cura e bem-estar, direcionando à análise da imagem que apresenta três figuras de um mesmo enfermo, a primeira referente ao estado inicial do doente, de aspecto debilitado, tossindo ininterruptamente, com o seguinte dizer Eu Era Assim, a segunda representando-o por meio da cabeça de uma caveira, indicando a gravidade da moléstia, seguida pela frase Cheguei a Ficar Quase Assim, e a terceira um belo homem que em nada parece com a imagem inicial, finalizando com uma exclamação, consegui ficar assim!! Completamente Curado e Bonito. É interessante notar que o Xarope Peitoral ultrapassa simbolicamente os efeitos de um medicamento indicado para curar moléstias do pulmão, este tem poderes estéticos, pois consegue a proeza de tornar a pessoa bonita, ou seja, novamente a elucidação, mesmo que um tanto quanto jocosa devido ao tom trágico-humorístico do discurso, da cura do corpo para o alcance do Belo.

Ao mencionar o poder de cura de tal medicamento, extirpando a sombra da morte, figura aterrorizadora que assombra os seres desde os primórdios, não é possível deixar de discorrer sobre a sua simbologia, que segundo Chevalier \& Gheerbrant é o fim absoluto de algo positivo, a vida do ser humano, um animal, uma planta, uma amizade, uma aliança, a paz, uma época. Por isso, não se fala de morte, por exemplo, de uma tempestade, mas de um belo dia. Enquanto símbolo, a morte indica o aspecto perecedor e destrutível da existência, o que denuncia o desaparecimento judicioso na evolução das coisas: ela se liga à simbólica da terra. Também é a introdução nos mundos desconhecidos, do Inferno e do Paraíso, o que mostra a sua ambivalência, como a da terra, e a aproxima de certa forma aos ritos de passagem. Ela é revelação e introdução. Assim, todas as iniciações atravessam uma fase de morte, antes de permitir o acesso a uma nova vida. Nesse sentido, os autores elucidam que ela apresenta um valor psicológico, extingue das forças negativas e regressivas, desmaterializa e libera as forças de ascensão do espírito. Se ela é filha da noite e irmã do sono, possui como sua mãe e sua irmã o poder para regenerar ${ }^{81}$. É o que se observa no anúncio do Xarope Peitoral, visto que ele afugenta a sombra da morte simbolizada pela cabeça da caveira e cessa simbolicamente o processo de perecimento da existência encadeado pelas doenças descritas.

Logo, o homem, acometido por um mal, abre-se para uma nova vida após ter feito o tratamento com o milagroso medicamento que tem poder até mesmo para embelecer, o que se

81 . Jean Chevalier \& Alain Gheerbrant. Dictionnaire des Symboles (Paris: Robert Laffont/Jupiter, 1982), p. 650. 
deduz antes feio e combalido, agora é belo e são pela eficácia do xarope. É interessante notar que o xarope além do poder medicinal proporciona simbolicamente uma nova vida aos leitores do almanaque brasileiro, pois o enfermo quase chega ao estado da caveira a fim de

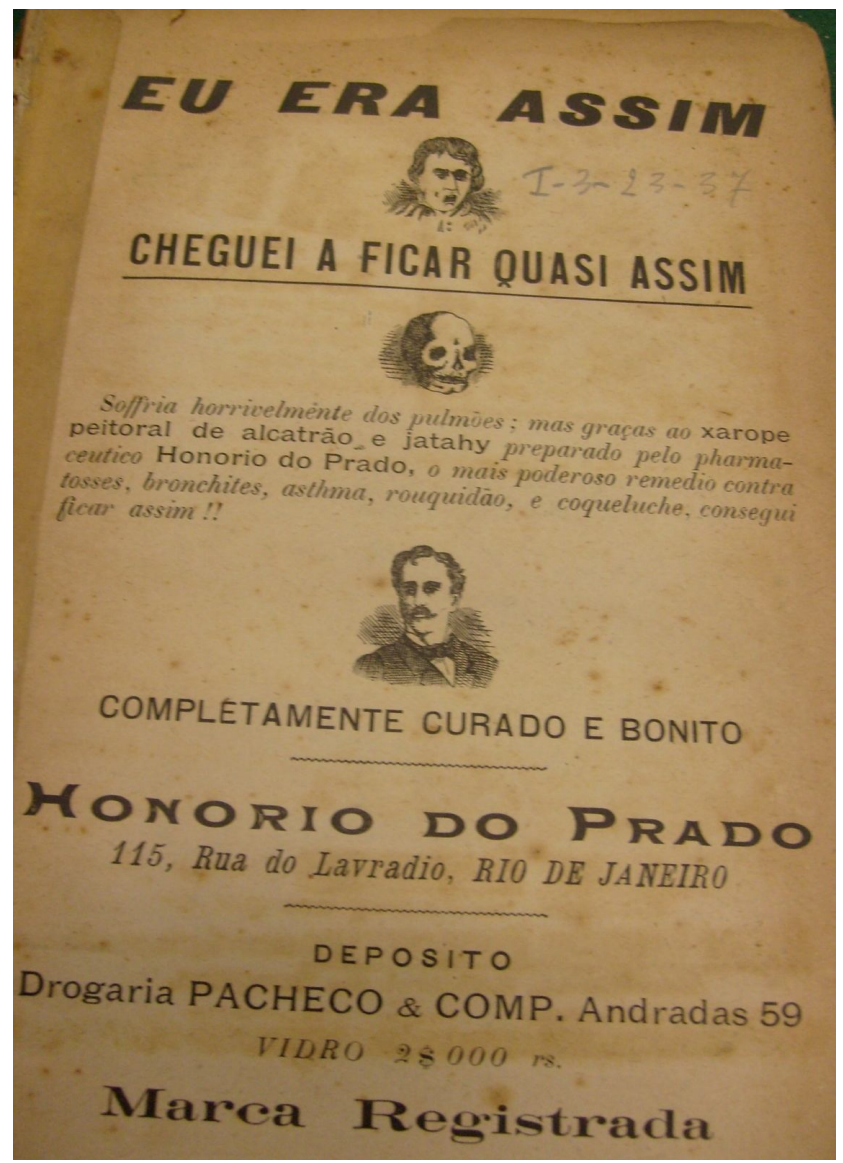

renascer forte, belo e completamente curado para a nova Criação. É nessa perspectiva que se inscreve o anúncio do xarope, visto que o discurso apresenta um enfermo que "Soffria horrivelmente dos pulmões; mas graças ao xarope peitoral, de alcatrão e jatahy preparado pelo pharmaceutico Honorio do Prado, o mais poderoso remedio contra tosses, bronchites, asthma, rouquidão, e coqueluche", conseguiu ficar inteiramente sarado e bonito, o que chama atenção para a linguagem notadamente persuasiva da propaganda, exemplificando por meio da cura do doente, que se trata de um medicamento extremamente confiável e eficaz, tanto para o combate das enfermidades, quanto para a supressão da fealdade, curando o corpo e o espírito com a preparação prodigiosa do boticário, em consonância com o microcosmo místicopoético de almanaquias, para alcance da Plenitude.

É na Rua do Lavradio, número 115, Rio de Janeiro, onde se adquire o prodigioso xarope, cuja simbologia permite aos leitores do almanaque a cura de enfermos desenganados, em estado mortificado. Também pode ser obtido na "Drogaria Pacheco \& Comp. Andradas 
59”, em seu Depósito, no valor de 2 \$ 000 rs, havendo "Marca Registrada" que assegura não se tratar de engodo.

Logo, pode-se dizer que o Xarope Peitoral é um medicamento que sustenta simbolicamente a atmosfera quimérica do Almanaque Brasileiro Garnier, na medida em que tem poder para curar as doenças dos pulmões em casos que se havia, possivelmente, perdido a esperança, tendo no discurso da persuasão a chave para a crença de que a morte é banida e uma nova vida conquistada, a do in illo tempore, combinada à nova Criação anuária, possibilitando a reiteração e o alcance do mote da vida longeva, incessantemente na mística de tais livros herméticos, inscrita no Sublime.

A Paidéia médico-poética que assegura longevidade e supressão da finitude no melhor dos mundos possíveis ainda é elucidada no Almanaque Brasileiro Garnier para o ano de 1914, a presença reinventada da figura da morte por meio do medicamento Arsiquinine Lemaïtre. A estetização da morte em tal sítio maravilhoso permite a garantia da vida, ou melhor, da vida longeva, que sustenta o imaginário coletivo dos leitores, proveniente das "fórmulas de felicidade" inscritas nas almanaquias que permitem sonhar. Desse modo, observa-se mais um exemplo que permite analisar as temáticas tanto da vida quanto da morte nas cidades excelentes, bem como da longevidade, o que se observa já no início da propaganda com o título Salvação dos Paludicos. Considerando tal promessa de cura, destaca-se o vocábulo "salvação" que traduz em consonância com a atmosfera místico-poética dos almanaques, o indulto tanto físico quanto espiritual, posto que o segredo para as inquietações humanas é encontrado nas tantas almanaquias da cidade ideal, na proteção dos santos com seus respectivos dias, nos astros, nos signos e nos astrólogos da Terra sem Males.

$\mathrm{Na}$ oferta de cura observada nos almanaques, reforçada pela propaganda, nota-se que tanto a linguagem verbal quanto a não-verbal refletem o discurso da salvação, pois no texto vê-se toda uma simbologia de livramento perante a fúnebre que chega com sua foice, a morte. Diante de toda a simbologia que a temática da morte sustenta, observa-se ainda que segundo Chevalier \& Gheerbrant o esqueleto armado de uma foice com uma lâmina dispensa comentários, fala por si mesmo. Inteiramente rosado e não dourado, apresenta um pé firmado na terra, tem na mão esquerda uma foice cujo cabo é amarelo e a lâmina vermelha, cor de fogo e de sangue. Isto é para nos advertir que a morte que ele representa não é a morte individual, mas a destruição que ameaça nossa existência espiritual se a Iniciação não a salva do aniquilamento ${ }^{82}$ É justamente

82 Jean Chevalier \& Alain Gheerbrant. Dictionnaire des Symboles ( Paris: Robert Laffont/ Jupiter, 1982), p. 651. 
esta figura que ameaça o enfermo na propaganda do Arsiquinine, pois os que sofrem de paludismo são ameaçados pela sombria tétrica com sua foice que, por sua vez, é combatida pelo anjo que traz simbolicamente a salvação, como um milagre que desponta em meio ao quarto fúnebre. Tal é a surpresa/gratidão pelo medicamento, que a provável acompanhante é apresentada na imagem com os joelhos levemente flexionados e os braços estendidos, como se estivesse diante da solução prodigiosa para o fim do sofrimento do doente. Logo, a morte que se apresenta funérea e sempre impetuosa, agora se esquiva diante da sacralidade do anjo, como vencida pelo poder do medicamento sagrado. É na luta entre o bem e o mal, que o Arsiquinine funciona como agente responsável pela paz e consequentemente por uma espécie de ressurreição do enfermo, também dos leitores, em consonância com o microcosmo místico-poético de almanaque, tendo no Sagrado a salvação do Tempo Profano de mazelas do corpo e do espírito na modernidade.

É o flâneur-poeta, por meio da Paidéia Poética, que prescreve tal medicamento, com uma espécie de bula informativa e salvadora, inserindo no microcosmo excelente, mercado terapêutico de deleites, o anúncio cujo discurso é carregado de simbologia e de sacralidade. De antemão, tem-se em letras grandes que tal remédio Cura Sempre, ou seja, a confirmação de sua eficácia em relação ao "paludismo, as doenças do fígado e do baço, as febres ou sesões intermitentes, a anemia palustre". Em seguida observa-se a garantia de que se trata não apenas de um remédio que, como simbolizado na propaganda, tem poderes miraculosos para curar até mesmo aqueles que jazem gravemente no leito da morte, mas de precaver males como, "o paludismo e todas as suas manifestações, e consecuencias, mata os micróbios das febres, não cansa o estomago", o que atesta ser um Preventivo Seguro. Nota-se mais um fato que corrobora o poder de persuasão do discurso, posto que o Arsiquinine "É um Tônico poderoso", sendo o vocábulo "poderoso" carregado de simbologia concernente às suas propriedades fortificantes, dando a entender que é indicado para tratar moléstias as mais graves. Ele ainda é "Soberano contra a grippe e a influenza", o que fortalece o seu poder de ação no combate às doenças, bem como na persuasão dos leitores para a compra do prodigioso medicamento. 


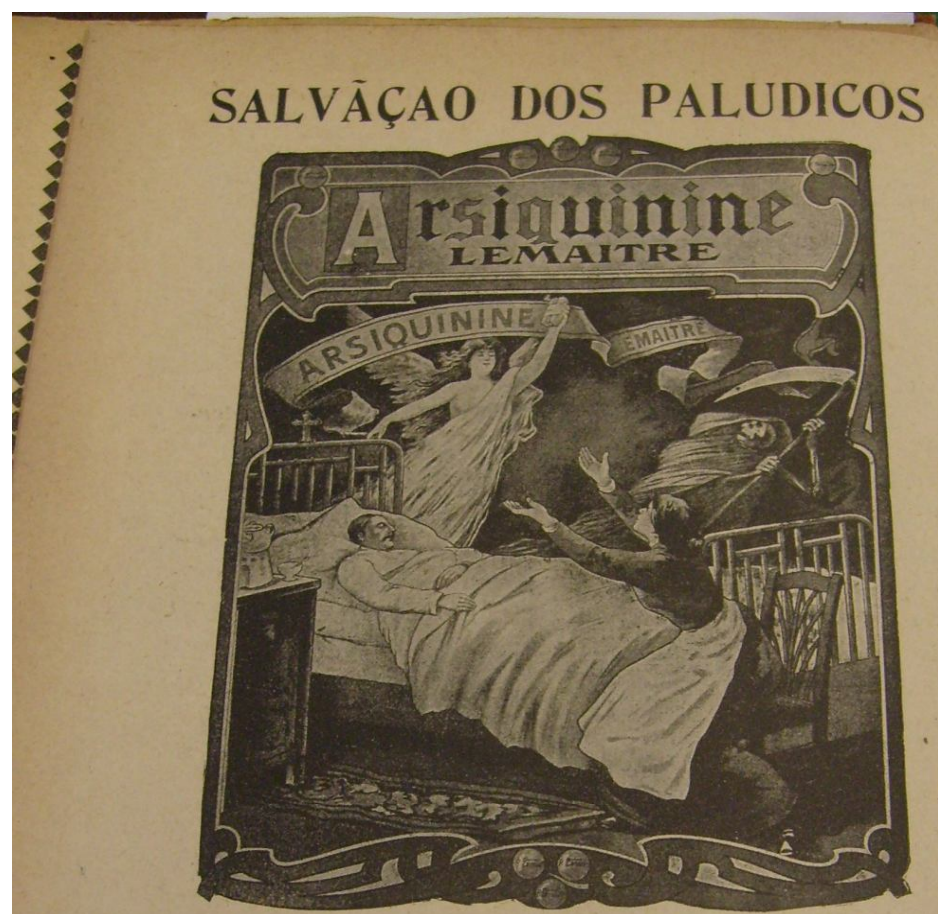

Cura sempre: $O$ paludismo, as doenças do figado e do baço, as febres ou sesões intermitentes, a anemia palustre.

Preventivo seguro: Contra o paludismo e todas as suas manifestações, e consecuencias, mata o microbio das febres, não cansa o estomago.

E um tónico poderoso.

Soberano contra a grippe e a influenza.

Vende-se em vidros de 30,60 e 100 tabloides - Exija-se em cada vidro o nome registrado de

\section{AR S I Q U I N I N E}

e em cada tabloide, assim como nas cintas de garantia que cercam cada vidro fac-simile da assignatura : R. LEMAITRE.

Em todas as Pharmacias e Drogarias

Por atacado : BONETTI FRERES, 12, rue Vavin, PARIS

O poder do soberano tônico para livrar os leitores da finitude, por meio do anjo salvador, em consonância com o microcosmo místico-poético de almanaque, remete à simbologia do Hades, elucidada no Mito de Er platônico, da República, fazendo das polis excelentes, Paris e Rio de Janeiro, sítios protegidos tanto das ameaçadoras moléstias circundantes, quanto da descida indesejada. Ora, para elucidação da temática do fenecimento reiterada ao longo das sessões de almanaque, é mister apresentar a morte de Er, homem destemido, filho de Armênio, que desceu ao Hades devido à participação em uma guerra, tendo seu corpo sido resgatado em perfeito estado após dez dias entre os cadáveres decompostos. De tal resgate foi levado a sua casa para ser sepultado, o que não sucedeu, posto que no décimo segundo dia, ao ser colocado 
sobre a pira, reviveu e relatou tudo o que vira de tal experiência. Então inicia com a menção de que após ter deixado seu corpo, sua alma caminhou com muitas outras até um sítio surpreendente onde se encontravam duas aberturas, uma ao lado da outra, e no céu, outras duas que davam para as primeiras. Em meio a essas aberturas estava sentado o júri que, após dar seu veredicto, encaminhava os justos à direita para o caminho que conduzia ao céu, tendo atado no peito a indicação de sua sentença, ao passo que os injustos eram direcionados à esquerda rumo à parte inferior, traduzido também, mas nas costas, o indício concernente a tudo o que haviam praticado. Diante disso, Er acrescenta em seu diálogo com Glaucon, que na medida que as almas iam distanciando-se para cada uma das aberturas sentenciadas do céu ou da terra, observou que de uma das outras duas saíram almas descoradas e cobertas de pó, e da outra almas que desciam puras do céu. Prossegue com a elucidação de que as almas conversavam entre si perguntando umas as outras o que se passava em cada lugar, então algumas falavam chorando que sofreram dores, rememorando os tormentos a que foram submetidas e o que viram em sua passagem pela terra, caminhada de mil anos, enquanto as outras, que vinham do céu, relatavam a ventura que sentiram e a beleza da extraordinária contemplação diante de seus olhos ${ }^{83}$. É justamente de tal passagem pelo Hades que a Paidéia Poética livra os leitores, utilizando-se de suas almanaquias deleitosas - como o tônico vigoroso trazido simbolicamente pelo anjo resgatador do sítio tétrico em que se encontram os indivíduos ceifados pelas moléstias mencionadas no anúncio - fazendo do juízo concernente aos homens justos e injustos, a pedagogia salvadora de todos os habitantes para adentrarem nas polis excelentes, visto que a descida já não existe na nova Criação, pois os males da modernidade, representativos dos caminhos tortuosos, são curados pela conquista da mais alta Arete condutora da Plenitude. Ora, é no próprio abaixamento do Céu que tal beleza indescritível é tecida no microcosmo místico-poético de almanaque ou nas cidades ideais, abolindo a finitude em suas ruas de ouro em pó, fazendo da temerosa passagem, que assombra a humanidade desde os primórdios, o alcance da Terra não apenas Prometida, mas alcançada pela Poiésis tecedora do Sublime.

Diante do discurso persuasório presente no anúncio, é importante mencionar o raciocínio discursivo que este segue, o que leva a considerar o que Citelli ${ }^{84}$ aponta como raciocínio apodítico (apodeiktkós) que possui o tom da verdade inquestionável. Então, é possível observar o mais completo dirigismo das idéias, o que impede qualquer dúvida quanto à veracidade do

83 . Para melhor compreensão do Mito de Er, ler diálogo entre Sócrates e Glaucon do livro X da República, pp. 409 -410.

84 . Adilson Citelli. Linguagem e Persusão (São Paulo: Editora Ática, 1991), p. 18. 
emissor em relação à argumentação, visto que esta é realizada de maneira extremamente cerrada. O que é tomado como base para a análise de dois exemplos da propaganda do Arsiquinine:

Exemplo: É um Tônico poderoso.

Raciocínio implícito: Se você quer ficar forte e prevenido contra as doenças, deve tomar o Arquisine.

Exemplo: Soberano contra a grippe e a influenza.

Raciocínio implícito: Se você quer se ver livre da gripe e da influenza, deve tomar o Arquisine.

Diante dos exemplos baseados na análise do autor de Linguagem e Persuasão, observase ainda que ele chama a atenção para o caráter imperativo do verbo, o que torna o enunciado indiscutível. Desse modo, o receptor fica coibido de esboçar qualquer indagação. "É um raciocínio fechado em si mesmo que não dá margem a discussão". É o que se observa na propaganda do Arsiquinine, pois o receptor/leitor do almanaque brasileiro é levado a acreditar plenamente na eficácia do medicamento por meio do discurso persuasivo característico do mercado moderno, sendo tão poderoso e soberano, que tem poder para livrar os doentes do leito da morte, como observado na imagem do quarto de um enfermo, bem como de reforçar o microcosmo de salvação do almanaque das moléstias do mundo circundante. A linguagem convincente é reiterada ainda por meio da garantia do produto, alertando os leitores de que o legítimo medicamento deve obrigatoriamente apresentar "em cada vidro o nome registrado de Arsiquinine e em cada tablóide, assim como nas cintas de garantia que cercam cada vidro facsimile da assignatura: R. Lemaitre". Logo, o que se tem como discurso é a eficácia do remédio, a segurança de seu registro e de sua assinatura pelo R. Lemaitre, o que implicitamente leva os leitores a crer em seu poder e seriedade, levando-os ao convencimento de seus efeitos prodigiosos. Assim, os leitores do almanaque brasileiro podem adquirir o remédio importado "Em todas as Pharmacias e Drogarias", ou "Por atacado: Bonetti Frères, número 12, Rue Vavin, Paris", reforçando a prática da chamada Belle Époque carioca em adquirir produtos franceses pela passarela quimérica que intercambeia "analgésicos de ventura" para sanidade do corpo e do espírito dos habitantes, a fim de torná-los aptos para adentrarem nas polis excelentes do melhor dos mundos possíveis.

Considerando a linguagem persuasiva e a simbologia presente no anúncio do Arsiquinine, nota-se que o microcosmo feérico do Almanaque Brasileiro Garnier é corroborado, proporcionando cura para os desenganados por meio da salvação da morte, da prevenção das doenças, consequentemente da oferta de logevidade, além de incutir nos 
leitores a crença na soberania de tal medicamento, tornando-o superior perante os demais por estar em consonância com o universo místico-poético de tal livro hermético.

Diante da cura para o corpo e para o espírito com o medicamento Arsiquinine, ofertado pelo anjo que livra os leitores do Garnier da foice certeira da morte, observa-se outro remédio que reforça simbolicamente o universo excelente dos almanaques, posto que age como panacéia para todos os males, ora para tratamento de doenças, ora para apaziguar dores da alma. Desse modo, a Paidéia Poética receita a terapêutica de onirismo com o Grande Liqueur Française Bénédictine no Almanach Hachette para o ano de 1912. Considerando tal medicamento em consonância com a mística-poética de almanaquias, nota-se que ele apresenta o álcool como um de seus componentes, levando a inferir que não se trata de um licor comum, mas de um licor/remédio - Exquise - delicioso, Tonique - tônico e Digestive digestivo. Diante disso, é importante atentar para o significado do vocábulo "licor", que segundo Aurélio, é S. m. 1. Bebida aromatizada e doce, obtida pela mistura de álcool ou aguardente com substância geralmente de origem vegetal, adicionada de sacarose, glicose ou mel. 2. Designação comum a vários produtos líquidos (químicos ou farmacêuticos), especialmente àqueles em cuja composição entra o álcool. 3. Desus. Humor (1). 4. Qualquer líquido. 5. O conteúdo de um cálice de licor $(1)^{85}$. Logo, o que se tem simbolicamente como medicamento é uma mistura de todos os itens, uma "bebida" exquise - deleitosa que leva para a definição da palavra licor - doce e aromatizada, de teor alcoólico, adicionada de sacarose, glicose ou mel. Ora, além de passar a mensagem aos leitores do almanaque francês, de que se trata de um medicamento com propriedades destinadas ao deleite, como um "néctar dos deuses", ainda assume o papel terapêutico a que é destinado, tonificar e facilitar a digestão.

Nesse sentido, considera-se o Bénédictine como um medicamento verdadeiramente bendito, que veio exclusivamente para livrar os leitores das enfermidades físicas e espirituais, posto que é um licor simbolicamente abençoado, tem poderes que ultrapassam a racionalidade do mundo científico. Toda a simbologia do anúncio remete para uma questão um tanto quanto interessante, pois assim como se observa a questão do "Embriagai-vos" baudelairiano com a bebida que acalma as inquietações humanas, também assistimos a uma sacralização do profano, na medida em que o álcool, censurado no âmbito religioso, é indicado aos leitores do Almanach Hachette como bebida que fortalece a alma, eliminando qualquer sentimento de culpabilidade. Sendo assim, para certificação da beatitude proporcionada pelo licor, de transformação simbólica do profano em sagrado no microcosmo místico-poético, encontra-se

$85 \quad$ Aurélio, 2000, p. 394. 
o símbolo de uma cruz, que de antemão garante santidade, além de apresentar uma indicação de D.O.M Le Dirtctrs que representa segundo Aurélio (2000, p. 229) "S. m. Forma de tratamento dada a reis, príncipes e nobres e dignatários da igreja católica, sempre seguida do nome de batismo". O deleitar-se no labéu que agora é símbolo de sacralidade vem simbolicamente orientado por uma autoridade eclesiástica - que recomenda o licor de maneira extremamente convincente, como uma espécie de culto báquico liberto de seu valor profano pois assina com seu nome de batismo a bebida que cura e alegra, com seu teor alcoólico, o es- 


$$
\mid
$$


pírito. Essa santa aprovação ainda pode ser observada no carimbo do lado esquerdo da propaganda, no qual está estampada a figura de um dignitário da igreja, possivelmente do mesmo que assinara tal medicamento, o que persuade ainda mais os leitores do almanaque e reforça a misticidade de tal microcosmo quimérico, visto que ele não é apenas assinado, mas carimbado. Do lado direito, tem-se mais um símbolo de certificação que funciona como elemento persuasivo, uma espécie de brasão que assegura a origem do produto, além dos dizeres em latim que reforçam o tom sagrado e o caráter erudito de tal medicamento: Liquor,

\section{Abbatle Fiscanens.}

O caráter sagrado do medicamento, cuja figura do clérigo é a própria representação do poder santificador, remete, de forma semelhante, ao almanaque francês, ao rebaixamento do Céu ao microcosmo místico-poético de almanaquias, fazendo de tal descida transformadora do profano, os males da modernidade, a Criação de um paraíso inscrito na cidade excelente, a própria constituição dos Campos Elíseos como mansão celeste na Terra, que segundo Commelin, é a morada ditosa das almas virtuosas na mitologia grega, oposta ao Hades, onde reinava uma primavera infindável, com abundância de verdura, folhagens, flores e frutas. Em tal idílio, à sombra dos arvoredos perfumados, dos bosques, da multiciplidade de rosas e de murtas alegrados pelo canto e chilrear dos pássaros, regados pelas águas do Lete sussurradoras de uma melodia branda, as almas venturosas deleitavam-se em um excelente repouso e usufruíam de uma juventude perene, sem desassossegos, tampouco suplício. Neste, recostados em leitos de asfódelo, planta de folhagem macilenta, ou preguiçosamente sentados na vegetação de frescor agradável, os heróis narravam uns aos outros suas proezas, ou escutavam os poetas exaltarem seus feitos em versos de um júbilo fascinante. $\mathrm{O}$ autor resume, então, que nos Campos Elíseos foram reunidos todos os enlevos e deleites, ao passo que no Inferno dos réus, toda sorte de padecimentos ${ }^{86}$. É, pois, na tessitura do microcosmo místicopoético de almanaque como sítio divino, onde os leitores têm acesso às almanaquias que permitem a cura para as moléstias do corpo e do espírito, que se observa o remédio ou a ambrosia dos deuses - santos, astrólogos, signos, eclesiástico representativo do sagrado, etc responsável simbolicamente pela supressão da descida ao subterrâneo lúgubre, ou melhor, a finitude certeira, visto que suas propriedades agem como terapêutica para o alcance do ser que não modifica com o decurso do tempo, mas se inscreve na conquista, pela Poiésis, do Sublime nos Campos Elíseos verdejantes e sagrados da República das delícias.

$86 \quad$. Commelin, p.185. 
É no discurso persuasivo que a crença mistura-se ao princípio médico-científico do licor, remetendo novamente à combinação entre a crença oriunda da medicina popular e a medicina erudita de tais livros populares. O discurso religioso é fundamental para o convencimento dos leitores sobre os poderes científico-religiosos do medicamento, construindo uma miscelânea que corrobora mais uma vez a leitura de que o erudito e o popular caminham lado a lado em tais livros herméticos, sendo o dignatário aquele que cura em nome do sagrado, auxiliar da proteção divina pintada, no microcosmo de almanaque, pelo azul celeste do "néctar dos deuses", chamando a atenção dos leitores para o fato de o remédio apresentar poderes divinos como ele, pois está devidamente abençoado.

Assim, fé e ciência médica amalgamam-se na propaganda, uma certifica a outra, o que reforça a atmosfera místico-poética dos almanaques, que assegura os leitores no microcosmo divinizado e resguardado das mazelas da vida. É nessa perspectiva que é importante considerar o que Citelli analisa sobre as técnicas de persuasão na propaganda ou na publicidade, quando alguns esquemas básicos são usados para convencer os receptores. Das cinco técnicas que este aponta, destaca-se a que justifica a escolha do sacerdote como meio de persuadir os leitores, o Apelo à autoridade. Nessa, observa-se a presença de alguém que legitima o que está sendo afirmado, como citações de especialistas em determinadas dissertações, o hábito que a publicidade tem de utilizar o dentista, o médico, o atleta, com o intuito de tornar "mais real" a mensagem ${ }^{87}$. É o que se nota com a figura do sacerdote, autoridade eclesiástica que autentica a seriedade e a eficácia do remédio, como se garantisse tanto o seu poder médico-científico, quanto o seu poder sagrado.

É a Paidéia Poética quem prescreve tal ambrosia, sendo o licor Bénédictine um medicamento que está simbolicamente em consonância com a atmosfera mística do Almanach Hachette, tendo, na dieta quimérica, o alimento curativo e nutritivo tanto para o corpo como para o espírito, a fim de habilitar os leitores para alcançar o Sublime, inscrito na cidade excelente, do melhor dos mundos possíveis.

Seguindo o mesmo viés místico-poético do almanaque francês, tem-se outro medicamento que nutre o corpo e os sonhos dos leitores, o elixir vinoso Quina-Laroche do Almanaque Brasileiro Garnier para o ano de 1907. Neste encontramos o vinho e a quina que segundo Aurélio (2000, p. 545) é "S. f. Bras. 1. Arvoreta rubiácea (Cinchona Ledgeriana), originária do Peru e notável por suas propriedades antitérmicas. 2. Designação comum a

87 . Ver Linguagem e Persuasão de Adilson Citelli (1991, p.460), em que aborda a partir da obra Técnicas de Persuasão de J. A. C. Brown esquemas básicos para convencimento dos receptores. ${ }^{\natural}$ 
numerosas plantas nativas cuja casca amarga e sem motivo, reputada ativa contra febres e malária, por comparação à quina (1). 3. P. ext. A casca da quina (1 e 2)". A representação de cunho simbólico, por se tratar de um elixir, direciona para a história do vinho, bebida ora sagrada ora profana, que segundo Guarinello teve ao longo do processo de civilização papel de agente civilizador. Dessa maneira, criou-se uma "civilização do vinho", posto que tal bebida operou de forma decisiva no interior das diferentes culturas que se desenvolveram às margens do Mediterrâneo antigo. O autor ainda chama a atenção para um ditado alemão que o homem é aquilo que come (Mann ist was man isst), o que sustenta a tese de que o vinho tenha sido mais que uma bebida, ou um alimento. $\mathrm{O}$ vinho era considerado pelos antigos como bebida divina, remédio poderoso, incluído em quase todas as receitas médicas, além de ser considerado como alimento essencial. Menciona que foi ainda instrumento de sociabilidade, manancial de prazeres, mas também de vício, representou status social, mas também sinônimo de degradação moral. Logo, o vinho para essas culturas foi extremamente importante, deixou sinais em todos os âmbitos da vida social ${ }^{88}$. É nesse viés que se analisa o elixir vinoso QuinaLaroche, pois este segue praticamente o mesmo princípio do vinho nas civilizações antigas, posto que também é visto como alimento, ou seja, tonifica o corpo, reconstitui-o, é eficaz no combate às febres e um bálsamo para o espírito: Tonico, Reconstituinte, Febrifugo.

Considerando a simbologia que os elixires apresentam ao longo da história, analisa-se o Quina-Laroche como medicamento que segue o mesmo preceito do vinho para os antigos, como bebida divina, o que remete ao poder que tal panaceia tem para curar todos os males, ou seja, um remédio milagroso que tem, além dos princípios ativos do vinho, todo o misticismo que circunda os elixires. Ora, o Quina-Laroche é mais que um tônico comum, visto tratar-se de um medicamento que apresenta os poderes tanto do vinho quanto dos elixires, sem falar no poder sagrado das plantas - "o extracto completo das 3 quinas" - segundo a história da medicina popular. Logo, há uma tripla simbologia na composição do Quina-Laroche, pois é vinho-elixir-planta, elementos constitutivos de sacralidade, haja vista o primeiro como oblação aos deuses, o subsequente como bebida deliciosa, confortadora e mágica, e o último como representação do poder sagrado da terra em consonância com o Cosmo que, por sua vez, está em harmonia com o microcosmo místico-poético do almanaque brasileiro.

88 . Ler artigo intitulado "O Vinho: uma droga mediterrânea" de Noberto Guarinello retirado da obra Drogas e Cultura: novas perspectivas (2008, p.193). 
Nesse sentido, o elixir vinoso aparece na propaganda como superior em detrimento dos demais, posto que o seu discurso apresenta-o como "de sabor agradavel e muito superior a todos os demais Vinhos e Xaropes de Quina", ou seja, a linguagem persuasiva do anúncio busca convencer os leitores do almanaque de que a superioridade do Quina-Laroche é notável. Por isso que é empregado "nos casos de Doenças do Estomago, Falta de Forças, Febres, etc", além de possuir duas fórmulas, o "Quina-Laroche Ferruginoso contra Anemia, Chlorose e nas Convalescenças" e o "Quina-Laroche Phosphato contra o Lympatismo, Escrofulas, Enfartes dos Ganglios, etc". 

Além da superioridade do elixir vinoso, é importante ressaltar a presença da díade sagrado-profano, como visto acima na propaganda do almanaque francês, o que leva a considerar simbolicamente o vinho presente no Quina-Laroche, ora como bebida divina, ainda segundo o Cristianismo como o sangue de Cristo, ora como bebida típica de rituais pagãos, que de acordo com Carneiro ${ }^{89}$ o paganismo greco-romano, religião olímpica do Estado, prevalecia sobre os cultos populares de êxtase e embriaguez dionisíaca, nos quais o consumo de drogas foi controlado moralmente assim como o sexo e a comida. É então, a conquista do prazer, da alegria e da terapêutica espiritual do indivíduo, características das festas dionisíacas, que o elixir vinoso simbolicamente representa, posto que o vinho do Quina-Laroche remete a uma embriaguez fortalecedora, realizadora e prazerosa, que ajuda os leitores do Almanaque Brasileiro Garnier a pelejar contra as intempéries cotidianas da vida, para então, aptos pela cura sacralizada de tal medicamento, poderem habitar a polis harmônica engendrada no Sublime do melhor dos mundos possíveis.

É importante salientar, por meio de mais um exemplo, que a cultura francesa sobeja no almanaque brasileiro, posto que tal medicamento é francês e pode ser adquirido em Paris, número 20, Rue des Fossés-Saint-Jacques, e em todas as boas Pharmacias e Drogarias, o que explicita os ares franceses que os cidadãos respiravam na chamada Belle Époque carioca, posto que até mesmo a anemia ou a tristeza eram combatidas com o tônico comercializado, pela ponte quimérica entre as cidades ideais, que proporcionava simbolicamente uma embriaguez poética e requintada.

O elixir vinoso Quina-Laroche é um medicamento que reforça o microcosmo místicopoético do almanaque brasileiro, seja pela segurança da linguagem persuasiva que o coloca como salvação para as enfermidades, seja pelo seu caráter alcoólico-tonificante que assegura simbolicamente o prazer e a ventura para curar os males da vida moderna e habilitar os leitores para o alcance do Sublime na polis harmônica.

Se nos Campos Elíseos as almas virtuosas desfrutavam de toda sorte de regozijo e os culpados, distribuídos pelos compartimentos do Hades, viviam sob a sentença da dor e das lamentações, nos almanaques os leitores são curados de suas fraquezas morais e físicas para adentrarem no próprio Céu de Brigadeiro, ou melhor, de ambrosia, calçado, nas páginas de

89

. Carneiro, p. 18. 
tais livros herméticos, com o verde, da relva sempre verdejante, oriundo da propaganda, para então, deleitarem-se com os manjares feitos de almanaquias que permitem sonhar.

É na simbologia do sagrado tanto do microcosmo místico-poético de almanaque, quanto de seus medicamentos, que se dá a feitura das cidades ideais, a cada ano, como uma nova Criação, a volta ao in illo tempore, onde já não existe Céu e Inferno. Tal divisão é suprimida por conta do divino descer ao chão de almanaque para curar os males da modernidade, o que simboliza a terapêutica dos médicos-sacerdotes colaboradores do criador, o flâneur-poeta que, por sua vez, pela Paidéia Poética, educa os leitores para flanar pelo mercado onírico produtor de boa ventura, a fim de adquirir as almanaquias condutoras do Sublime nas cidades excelentes, Paris e Rio de Janeiro, do melhor dos mundos possíveis.

\section{Fetichização de almanaquias: mercadorias de um microcosmo onírico}

Tendo em vista a análise das diferentes formas de proteção do sagrado nos almananaques, das quais o poder de auspiciar boa ventura contribui para a edificação das cidades utópicas, Paris e Rio de Janeiro, e para a oferta de um destino repleto de regozijo, por meio da lisibilidade dos signos carregados de poeticidade e de consolo para os males da modernidade, que se assinala mais uma tópica sustentadora de tal atmosfera feérica, a desmedida oferta de mercadorias-almanaquias para deleite e para delato, pelo microcosmo quimérico, da realidade fetichizada moderna.

Para tanto, considera-se o viés quimérico das urbes perfeitas que garante aos leitores a salvação das problemáticas cotidianas, como uma espécie de estabelecimento das polis onde a boaventura e a tessitura poética incansável, do tecelão de sonhos, são os ingredientes que permitem o alcance do Sublime. É, nessa perspectiva, que o flâneur-poeta apresenta uma série de almanaquias carregadas de poeticidade para cura das inquietações dos leitores da modernidade, sendo a fetichização das inúmeras mercadorias, no microcosmo de almanaque, o caminho para denunciar o mundo das fantasmagorias da cultura industrial, travestindo-as de uma roupagem de equidade, de gozo e de abundância nas polis excelentes que, por sua vez, representam simbolicamente a recuperação da própria idade de ouro, descrita por Hesíodo, pela Criação anual, o tempo em que os homens viviam longe dos infortúnios e preocupações, alegravam-se em festins e nem mesmo o temor da finitude assombrava-lhes, pois morriam como que por sono tomados, além de usufruírem de todos os bens, visto que a terra nutriz, de 
maneira espontânea, dava-lhes o fruto abundante e generoso, e ali viviam contentes, tranqüilos e nutrindo-se de seus fartos $\operatorname{proveitos}^{90}$.

É, pois, no ato de poetizar as cidades, mesclado ao hermetismo dos almanaques, que os leitores encontram resposta para as indagações de qualquer natureza, tendo na transformação terapêutica do fetiche, como objeto a que se atribui poder sobrenatural e a que se presta culto, em cura do mal utilitarista que acomete a modernidade, mais um ingrediente para sanar as dores da existência, sejam elas físicas ou espirituais, a fim de alcançar o Sublime nas cidades excelentes. O bálsamo curativo da falaz ordenação moderna, oferecido pelo mercador de ilusões, traduzido pelas almanaquias deleitosas, remete ao que Benjamin no livro das passagens, rememorando Marx, menciona sobre o caráter fantasmagórico das mercadorias:

(...) Les choses se sont émancipées et adoptent um comportement humain... La marchandise s'est transformée en idole qui, bien qu'elle soit le produit de la main de l'homme, commande à ce dernier. Marx parle du caractere fétiche de la marchandise. "Ce caractère fétiche du monde des marchandises provient du caractère social spécifique du travail qui produit des marchandises... C'est seulement un rapport social determine des hommes entre eux qui revêt ici pour eux la forme fantasmagorique d'un rapport des choses entre elles ... (BENJAMIN, 1989, p. 201)

É no viés do comércio de boa ventura para lisibilidade do cunho mercadológico circundante, que se analisam algumas mercadorias dos almanaques, representativas de uma fetichização poética que alimenta o imaginário dos leitores e os liberta dos grilhões que os impedem de conhecer a Verdade, sendo o flâneur-poeta, o responsável, ao tornar as cidades lisíveis e comercializar os produtos para deleite, o áugure provedor de um destino repleto de delícias por meio da tessitura do Divino.

Nessa perspectiva, inicia-se com a análise da Casa Colombo do Almanaque Brasileiro Garnier para o ano de 1908, comércio cuja divisa, desde sua fundação, garante aos leitores se tratar da melhor casa dentre as outras: "Vender Bom e Barato, Para Vender Muito". Representativa dos grandes magazines da modernidade, que já Émile Zola nomeava "Catedrais do luxo", está sitiada no endereço de requinte, - que segundo Needell (1993, p. 191), "a comunidade de comerciantes franceses deitou raízes, desbancando o comércio inglês de produtos ordinários, e coexistindo com os portugueses.”, - a Rua do Ouvidor. É em tal logradouro de requinte e também à Avenida Central que a Casa Colombo assume uma espécie

90 . Para melhor compreensão da idade de ouro hesiódica, ler As cinco raças da obra $O s$ Tarabalhadores e os dias de Hesíodo, São Paulo: Iluminuras, 2002, pp. 29, versos 110 a 120. 
de comércio de prazeres, cuja credibilidade dá-se na garantia do vender de qualidade sem onerar os clientes, com o intuito de vender muito. É nesse jogo de mercado/prazer que se observa o caráter fetichista do magazine, posto que em seus armazéns, os leitores podem encontrar tudo de que necessitam, desde Artigos para Homens, Senhoras, Meninos e Meninas, até sua transformação em culto de mercadorias que têm poder mágico para obliterar as problemáticas circundantes. Ora, a denúncia de tal realidade mercadológica, transformada pela Poiésis, a cada nova Criação de almanaque, para recuperação do Sublime, provoca a cura dos temores modernos - o receio concernente à inexorabilidade do tempo, por conseguinte, à finitude do ser, a sua origem, às moléstias, aos acidentes, aos diversos problemas sociais, às guerras vindouras, dentre outros - pela volta ao in illo tempore, a fetichização convertida em conhecimento dos males que encobrem a verdadeira Beleza do mundo, sendo a leitura diária de tais livros místico-poéticos e a oferta de um outro comércio, o das almanaquias reveladoras do Belo, a chave para adentrar nas cidades ideais.

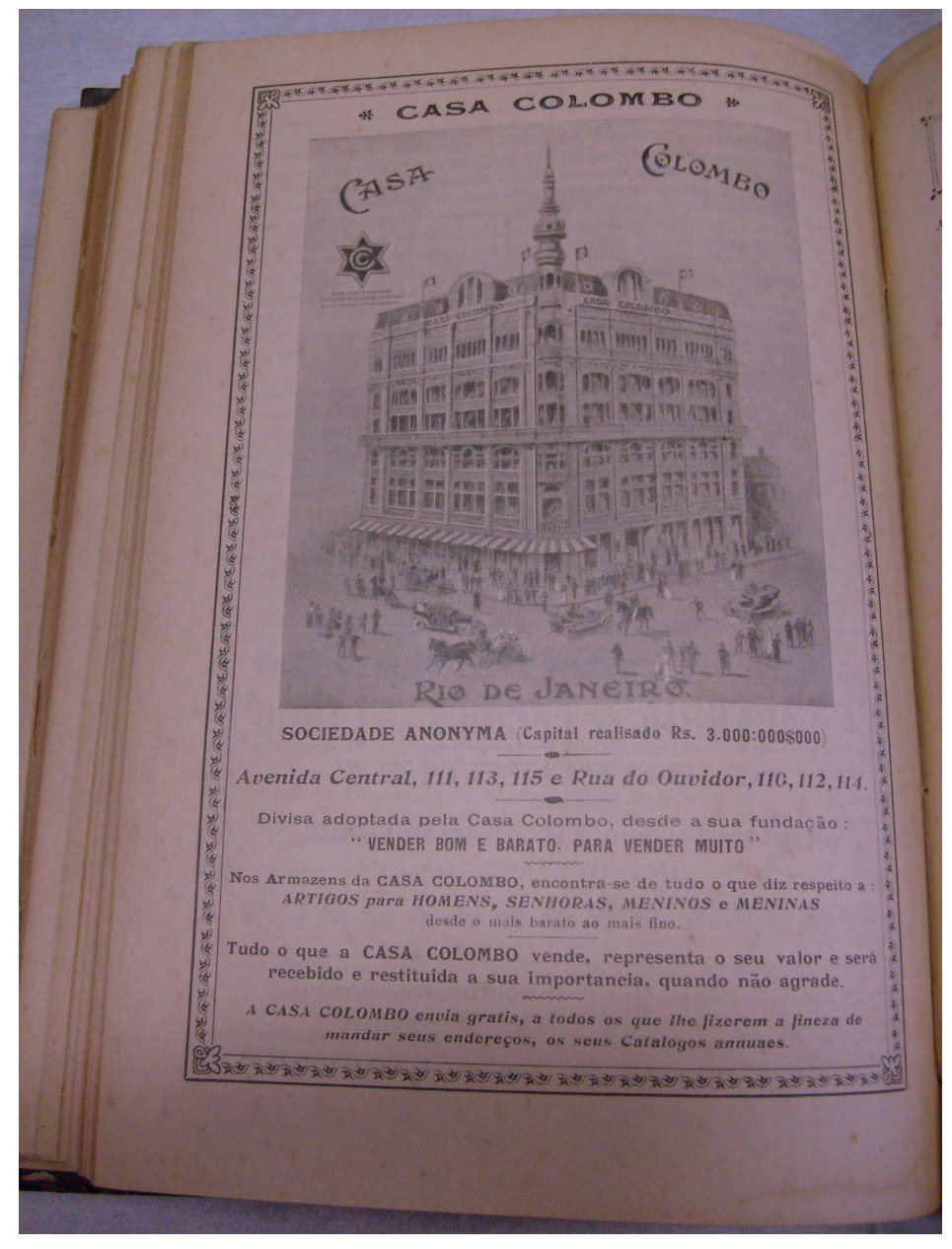


Mediante tal oferta de felicidade na volta à idade sem males, observa-se ainda que os artigos são comercializados com garantia de acessibilidade a todas as classes, pois vão desde os mais finos, até os mais baratos, ou seja, tal fetichismo moderno é assegurado tanto aos pobres, quanto aos ricos, equidade existente, verdadeiramente, apenas na cidade excelente, em que as discrepâncias de ordem social são inteiramente suprimidas. É na aquisição de tais mercadorias que os leitores têm reconhecimento social, levando novamente às incursões benjaminianas, quando cita o fato dos grandes magazines serem os responsáveis pelo sentimento de existência dos consumidores:

Avec la création des grands magasins, pour la première fois dans l'histoire, les consommateurs commencent à avoir le sentiment d'exister en tant que masse. (Seule La disette, auparavant, leur donnait). Cela accroît considérablement la part des circenses et l'élement théâtral dans le commerce [A4,1]. (BENJAMIN, 1989, p.73)

É, pois, nessa relação feérica em que a mercadoria tem poder para fornecer o sentimento de existência aos consumidores, fazendo com que sua aparência seja percebida a partir do objeto possuído, que se verifica o processo de coisificação ou reificação (do latim res, coisa) decorrente da prática consumista na modernidade. Em virtude da reificação das relações sociais, observa-se um jogo de compensação das angústias humanas na fantasmagoria do consumismo, posto que o valor das mercadorias da Casa Colombo aparece como uma espécie de naturalização do social, sendo agora os próprios artigos, bens relacionados entre si, responsáveis pelo bem-estar dos clientes, tendo na restituição, a garantia de que realmente os produtos têm qualidade/poder: "Tudo o que a Casa Colombo vende representa o seu valor, e sera recebido e restituida a sua importancia, quando não agrade".

A abertura como sinônimo da saída da caverna da fetichização moderna, pela Paidéia Poética, denunciadora da coisificação das relações sociais, permite aos leitores/consumidores um novo caminho terapêutico para os males da modernidade, transformando a suntuosidade do prédio da propaganda e a participação do mundo utilitarista, situado à Rua do Ouvidor e à Rua Central, em endereço da fábrica de sonhos, ou notadamente, da felicidade inscrita no grande mercado do Sublime de almanaque. Como lisibilidade da cidade moderna, observa-se que a mercadorias portadoras de prazer e de identificação podem ainda ser enviadas por correio aos leitores, caso tenham a gentileza de enviar seus endereços, recebendo, em decorrência, catálogos anuais repletos de mercadorias para deleite: "A Casa Colombo envia gratis, a todos os que lhes fizerem a fineza de mandar seus endereços, os seus Catalogos annuaes." 
É nos transeuntes e transportes apressados do anúncio que a propaganda reforça seu caráter mercadológico, tendo na multidão de consumidores que parecem entrar e sair do comércio, a constatação de que o Rio de Janeiro como um todo já certifica a credibilidade de tal estabelecimento, representando a urbe como lugar de progresso e de ventura, característico da chamada Belle Époque carioca, predicado que, no entanto, é realmente alcançado na cura dos males modernos, que impedem os leitores de alcançar a Verdade, a cada nova Criação de almanaque.

O mesmo ocorre em um anúncio da Grande Rubanerie de St-Étienne (Loire), do Almanach Hachette para o ano de 1907, contudo, o grande magazine situa-se em St-Étienne, mas é responsável pela manutenção do sonho de consumo dos parisienses e da cidade que recebe sempre o que há de novo/bom e belo do Pays de Cocagne.

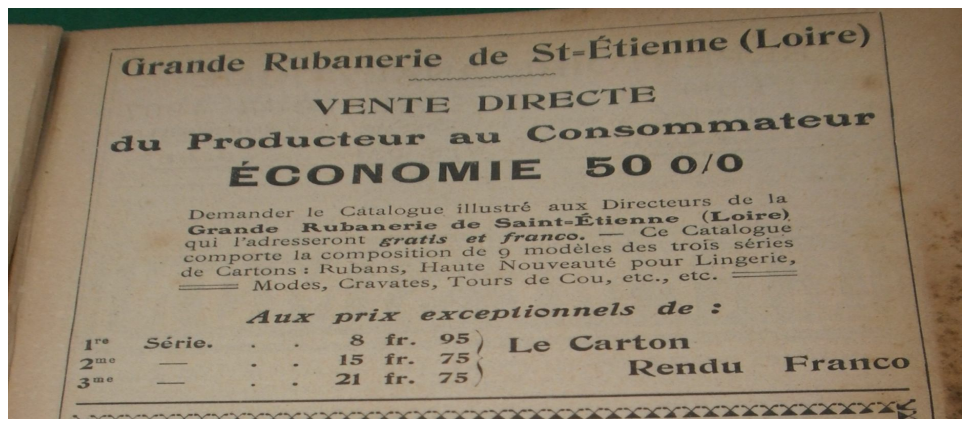

É na cidade ideal, Paris, traduzida aqui pela tão sonhada conquista do Pays de Cocagne, que se retoma a definição de Thierry Paquot sobre tal empíreo na Terra, cuja etimologia ainda é misteriosa, em francês, o termo surge do provençal, em que "cocagne" significa "pastel de nata" e simboliza a prosperidade. É nessa relação entre St-Étienne-ParisPays de Cocagne, que se observa a promessa de um idílio na Terra, sendo o flâneur-poeta, ao flanar pela cidade, o responsável pela lisibilidade e estetização que permite sonhar com um mundo repleto de delícias. A conquista da cidade utópica, componente do Pays de Cocagne que, por sua vez, está inserido na Terra sem Males, dá-se no microcosmo místico-poético dos almanaques, onde os leitores franceses, parisienses e oriundos de St-Étienne (Loire), estão a salvo das intempéries da modernidade, tendo na fetichização das mercadorias, traduzida em almanaquias deleitáveis para alcance do Sublime, mais um ingrediente que reforça a sua atmosfera quimérica.

$\mathrm{O}$ acesso dos leitores às mercadorias que permitem sonhar ocorre na venda direta do produtor ao consumidor da Grande Rubanerie, com garantia de economia de 50\%: "Vente Directe Du Producteur au Consommateur, Économie 50\%”, o que reitera a lógica 
mercadológica da sociedade moderna ao satisfazer as pulsões dos leitores com o poder mágico e benéfico assegurado pela fantasmagoria do consumo. Para tanto, os leitores/clientes devem fazer o pedido do catálogo, ilustrado e farto de artigos que alimentam suas veleidades, aos diretores do estabelecimento que lhes enviam gratuitamente e sem taxas de transporte: "Demander le Catalogue illustré aux Directeurs de la Grande Rubanerie de Saint-Étienne (Loire) qui l'adresseront gratis et franco". Esse fichário de prazeres comporta nove modelos de três séries de encartes, com artigos diversos que remetem ao fetichismo criado pelo poder que se atribui a tais objetos: "Ce Catalogue comporte la composition de 9 modèles des trois Cartons: Rubans, Haute Nouveauté pour Lingerie, Modes, Cravates, Tours De Cou, etc., etc".

Oferta que direciona novamente à transformação das relações humanas em relação entre coisas, havendo um processo de reificação do homem até o ponto de ser substituído ou identificado pelo valor daquilo que adquire, remetendo a uma citação benjaminiana:

C'est seulement sous forme de marchandise que la chose exerce son influence aliénante sur les hommes qu'elle rend étrangers les uns aux autres. Cette influence, elle l'exerce par son prix. L'identification à la valeur d'échange de la marchandise, avec sont substrat égalisant, voilà l'élément decisif. L'égalité qualitative absolue du temps dans lequel se déroule le travail qui produit la valeur d'échange, est le fond grisâtre d'où se détachent les couleurs criardes de la sensation. (BENJAMIN, 1989, p.404)

É nessa identificação com o valor de compra, denunciada pela poética de almanaque, que se observam os valores mercadológicos adotados pela sociedade moderna, havendo na alienação a obliteração do entorno significativo para a produção de bens de consumo, como a exploração da força de trabalho com a unívoca finalidade, a acumulação de capital. Dessa fetichização, os leitores são orientados, pela Paidéia Poética, a tirar o véu que encobre o ingrediente mágico-alienante de tais mercadorias, para então, serem curados da cegueira que os impedem de conhecer a Verdade, sarando os dissabores cotidianos com produtos comercializados no grande mercado revelador da ignorância moderna, sejam elixires que prolongam a vida, sejam destinos protegidos por astros, santos e progosticadores, ou a cura para males da existência, transformando, pela Criação anual, tal realidade nefasta, em sítio místico-poético onde as mazelas de qualquer natureza são suprimidas. Como no almanaque brasileiro, em decorrência da comercialização da felicidade, observa-se que os preços para sua aquisição são indicados como extraordinários, ou seja, singulares em se tratando da concorrência, sendo "a primeira série 8 francos, a segunda 15 francos e a terceira 21 francos", além de uma espécie de brinde, o encarte recebido sem taxas adicionais. 
Diante do processo de coisificação do homem, ainda se ressalta a relevância da relação comercial entre a província e a capital, sendo a primeira identificada com o valor de suas mercadorias e a segunda também ao adquiri-los, ou seja, a dinâmica para o acúmulo de capital traduz o progresso tanto da vida metropolitana quanto da vida provinciana. Ora, a relação entre as mercadorias dá-se agora na relação entre o comércio fetichizado das cidades, fazendo do componente feérico que as acompanha, a salvação para as mazelas humanas.

É na transformação dos almanaques em um grande mercado poético, utilizando-se do onírico para delatar o falso molde da matéria caótica moderna, que o flâneur-poeta permite a lisibilidade das urbes na modernidade, sendo este observador e contemplador dos signos sociais, um negociante de mercadorias provenientes de um comércio tecedor da verdadeira beleza do mundo. Logo, a oferta das polis perfeitas é decorrência de uma embriaguez causada pelo teor poético das negociações, sendo o ópio de almanaquias o responsável pela construção dos paraísos artificiais, onde o sonho é o ingrediente terapêutico das inquietações existenciais, pela feitura anual de almanaque, para conquista do Sublime. É, pois, no movimento de transformação das cidades modernas, Paris e Rio de Janeiro, em mito de progresso e de consagração da consciência de trabalho, cujo culto à mercadoria é prática recorrente, que se considera a menção benjaminiana sobre a figura do flâneur:

Fondamentalement, l'identification à la marchandise est une identification à la valeur d'échange. Le flâneur est le virtuose de cette identification. Il emmène en promenade le concept même de vénalité. De même que le grand magasin est son dernier tapin, l'homme sandwich est sa dernière incarnation. (BENJAMIN, 1989, p.466)

Tal identificação com a mercadoria pelo flâneur é lisível nos almanaques, mas estetizada por meio de uma relação um tanto quanto simbólica, posto que o valor de compra é negociado entre o poeta, mercador de ventura, e os clientes/leitores, sendo o mercado central, tais livros herméticos, representado por grandes magazines e produtos de diversas lojas, a própria denúncia do fazer existir na fetichização comercial, a fim de cultivá-los para a Verdade. Ora, é nesse processo de coisificação do homem que o flâneur-poeta transforma a economia de mercado em economia de prazeres, havendo uma mais valia às avessas, em que a fonte de lucro não remunerada é convertida em elemento mágico para curar as perturbações do ser, inscrevendo na poeticidade das cidades excelentes, a salvação dos leitores dos males da modernidade. É, então, a partir do espetáculo poético, proveniente de uma contemplação visionária, que o flâneur-poeta - com seu estilo metafísico e místico em consonância com os almanaques - sana os desassossegos da natureza humana pela Criação anual, como recuperação da idade de ouro sem infortúnios de nenhuma natureza. Logo, o caráter fetichista 
das inúmeras mercadorias do mundo moderno é transformado, nos almanaques, em cultivo para o Belo, contribuindo para a manutenção e edificação das cidades utópicas, pela Paidéia Poética, do mercante de quimeras, como caminho para a edificação dos idílios terrestres, cuja mística simbólica possibilita a realização dos anseios dos leitores e a salvação dos males da vida, por meio do alcance do Sublime, no melhor dos mundos possíveis.

A poética que salva os leitores dos males da modernidade é ainda observada na mimesis das propagandas que permitem a lisibilidade das urbes modernas, a Loterias da Capital Federal do Almanaque Brasileiro Garnier para o ano de 1912 e a Loterie de L'Orphelinat National des Chemins de Fer do Almanach Hachette para o ano de 1907, que representam a supervalorização do dinheiro no mundo capitalista circundante, como ato denunciativo para cultivo dos leitores, pela Poiésis, na verdade traduzida em abundância e ventura para todos os habitantes do microcosmo excelente.

A promessa das polis utópicas, Paris e Rio de Janeiro, construídas sob a égide da abastança e do regozijo, é garantida por meio da poética ofertada pelo mercador de fortuna, cuja propaganda do almanaque brasileiro permite a sustentação desse universo onde se tem tudo, reiterando o supracitado Pays de Cocagne e, ainda, acrescentando o Mito do Eldorado e o de São Saruê. Sendo neste último, cuja simbólica calcada na religiosidade, salva os leitores da miséria da seca nordestina, mencionado no capítulo inicial, além do Mito do Eldorado, apresentado também na primeira tópica - constituindo uma antiga lenda, narrada pelos índios no período da colonização das Américas, que relata a construção de uma cidade suntuosa em que o ouro e os tesouros imensuráveis são a sua base - que se considera o viés mítico-poético das cidades excelentes como representação do próprio imaginário coletivo do povo francês e do povo brasileiro, o que é lisivel na fartura proveniente da terra fértil, sem males, da nova Criação, ora traduzindo a supressão dos males modernos, ora a seca ou o inverno rigoroso que provocam a escassez do alimento.

Considerando o microcosmo quimérico dos almanaques, repleto de um hermetismo cósmico-poético, em que a Criação anual dos almanaques protege seus leitores das 
problemáticas modernas, tem-se na presença simbólica dos mitos das cidades ideais, a salvação, pelo resgate onírico, dos deuses e dos heróis da epopeia antiga que também era tecida tradicionalmente no período de um ano, travestidos de entes virtuosos da época em questão, de santos, de signos, de homens dotados de poderes sobrenaturais e de outras práticas do universo do sagrado. Nesse sítio maravilhoso ou cidade poética das idéias, no melhor dos mundos possíveis, a beleza dá-se por meio da abertura ou da permissão do sonhar, fazendo do ouro em pó que o imperador passava em seu corpo para ficar com a pele dourada, segundo a lenda supracitada, a simbólica da riqueza ofertada aos leitores dos almanaques, traduzida na promessa de fortuna das Loterias da Capital Federal. É, pois, na poeticidade que nutre e garante fortuna, com quantias mágicas, que se nota uma sequência feérica inscrita nas "Extracções públicas sob a fiscalização do Governo Federal", cujos "Premios de 15:000 \$, 20:000 \$, 25:000 \$, 30:000 \$, 40:000 \$ e Aos Sabbados 50:000 \$, 100:000 \$, 200:000 \$”, ofertam, aos leitores, o sonho de almanaquias geradoras de uma vida afortunada.

As somas de bem-aventurança ainda são fornecidas pela Loteria de São João, com três sorteios, a ver: “100:000 \$, 100:000 \$, 200:000 \$”, o que nutre o imaginário dos leitores com uma mística de encantamento por meio do divino representado pelo santo, ou seja, a poética que faz gracejos com a díade sagrado/profano dos jogos de azar elevada à magia que permite o acesso ao Absoluto, possibilita a aquisição de um mundo repleto de delícias, que remete a uma citação de Alfredo Bosi de sua obra O Ser e o Tempo da Poesia:

É instrutivo ler as cartas de Mallarmé aos jovens simbolistas que rodeavam. Quando nelas se fala em ritmos livres, tem-se em pauta um modo singular, subjetivo, quase inefável, de atingir essências. Fala-se em "mistérios", em "magia", em "mística", em "encantamento". Retoma-se e rarefaz-se a expressão de Baudelaire: "a exigência devastadora do Absoluto". O absoluto é a gênese e a mira do texto. O poeta do "Lance de Dados", ciente que a sua mística de papel esvaziaria o divino, põe no lugar do Absoluto o Nada. (BOSI, 1977, p. $81-82$ )

É desse modo que o mapa do tesouro é fornecido aos leitores, fazendo do cunho místico dos almanaques, mesclado à tessitura poética das cidades, o alcance do Divino pelo ato criador a cada edição de almanaque, suprimindo, dessa maneira, os males da modernidade na medida em que os poetiza. Essa poética de almanaque que alimenta os leitores, como em um Banquete de deleites, garante a Sorte de adentrar nas cidades afortunadas, pelo desvelamento de uma política capitalista, de fetichização de mercadorias, para engendramento de urbes em que a abundância do ouro em pó transforma-se em metáfora da Beleza do mundo. Nessa perspectiva que se observa o caráter hermético da loteria em consonância com o 
microcosmo místico do almanaque, posto que o binário divino-mercadológico direciona a recusa da poesia à fetichização do mundo das mercadorias, visto que ainda que se encontrem produtos do universo capitalista, estes são mais um bálsamo denuciatório e curativo, pelo onirismo inscrito na nova Criação, das inquietações da existência e dos enganos do mundo sensível, fazendo da oferta de ventura, um brincar com a sorte, a Fortuna que salva os leitores do "tédio e do cinza" da modernidade:

Como descrever o regime de luta poética entre o mundo-da-vida e os modos de ser dos sistemas dominantes (capitalismo, tecnocracia, burocracia, indústria cultural)? Talvez me ajude uma expressão paradoxal: esse regime é de alucinação lúcida. A raiz comum aos termos da expressão é: luz. Alucinação. Abre-se, primeiro, o tempo iluminado até o delírio e a febre do encantamento de que os seres são penetrados quando os contempla o olhar de fogo do poeta. Os nomes são imagens, estas são ícones, objetos sacralizados. Há um fascínio pela figura do mundo, um fascínio de origem mágica, que dá ao nome do ser uma aura de motivação arcana e medusante, difícil de separar da idolatria. Nomen, numen. A poesia, corrente de "alumbramentos", para lembrar a cofissão de Manuel Bandeira, desloca-se de um fundo sem fundo da memória ou do inconsciente. $\mathrm{O}$ poema aparece em nossa cultura atulhada de empecilhos como um ato de presença puro, forte, arroubado, premente. Na poesia cumpre-se o presente sem margens do tempo, tal como sentia Santo Agostinho: presente do passado, presente do futuro e presente de presente. A poesia dá voz à existência simultânea, aos tempos do Tempo, que ela invoca, evoca, provoca. (BOSI, 1977, p.119-121)

Retomando a expressão brincar com a sorte para com os jogos que travestem a penúria com uma roupagem de suntuosidade, espécie de riso das tantas pirélhias e anedotas de almanaque denunciatórias dos males modernos, atualização do Ridendo castigat mores (rindo se criticam os costumes) e cultivo das virtudes, que o flâneur-poeta, por meio da tessitura poética, permite a lisibilidade das cidades enfermas, com um olhar visionário em consonância com o Cosmo, lendo no movimento dos astros, no mundo do Absoluto, a salvação poética do tédio já mencionado por Baudelaire ou da reificação das relações sociais. Ora, a poesia, "corrente de alumbramentos", reiterando Manuel Bandeira, permite que a poética de almanaque, lute contra "os modos de ser dos sitemas dominantes", fazendo de tal livro hermético, com seu caráter de recusa à compartimentação dos saberes inscrito sob a égide da misticidade, a salvação dos males da vida moderna. Logo, o almanaque, sendo metáfora de um grande poema, ou epopéia mágica, tecida no encadeamento encantatório de suas seções, permite que o tempo, temática cara a tal gênero popular, produza a simultaneidade temporal, buscando no passado a magia mítica, no presente o aprizionamento 
de sua inexorabilidade em seus vários calendários e em suas receitas de longevidade, e no futuro a leitura visionária que produz um presente e um porvir repletos de regozijo.

Essa poética que possibilita a lisibilidade das urbes na modernidade, tendo como ferramenta a utopia que garante um microcosmo abastado e deleitoso, é reforçada ainda no último jogo da propaganda, a Loteria de Natal, cuja soma é a mais vultuosa, "Prêmio Maior: 1:000:000:000 \$, assegurando os leitores de que haverá abundância nas festividades de fim de ano. Diante da promessa de abastança, o ouro em pó da cidade afortunada, Eldorado, é adquirido por meio de um billhete da Loteria da Capital Federal, garantindo à grande festa cristã, Natal, o Banquete e a ventura que sustentam as veleidades e os sonhos jamais realizados, tendo novamente na díade sagrado/profano, representação do brincar com uma espécie de sorte hermética - haja vista que o jogo anterior é dedicado ao santo São João e o último à simbologia da data que comemora o nascimento do Messias - a salvação das mazelas da modernidade. É essa poesia em consonância com o Cosmo, calcada em um misticismo que abriga das problemáticas existentes, seja ele dos santos, dos signos, dos mitos ou dos prognosticadores, que faz das polis ideais o lugar onde a magia é o elemento que produz a poeticidade tecedora da verdadeira Beleza do mundo.

Logo, ao flanar por tais cidades utópicas, os leitores têm por meio de sua tessitura poética, endereço certo para aquisição dos bilhetes que permitem o alcance de uma vida abastada e ditosa, à Rua do Ouvidor, n. 14, sendo ainda garantida a quimera da abastança aos leitores da província, cujos "Pedidos de bilhetes do interior devem ser dirigidos aos agentes geraes Nazareth e Cia.”, alimentando a promessa de que não apenas as urbes ideais são contempladas com tal oferta de ventura, mas todos que adentrarem no microcosmo onírico que permite sonhar com o melhor dos mundos possíveis.

O mesmo ocorre na propaganda do Almanach Hachette para o ano de 1907, cuja oferta de abastança advém das tintas poético-utópicas da estetização do mundo moderno, pela Loterie de l'Orphelinat National des chemins de fer . É na urbe ideal, Paris dos sonhos, que os leitores podem adquirir fortuna ao flanar pelas ruas de "ouro em pó", onde a vida afortunada pode ser comprada com um simples bilhete da sorte, tendo na divisa do ajudar o próximo, a construção virtuosa do lugar em que a justiça é o elemento fundamental para se viver bem, a República das delícias, sendo os órfãos e as viúvas amparados por tal jogo que simboliza a virtude da benevolência em consonância com a oferta de ventura, Pour les Veuves et les Orphelins des Employés des Chemins de Fer Français. Ora, a tessitura poética de tal cidade utópica é realizada por meio de receitas quiméricas, tendo no desenvolvimento das 
virtudes de seus cidadãos, o ingrediente primordial para a edificação de um microcosmo sem males.

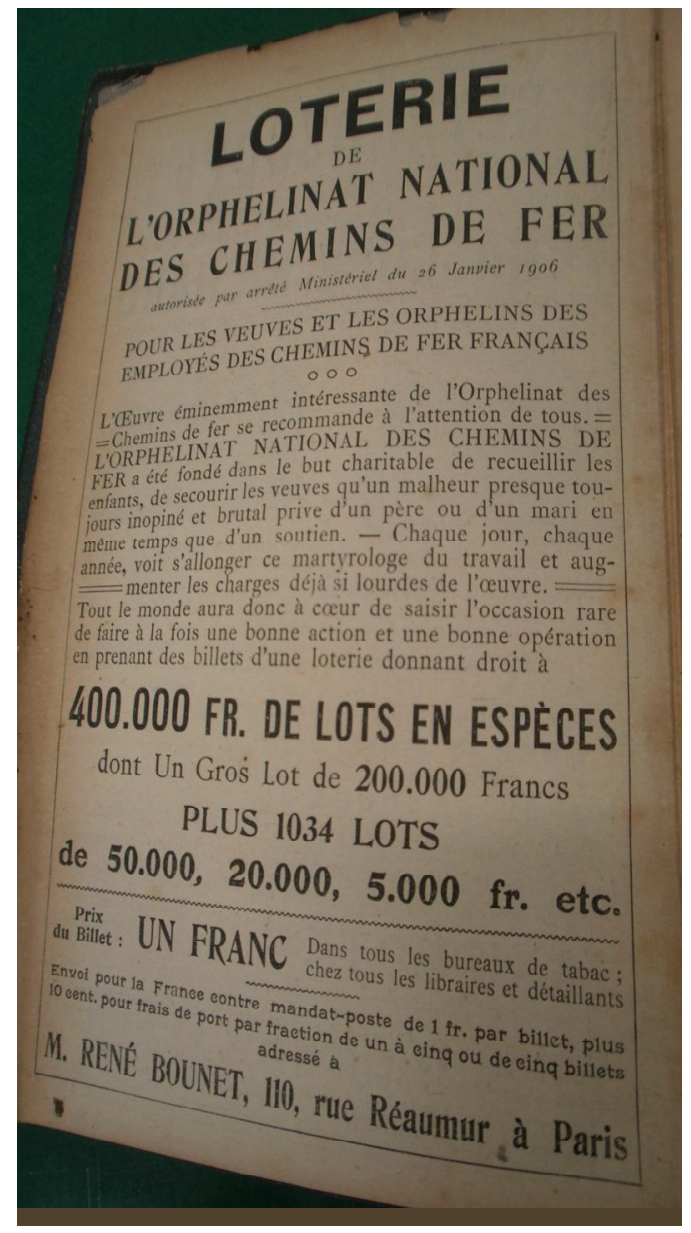

Como nas Loterias da Capital Federal do almanaque brasileiro, também se observa que a fortuna é garantida por um viés hermético, visto que o fato de fazer uma boa ação nutre o espírito com o alimento que aproxima do Divino, a compaixão, uma das virtudes almejadas para a edificação da cidade ideal, além do montante de 400.000 FR, o que faz novamente do brincar com o sagrado/profano, do jogo de azar embuído de uma aura místico-poética no microcosmo de almanaque, a salvação das problemáticas da modernidade, dentre elas, as inúmeras greves características das discrepâncias sociais na Belle Époque, que segundo Winok, na III República, crescem de maneira acentuada até mesmo em detrimento do desenvolvimento industrial; o que é elucidado pelas 890 greves em 1900, 1087 em 1904, 1354 
em 1906 e 1517 em 1910, cujas manifestações das duas últimas datações consideradas as mais numerosas e violentas ${ }^{91}$.

É na poética de almanaque que se dá a construção do microcosmo repleto de deleites, ausente de descontentamento de nenhuma ordem, posto que a equidade é a sua divisa, tendo na garantia da urbe afortunada e virtuosa, por conseguinte na utopia, o caminho que a Poiésis percorre para resistir aos ditames do mundo capitalista, o que remete a uma citação de Alfredo Bosi e à Iniciação Poética já mencionada no primo capítulo, como resgate do Belo perdido, em meio ao utilitarismo moderno, pela Criação anual:

A poesia resiste à falsa ordem, que é, a rigor barbárie e caos, "esta coleção de objetos de não amor" (Drummond). Resiste ao contínuo "harmonioso" pelo descontínuo gritante; resiste ao descontínuo gritante pelo contínuo harmonioso. Resiste aferrando-se à memória viva do passado; e resiste imaginando uma nova ordem que se recorta no horizonte da utopia. Quer refazendo zonas sagradas que o sistema profana (o mito, o rito, o sonho, a infância, Eros); quer desfazendo o sentido do presente em nome de uma libertação futura, o ser da poesia contradiz o ser dos discursos correntes. (Ainda que nem sempre possa impedir de todo que um outro pseudovalor formal vigente - e, daí, obliquamente ideológico venha a cruzar o seu jogo verbal). A luta é, às vezes, subterrânea, abafada, mas tende a subir à tona da consciência e a acirrar-se porque crescem a olhos vistos as garras do domínio. Em termos quantitativos, nunca foram tão achapantes o capital, a indústria do veneno e do supérfluo, a burocracia, o exército, a propaganda, os mil engenhos da concorrência e da persuasão. A ferida dói como nunca. Os seus lábios estão sempre abertos, não os fechará quem feche os olhos. (BOSI, 1977, p. 146)

É, pois, a poética de almanaque que salva os leitores da "falsa ordem", fazendo de sua harmonia mística com o Cosmo, a abertura para uma nova ordem, a do engendro anual, a da utopia que remete às "zonas sagradas" que o sistema invalida em nome da razão, da ciência e do capital, que há muito tempo, elimina o sonhar e a libertação para o verdadeiro conhecimento da Beleza do mundo. É nessa luta incessante que a Poiésis resgata, o que é notável nos almanaques, os mitos erradicados em nome da ratio, que nada mais é do que a busca por respostas frente à impotência das eternas inquietações humanas, eliminando o que de mais caro existe na humanidade, o sonhar que liberta dos grilhões dos sistemas falseamente ordenados. Assim, a poeticidade da nova ordem é construída por meio da utopia da cidade ideal, tendo na quimera o abrigo certeiro para os dissabores da modernidade. É nessa

$91 \quad$. Winok, p. 146. 
perspectiva que a propaganda é inscrita, tendo em seu discurso de abastança e de virtude, o sustento da ordem político-poética da urbe ideal, com a loteria que garante fortuna e, simultaneamente, equidade na cidade excelente. Desse modo, o anúncio reforça o discurso da beneficência ao expor o objetivo para o qual o orfanato foi edificado, único e exclusivamente para recolher crianças e viúvas, que porventura, tenham perdido o pai ou o esposo inesperadamente, realidade inexistente no melhor dos mundos possíveis, visto que a equidade entre os entes e o eterno renascimento de ventura, a cada feitura de almanaque, substituem a função caritativa de instituições que existem justamente para amenizar males que não podem ser extinguidos na modernidade: "L'Orphelinat National des Chemins de Fer a été fondé dans le but charitable de recueillir les enfants, de secourir les veuves q'un malheur presque toujours inopiné et brutal prive d'un père ou d'un mari en même temps que d'un soutien".

O discurso caritativo é ainda reiterado ao assinalar o fato de que cada vez mais o Orphelinat des Chemins de Fer necessita de mantenedores, visto que seus custos com encargos, já onerosos, aumentam rapidamente. É, dessa maneira, que o viés da virtuosidade é corroborado e estimulado, pela Poiésis, na cidade ideal, mas denunciatório da cultura capitalista, posto que se todos têm a rara ocasião de fazer, respectivamente, uma boa ação e uma boa operação ao adquirir os bilhetes da loteria, cujo prêmio é de 400.000 francos, pago em espécie por meio de uma divisão sugestiva que parece aumentar a soma representativa da vida afortunada, observa-se também que o benéfico está imbuído de vantagens, o que é característico da modernidade utilitarista: "Chaque jour, chaque année, voit s'allonger ce martyrologe du travail et augmenter les charges déjà si lourdes de l'oeuvre. Tout le monde aura donc à coeur de saisir l'occasion rare de faire à la fois une bonne action et une bonne opération en prenant des billets d'une loterie donnant droit à 400.000 FR de Lots en Espèces dont Un Gros Lot de 2000.000 Francs Plus 1034 Lots de 50.000, 20.000, 5.000, etc."

A oferta de uma vida virtuosa e abastada tem preço e endereço na urbe utópica, como na propaganda brasileira, 110, Rue Réaumur à Paris, um franco por cada bilhete, que pode ser adquirido em tabacarias, livrarias e pequenos comércios, também enviado para outras cidades da França, pela quantia de um franco por bilhete, direcionada à administração dos correios, mais dez centavos por encargos de transporte pela fração de um a cinco ou de cinco bilhetes, endereçado à M. René Bounet. Como no Almanaque Brasileiro Garnier, o sonho de uma vida afortunada e feliz não é restrito aos habitantes da cidade ideal, Paris, mas ofertado a todos do país dos cocagnes, pastéis de nata, cuja simbologia representa a prosperidade deste microcosmo de fartura e de onirismo. 
Em tal comércio de boa fortuna, tanto dos magazines, Casa Colombo e Grande Rubanerie de Saint-Étienne, representantes das grandes lojas de departamento do início do século XX, quanto dos jogos de loteria que garantem vida afortunada nas cidades excelentes, tem-se a recuperação da mascataria, como sinônimo de purificação das mercadorias modernas em almanaquias para sonhar, o que direciona à imagem dos colporteurs ou dos mascates que outrora tiravam de suas hôtte ou balaio as novidades que permitiam o reluzir dos olhos diante do novo. Ora, é na abertura de tais livros herméticos que a mascataria faz-se atualizada, na simbologia das tantas almanaquias que recheiam tais "balaios mágicos", como se os artigos para homens, senhoras, meninos e meninas, os laços, as novidades de lingerie e de moda, as gravatas, os lenços para pescoço, os bilhetes de loteria, reavessem a época de encantamento em que a venda de porta a porta estava resguardada do fetichismo moderno, mas portadora simbolicamente de uma espécie de desvelamento diante da falsa aparência, haja vista o acesso à literatura popular tanto francesa quanto brasileira que fomentava, a sua maneira, um tanto quanto encantatória, o cultivo dos entes e a sua imaginação.

É, pois, no comércio popular de almanaque, na mascatagem que possibilita acesso igualitário aos artigos dos magazines de prestígio que, no Brasil, - segundo Needell (1993, p.280) representava apenas $0,58 \%$ da população participante do mercado de luxo da Belle Époque carioca, - como a Notre Dame de Paris que só vendia importados caros para uma ínfima parte da população, no logradouro da elegância, também à Rua do Ouvidor, semelhante à Casa Colombo, no entanto a segunda caracterizada mais como loja de departamento comum na Paris da época, mas no mesmo sítio demarcador de uma clientela seleta, e na França, no endereço que comercializa mercadorias para vestimenta da população também nos moldes da chamada Belle Époque, de acordo com o requinte do período, mas direcionado a um determinado público tendo em vista a árdua realidade dos trabalhadores parisienses, dentre eles, retomando o estudo do doutor René Martial por Winok, o operário chapeleiro que ganhava entre 7, 50 e 10 francos por dia, dispendendo 3,60 francos para sua alimentação e 0,60 francos para o transporte, sendo o restante dispendido para alimentar, alojar e conservar sua família, além do carpinteiro que recebia somente 7 a 9 francos por dia, enquanto tinha que se alimentar ao menos de 3.600 calorias cotidianas (2.800 estimadas para um chapeleiro) e que podia exercer sua atividade no máximo 250 dias por ano, e das mulheres que de forma semelhante trabalhavam por um salário irisório, finalizando com aqueles em situação lastimável que recebiam 2,50 francos por dia $^{92}$. É o poder feérico, advindo da

$92 \quad$. Winok, p. 140. 
recuperação da idade de ouro no microcosmo de almanaque, que separa o teor de fetichismo de tais mercadorias para transformá-las em almanaquias do grande comércio de felicidade, oposto ao do Palais Royal ou de sua variante carioca no Ouvidor, onde os bilhetes de loteria, já premiados, são adquiridos justamente como bilhetes para adentrar nos comércios reservados para poucos, como se o esvaziamento do "balaio maravilhoso", permitisse, a preço módico, a cada compra anual, a aquisição das almanaquias sonhadas no abrir e fechar tais livros herméticos. A recuperação do mascatear, - que faz cintilar os olhos diante do novo ou da Verdade, em consonância com a poética de almanaque, - pelo reencontro da verdadeira idade de ouro, permite inferir a respeito da simbologia presente na caminhada infinda dos colporteurs e dos mascates, como representação do percurso quimérico da metáfora epopéica inscrita a partir dos feitos dos deuses e dos heróis modernos durante todo o ano, como se os tantos itinerários de tais mercadores ou heróis da arte da mascatagem, pela província, fossem atualizados nas cidades ideais, em que os cestos modernizados em papel módico, não azul para embalar pães doces, mas ambrosias deleitosas, recobrassem, na ode itinerante, o percurso encantatório dos prodígios de seu povo diante das intempéries inscritas na falaz Belle Époque.

É na tessitura das Repúblicas das delícias, Paris e Rio de Janeiro, que se observa o tecer dos sonhos de almanaquias, sendo possível flanar pelas ruas de "ouro em pó" ao folhear as páginas de tais livros herméticos, tendo, na oferta do Banquete poético, a garantia de riqueza e de virtude àqueles que se nutrem do poder Sublime da Poiésis, que salva o mundo dos males da vida moderna e possibilita o alcance do Belo, por meio do imaginário, incrito no ato criador a cada feitura de almanaque. 


\section{Prognósticos de bien-vivre: uma cartomancia de deleites nas mãos do flâneur-profeta}

A arte de auspiciar boa ventura, metáfora do exercício de Orfeu nos prognosticadores da vida ditosa no melhor dos mundos possíveis, reforça o microcosmo místico-poético dos almanaques, por meio da sustentação utópica que permite a salvação pelo encantamento para as agruras humanas, fomentando o engendro e a manutenção das cidades ideais, Paris e Rio de Janeiro, tendo no olhar visionário dos áugures, que revelam os signos escondidos das urbes na modernidade, a lisibilidade que resgata o sonhar com presságios de felicidade.

Esse microcosmo feérico e metafísico, onde se busca entender a Vida, "de maneira precária, mas totalizante" de acordo com Suassuna, possibilita aos leitores a salvação das problemáticas do mundo externo, sendo erigido pelo flâneur-poeta que possui simbolicamente, em suas mãos, uma cartomancia de deleites. A clarividência do poeta-áugure permite a seleção de temáticas que consolam seus leitores diante dos temores da vida, além de servir como material para a construção das urbes utópicas, o que torna as cidades lisíveis, com seus actantes auxiliares da nova Criação, responsável pelo sonhar com uma modernidade sem males. Ao escrever sua poética da modernidade nos livros sagrados, o flâneur-poeta dirige-se aos leitores que se veem, cada vez mais, isolados em seu mundo de fetichização de mercadorias e de aceleração do tempo. Tais problemáticas são tanto erradicadas, quanto denunciadas pela oferta inacabável de oráculos reveladores do Caos moderno, que permitem sonhar com o melhor dos mundos possíveis inscrito no Sublime, além da companhia assegurada pela parceria das infindáveis leituras e da colaboração dos próprios leitores na tessitura de tal sítio maravilhoso.

É no almanaque que se dá a lisibilidade de Paris e do Rio de Janeiro modernos, havendo uma espécie de atemporalidade assegurada pelo mito de cronos encarcerado, mesclada a uma proteção exacerbada, ora pelos santos, ora pelos astros e astrólogos, dentre outras formas contíguas de resguardo das intempéries cotidianas. Nesse microcosmo místicopoético, o flâneur-poeta seleciona uma série de actantes que o ajudam a construir as tão sonhadas cidades utópicas, cujo destino e administração da passagem do tempo são gerenciados por meio dos conselhos de homens dotados de poderes sobrenaturais, como o Monsieur Clay Burton Vance do Almanaque Brasileiro Garnier para o ano de 1914 e do Professeur M. Radja do Almanach Hachette para o ano de 1912. Tal colaboração na Criação anual de almanaque permite a segurança dos leitores em relação ao poder nocivo do Tempo Profano da modernidade, o que faz do engendramento a cada edição, uma espécie de renovação da Ventura dos habitantes das polis harmônicas, cuja inexorabilidade geradora da 
finitude já não existe, posto que o Sublime alcançado é a própria representação da perenidade sem males de tais sítios excelentes.

Com o intuito de edificar as urbes ideais, ofertanto remédio para todos os males, o flâneur-poeta vale-se de autoridades das ciências ocultas para assegurar seus leitores de que as faculdades de tais homens garantem o conhecimento do passado, do presente e do porvir, como uma espécie de consolo para as inquietações de qualquer natureza. Ora, é pela mesma ânsia dos primórdios de conhecer o porvir, que o homem moderno é movido, o que faz do canto do aedo, flâneur-poeta, o responsável pela tessitura da nova Criação que, por sua vez, representa simbolicamente um arsenal de advinhações e práticas cotidianas de deuses e heróis, como metáfora epopeica engendrada no início de cada ano. Tais prenúncios possibilitam que os leitores tenham na atualização dos oráculos, os santos, os astrólogos que prognosticam consultas enviadas pelo correio, os signos travestidos de uma roupagem periódica e tipográfica, uma espécie de manual de boa ventura que os livra dos maus agouros da modernidade e garante um devir repleto de delícias nas cidades excelentes.

É pelo ato poético anual, o dar forma à matéria preexistente moderna, que se volta às origens da Poiésis com sua alta representatividade mítica, tendo, segundo Commelin, a Grécia antiga como cenário dos oráculos proferidos de diferentes modos, sendo mister, em alguns casos, o cumprimento de uma série de cerimônias de preparação como, jejuns, sacrifícios, purificações, dentre outras. Tais presságios eram ainda enunciados pelas Pitonisas, as sacerdotisas de Delfos, mulheres que entre os gregos exerciam o ofício prenunciativo apenas uma vez por ano, em meados do início da primavera. O autor também aponta as Sibilas como mulheres dotadas de faculdades proféticas, cujo nome significa "vontade de Júpiter", sendo inicialmente sacerdotisas apenas desse deus, mas que logo expandiram seu ministério a todas as divindades, até mesmo nos países mais longínquos da Grécia. Apontavase a distinção entre os presságios e os augúrios, na medida em que estes eram baseados nos sinais interpretados conforme a arte de auspiciar, ao passo que o primeiros, eram ofertados aleatoriamente e entendidos por cada pessoa, de forma mais imprecisa e mais ocasional. É, pois, na supervalorização dos presságios pelos antigos, aos quais se recorria sobretudo no início de uma questão, nas primeiras horas do dia, no primeiro dia do mês e, sobretudo, no de um ano ${ }^{93}$, que se observa o diálogo com os prenúncios de almanaque, posto que seu caráter anual e também diário, profere a Ventura de bens e de conselhos, para suprimir os males modernos, pela Paidéia Poética tecedora da vida afortunada nas polis ideais.

93. Commelin, p. 377, 378, 379 e 384. 
A garantia de controle do tempo e da vida, nas cidades harmônicas, pode ser exemplificada por meio da análise do anúncio de um prognosticador que é apresentado com uma indagação bastante significativa que, na realidade, tem caráter afirmativo "Sera este homem dotado de um poder extraordinario?". Tal poder é reiterado e reforçado na seguinte frase, "Muitas pessoas da alta categoria e competencia dizem que elle lê na vida de cada qual como n'um livro aberto", atestando o teor de seriedade da propaganda e dos serviços prestados, posto que as pessoas que testemunham tais poderes são de alta qualidade e envergadura, assegurando os leitores de que não se trata de engodo. $\mathrm{O}$ discurso que assegura a clarividência do Monsieur Clay Burton Vance, em consonância com o universo místicopoético dos almanaques, como uma espécie de mise en abyme visionária, possibilita um jogo um tanto quanto persuasivo nos leitores, visto que o homem dotado de poderes extraordinários é apresentado pelas mãos do profeta maior, o flâneur-poeta que, por sua vez, está inserido em um microcosmo hermético, subjugado pelos poderes do macrocosmo, ou melhor, dos astros, que têm poder para influenciar o destino dos leitores.

A faculdade prodigiosa de Monsieur Vance continua sendo certificada na propaganda com um tom notório de presságio, assegurando os leitores de que podem ser informados a respeito de áreas que mais lhes interessam, como: "Negocios, Casamento, Mudanças de Vida. Occupações?", o que remete à angústia pelo porvir que sempre esteve presente no homem, haja vista o poder dos oráculos na Grécia antiga, ou ainda, os sacerdotes romanos que tiravam seus prenúncios do canto e do vôo das aves e do modo como se alimentavam, sendo uma constante inquietação a busca pelo controle do destino. $\mathrm{O}$ enunciador também garante os leitores de que existe a possibilidade de saber ao certo como devem pensar a propósito dos amigos e dos inimigos, além de conhecer o caminho para atingir o verdadeiro sucesso na vida: "Querem saber ao certo o que devem pensar dos amigos e inimigos, e conhecer o meio de alcançar o melhor êxito na vida?".

Logo abaixo um tom coercitivo é observado na medida em que o leitor é persuadido a escrever imediatamente, visto que dessa forma terá a gratuidade de “Leituras D'Ensaios e Horoscopos Parciaes", o que reforça a ideia de não se tratar de embute, ou seja, têm-se a impressão de que o lucro, caráter mercadológico do anúncio, é transformado em consulta gratuita reveladora dos bens e dos males que podem ser gerenciados da melhor maneira possível, a fim de manter longe os infortúnios da vida. 


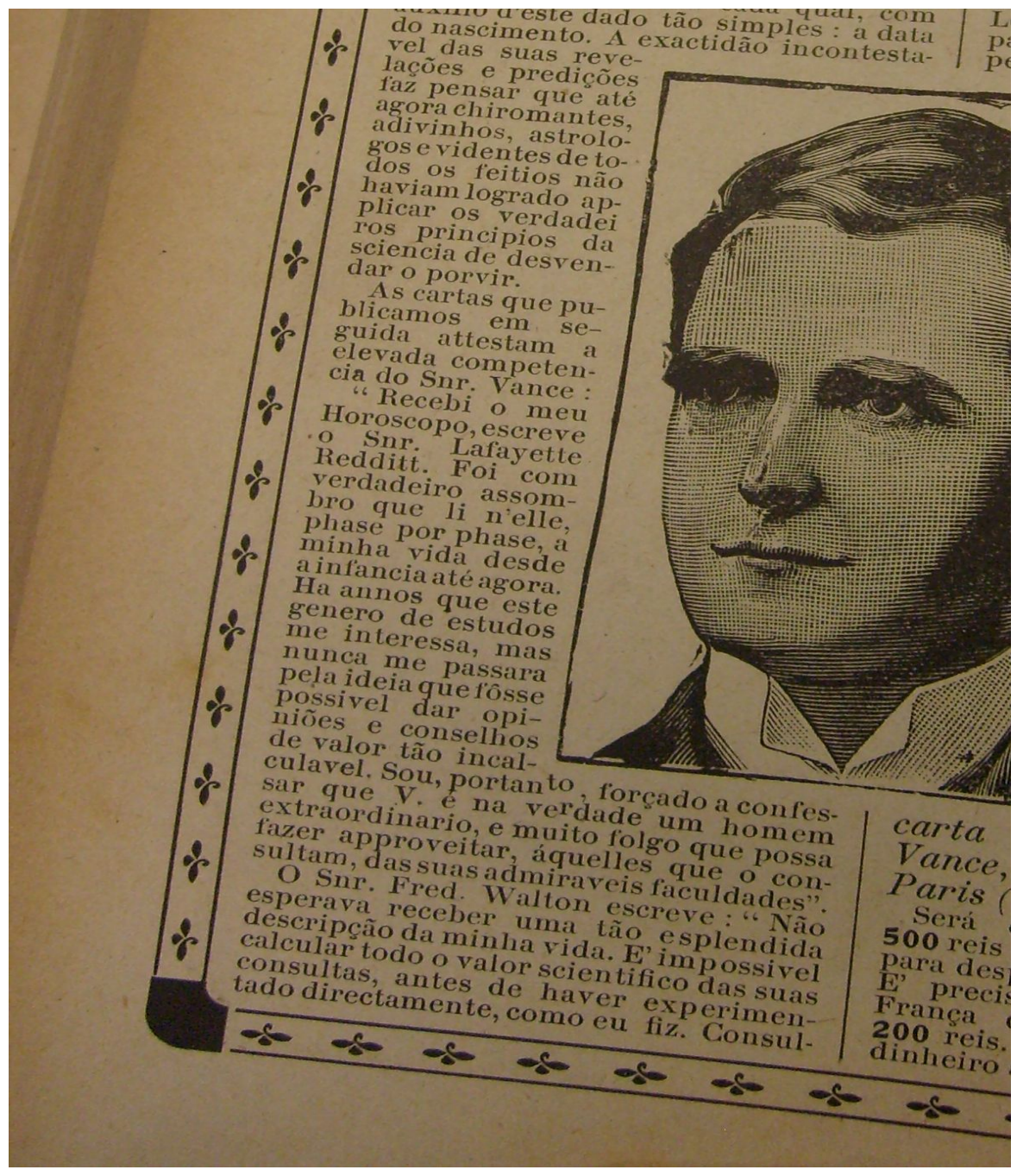

O primeiro parágrafo é direcionado, na atualidade em questão, a pessoas que se interessam pelas ciências ocultas, legitimando o poder de Monsieur Vance com um tom de moderação para não dar impressão de se tratar de charlatanismo, (...) "sem alardear dons especiaes, nem um poder sobrenatural, procura revelar o que a vida reserva a cada qual, com o auxilio d'este dado simples: a data do nascimento". Com apenas a informação solicitada, o prognosticador tem poder para revelar o que a vida reserva para cada indivíduo, além de convencer os leitores de que a precisão indiscutível de seus prenúncios, até o momento, não fora vivenciada por "chiromantes, adivinhos, astrologos e videntes de todos os feitios", por não terem aplicado "os verdadeiros principios da sciencia de desvendar o porvir". Ora, o discurso convincente adotado na propaganda permite que os leitores acreditem verdadeiramente que outros áugures, até então, não tiveram capacidade de manipular os 
princípios da ciência de maneira a revelar o futuro, sendo Monsieur Vance privilegiado por possuir tais faculdades.

O texto prossegue com mais certificações da legitimidade do advinho, com cartas publicadas que "attestam a elevada competencia do Snr. Vance", a do Snr. Lafayette Radditt, que demonstra tamanho espanto ao receber seu horóscopo e ler com tanta precisão a sua vida retratada fase por fase, desde a infância até o presente momento. $\mathrm{O}$ tom persuasivo perdura quando este leitor confessa que há tempos tal gênero de estudos lhe interessa, no entanto não acreditava ser possível obter opiniões e conselhos de tal magnitude. Finaliza, então, seu depoimento, com a certeza de ser deveras coerente em suas palavras, posto que é "forçado a confessar que V. é na verdade um homem extraordinario", por ter dados verídicos que comprovam tal competência.

O tom de convencimento é reforçado no depoimento subsequente, do Snr. Fred. Walon, que menciona o fato de jamais ter imaginado receber uma descrição tão magnificente de sua vida, além de ratificar o caráter científico das consultas de Vance, "É impossivel calcular todo o valor cientifico de suas consultas, antes de haver experimentado directamente, como eu fiz." O carácter científico como sinônimo de legitimação das predições reitera o discurso da recusa do logrado, assegurando os leitores de que ao escrever para tal referência nas ciências ocultas não correrão riscos de ser ludibriados pela manipulação leviana dos astros por um falsário qualquer. Ainda pelo depoimento de Walom, que se direciona a Vance pelo pronome de tratamento V. Exa, que, de antemão, indica autoridade e certifica não se tratar de pessoa comum, têm-se, ao consultar tal sumidade visionária, a "certeza de alcançar o exito que se deseja e a felicidade a que se aspira."

Em virtude do estudo comparativo aqui desenvolvido, é mister apontar um dado de extrema valia que corrobora tal leitura, o fato do enunciador, que mais parece tratar-se do próprio Vance, direcionar-se aos leitores do Almanaque Brasileiro Garnier orientando-os a fazer o quanto antes o pedido de consulta, pois desse modo, devido a negociações levadas acabo, o que remete à relação Brasil-França, podem receber a oferta de uma "Leitura d'Ensaio gratuita, ou Horoscopo parcial". Tal referência francesa no almanaque brasileiro evidencia o contexto da chamada Belle Époque carioca - haja vista que os almanaques reproduzem um panorama da cultura circundante, muitas vezes para denunciar seus males característicos da modernidade - havendo uma normatização do comportamento da sociedade ditado pelo afrancesamento dos usos e costumes, servindo como uma espécie de "domesticação" do povo em relação ao mundo de requinte e gosto europeu. Isso se reflete até mesmo na leitura dos 
astros, posto que o prestígio de ter uma consulta por um prognosticador francês, só validava tal atmosfera, além de servir como mais um artifício para legitimar e vender tal serviço:

Prova contundente disso encontra-se nas colunas dos jornais que atendiam à crescente ansiedade em relação à aparência e ao estilo em voga, evidentemente disseminada pelas camadas médias e superiores da sociedade carioca pelo menos desde a década de 1890. Muitas famílias da elite, acostumadas a passar longas temporadas em Paris e Londres, poderiam dispensar instruções quanto ao comportamento social considerado elegante na Europa. No entanto, outras famílias tradicionais (talvez menos viajadas), assim como os novos-ricos (e setores médios cada vez mais abastados e eurófilos) ansiavam por elas. Os jornais da belle époque perceberam e cultivaram essa ansiedade em face da adequação social. (NEEDELL, 1993, p.153)

O diálogo observado entre possíveis negociadores dos almanaques, quiçá entre Hypollite Garnier e Louis Hachette, os dois grandes livreiros responsáveis pela edição de tais livros, só reforça o viés comparativo do estudo proposto, bem como salienta que além das similitudes encontradas no gênero popular (almanaque) tanto da literatura popular brasileira quanto da littérature de colportage, têm-se ainda, em algumas seções, a constatação de uma profícua relação entre Brasil e França, ora pela oferta de produtos e de parcerias estrangeiras, ora pelos contatos feitos pelos próprios leitores solicitando informações contidas no almanaque francês, bem como no já elucidado cultivo dos franceses na história e na literatura brasileiras.

A leitura comparativa prossegue no último parágrafo, visto que o enunciador, o próprio prognosticador francês, parece ainda se direcionar aos leitores brasileiros, "Aquelles que desejarem, portanto uma descripção, da sua vida passada e futura", o que reforça o caráter divinatório da propaganda, dando a entender que há possibilidade de conhecer o passado com possíveis obscuridades que influenciam tanto o presente quanto o porvir, além da revelação do futuro evitando sofrimentos vindouros. Além da descrição da vida passada e futura por Monsieur Vance, os leitores ainda podem receber "uma enumeração das suas características, talentos e aptidões, uma indicação das occasiões que se lhes proporcionam", o que remete para o fato de que as admiráveis faculdades do vate não apenas revelam o passado e o futuro, mas também funcionam como uma espécie de orientação para descobertas pessoais, um teste de aptidão revelador da boa Fortuna. Assim, características, talentos e habilidades até então desconhecidos, podem abrir caminhos para oportunidades perdidas pela falta de conhecimento próprio, ou seja, os conselhos do adivinho revelam particularidades dos leitores que os salvam 
tanto das perdas provocadas pela falta de autoconhecimento, quanto do não aproveitamento de ocasiões oportunas.

Tal ventura dos leitores é garantida por meio de um processo simples, posto que não há mais necessidade de enviar uma série de informações para o cálculo certeiro das previsões, como " o nome, a morada, a indicação do sexo, a do dia, mez e anno de nascimento", o que atesta a clarividência do Snr. Vance, pois possui tamanho poder, quiçá por ter evoluído em sua caminhada enquanto áugure, que não necessita mais de dados que anteriormente utilizava, tampouco da "cópia feita pela própria mão dos seguintes versos: "Vosso poder é grande, é; [assombroso,; No mundo a fama diz:; Do meu porvir rasgando o veu; [nebuloso,; Dizei: Serei feliz?". Diante de tais versos e de algumas expressões do texto, observa-se que o enunciador procura utilizar um discurso o menos ostensivo possível, como ardil para convencer os leitores de que não se trata de pessoa imbuída de jactância. Sendo assim, os versos que reforçam sua fama e poder são eliminados, até mesmo para não dar a impressão, com uma linguagem elogiosa, de se tratar de charlatanismo.

O texto finaliza com informações de ordem prática a respeito do pedido de consulta, como nome completo do adivinho, número, bairro e país, além de instruções em relação ao valor cobrado pelo serviço, sendo de "500 reis de estampilhas do vosso paiz", justificando tal quantia apenas para despesas burocráticas, bem como de 200 reis para franquear as cartas, o que procura reforçar o caráter fidedigno do anúncio isentando-o de especulações comerciais.

A imagem de Monsieur Vance centralizada no texto tem o propósito de reforçar suas faculdades, na medida em que se nota um homem de olhar longínquo e de aparência judiciosa, ou melhor, um visionário capaz de revelar o passado, aconselhar sobre o presente e transformar o porvir dos leitores com receitas de eterna ventura.

Prosseguindo com o estudo comparativo, passa-se à análise do anúncio do Professeur M. Radja, do Almanach Hachette para o ano de 1912, cujo início dá-se com uma exclamativa que busca causar nos leitores uma espécie de convencimento carregado de admiração a respeito das faculdades do prognosticador, que conhece o passado e o futuro, "Cet homme connaît votre passé et votre avenir!". Como no almanaque brasileiro, o discurso persuasivo percorre todo o texto, reforçado pela informação de que há unanimidade entre todas as partes do mundo a respeito da clarividência do professor, como único que verdadeiramente revela, com exatidão, a vida de cada um, "Toutes les parties du monde sont unanimes à dire que nul autre que lui seul ne dévoile avec autant de précision, la vie de chacun.”. Outra similitude com o anúncio do adivinho Vance é o tom de comprovação utilizado, o que certifica os 
leitores de não se tratar de tapeação, posto que diariamente chegam de todas as partes atestações que comprovam o poder insigne de Radja, "Des quantités d'attestations lui arrivent chaque jour de toutes parts”, como o depoimento de Mr. L. H. que se dirige ao pro-

fessor destacando admiração pelo fato dele o conhecer, sem jamais o ter visto, melhor que seus amigos de trinta anos, "Vous me connaissez mieux, sans m'avoir jamais vu, que mes amis de trente ans:", concluindo que diante de tamanho prodígio não pode deixar de louvar suas faculdades, "c'est le plus bel éloge que je puisse faire de votre science." É, pois, tal poder grandioso de clarividência do professor Radja, apresentação que o elucida não como um adivinho sem formação, baseado apenas em suas intuições, mas um mestre na arte de auspiciar, que remete, como no almanaque brasileiro, ao ato poético do flâneur-poeta, à nova Criação responsável pela renovação da Sorte de bens que o Destino atribui a cada ente, traduzindo uma espécie de bom presságio todo início de cada ano e de bons augúrios diários como sustentação da cidade excelente no melhor dos mundos possíveis.

É na fabricação da nova realidade e dos novos seres a partir da massa caótica da modernidade, que se volta às origens da Poiésis mesclada a todo um universo mítico de deuses e de heróis, cuja relevância da prática de pressagiar o porvir elucida a cultura grega antiga, o que direciona ao exercício das divindades Parcas, que segundo Commelin, eram três irmãs, filhas, de acordo com os poetas, da Necessidade e do Destino, responsáveis pela ventura dos homens. Ainda são apresentadas como tão antigas quanto a Noite, a Terra e o Céu, nomeadas Cloto, Láquesis e Átropos, tendo por morada as regiões olímpicas, de onde zelam tanto pela sorte dos mortais, como pelo movimento das esferas celestes e da harmonia do universo, e possuem um palácio em que o destino dos homens está registrado em ferro e bronze, de modo que nada pode apagá-lo. Tais irmãs gerenciadoras do destino dos homens possuem nas mãos o fio emblemático que simboliza o decurso da vida, cujo andamento não pode ser comprometido por nada até que elas cortem a trama tecida cuidadosamente. Para melhor elucidação da função de tessitura do destino humano, é mister considerar a caracterização das três irmãs, Cloto, vocábulo grego que significa "fiar", parece a menos velha das Parcas e tem nas mãos o fio do destino dos homens, Láquesis, palavra grega que constitui "sorte" ou "ação de tirar a sorte", é responsável pela 
colocação do fio no fuso, já Átropos, nome grego que denota "inflexível”, representada como a mais velha, corta o fio que mensura a duração da vida de cada mortal. Além de tecer incansavelmente e cortar o fio do destino humano, ainda orientavam os nascimentos, eram responsáveis pela codução à luz e pelo resgate dos heróis que ousavam adentrar no Tártaro ${ }^{94}$. E ao exercício da eterna tessitura do destino dos homens pelas Parcas, que se compara a função do tecelão da ventura dos leitores, flâneur-poeta que, por sua vez, possui seus auxiliares, como Vance e Radja, responsáveis pela divisão de tarefas a fim de velar pela sorte dos habitantes das urbes quiméricas, quiçá o primeiro, fazendo uma analogia com as atividades das Parcas, possuidor do fio do destino dos seres, o segundo encarregado de por o fio no fuso do microcosmo de almanaque e o terceiro o próprio poeta-áugure, designado a cortar o fio que mensura a duração da vida, mas que é renovada, a cada nova Criação, como uma espécie de renascimento perene que permite, com as infindáveis receitas de longevidade, a supressão da finitude no melhor dos mundos possíveis. Como condutores do destino humano, ainda é importante salientar que semelhante às Sibilas e às Pitonisas supracitadas, os santos e os signos diários, também exercem a função de zelar pela sorte dos leitores dos almanaques, fazendo das leituras cotidianas, a dose de bom prenúncio necessária para afastar a desdita ao longo do dia e adentrar no microcosmo representativo do próprio Sublime.

Tal garantia de bons presságios é ofertada pelo anúncio de Radja, posto que o discurso é tecido simbolicamente à maneira das fiandeiras divinas, mas por meio de uma linguagem mística e persuasiva acompanhada de atestações, bem como de instruções quanto ao procedimento para pedido de consulta - como uma sorte de atualização dos cultos às divindades -, a exigência de mais informações em detrimento do anúncio brasileiro, como enviar por escrito, possivelmente para análise da maneira pessoal de traçar os caracteres, a data, o horário, o mês e o ano de nascimento, bem como acrescentar um envelope com endereço pessoal e dois francos (en bon de poste) para despesas de correio ou de selos para tais fins. Em seguida, o leitor recebe a carta planetária, Carte Planétaire e um estudo gratuito, étude gratuit, de sua vida a fim de conhecer a sorte de bens e de males que podem ser evitados, para alcance da boaventura. Ainda se pede para affranchir a carta, ou seja, pagar a taxa de envio de 25 centavos. Desse modo, o texto finaliza com uma frase um tanto quanto coercitiva, "Écrivez lui sans hésitation, la véracité de ses dires vous émerveillera”, o que além de impulsionar o leitor a escrever, também lhe certifica sobre a legitimidade do serviço e lhe garante admiração diante dos prenúnicos recebidos para uma vida afortunada.

94. Commelin, pp. 82,83 e 84. 
O leitor francês, como o brasileiro, também deve direcionar sua carta a um outro país, neste caso, Inglaterra, de cujo endereço 42 Bloomsbury, Square W. C. (Dept. 73) Londres, receberá o passaporte para uma vida repleta de êxito. Por isso, para adquirir tal ventura, o leitor deve ficar atento aos imitadores, "Ne pas confondre avec les imitateurs", o que novamente garante sua exclusividade e sua seriedade.

É, pois, com uma imagem um tanto quanto hermética, como no almanaque brasileiro, destacada no lado esquerdo do anúncio, que o prognosticador - com um olhar distante, sobrancelhas grossas, bigode espesso e mão no queixo, dando-lhe ar de pensador, além de sua vestimenta que remete a sua áurea mística - completa o discurso persuasivo, exercendo a aparência, o papel de convencimento para levar os leitores à aquisição de uma vida repleta de regozijo.

O velar pelo destino dos leitores dos almanaques, com os oráculos proferidos pelos homens dotados de poderes sobrenaturais, bem como pelo ato poético, a nova Criação, responsável pela sorte de bens a cada início de ano e de dia nas cidades excelentes, remete novamente à polis harmônica de Platão, à rememoração do mito de Er, que narra a sua descida ao Hades após ter sido ferido em uma guerra, na passagem dos grupos pelo prado, até chegar ao ponto alto onde uma luz reta, como uma coluna, tinha duas extremidades de suas correntes sustentando e mantendo coeso o globo celeste, em cujas pontas era suspenso o fuso da Necessidade que, por sua vez, fazia girar todas as esferas, uma espécie de rotação celestial. Era justamente sobre si mesmo e sobre os joelhos da Necessidade que girava o fuso, tendo no alto de cada círculo uma sereia que emitia um único som sempre no mesmo tom, eram oito no total, que colaboravam para a execução do mesmo acorde. Na experiência contada por Er, ainda havia três mulheres sentadas em tronos, as filhas da Necessidade, as Moiras, trajadas de branco e com guirlandas na cabeça, Láquesis, Cloto e Átropos, que cantavam hinos ao som da harmonia das Sereias, a primeira o passado, a segunda o presente e a terceira o futuro. Tais irmãs eram responsáveis pelo movimento celeste, Cloto ao tocar o fuso com a mão direita, fazia o círculo externo girar de maneira entremeada, enquanto Átropos, com a mão esquerda, fazia girar os círculos interiores, e Láquesis tocava intercalando as mãos ora uns, ora outros. Em tal sítio onde se dava a roatação celeste, chegam as almas que se apresentam prontamente a Láquesis, sendo colocadas por um profeta em seus devidos lugares, que tomando dos joelhos da divindade os quinhões e modelos de vida, anuncia, de um estrado, em alta voz, as palavras da filha da Necessidade, que expressavam o começo de outro período portador de morte para os mortais. Prossegue a promulgação com a informação de que não seria o dêmon que as sortearia, mas as almas que 
escolherriam um dêmon, sendo o primeiro sorteado também o primeiro a escolher a vida a que estaria vinculado pela necessidade, atentando para o fato de a virtude não estar presente em nenhum ente, que a honrando ou a desdenhando, cada um dela receberia mais ou menos, tendo responsabilidade quem a escolhesse, isentando o deus de culpa. Tendo apregoado as palavras de Láquesis, o profeta tirou para todas as almas as sortes, cada uma apanhou a que caiu perto de si, exceto Er, a quem não foi consentido. Tal procedimento permitia uma espécie de ordem no momento da escolha, para que, após colocado novamente no chão o grande número de modelos de vida, pudessem selecionar ${ }^{95}$.

É a partir da narrativa de Er, na República, retratando o que está reservado ao justo e ao injusto após a morte, que se elucida o papel das filhas da Necessidade na polis harmônica de Platão e nas urbes ideais de almanaque, posto que se as três irmãs são responsáveis pela sorte das almas e pela rotação celestial, cantando em harmonia com as sereias hinos, Láquesis o passado, Cloto o presente e Átropos o futuro, observa-se que o exercício de velar pelo destino dos mortais segue a mesma melodia cantada, pelo aedo, do zelar pela ventura dos leitores no microcosmo místico-poético, o que faz da arte do prenúncio a segurança da supressão de fatos nocivos do passado, a boa fortuna do presente e um porvir repleto de deleites nas cidades excelentes. Ora, se o poeta é auxiliar das divindades no momento da escolha dos modelos de vida pelas almas, também nos almanaques os assistentes do sagrado colaboram com a Paidéia Poética para orientar os leitores na seleção dos melhores caminhos a percorrer a fim de alcançar o Sublime, fazendo dos presságios dos vetas, dos cuidados diários dos santos, dos astros, bem como de outras práticas místicas, a tessitura do fio dos destinos com o ouro em pó da idade sem males, a fim de que ao final de cada tecelagem, a nova Criação, a linha sagrada não seja cortada, mas fiada ad infinitum como sinônimo do engendramento eterno de saborosas almanaquias.

Em virtude da análise dos anúncios, observa-se que o flâneur-poeta utiliza-se de inúmeros artifícios para construir as cidades utópicas, transformando os almanaques em uma espécie de brique-a-braque que possibilita a lisibilidade das urbes modernas, fazendo de tal microcosmo a tessitura do próprio Sublime, a mimesis salvadora e delatora do Caos circundante. Dando forma a matéria desordenada, o mercador de quimera edifica os paraísos artificiais por meio de uma embriaguez deleitosa, seja pelos componentes feéricos dos produtos, elixires e tônicos, seja pelo microcosmo místico-poético de salvação das intempéries da vida, elegendo um tempo outro, suspenso, renovado a cada nova Criação, cuja inexorabilidade é transformada em possibilidade

95. República, 616 c, 617 b, c, d, e, 618, a, pp. 411, 412 e 413. 
para sonhar, ou seja, um tempo onírico-sagrado nas cidades ideais, em que a rêverie é assegurada como remédio para os males da modernidade.

Além dos prognosticadores de boa Ventura no microcosmo místico-poético de almanaque, os leitores também são protegidos diariamente por outras práticas do universo representativo do sagrado, os santos, os horóscopos de pessoas célebres, os presságios astrológicos, o destino pelas cartas, a cartomancia que tem nas mãos o espelho da sorte, dentre outras, cujos signos astronômicos foram elegidos para análise, patronos asseguradores da boa Fortuna nas cidades ideais e intermediadores do caminho para o alcance do Sublime no melhor dos mundos possíveis.

É pela Paidéia Poética cotidiana que os leitores apreendem a arte da proteção sagrada incrita no arquétipo celestial de almanaque, a fim de enfrentar as intempéries da vida moderna, como se o tecer infindável, pelo ato poético, da nova realidade, resgatasse a miticidade perdida que sempre abrandou os desassossegos da alma desde os primórdios, o que pode ser elucidado no Almanaque Brasileiro Garnier para o ano de 1910 com seu calendário portador do signo de cada mês e no Almanach Hachette para o ano de 1911, que traz no L'Année Astronomique, Ano Astronômico, uma espécie de pedagogia para aprendizado da boa condução da vida pelos astros, ou melhor, a mimesis do modelo divino para tessitura da excelência das Repúblicas das delícias.

É, pois, a explanação assaz didática para leitura e compreensão do plano celestial, pela Paidéia Poética, no almanaque francês, que indica as Abréviations et Signes Astronomiques, abreviações e signos astronômicos, como as grandes estrelas portadoras de um nome próprio, mas que nas constelações são designadas, em grande parte, pelas letras do alfabeto grego, e os signos do zodíaco correspondentes as 12 constelações zodiacais, que constituem originariamente os meses. Para melhor assimilação, a pedagogia para compreensão do mundo divino, vale-se de um quadro bastante aclarador com a indicação das fases da lua, dos planetas superiores e inferiores, e da posição do Sol e da Terra na rotação celeste, ainda abaixo, relaciona todos os signos do zodíaco, e nas Indications Astronomiques, indicações astronômicas, cultiva os leitores para a leitura das cartas celestes, na página 245, o que contempla a duração do dia, a evolução da lua e a visibilidade dos planetas. É na Durée de l'Année, duração do ano, que os leitores têm a informação de que o ano tem por base a duração da rotação da Terra ao redor do Sol, e que o ano sideral é de 365 dias, 6 horas, 9 minutos e 9 segundos, ao passo que o ano trópico é de 365 dias, 5 horas, 48 minutos e 46 segundos, e o ano comercial é computado em 360 dias (12 meses de 30 dias). Nessa computação explanadora, o ano de 1911 é apontado como não bissexto, começa no domingo $1^{\circ}$ de janeiro e termina no domingo 31 de dezembro, apresenta uma duração de 365 
dias, 52 semanas e 1 dia, e os próximos bissextos indicados em 1912, 1916, 1920, 1924. A didática para compreensão do espaço sideral perdura na indicação de outros quadros elucidativos, a ver: Le soleil et le Zodiaque, o sol e o zodíaco, apontando a entrada do sol em cada período e no respectivo planeta, ainda os Éclipses , as Saisons, os eclipses e as estações em 1911, Les Mois et la durée des Jours, os meses e a duração dos dias e a, L'Époque de Moissons sur notre Globe, época das monções em nosso globo.

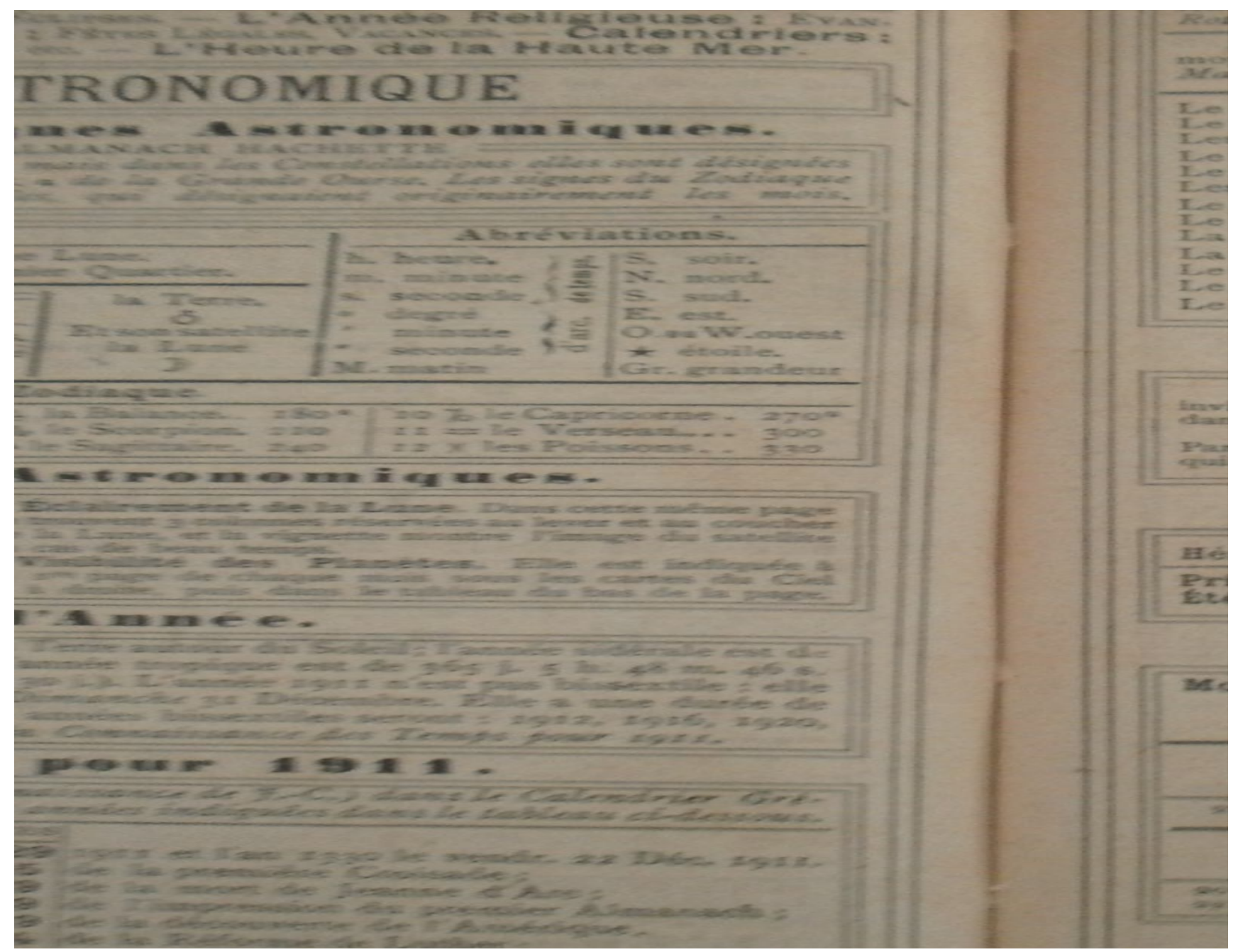

Considerando a imagem inserida no microcosmo místico-poético de almanaque, observa-se que a Paidéia Poética ministra aos leitores o cultivo do olhar para o Céu como sinônimo da acuidade de visão para contemplação direta do Sol, a fim de que possam compreender o mundo inteligível, com o intuito de que o mundo sensível, coberto pelo véu da falsa aparência moderna, possa ser revelado, pela apreciação e resgate do Belo, para alcance 
do Sublime, na cidade excelente da idade de ouro atualizada. Ora, o modelo divino cultivado na lição de astronomia constitui simbolicamente o próprio ato poético-cosmogônico gerador do melhor dos mundos possíveis a cada feitura anual de almanaque, não em um tempo determinado, tampouco na geração primeira advinda da divindade Caos, mas ininterruptamente, como rememoração do engendramento mítico representado nas sessões de almanaquias e responsável pelo sonhar com a nova realidade livre dos males característicos da modernidade. É pelo aprendizado celeste que a Paidéia Poética apresenta um protótipo divino para que a excelência da República das delícias seja constituída, o que remete à polis harmônica de Platão quando aponta que a convivência do filósofo com o divino e ordenado resulta no torna-se ordenado e divino, na medida do possível para um homem e, que jamais, uma cidade será ditosa se não a desenharem pintores seguidores de um modelo divino ${ }^{96}$. É a partir da analogia excelsa, embora a representação da República platônica não seja astronômica, mas em uma região transcendente, que se nota a pedagogia para a compreensão da repetição do ato criador, como se o entendimento - das fases da lua, do movimento e conhecimento dos planetas, dos signos do zodíaco, da lição da página 245 para leitura das cartas celestes, da entrada do sol em cada período zodiacal, dos eclipses e das estações para o ano de 1911, dos meses e duração dos dias e da época das monções no globo, - pudesse traduzir a própria mimesis da beleza celestial reiterada na Criação poética do melhor dos mundos possíveis, a cada tessitura de almanaque, para alcance do Sublime na perenidade de boa ventura. É ainda no cotejo com a polis ideal platônica que se menciona o diálogo entre Gláucon e Socrátes ao final do livro IX, na menção de que a urbe perfeita existe apenas em suas discussões, em nenhum outro lugar, mas que pode ser elucidada, quiçá no céu, sítio em que pode haver um modelo para quem anseie vê-la e, conforme o observado queira ele próprio organizá-la, não importando se ela existe ou não em algum lugar, porque ele tratará apenas do que é concernente a essa cidade, e de nenhuma outra ${ }^{97}$. É se valendo da pedagogia para o conhecimento do mundo célico que a Paidéia Poética ministra suas lições, buscando no cultivo concernente ao divino a referência para a edificação da cidade ideal, cujo engendramento pela ordenação e conhecimento dos astros, permite aos leitores da cidade grande a recuperação do olhar para a verdadeira beleza na retomada do ato criador do princípio do mundo, posto que em meio à velocidade exacerbada da modernidade, já não se sabe mais olhar diretamente para o sol ou para lua, mas somente para o que caminha no viés 
do utilitarismo. Ora, se a polis harmônica de Platão existe apenas nas discussões entre Gláucon e Sócrates, ou quiçá no modelo divino, afere-se que tal cidade excelente é concebida anualmente pela tessitura poética do microcosmo místico de almanaque, cujo céu, como arquétipo do sagrado, é rebaixado nas ruas da idade ouro moderna, o que permite a reconquista do tempo sem males pela poeticidade inscrita nas estrelas caídas para representação do Belo enfeado ou olvidado na modernidade.

É na adornação do Feio, da realidade caótica moderna, pela aplicação do modelo divino, que se nota mais um exemplo, do mesmo almanaque francês, de ensino para o conhecimento do plano celestial, a fim de que pelo movimento dos astros os leitores possam conduzir sua vida pelos caminhos afort la cidade excelente:

É, pois, na elucidação do modelo divino, a Description $\boldsymbol{d u}$ Ciel, descrição do céu, como didática para conhecimento do arquétipo a partir do qual a mimesis poética tece a urbe ideal, que se tem a visibilidade ou a acuidade de visão recobrada para enxergar diretamente os astros ou a verdadeira beleza do mundo, tendo nos desenhos o recurso pedagógico para melhor explanação do conteúdo celestial ministrado pela Paidéia Poética, sendo a explicação 
da disposição e do movimento das constelações e dos planetas, e a sua inter-relação, ao primeiro de janeiro às 9 horas da noite, a simbologia da boa condução da vida do Homem. Tal boa ventura é representada pelo caminhar moroso do boneco pelo curso repleto de neve e sem perspectiva, mas que, logo, pela trajetória dos planetas pelos pontos do zodíaco, avista a boa Fortuna representada pela morada aquecida, com conforto e com mantimento que, por sua vez, traduz a mansão celeste, encontrada no percurso caótico dos leitores na modernidade, onde se tem toda sorte de bens inscritos na idade de ouro de almanaque. Além da simbologia da boa condução do caminhar do boneco como sinônimo do zelar pela direção venturosa dos leitores, ainda se assinalam, pela Paidéia Poética, outras informaçães concernentes à lisibilidade dos planetas, como os horários do nascer, do passar pelo meridiano e do ocaso, do dia $1^{\circ}$ ao dia 16 de janeiro, bem como da origem do mês, que vem do nome Janus, antigo rei mitológico do Lácio, e a quem os romanos consagravam o primeiro dia do ano, remetendo novamente ao diálogo entre as cidades excelentes, posto que tanto Paris quanto Rio de Janeiro, presentificam o passado mítico pela rememoração dos antigos na computação dos dias, atualizando um pretérito de deuses e de heróis na modernidade ressequida pela racionalidade utilitarista. É dessa forma que, seja na História do Calendário do Almanaque Brasileiro Garnier, do último capítulo, seja na origem de cada mês nas Descrições do Céu do Almanach Hachette, que os leitores têm a dose diária necessária para sonhar com o movimento poético dos astros que computa o Tempo Sagrado assegurador da vida afortunada no melhor dos mundos possíveis.

A proteção do sagrado é, de forma semelhante, observada no Almanaque Brasileiro Garnier, não exatamente pelo Ano Astronômico francês, mas pelo calendário que apresenta periodicamente o santo patrono de cada dia, o signo responsável pelo mês correspondente e as fases da lua, o que traduz uma espécie de junção simbólica do arquétipo celestial guardador dos caminhos do leitores, oriundo da mimesis poética regeneradora do Belo em meio ao Feio moderno, para alcance do Sublime na cidade maravilhosa, Rio de Janeiro.

É pela consulta diária dos signos que se faz o cotejo com as orientações do Ano Astronômico francês, posto que se a boa condução da vida segue os presságios oriundos de cada tema natal composto por dez planetas, doze constelações do zodíaco e doze casas, além do exame das fases da lua, nota-se que é no plano celestial que os leitores encontram as chaves que abrem as portas para adentrar no melhor dos mundos possíveis, como se o modelo divino estetizado na poética periódica de almanaque, resgatasse o ato criador do princípio do mundo, e fizesse pela rotação cíclica, haja vista a passagem sucessiva dos planetas pelos 
pontos do zodíaco com intervalos simétricos, a própria representação do eterno engendramento da nova Criação no microcosmo místico de tais livros herméticos. É o ato poético tecedor na nova realidade que permite a feitura das cidades ideais como sinonímia do próprio modelo divino, posto que se a edificação da República platônica dá-se no mundo intelígivel, o supraterreno é declinado ao chão da idade de ouro carioca e parisiense, fazendo de seu caráter místico-poético o viés utilizado para a recuperação do Belo pela estetização mundo moderno, para alcance do Sublime, como se o universo terrestre e o celestial fossem fundidos na excelência da vida de eterno gozo das Repúblicas das delícias. Ora, é em harmonia com as fases da lua, por exemplo, para cortar o cabelo no melhor período, para os que querem volume, na cheia, para os que buscam a sua supressão, na minguante, ou para aqueles que anseiam pelo crescimento rápido, na crescente, ou ainda em consonância com os prenúncios dos signos, para fechar um contrato, para mudar de emprego, para iniciar um novo relacionamento, dentre outros, bem como no exame diário de cada santo para a boa condução de suas práticas cotidianas que exigem atitudes judiciosas, o próprio sincretismo sagrado representativo da supremacia do mundo divino, como se o ato criador fosse reinventado diariamente, além de sua constituição simbolizada no início de cada ano.

Tal proteção divina para uma vida afortunada é reforçada pela quantificação do sagrado na cidade excelente, posto que os leitores já não têm apenas o signo de touro, Taurus, representado pelo símbolo na abertura do calendário, reponsável pelo mês em questão, mas também daqueles que regem todos os outros meses, designados para o bom encaminhamento da vida conforme a data do nascimento de cada ente, como um zodíaco todo a seu favor representado pela boa disposição dos planetas nos temas e sua disseminação no céu de almanaque; também do santo diário, mas que é visto como uma espécie de integrante de uma legião protetora, haja vista os trinta ou trinta e um dias, que ainda podem ser multiplicados pelos 365 dias do ano; e das quatro fases da lua, que também se somadas aos eclipses lunares que as fazem invisível para todos os observadores terrestres, nutre uma sorte de cuidado simbólico inscrito no caráter misterioso de seu apagamento; todos representantes do plano supraterreno que já constituem a nova realidade, a idade de ouro moderna, sem pesares e preocupações, como se a época, em que os homens e os deuses dividiam o mesmo espaço, fosse recuperada no Céu de almanaquias com seus astros condutores da vida feliz no melhor dos mundos possíveis.

É no ato poético, como mimeses transformadora da realidade caótica moderna em nova Criação, cuja sacralidade traduz o belo em si inscrito no mundo inteligível e recupera a 
miticidade perdida em meio a ratio destruidora do sonhar, que se nota a edificação da República imaginada por Platão nas polis harmônicas de almanaque, posto que se no céu há o modelo para quem quer vê-la, já não há necessidade de dirigir-se para o alto, mas sim para o próprio engendro excelente, estetizado a partir do modelo divino, e traduzido pela totalidade do sagrado da Terra sem Males. Ora, é a Poiésis o Demiurgo responsável pela transformação do Caos moderno em Cosmo maravilhoso, como se a feitura divina do mundo fosse constituída, não em um tempo definido, mas recriada anualmente e conservada, pelos representantes do sagrado e de suas práticas, durante todo o ano no microcosmo misticopoético de almanaque.

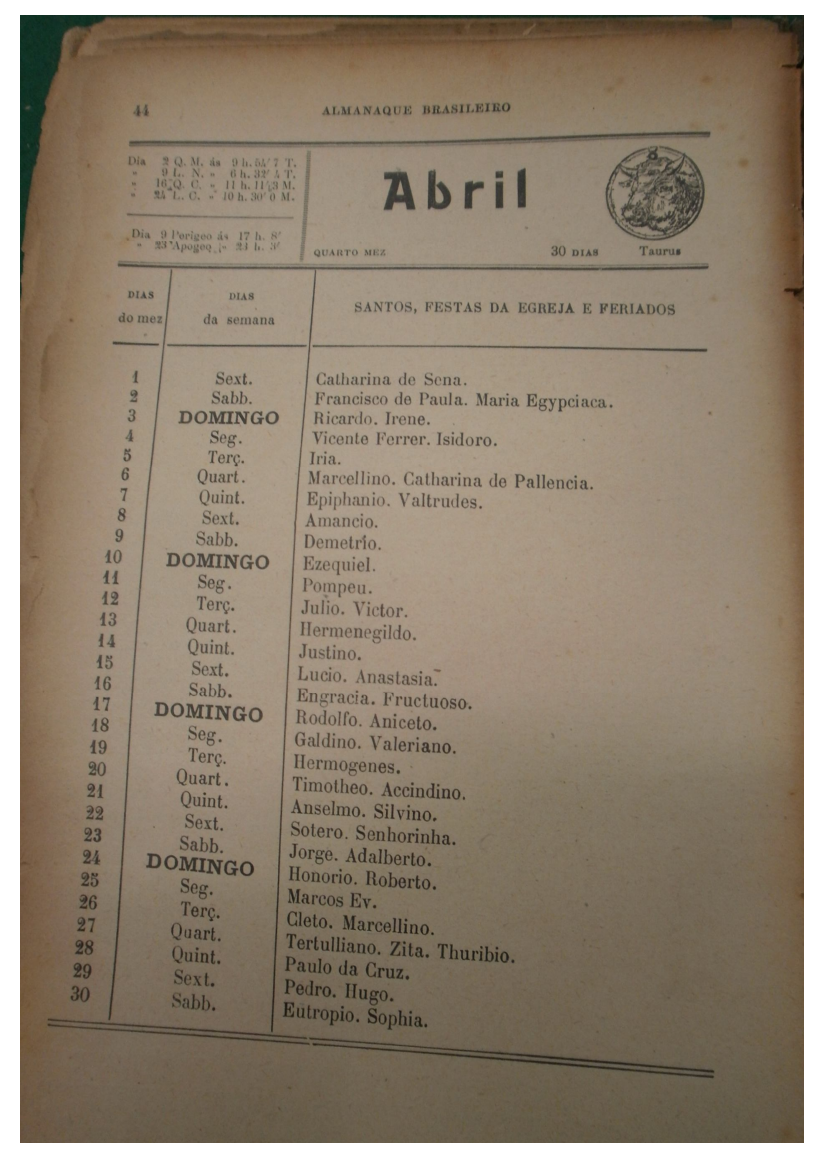

É a feitura poética incessante que remete ao céu caído nas ruas da idade de ouro moderna, como se a Paidéia Poética, - orientadora para o aprendizado da contemplação do Belo apagado pelo profano travestido de progresso e utilitarismo, - fosse responsável por cultivar os leitores para a compreensão da Verdade inscrita na poeticidade das constelações e estrelas da galáxia quimérica portadora de toda sorte de bens, elucidada pela imagem 
intitulada Aspecto do Céu no almanaque brasileiro, de forma semelhante à Descrição do Céu no almanaque francês.

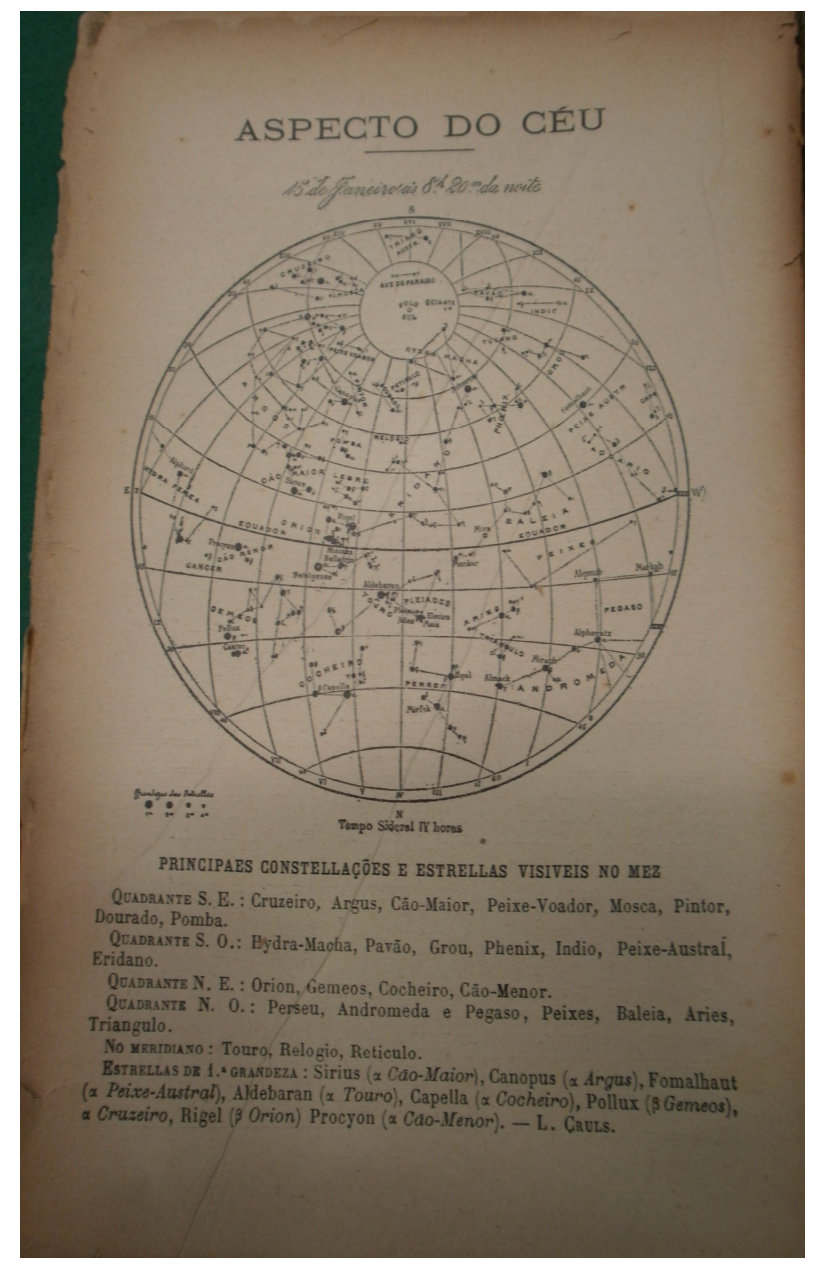

É na estetização do mundo celestial, como mimesis do modelo divino para encontro do Sublime em meio à realidade caótica moderna, que a Paidéia Poética cultiva os leitores para o aprendizado do alto, ou seja, o apreender a olhar diretamente o espaço célico para ser curado da cegueira que não lhe permite enxergar o Belo enfeado pelos males circundantes. É a lição de contemplação das principais constelações e estrelas visíveis do mês, o execício terapêutico para sanar a enfermidade que obscurece as retinas para a acuidade de visão concernente à verdadeira beleza do mundo, cuja poeticidade de almanaque é a própria tecelã do céu refungente que transluz o conhecimento aclarador da sombriedade inscrita na modernidade. Mediante a condição de aceleramento do tempo, da busca desenfreada pelo progresso e do utilitarismo característicos das cidades grandes na modernidade e, em particular da chamada Belle Époque, como Paris e Rio de Janeiro, a Poiésis já não tem mais lugar em meio à 
supervalorização da ratio, o que faz rememorar a Initiation Poétique do primeiro capítulo, e que neste é recobrada pelo aprendizado do olhar novamente para o céu, da contemplação ou do ócio criativo e revelador do Belo pisoteado pelos passos apressados dos transeuntes, que nas polis excelentes podem recobrar a beleza que se esvaiu, com o exame, das estrelas e das contelações, sob a instrução da Paidéia Poética, a ver: no Quadrante S.E., em que é visto as Cruzeiro, Argus, Cão-Maior, Peixe-Voador, Mosca, Pintor, Dourado, Pomba; no Quadrante S. O, as Hydra-Mancha, Pavão, Grou, Phenix, Indio, Peixe-Austral, Eridano; no Quadrante N. E., as Orion, Gemeos, Cocheiro, Cão-Menor; no Quadrante N. O., as Perseu, Andromeda e Pegaso, Peixes, Baleia, Aries, Triangulo; no Meridiano, as Touro, Relogio, Reticulo; e ainda no espetáculo estético produzido pelas Estrelas de $1^{\text {a }}$ Grandeza, as Sirus (Cão-Maior), Canopus (Argus), Fomalhaut (Peixe-Austral), Aldebaran (Touro), Capella (Cocheiro), Pollux (Gemeos), Cruzeiro, Rigel (Orion) Procyon (Cão-Menor). - L. Cruls. É, pois, o aprendizado poético que permite a recuperação do Belo, sendo contemplado exatamente aos 15 de janeiro às $8 \mathrm{~h} 20 \mathrm{~m}$ da noite, na cidade carioca, e como já mencionado, ao $1^{\circ}$ de janeiro às $9 \mathrm{~h}$ da noite, na urbe parisiense, o que não se trata de um acontecimento efêmero, haja vista a sua renovação mensal e a cada feitura de almanaque, no entanto epifânico, como se o próprio modelo divino se manifestasse incessantemente, em meio ao profano, para tessitura do Tempo Sagrado na idade de ouro moderna.

É o Tempo Sideral de IV Horas do Aspecto do Céu no almanaque brasileiro e o Tempo Sideral não explicitado da Descrição do Céu no almanaque francês, em consonância com a miticidade do Tempo Sagrado do microcosmo místico-poético, que dirigem a vida dos habitantes das polis harmônicas, sítio feérico em que os astros possibilitam a boa condução nos caminhos ditosos do melhor dos mundos possíveis, cujas estrelas e constelações, guias da boa Fortuna, nos quadrantes calçados de poeticidade, revelam o Belo perdido, para alcance do Sublime, na idade de ouro reencontrada. 


\section{Domestição poético-cíclica do tempo: cronos domado pelos calendários}

Considerando o engendro anual do microcosmo quimérico de almanaque, pelo ato poético do flâneur-poeta, observa-se no cantar do aedo uma espécie de amansamento do Tempo Profano pela melodia resgatadora do in illo tempore, cujo retorno à verdadeira idade de ouro permite a conquista da Terra sem Males onde o Belo é resgatado pelas tintas míticosagradas tecedoras das cidades excelentes. É, pois, no eterno retorno que a mimesis da modernidade é tecida pelo ato criador, tendo sua manifestação no canto representativo do falar moderno, como tradução da beleza escondida ou da feiúra encobridora da Verdade, a purgação das emoções - por meio da Poiésis - olvidadas no utilitarismo, para uma catarse libertadora inscrita no próprio Sublime.

É na Criação anual do flâneur-poeta, como recuperação do Tempo Sagrado, que se volta ao berço da Poiésis, tendo na Paidéia grega a caracterização da educação poética ministrada aos leitores dos almanaques, como uma espécie de feitura de uma nova Teoria da Poesia que cultiva os leitores para o alcance da Plenitude nas Repúblicas das delícias. Ora, é o poder Sublime da poesia, tecedor de um devir sem males e recuperador da excelência do $a b$ origine, que remete a Aristóteles com sua Arte Retórica e Arte Poética, preservando o estético de sua redução a juízo moral, proposição corrente no período antigo, mas como uma mimesis que denuncia o falacioso arranjo apresentado, fazendo do ato de imitar, a verdadeira ordenação do Caos em Cosmo, como revelação do Belo escondido nas entranhas das mazelas da modernidade. É na pedagogia para obtenção do Belo, tendo na elucidação da produção poética em si mesma e de seus diversos gêneros, que Aristóteles discorre sobre a poesia e a imitação, apontando a epopéia como aquela que se utiliza apenas da palavra simples e desnuda dos versos, ora combinando diferentes metros, ora prendendo-se unicamente a um tipo. O autor ainda menciona os gêneros que se utilizam de todos os meios de expressão como, o ritmo, o canto, o metro pelos autores dos ditirambos, de nomos, de tragédias, de comédias, que são diferenciados por meio da maneira como empregam tais meios, se conjuntamente ou separadamente, de cujas disparidades entre as artes é que se propõem a imitação ${ }^{98}$. É na lição para alcance do Sublime, pelo fazer poético, que se faz o cotejo entre a função da Paidéia Poética de almanaque e a Teoria aristotélica, fazendo do canto do flâneur- 
poeta a criação de um novo tempo, não mais aquele marcado pela inexorabilidade que traz consigo a finitude, mas a geração de um decurso inscrito no Belo como sinônimo do Tempo Sagrado que não se esvai com o devir, mas está diluído na magia das folhas dos calendários e das receitas de almanaque que guiam os leitores para o Divino. É na miscelânea, de meios de expressão de alguns gêneros, citada por Aristóteles, que se elucida a tessitura poética de almanaque, posto que nos diversos modos do fazer artístico das cidades excelentes, nota-se a estetização do mundo moderno na presença dos teatros, dos circos, das sessões literárias e de outras Artes, o próprio poema épico como metáfora de tais livros herméticos, como polifonia de atos criadores, para a conquista do Tempo Sagrado tecido, anualmente, com os fios da Poiésis.

É, pois, a figura da bússola poética, tecedora e condutora da sorte dos leitores, que remete à simbologia contida nas imagens dos relógios marcadores do Tempo Sagrado nas urbes ideais, como representantes do decurso tecedor do Belo ad infinitum, em uma espécie de mimeses salvadora e transformadora da finitude moderna, com seus males, em perenidade da condição ditosa na recuperação da idade de ouro. Logo, o tempo é mensurado, no Almanaque Brasileiro Garnier para o ano de 1911, com os ponteiros quiméricos dos relógios que representam as horas, a partir do horário exato (12:00) da eudaimonía na polis excelente, Rio de Janeiro, das diferentes cidades do mundo: 


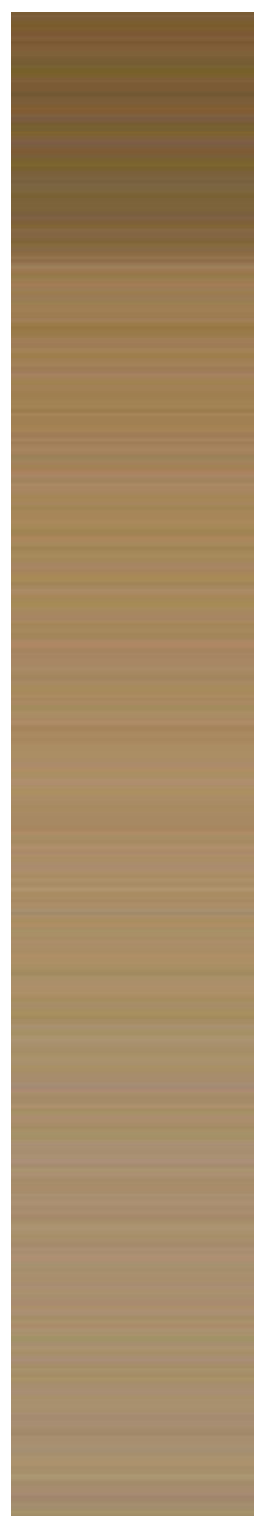

É pela mimeses da modernidade que o flâneur-poeta corrige os males circundantes, estetizando o Feio para o acabamento do Belo na polis ideal, tendo na simbólica da supressão da inexorabilidade do tempo, pelo ato criador eterno, representativo de uma espécie de controle do decurso, a supressão dos desassossegos causados tanto pela certeza do fenecimento e, por conseguinte, do envelhecimento, quanto das problemáticas modernas traduzidas, pelo Caos organizado em Cosmo místico-poético, a cada edição de almanaque. Logo, é na hora excelente, na badalada dos pêndulos do Tempo Sagrado pelo canto poético, que os leitores têm a garantia do devir maravilhoso, do soar da melodia da eterna felicidade na urbe ideal, como cura dos enganos da falsa aparência moderna para alcance do Sublime. É, pois, na representação do domínio da passagem do tempo, com os relógios acertados no horário fantástico, que se observa a elucidação do melhor dos mundos possíveis, posto que 
não apenas a polis perfeita está em consonância com o Ideal, mas todas as outras cidades que têm simbolicamente seus ponteiros ajustados na excelência, o que assegura os leitores de que a realidade engendrada pelo ato poético faz nascer uma nova Terra sem infortúnios e sem preocupações. Ora, é na segurança de uma nova gênese poética que permite o alcance do Belo, que se observa ainda a explanação dialógica da edificação das Repúblicas das delícias, visto que Paris representada pelo relógio vizinho ao do Rio de Janeiro corrobora a sintonia poética entre os ponteiros que marcham sob a melodia do canto sagrado intercambiador de almanaquias entre as polis harmônicas. O diálogo Brasil-França é ainda reforçado no destaque que se dá a tais cidades, caracterizadas como as principais do melhor dos mundos possíveis, separadas das demais, ou seja, ganham notoriedade aos serem colocadas, dentre as mais influentes, no topo hierárquico-temporal representado pelos relógios, como se além de pertencerem a tal universo maravilhoso, ainda tivessem evidência diante do excelente.

Considerando o alcance da idade de ouro por meio da Poiésis, do Tempo Sagrado traduzido pelo exercício de uma espécie de Cômputo eclesiástico travestido de poeticidade, que segundo Aurélio, é constituído de uma série de regras pelas quais se definem as datas das festas móveis das igrejas cristãs ${ }^{99}$, que se observa a contagem dos dias, dos meses e dos anos nos almanaques, posto que seu caráter mensurador do decurso carregado de misticidade, indicando as datas das festas móveis e fixas a cada feitura anual do Belo, tendo no conjunto de normas feéricas a indicação de um devir cíclico e regenerado, - a própria elucidação da Criação incessante que salva os leitores do Tempo Profano. É, pois, nas festividades sagradopoéticas que também computam o tempo no microcosmo de almanaque, que se pode dançar, ficar à-toa, alimentar-se do Banquete de deleites, em um decurso quimérico com toda sorte de bens renovada ininterruptamente, como a alegria infindável do melhor dos mundos possíveis. É a partir do resgate, pela Poiésis, do in illo tempore, que se volta ao berço da poesia ocidental, a Grécia antiga com seus mitos e heróis, tendo na figura das divindades Horas, o fomento poético-místico para a contagem maravilhosa do tempo nos almanaques, deusas que, segundo Commelin, tinham no nome, a designação primitiva atribuída, pelos gregos, ao ano e não à representação dos dias. Elas eram filhas de Júpiter e Têmis, apresentadas por Hesíodo como, Eunomia, Dice e Irene, representantes respectivamente da Ordem, da Justiça e da Paz, e por Homero, chamadas porteiras do céu, a quem confere a tarefa de abrir e fechar as portas eternas do Olimpo. Inicialmente a mitologia grega apontava apenas três Horas ou três Estações: a Primavera, o Verão e o Inverno, acrescido posteriormente pela adição do Outono 99 . Dicionário Aurélio, Nova Fronteira: 2000, p. 165. 
e do solstício do inverno, para caracterização do período frio, cuja criação de mais duas Horas, Carpo e Talete, ficou reservada aos cuidados das frutas e das flores. Também há a menção de que no momento em que os gregos dividiram o dia em doze partes iguais, os poetas multiplicaram o número das Horas até doze, designadas as doze irmãs e destinadas a servir a Júpiter. O autor ainda elucida as divindades como responsáveis pela educação das crianças e pela codução da vida dos homens, o que explica o exercício das Horas de assistir a todas as bodas celebradas na mitologia ${ }^{100}$.

É, pois, na representação das Horas como divindades responsáveis pela divisão dos dias e dos anos, bem como do velar pela vida dos homens, que se observa o diálogo do sagrado com a contagem do tempo nos almanaques e com o zelar pelo destino de seus leitores, havendo uma miscelânea harmônica de leituras a respeito dos ciclos cósmicos, traduzida ora pelo movimento dos corpos celestes, ora pela condução divina, além de outras formas contíguas de manifestações místicas. Todas colaboram na feitura do Tempo Sagrado, que permite o eterno retorno grego no viés da repetição criadora infinita, pelo ato poético, tecedor do Sublime. Logo, sob os auspícios não das Horas, mas dos santos, dos astros, dos signos e dos áugures, que os leitores têm a garantia da boa sorte presente na regeneração do tempo a cada engendro de almanaque, cujos relógios supracitados são mantidos em funcionamento pela Poiésis que tece uma atemporabilidade, no sentido de renovação incessante do decurso, caracterizadora da salvação dos males da modernidade na cidade excelente. É na tarefa das Horas, confiada por Homero, de abrir e fechar as portas do Olimpo, que se observa, no rebaixamento simbólico do céu ao chão de almanaque, os porteiros representantes do universo místico-poético travestidos de um manto de sacralidade como auxiliares da abertura da passagem que leva ao conhecimento da Verdade. É na caracterização de Hesíodo, concernente às divindades, que ainda se faz a leitura comparativa no que tange à função das Horas, pois ao serem designadas pelo poeta como, A Ordem, a Justiça e a Paz, infere-se a analogia simbólica com o exercício dos mensageiros das boas novas nos almanaques, posto que seus prognósticos ditosos colaboram na tessitura das cidades ideais sob a égide da ordem, da justiça e da paz, bem como da fiação infindável do véu temporal sagrado que protege a ventura das estações, durante o ano todo, das intempéries da modernidade no microcosmo místico-poético da excelência. Da tarefa de guardiões da vida afortunada, passa-se à divisão do dia em doze partes iguais pelos gregos, a partir da qual, à multiplicação, pelos poetas, das Horas até doze, o que direciona ao ato poético anual do 100. . Commelin, pp. $80-81$. 
flâneur-poeta, subdividido em dias, meses e anos, cuja atenção periódica da Paidéia Poética é a elucidação da segurança de horas de regozijo desde a aurora até o ocaso nas Repúblicas das delícias.

Semelhante à computação do tempo na polis harmônica carioca, combinada à proteção da vida dos leitores, também se analisa a mensuração do decurso poético-regenerador na cidade parisiense, no Almanach Hachette para o ano de 1911, cujo texto para análise intitulase L'Heure et La Mesure Du Temps, a hora e a medida do tempo, com outros dois subtítulos Quand il est Midi à Paris, Comment régler sa montre sur le Soleil, quando é meio dia em Paris e como acertar o relógio a partir do sol.

É, pois, de forma análoga ao cômputo maravilhoso do tempo na cidade ideal, Rio de Janeiro, que o devir repleto de boa ventura é assegurado pela mimesis, tecedora do Sublime, na urbe excelente, Paris, a partir da matéria caótica da modernidade. Nessa perspectiva, a contagem do decurso é realizada pela Paidéia Poética que, já no início do texto, adota uma pedagogia temporal para explicar aos leitores que a variação das horas depende da longitude do lugar, o que é elucidado na adoção pelos países, Grã-Bretanha, Holanda, Bélgica e Espanha, do horário da Europa Ocidental que retarda quatro minutos; ao passo que a hora central na Alemanha, na Suíça, na Itália, na Áustria, avança cinquenta e um minutos do horário de Paris, o que é afixado no quadro externo das estações. O tempo é mensurado da mesma forma que na cidade brasileira, a partir do horário preciso (12:00) de Paris, o que também remete ao controle certeiro do decurso pelo alcance do Tempo Sagrado na urbe ideal parisiense que, por sua vez, faz com que os ponteiros de seu relógio girem de acordo com o devir excelente do melhor dos mundos possíveis, cuja elucidação simbólica das cidades e de alguns países, em consonância com a hora Ideal, representam a Terra sem Males oriunda da feitura anual do microcosmo quimérico. Ora, quando é meio-dia na cidade excelente, a mensuração do tempo nas outras urbes dá-se por meio do quadro explicitado na imagem, que elenca uma série de horários a partir da simbólica Hora Ideal representativa do alcance do Sublime. Diante de tal imagem, a presença da cidade do Rio de Janeiro, dentre as principais apontadas, corrobora simbolicamente o diálogo Brasil-França intercambiador das almanaquias para deleites e indicador das polis harmônicas como representação da Plenitude alcançada no mundo sem males. Nesse, o Tempo Sagrado é cronometrado e tecido, de maneira infindável a cada edição de tais livros herméticos, como se o Belo jamais tornasse Feio com a inexorabilidade do decurso, mas fosse restaurado, para manutenção da eterna beleza inscrita na Terra de boa ventura, já indicada na imagem do Eldorado analisada no primeiro capítulo, 
que além de representar o Pays d'Utopie com suas cidades ou o Pays de Cocagne, também caracteriza a metáfora do melhor dos mundos possíveis erigido no microcosmo místicopoético de almanaque. Logo, as cidades ideais, Paris e Rio de Janeiro, têm na caracterização do micrococosmo excelente, a elucidação do macrocosmo sem infortúnios, o mundo ordenado pelo ato poético do Demiurgo flâneur-poeta, alcançado pela leitura diária dos almanaques por todos os entes, em qualquer lugar que estiverem no mundo das maravilhas.

É pela Paidéia Poética que o flâneur-poeta cultiva os leitores para a conquista do Sublime, tendo na lição poética de regular o relógio sob o sol, a representação simbólica do cômputo Ideal, como metáfora do próprio alcance do Bem e do Belo nas cidades excelentes, fazendo do ato de acertar as horas para a supressão da falsa aparência moderna, a conquista do Tempo Sagrado mensurado e tecido pela representação do astro indicador do mundo inteligível, cuja poeticidade dos solstícios, das urbes ideais, elucida o decurso excelente assegurador da vida afortunada e do devir sem males, no melhor dos mundos possíveis. Ora, a pedagogia para o Belo, o olhar o sol a fim de ajustar os ponteiros para a Verdade, orienta os leitores com informações concernentes à medição do tempo ao longo dos dias que, por sua vez, apresenta diferença no tocante às horas serem mais ou menos longas, além de apontar o horário do meio-dia como marcador da metade do dia apenas nos solstícios. A didática para o excelente ainda menciona a criação do "temps moyen, toujours régulier", tempo médio, sempre ajustado, entretanto se o leitor quiser acertar seu relógio sob o sol, como segunda opção, deve adicionar ou subtrair, de acordo com o quadro elucidado, o número indicado para cada dia no horário exato do meio-dia, ou seja, no momento da passagem do sol no meridiano. 


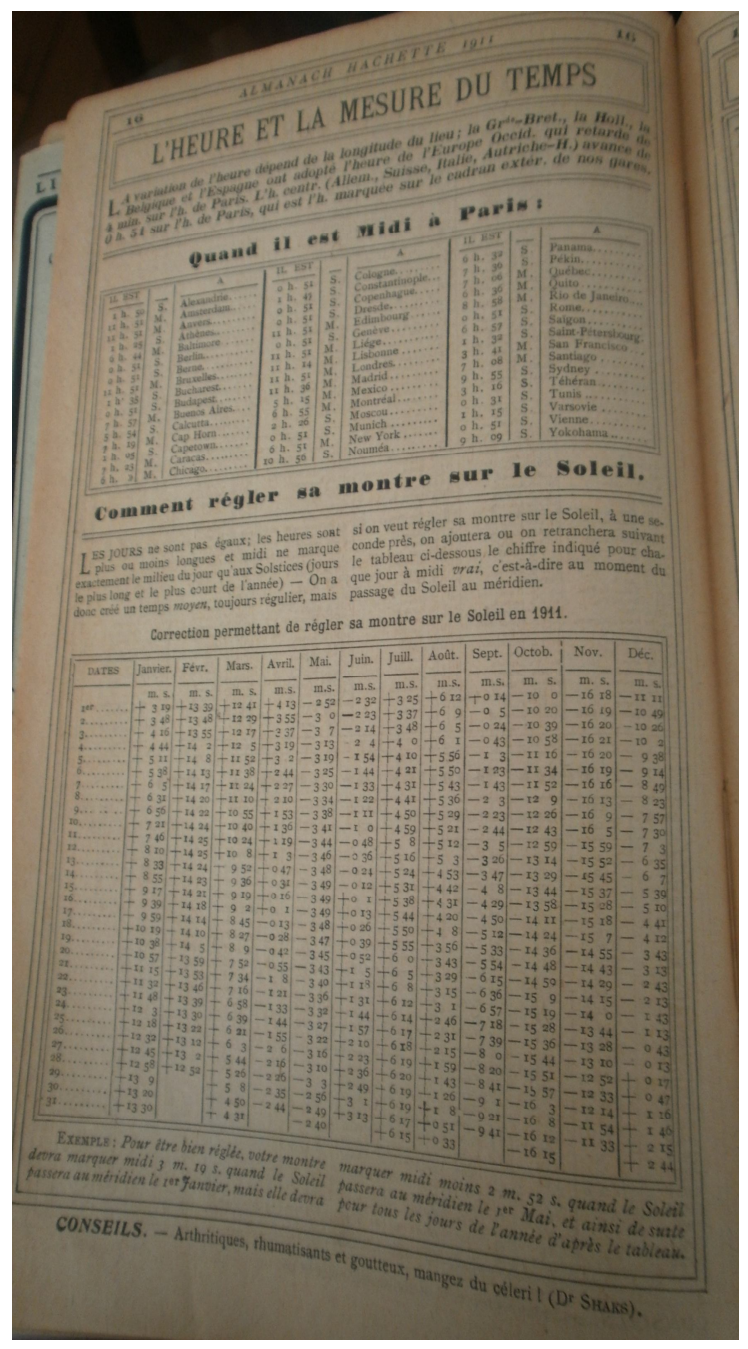

É, pois, na mensuração do tempo na cidade excelente, Paris, que o leitor pode olhar diretamente para o sol, galgando simbolicamente os degraus até alcançar a cura de seus males como sinônimo das problemáticas da modernidade, para então, realizar, pela Poiésis, o ajustamento permanente de seu relógio a partir da contemplação direta do astro, o que é elucidado como oferta de boa ventura para o ano de 1911, com as datas e os respectivos meses de melhor colheita nas estações em que as Horas, divindades supracitadas e atualizadas, regem a vida e são responsáveis por toda sorte de bens em tal microcosmo místico-poético. Na urbe harmônica, as deusas, traduzidas pelo misticismo-poético dos representantes do sagrado, têm a função de orientar de maneira assaz didática, por meio da Paidéia Poética, o cômputo do Tempo Profano para alcance do Sublime, com um exemplo deveras aclarador para eficácia de tal método condutor do Belo, observado na proposição de que para o relógio estar bem ajustado deve marcar três minutos e dezenove segundos, quando 
o sol passar no meridiano no dia primeiro de janeiro, mas deverá marcar meio-dia menos dois minutos e dois segundos, no momento em que passar no meridiano no dia primeiro de maio, e desse modo, sucessivamente, durante todos os dias do ano segundo o quadro elucidado. É pelo ato de reger a vida dos leitores, que os emissários do divino nos almanaques, como atualização das divindades Horas, têm poder para tirá-los da caverna que impede a visão límpida da Verdade, tendo na imagem do engendro do bem, segundo Platão, o sol, a representação do mundo inteligível, que ao cultivar os habitantes das polis harmônicas para a boa medição e administração de seu tempo, pela Poiésis, possibilita a supressão de seus infortúnios e dos males da modernidade em um decurso excelente.

As lições ministradas pela Paidéia Poética na cidade parisiense, para mensuração e domesticação do Tempo Profano, permite como na urbe carioca, a eliminação dos desassossegos da alma e das intempéries características da modernidade, com a oferta da supressão simbólica da angustiante certeza da finitude que acompanha o Homem desde os primórdios, posto que ao regular os ponteiros a partir do Cômputo Celestial representativo do Tempo Sagrado nas polis ideais, os leitores alcançam, nas estações repletas de abundância de toda sorte, as primícias dos frutos em todos os âmbitos de sua vida, o que simboliza a conquista do Sublime, em um devir regenerado, a cada feitura anual de almanaque. É, pois, nos doze meses patronados pelas Horas ou pelos mensageiros do divino nos almanaques, que se tem a imagem atualizada, nos calendários, das figuras representativas do medidor sagrado do tempo, com a elucidação de Commelin, que aponta tais divindades antigas representadas pelos modernos com asas de boboletas, além de serem acompanhadas por Têmis e trazer nas mãos quadrantes, relógios e outros emblemas indicativos de suas prerrogativas concernentes à acelerada passagem do tempo ${ }^{101}$. Ora, é na modernização das deusas por meio da representação dos relógios, dos quadros para mensuração do tempo, bem como do misticismo-poético assegurador de boa ventura, que os leitores podem valer-se de tais atribuições para regular o curso de sua vida com a excelência da inexorabilidade fantástica do Tempo Sagrado que, por sua vez, é gerador de uma restauração eterna do Belo pela tessitura anual de almanaque. É na feitura infindável da nova realidade salvadora do Caos moderno, que as festas móveis e fixas, como na cidade parisiense, são computadas para comemoração do Sagrado, cujos banquetes fartos dos frutos de cada estação, para deleite dos leitores, representam a Fortuna do alcance do Sublime nas cidades excelentes.

101

. Commelin, p. 82. 
Considerando o caráter místico-poético da computação do decurso nas cidades excelentes, observa-se a salvação da quantificação moderna do tempo, com seus males, pela Poiésis, posto que ao nomear a matéria caótica pela mimeses libertadora, engendra-se um devir absoluto em que a passagem inexorável é transformada em simultaneidade celestial entre o Passado, o Presente e o Futuro como alcance do Sublime. É no ato criador anual que se nota a consagração do Tempo Sagrado livre dos grilhões da pura computação da modernidade, apenas como contagem da extensão do decurso, tecendo de maneira infindável uma Totalidade Cósmico-Poética em que o Divino é reinventado a cada feitura do Belo, remetendo à Teogonia hesiódica que, segundo Torrano, é tecida com a proposição de que cada deus e cada acontecimento numinoso, de acordo com a cosmovisão da obra, é a representação do Universo como múltiplas e inumeráveis manifestações do Divino ${ }^{102}$, o que reforça a leitura do sagrado nas cidades excelentes como a própria representação do Supremo na tessitura de cada sessão com seus diversos emissários do divino, a tradução da realidade moderna e das almanaquias que permitem sonhar com o melhor dos mundos possíveis.

É pelo canto do flâneur-poeta em harmonia com as badaladas do cômputo celestial, que o Tempo Ideal é alçando nas urbes perfeitas, Rio de Janeiro e Paris, como se o ato de ajustar os relógios da vida com o horário sagrado, permitisse o próprio alcance do decurso que não se esvai, mas que permite a conquista do Belo perene nas páginas de almanaque repletas de poeticidade.

Tendo em vista o decurso maravilhoso no microcosmo místico-poético de almanaque, assinala-se ainda a relevância dos calendários como elucidação da mensuração regeneradora do tempo, pela Poiésis, que transforma infinitamente o Feio da modernidade em Belo para deleite e cura da visão turva dos leitores.

É na contagem excelente do devir nas urbes ideais que a Paidéia Poética exerce a função de orientadora no que concerne à origem de tais sistemas de divisão do tempo, valendo-se de uma súmula explicativa, por meio de um texto assaz aclarador intitulado História do Calendário do Almanaque Brasileiro Garnier para o ano de 1904, rememorando a antiguidade romana. A pedagogia para o Belo incia com a informação de que os Romanos chamavam calendário o cômputo ou o registro dos dias do ano, cujo vocábulo, do latim calendarium, é proveniente da palavra latina calendae ou calendas, sendo calendae derivação do verbo calare, que significa chamar. Prossegue com a menção de que a primeira unidade de tempo que o homem teve para mensuração do decurso foi o giro aparente do sol ao redor da 102 . Hesíodo. Teogonia, pp.84-85. 
Terra, que foi chamado, em português, dia, a duração desse possível movimento, sob a perpectiva astronômica, ao passo que em sentido físico a palavra dia correspondia ao período da elevação do astro acima do horizonte, indicação apenas da metade da permanência de tal curso. Ainda deram o nome de nox, em português, noite, ao período em que o sol, resguardando-se no ocaso, mantinha-se abaixo do horizonte.

\section{foi 0 gyro apparente a 0 sol ao redor da Terra. Cha lia-a duração do tempo d'esse supposto movimento , pois em sentido physico a palavra dia correspon Sol acima do horizonte, o que representa a $\mathrm{m}$ se movimento. \\ portugueznoite - ao periodo em que o Sol, occultas abaixo do horizonte. \\ e tempo foi daúa pelo movimento da Lua ao res em 29 dias e meio. D'ahi o mez - em latim mensi contava-se de lua nova a lua nova. 0 pontifex do novilunio e annunciava ao povo, que para e ), segundo lemos em Macrobio.}


A didática para alcance do Sublime no melhor dos mundos possíveis, deveras esclarecedora, perdura na elucidação da segunda unidade de tempo oriunda do movimento da lua ao redor da Terra, perfazendo o total de vinte e nove dias e meio, o que dá origem ao mês, do latim mensis, que era contado entre os Romanos de lua nova a lua nova. Nessa perspectiva, o pontifex minor observava a hora precisa do noviluno e divulgava ao povo, cuja atividade dava-lhe o nome de calare, segundo o macróbio. A terceira unidade é apresentada como advinda da observação, já mais aperfeiçoada, da posição da Terra em relação ao sol, que se repetia ao fim de 365 dias, 5 horas, 48 minutos e 47,8 segundos. Para mensuração exata do decurso, tais práticas traziam dificuldades, que somente após cálculos e trabalhos da ciência puderam ser definitivamente suplantadas.

A Paidéia Poética segue no cultivo dos leitores com a informação de que o primeiro rei de Roma constituiu o calendário romano composto por dez meses, sendo o primo mês consagrado ao deus Marte, soberano patrono de Roma, em latim Mars, divindade da guerra, daí o nome Martius denominar o mês de março; o segundo mês recebeu o nome de uma das estações mais favoráveis, Aprilis, do verbo aperire, abrir, posto que neste mês, abril, a terra abre-se em rebentos e flores, belo prenúncio da primavera; o terceiro foi nomeado por Romulo de Maias, dedicado aos majores e anciãos que representavam a maturidade e o conselho indispensável ao governo supremo dos Estados; o quarto consagrado à mocidade, recebendo o nome de Junius ou Juniores, indicativo dos jovens, a força e a esperança da Pátria; os subsequentes seguiram a denominação numérica em questão, o quinto chamado de Quintilis, o sexto de Sextilis, o sétimo de September, o oitavo de October, o nono de November, e o décimo e último de December.

Como tal calendário apresentava-se deficitário, o segundo rei de Roma, Numa Pompilio, reforma-o e lhe acrescenta dois meses, o Jannarius, consagrado ao deus Janus, divindade italiana bastante notória por suas muitas representações nas primeiras moedas romanas, de face bifronte, simbolizando o passado e o futuro, sendo o deus da paz e da civilização, características que também elucidavam o governo do soberano, visto que preferia a paz em detrimento da guerra, e o segundo, Februarius, deus das purificações, também divindade itálica, o que motivou a denominação de mês das abluções. Fato relevante concernente à reforma do calendário por Numa, com o acréscimo dos dois meses, é não os ter colocado no fim, mas no princípio, caracterizando-os como o primeiro e o segundo mês do ano. Além da ampliação, também alterou a ordem dos meses, mas manteve suas 
denominações. Destarte, o quinto mês, Quintilis, passou a constituir o sétimo, o sexto, Sextilis, o oitavo, e assim por diante.

Os leitores dos almanaques têm a informação de que, em seguida a tal período, os Romanos, após a morte de Julio Cesar, mudaram o nome do mês em que ele nasceu, Quintilis, para Julius, que corresponde ao mês de julho. Ainda são instruídos com a menção de que no Reinado do Imperador Augusto o senado, após a vitória de Actium, mudou o nome do mês, Sextilis, para o deste imperador, Augustus, que denomina o mês de agosto, e com o dado de que o calendário da idade moderna segue as mesmas denominações dos antigos Romanos.

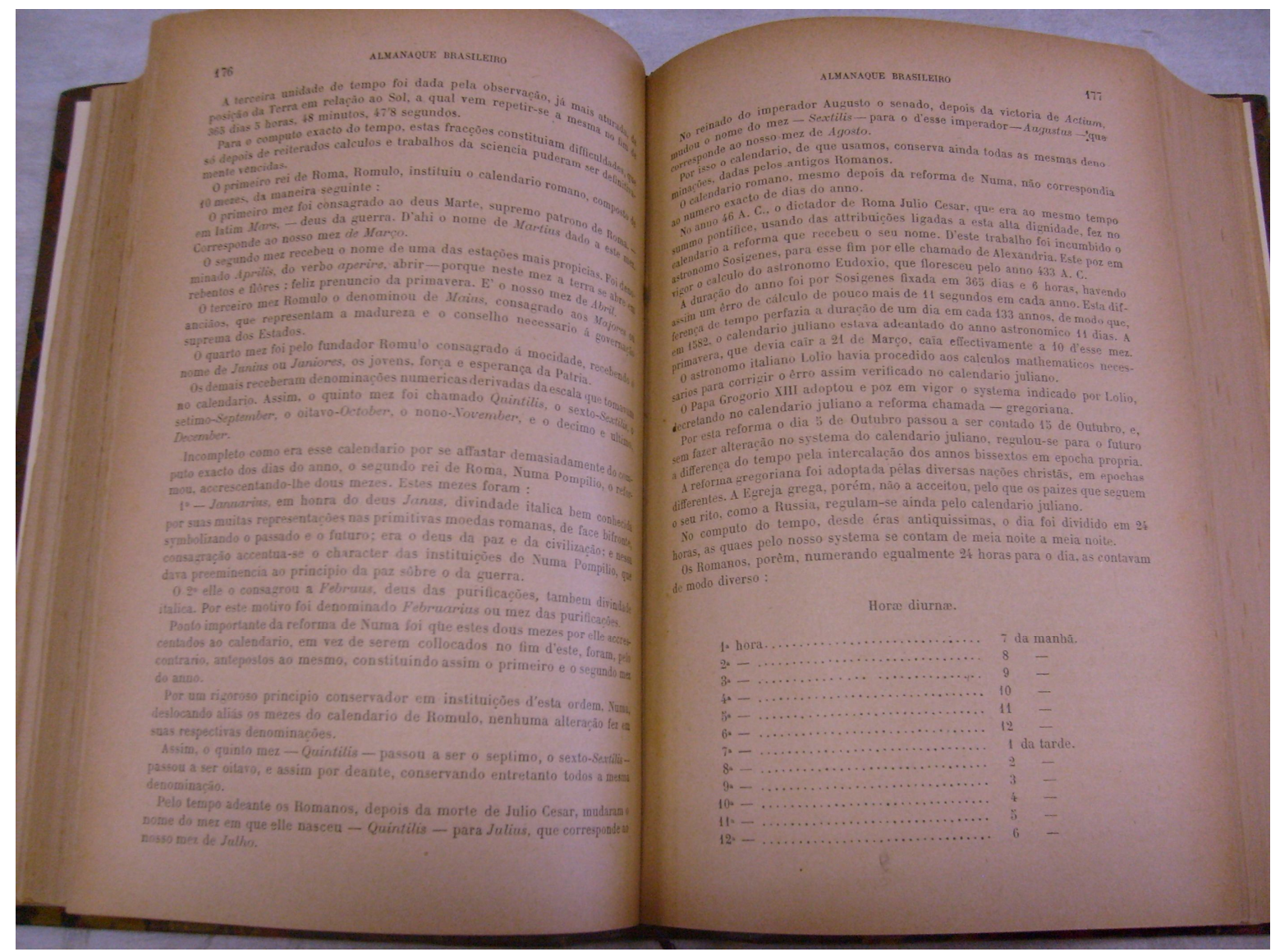

A Paidéia Poética perdura na orientação dos leitores ao apontar que mesmo após a reforma de Numa, o calendário não correspondia ao número exato de dias, e que no ano $46 \mathrm{~A}$. C., o ditador de Roma Julio Cesar, que também era sumo pontífice, utiliza-se de suas prerrogativas para batizar a Reforma com seu nome. Para essa tarefa foi incumbido o astrônomo Sosigenes, que a nomeou Alexandria, utilizando-se do cálculo do astrônomo Eudoxio, que despertou pelo ano de 433 A. C. Então, a duração do ano foi por Sosigenes 
estabelecida em 365 dias e 6 horas, o que gerou um erro de cálculo em pouco mais de 11 segundos em cada ano, cuja diferença de tempo apontada perfazia a duração de um dia em cada 133 anos, de maneira que, em 1582, o calendário juliano estava adiantado do ano astronômico 11 dias, o que fazia com que a primavera, que deveria iniciar em 21 de março, começasse efetivamente em 10 do mesmo mês. Diante disso, o astrônomo italiano Lolio trabalha com cálculos matemáticos a fim de reparar de tal erro.

Mediante a correção, o Papa Gregorio XIII adota e põe em vigor o sistema de Lolio, o que determina no calendário juliano a reforma intitulada, gregoriana.

Em decorrência de tal reforma o dia 5 de outubro passou a ser contado aos 15 do mesmo mês, o que ainda gerou, sem alterar o sistema do calendário juliano, a regulação para o futuro da diferença do tempo para a intercalação dos anos bissextos em época própria.

A pedagogia para aquisição do Tempo Sagrado ainda informa que a reforma gregoriana foi adotada pelas diversas nações cristãs, em épocas distintas, e que não foi aceita pela igreja grega, cujos países que seguem o seu rito, como a Rússia, regem o decurso pelo calendário juliano.

Tal lição para conhecimento e boa mensuração do devir aponta a referência de que, desde os antigos, o tempo foi dividido em 24 horas, que no sistema moderno contam-se da meia noite a meia noite, no entanto, os Romanos enumeravam-nas igualmente em 24 horas, mas as computavam de maneira diversa, como para a primeira hora do dia a eleição das 7 horas, para a segunda as 8 horas, para a subsequente as 9 horas, e assim sucessivamente, o que é elucidado no texto de modo bastante aclarador. A Paidéia Poética ainda aponta a computação feita no horário noturno, Horae nocturnae, o que explicita a $1^{\mathrm{a}}$ hora como $h$. noctis correspondente às 7 horas da tarde, a $2^{a}$ hora equivalente às 8 horas da noite, e assim sucessivamente. A pedagogia poética para contagem do tempo prossegue com a menção de que foi a partir da observação das fases da Lua ou dos sete planetas antigos que se produziu a subdivisão do mês em semanas - septimana, o que a Igreja designou como o primeiro dia de tal organização temporal, o dominica dies, dia do Senhor, domingo; o segundo - feria secunda, segunda-feira; o terceiro - feria tertia, terça-feira; o quarto - feria quarta, quartafeira; o quinto - feria quinta, quinta-feira; o sexto - feria sexta, sexta-feira; o sétimo sabbatus, sábado; ainda aponta a informação que Portugal manteve tal nomeação.

A lição poética para cômputo do decurso no melhor dos mundos possíveis perdura com o dado concernente à manutenção, pelos Franceses, Italianos e Espanhóis, dos dias da semana com a denominação de origem pagã, o que os primeiros chamaram de segunda-feira - lundi, 
Lunae dies, dia da Lua; terça-feira - mardi, Martis dies, dia de Marte; quarta-feira - mercredi, Mercurii dies, dia de Mercúrio; quinta-feira - jeudi, Jovis dies, dia de Júpiter; sexta-feira vendredi, Veneris dies; dia de Vênus; sábado - samedi, Saturne dies, dia de Saturno; exceto o domingo, que conservou a denominação dada ao dia do descanço, dimanche - Dominica dies, dia do Senhor; os subsequentes nomearam domingo - domenica; segunda-feira - lunedi; terçafeira - martedi; quarta-feira - mercoledi; quinta-feira - giovedi; sexta-feira - venerdi; sábado sabato; e os terceiros designaram domingo - domingo; segunda-feira - lunes, terça-feira martes, quarta-feira - miercoles; quinta-feira - jueves; sexta-feira - viernes; sábado - sábado. Já os Ingleses e Alemães, denominaram o domingo - sunday, sonntag, dia do Sol, povos que

substituíram em seu calendário os nomes dos deuses pagãos Marte, Mercúrio, Júpiter e Vênus, pelos deuses da Mitologia escandinávica, Tys, Odin, Thorr, Vria; o que deu origem aos dias da semana no calendário inglês como, domingo sunday; segunda-feira - monday; 
terça-feira - tuesday; quarta-feira - wednesday, quinta-feria - thursday; sexta-feira - friday; sábado - saturday; e no alemão, domingo - sonntag; segunda-feira - montag; terça-feira dienstag; quarta-feira - mitwoch; quinta-feira - donnerstag; sexta-feira - freitag; sábado samstag.

Ora, é pela Paidéia Poética que os leitores são cultivados para a mensuração poética do tempo nas cidades excelentes, Paris e Rio de Janeiro, que ao tecerem seus calendários de forma diferenciada, - a primeira considerando os deuses de origem pagã, exceto domingo - o dia do Senhor, e a segunda adotando a designação da Igreja - fiam o véu, cujo tecido é proveninte do sagrado oriundo da mescla do eclesiástico e do paganismo, que encobre o microcosmo místico-poético de almanaque, sítio onde, a harmonia procedente da miscelânea de representantes do universo do Divino, elucida o resgate da miticidade perdida em meio à ratio moderna que, por sua vez, suprime a liberdade do sonhar com o melhor dos mundos possíveis. É, pois, na feitura anual da nova Criação, pela Poiésis, com o material de engendro na mitologia escandinávica, na observação da Lua e nos sete planetas, que se estetiza o mundo moderno para cura de seus males, a fim de que o resgate da contemplação do Belo conduza ao alcance do Sublime na Terra sem Males de almanaque.

É pela Paidéia Poética que o flâneur-poeta leciona a arte de tornar o Tempo Profano em Sagrado, posto que ao retomar os antigos presentifica um passado de deuses e de heróis que salva os leitores da ratio e das mazelas modernas que, por sua vez, encobrem o decurso revelador do Sublime. É o ato de rememorar, ou o próprio cantar do aedo, que atualiza a idade de ouro sem males, buscando em um pretérito repleto de miticidade e poeticidade a verdadeira beleza do mundo, tendo na imagem inicial da história do calendário, a primeira unidade de medida do tempo, a atualização do aprendizado metafórico do saber olhar diretamente para o sol, como aquisição do Belo. Tal conquista dá-se por meio do movimento do astro ao redor da Terra, lição que é retomada também na modernidade, pela tarefa já mencionada, que ensina os leitores a ajustarem o relógio a partir sol. É, pois, na contemplação dos astros que o homem antigo, citando novamente Commelin (1997, p.91), abria caminho para a imortalidade, adquiria honrarias indefectíveis e adentrava na morada dos deuses, o que se observa no texto analisado como pedagogia para supressão da finitude nas cidades excelentes, na glória perene das virtudes conquistadas pelos leitores ou heróis do cotidiano e na própria atualização da mansão das divindades rebaixada, ao chão de almanaque, na modernidade. Ora, é o ato de dirigir-se aos astros, como na recordação da segunda unidade de tempo dos Romanos, o giro da lua ao redor da Terra, que se salienta a importância do olhar para o espaço sideral, tendo na 
simbologia da abertura, em consonância com o caráter místico-poético dos almanaques, a conquista, pela Poiésis, do próprio Divino, como elucidação da cura dos males do mundo sensível, ou da modernidade.

O resgate do Tempo Sagrado, pela rememoração dos antigos, faz com que a tessitura das cidades ideais encontre material, para seu acabamento, no decurso fiado e protegido pelos astros e deuses patronos dos primórdios, atualizados na imagem dos santos, dos astros, dos signos, dos astrólogos, das diversas práticas místicas, dos almanaques, garantindo que a massa caótica da modernidade seja trabalhada para ordenação geradora do Belo, engendrando um decurso elucidativo da poeticidade que permite sonhar com a verdadeira idade de ouro em tal microcosmo místico-poético. É na retomada dos astros, como unidade de medida do tempo, pela Paidéia Poética, que o cultivo dos leitores para o excelente é realizado, posto que ao elucidar que tal mensuração necessitava de aprimoramento científico, é da mesma forma orientada como lição, já apontada, que permite o cômputo do decurso pelo sol, rebento do Bem, que salva os leitores dessa mesma cientificidade e utilitarismo modernos que encobrem o Sublime.

É na elaboração do calendário pelo primeiro rei de Roma, Rômulo, informada aos leitores, que se explana o viés sagrado de tal computação, posto que os dez meses são denominados a partir da consagração ora de deuses, ora de figuras respeitáveis da época, como o primo mês, março, dedicado à divindade da guerra Mars, o terceiro, Maias, em tributo aos anciãos que representavam a maturidade e o conselho essenciais ao governo soberano dos Estados. Tal viés divino para cômputo do tempo perdura na apresentação da reforma do calendário de Rômulo por Numa Pompilio, segundo rei de Roma, pelo acréscimo de dois meses, Jannarius, consagrado ao deus Janus e Februarius, divindade das purificações, que inserido no microcosmo místico-poético simboliza a modernização das consagrações a tais entidades, em dedicação dos dias, nos almanaques, aos santos protetores diários dos habitantes das polis harmônicas. Se o resgate da história do almanaque informa os leitores sobre a dedicação dos meses aos deuses e a pessoas prestigiadas, tem-se na consagração dos dias aos santos e também a personalidades relevantes da modernidade, como atualização dos antigos heróis, o resgate, pela Poiésis, do in illo tempore inscrito neste passado que é a própria representação do Divino, traduzido na nova Criação temporal, com seus diversos calendários, a cada feitura anual. É, pois, na pedagogia para aprendizado da boa contagem das 24 horas, dos doze meses, nos 365 dias de cada ano, que os leitores têm a garantia da boa Fortuna nas cidades excelentes, o que faz dos ponteiros de seus relógios e das 
folhas marcadoras do decurso, a segurança de uma inexorabilidade poética que os salvam do Tempo Profano para adentrar no Tempo Sagrado.

É na recuperação do Tempo Sagrado, pela Poiésis, que se observa a regeneração do decurso anual na fiação infinda dos calendários que salva os leitores do Tempo Profano, tendo nos meses, com seus dias dedicados aos santos e entes notáveis da época, a atualização do caráter mítico-sagrado dos deuses e dos heróis do mundo antigo, fazendo da computação poética do devir nas urbes ideais, a supressão da angustiante ideia e ameaça da finitude, bem como dos males da modernidade, o que pode ser observado no Almanach Hachette para o ano de 1911:

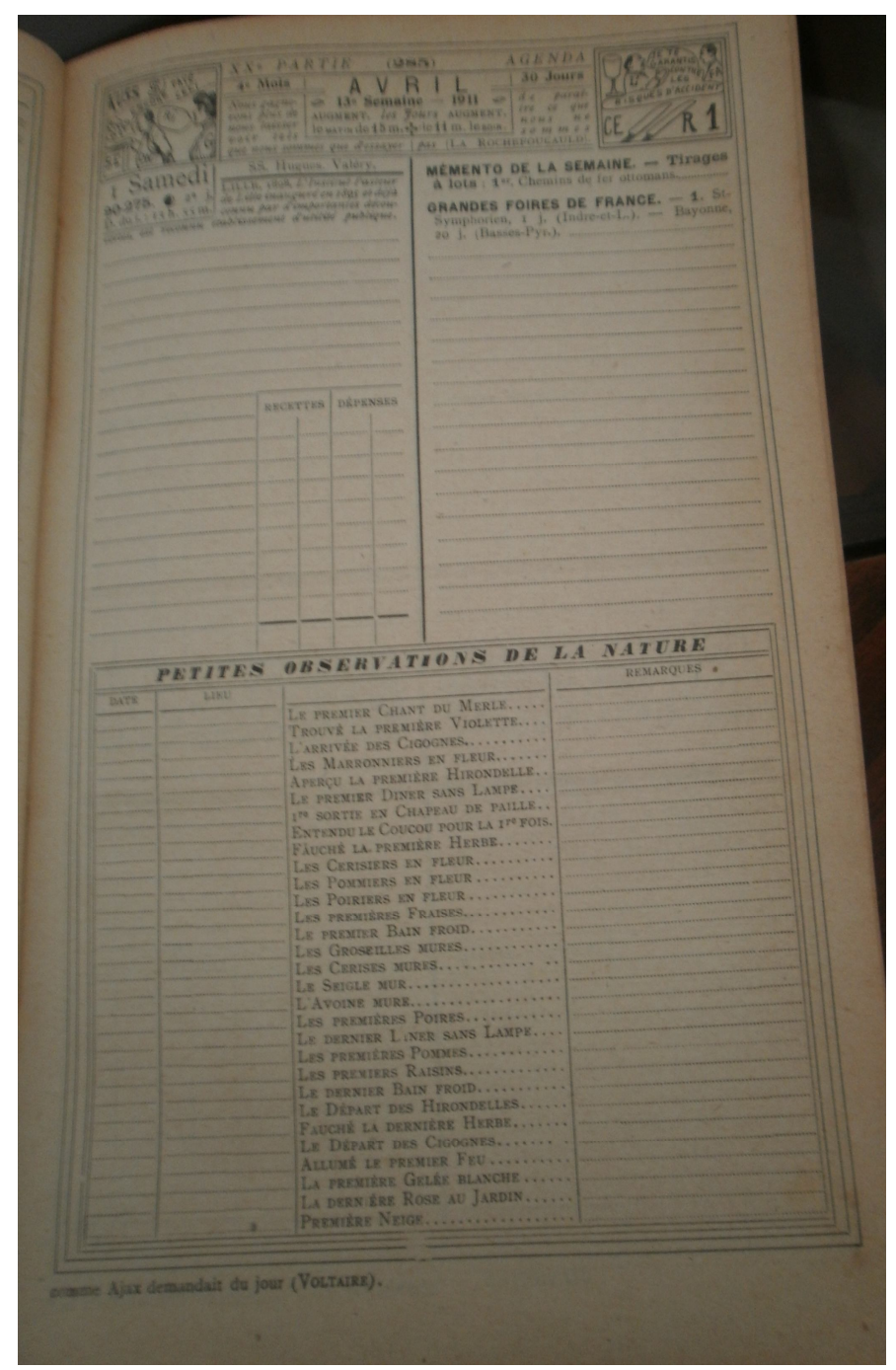

É a contagem feérica do tempo pelos calendários inseridos no microcosmo místicopoético de almanaque, cujo caráter de purificação das mazelas modernas é a atualização da consagração do mês a abluções dos antigos, que explicita uma espécie de limpeza espiritual e 
física dos habitantes para adentrarem na cidade excelente, Paris, tendo na imagem do santo guardador do primeiro sábado de abril, SS. Hugues, Valéry, a elucidação do divino patronato diário da vida no melhor dos mundos possíveis. Ora, é na computação regeneradora do decurso que os leitores são salvos do Tempo Profano, posto que o ato poético, a cada feitural anual, garante uma sorte de domesticação cíclica do devir, uma reatualização perene do ato cosmogônico, o que assegura, a cada início de ano, a certeza de que a boa Fortuna acompanha os leitores na urbe ideal, e faz da proteção periódica e eterna, haja vista o viés ciclóidetemporal dos almanaques, a renovação infinda das boas novas que suprimem as problemáticas pessoais e as representativas da modernidade. É na dedicação permanente de cada dia ao santo correspondente que se observa novamente a rememoração dos antigos, a recordação de suas práticas como faz o almanaque brasileiro ao explanar a história do calendário, visto que o cuidado diário, bem como a consagração a acontecimentos ou a pessoa notáveis, como a inauguração em 1895 do Institut Pasteur de Lille, reconhecido, por suas importantes descobertas, como estabelecimento de utilidade pública, permite a presentificação simbólica tanto do divino, quanto dos heróis míticos representados pelos atos e personalidades notórios da modernidade. Além da assistência do sagrado e da imersão dos leitores em uma espécie de atmosfera mítica com seus super-homens modernos, o que também os nutre e os fortalece com doses de heroísmo e de genialidade para enfrentar as batalhas diárias, nota-se ainda a presença da direção periódica da lua, como um retorno a segunda unidade de medida do tempo dos Romanos, já mencionada, tendo na recuperação do olhar para o astro, a atualização da necessidade da acuidade de visão para enxergar o Sublime em meio ao Caos moderno, realizando a manutenção da simbologia, em meio à ratio circundante, do poder de sua influência nas práticas cotidianas da cidade excelente, como cortar os cabelos, as unhas, plantar em dia propício, como Ideal de uma vida afortunada cujos menores hábitos são assegurados pela Ventura de tal microcosmo místico-poético.

Guias de boa Fortuna, os calendários ainda conduzem os leitores pelo Mémento de la Semaine, informando os fatos relevantes que não podem ser olvidados no decorrer da semana, como as Tirages à Lots, sorteios da loteria, como se pelo ato de anunciar, assegurasse, em tal microcosmo místico-poético, a boa Sorte nos jogos, elucidada pelo Chemins de fer ottomans, além de notificá-los a respeito das grandes feiras da França, Grandes Foires de France, que em consonância com a proteção diária dos santos, da lua, da simbologia que prediz os números certos, permite o acesso aos frutos para celebração do farto Banquete realizado diariamente no melhor dos mundos possíveis. É, pois, nas grandes feiras do Pays de Cocagne, 
no comércio de almanaquias para deleite, que os leitores podem adquirir o alimento diário tanto concernente ao espírito quanto ao físico, para assim comprar nas barracas e nos estabelecimentos repletos de poeticidade, o Belo travestido de produtos para preparação dos manjares sagrados que os nutrem e os direcionam para o alcance do Sublime. Na condução do destino dos leitores, a fim de estarem a salvo dos males da modernidade, ainda se observa o extremo zelo nas cidades excelentes, por meio da organização das despesas de seus habitantes, tendo na tabelação dos gastos a boa orientação para a supressão de quaisquer descontrole orçamentário que comprometa a vida de excelência, sendo a classificação das receitas diárias, com seus respectivos valores, a própria elucidação simbólica do cotidiano repleto de regozijo, cujos pratos deliciosos ainda compõem os abundantes Banquetes de iguarias em tal microcosmo místico-poético.

É no bom encaminhamento da vida dos leitores, no Tempo Sagrado adquirido pela domestição poético-regeneradora do decurso, a cada feitura de almanaque, que se nota nas Petites Observations de La Nature, pequenas observações da natureza, a circularidade temporal asseguradora da boa ventura na cidade excelente, o que é elucidado por meio da poeticidade inscrita nos fenômenos e atos que celebram a passagem inexorável do devir. E no ato de datar, de assinalar os sítios responsáveis por tais acontecimentos, além de reservar um espaço para ressalvas, que se tem a salvação dos leitores do utilitarismo e da ratio da modernidade - que olvida os "pequeninos nadas" reveladores do Sublime, segundo a poética bandeiriana, - em uma espécie de poema consagrado à natureza, posto que ao contemplar:

o primeiro canto do melro, encontrar a primeira violeta, a chegada das cegonhas, os castanheiros floridos, o encontro com a primeira andorinha,

o primeiro jantar sem lâmpada, a primeira saída sem chapéu de palha, o ouvir pela primeira vez o cuco, a primeira grama cortada, as cerejeiras em flor, as macierias floridas, as pereiras enfloradas, os primeiros morangos, 
o primo banho frio,

as groselhas maduras,

o trigo sazonado,

a avelã maturada,

as primeiras pêras,

o último jantar sem lume,

as primeiras maçãs,

as primeiras uvas,

o derradeiro banho frio,

a partida das andorinhas,

o aparo da última relva,

a partida das cegonhas,

o primeiro fogo aceso,

a primeira geada branca,

a derradeira rosa no jardim,

a primeira neve.

têm-se a cura da cegueira que encobre a verdadeira beleza do mundo, na caotização moderna, pela poética de almanaque. É, pois, na recuperação do hábito de observar as pequenas manisfestações da natureza, como sinônimo dos grandes alumbramentos bandeirianos, que os leitores reconquistam o Tempo Sagrado necessário para a contemplação dos belos episódios naturais apagados pela concepção moderna de velocidade e de progresso, o que torna lisível o caráter cíclico do decurso pela poeticidade do primeiro canto do melro, passando por todos os feitos singelos, porém insignes, até chegar ao estágio da primeira neve, ou seja, cultivando os habitantes da polis excelente, pela Paidéia Poética, para a observação direta da natureza, em toda a sua grandeza distribuída nas estações - como na imagem platônica do sol engendro do Bem -, a fim de enxergar o Belo suprimido pelos males da modernidade, mas renovado ciclicamente na tessitura anual de almanaque.

É no ato de recordar os primórdios, tanto pela história do calendário no almanaque brasileiro, quanto pelo emprego de práticas antigas no almanaque francês, que a Poiésis é recuperada em meio ao seu aviltamento na modernidade, retomando a sua magnitude ao traduzi-la como Paidéia Poética tecedora do Sublime, rememorando o seu caráter singular na antiguidade de cultivar os cidadãos para o Belo, o que faz das cidades excelentes Paris e Rio de Janeiro palco para os espetáculos de estetização do mundo, cujos atos são representados, 
nas sessões de almanaque, como mimeses salvadora da realidade desordenada que cega os leitores para o Divino.

Considerando a regeneração cíclica infinda do decurso nos almanaques, como salvação do Tempo Profano que faz o Belo esvair-se com sua inexorabilidade, vira-se a folha do calendário do Almanaque Brasileiro Garnier para o ano de 1911, cujo mês eleito, fevereiro, remete ao simbolismo da purificação dos antigos Romanos, apresentando também a dedicação de cada dia ao santo como atualização da consagração ao deus Februarius, recuperando, dessa maneira, o Tempo Sagrado portador do devir curativo dos males da modernidade.

É, pois, na rememoração das práticas antigas, que o almanaque brasileiro, como o francês, também elege um santo para cada dia do mês, como os S. Cesario, S. Torquato, S. Leandro, S. Romão, fazendo de tal dedicação a própria presentificação do sagrado na urbe excelente, tendo ainda na simbologia do deus da ablução, Februarius, o cotejo com uma espécie de modernização do conceito de purificação de outrora, posto que tanto na Festa da Nossa Senhora da Purificação da Candelária que acontece aos dois de fevereiro, quanto no período da Quaresma que tem início no primeiro dia após o carnaval, tem-se a ideia de um período destinado à reflexão, à mudança de vida, à limpeza dos pecados, à expurgação dos males da modernidade, haja vista a função da Poiéisis, o que reforça o viés místico-poético de tais livros herméticos, tendo no patronado dos santos e nas outras manifestações do universo do sagrado, a segurança diária provedora da vida afortunada na cidade do melhor dos mundos possíveis.

Se a rememoração dos antigos presentifica o sagrado, bem como purifica o caos moderno por uma espécie de ordenação regeneradora, tem-se na feitura anual dos almanaques, com seus calendários, o cessar do ano findo para adentrar em uma nova era, a Criação, o Ano Novo expurgado de todos os seus males, tendo a Poiésis, o papel de dar vida incessantemente ao ato primeiro da cosmogonia nas cidades excelentes, fazendo do ato poético ininterrupto a recuperação do paraíso perdido reconquistado no Sublime das cidades excelentes. É, pois, ao flanar simbolicamente pelas urbes ideais que os leitores têm no início de cada ano a conquista de uma nova vida, sendo actantes do ato criador, tendo na regeneração - do passado de infortúnios que foi encerrado e ficou para trás, do presente curado de suas problemáticas como sinônimo da modernidade e do futuro ditoso garantido pelo prenúncio de boa Fortuna, - a conquista do Tempo Sagrado, que permite o eterno retorno do Belo, pela circularidade poética geradora de um decurso salvador do mundo sensível. 


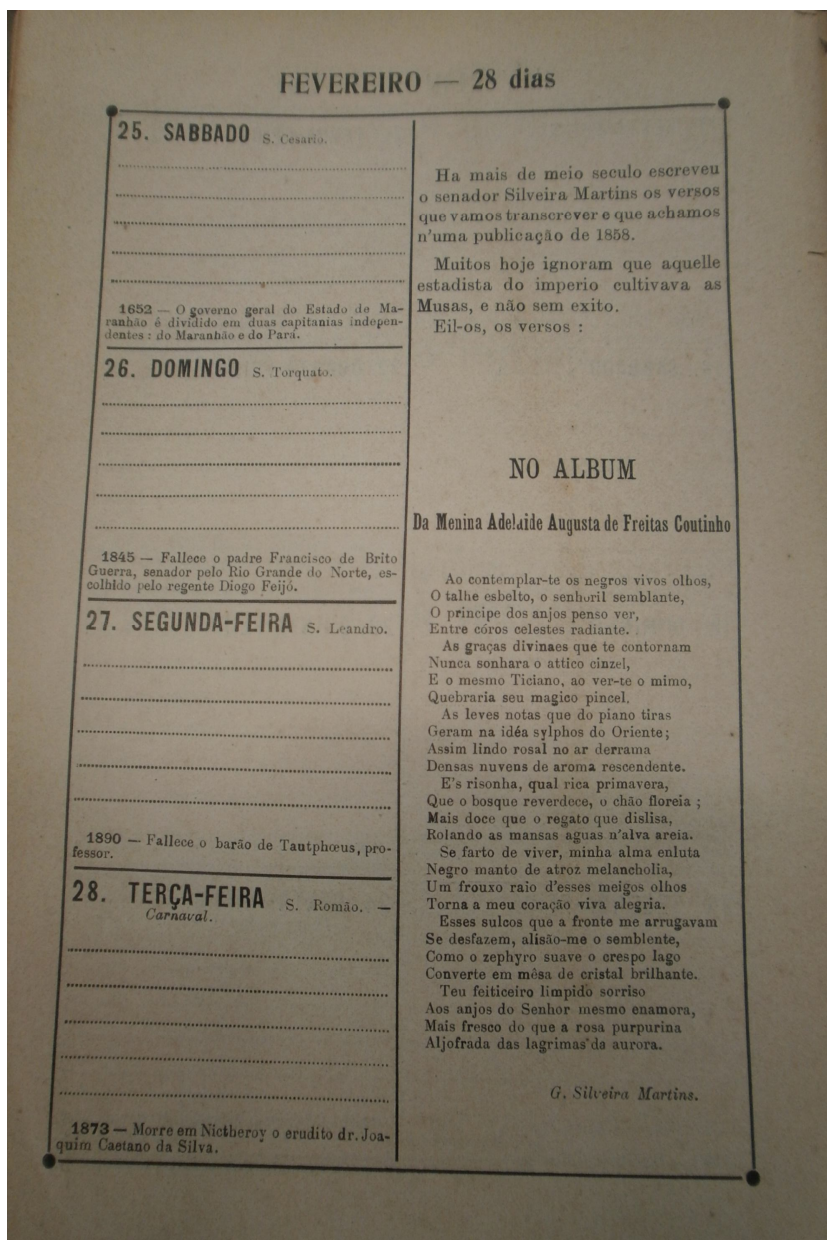

É pela Paidéia Poética que os habitantes das polis harmônicas são cultivados para a excelência, para o Tempo Ideal, tendo além da proteção periódica dos santos, também lições de savoir-faire e de savoir-vivre, o que é ministrado, como no almanaque francês, pela recordação de pessoas célebres e também de acontecimentos relevantes que orientam os leitores para uma espécie de combate das intempéries diárias com exemplos de sabedoria, o que faz renascer os heróis passados, glorificar os presentes e tecer os futuros, cujo tom de heroicidade cotidiano, como sustentação metafórica do poema épico inscrito nas páginas dos almanaques, reaviva o imaginário corrompido pelo utilitarismo e pela ratio modernos. É o ato periódico de rememorar pessoas ilustres e acontecimentos importantes da história, pela didática poético-temporal, que os leitores são educados, tendo nas informações - de que em 1652 o governo geral do Maranhão é dividido em duas capitanias independentes, no falecimento do padre Francisco de Brito em 1845, senador pelo rio Grande do Norte, no óbito do barão de Tautphoeus, professor, em 1890, na morte em Nictheroy do erudito dr. Joaquim Caetano da Silva, em 1873, - a receita diária de instrução e de arquétipos de nobreza a serem 
seguidos, que permitem atualizar, concomitantemente, os mitos representativos da excelência do princípio do mundo no microcosmo mítico-poético, a fim de suprimir os males da modernidade pelo sopro não de Zeus, mas da Poiésis que resgata a verdadeira idade de ouro.

Considerando a Poiésis tecedora do Sublime nas cidades excelentes, tem-se semelhante ao almanaque francês, o ato poético como engendro do Tempo Sagrado em que o Belo é inscrito também na singeleza do cotidiano, - olvidado na supervalorização da suntuosidade e do utilitarismo, sinônimo de progresso na modernidade, - pela rememoração do poder das musas no poema intitulado "Da Menina Adelaide Augusta de Freitas Coutinho", como resgate da verdadeira beleza do mundo que salva os leitores da falsa aparência moderna. É desse modo que o calendário da urbe carioca, como da cidade parisiense, tece o decurso pelo ato poético que assegura o alcance do Supremo periodicamente, por meio da menção de que há mais de meio século o senador Silveira Martins, em 1858, um estadista do império, cargo que, a priori, parece indicar falta de apreço em relação ao Belo, cultiva o poder das musas, o que é lisível como Paidéia Poética àqueles que se deixaram cegar pelo utilitarismo moderno. Ora, é na contemplação da menina Adelaide, pelo eu-lírico, como alcance do próprio Divino, comparada ao príncipe dos anjos em meio aos coros celestes, que diante de tamanha beleza até mesmo Ticiano quebraria seu mágico pincel, o que ainda é reforçado pelas notas que são tiradas do piano pela amada e que geram, na ideia, silfos do Oriente, cujo formoso rosal no ar despeja nuvens carregadas de aroma. É na imagem da rica primavera risonha, mais doce que o riacho, que diante do enfastio de viver, o sujeito poético encontra acalento para sua melancolia nos meigos olhos da enamorada e recupera a alegria em seu coração, o que também lhe traz rejuvenecimento, posto que os sulcos da fronte característicos da passagem dos anos são desfeitos como uma espécie de remoçar oriundo de sua bela visão, como o vento do Oeste, Zéfiro, na mitologia grega, que torna o crespo lago em mesa de cristal brilhante. Enaltece ainda sua beleza, por meio de seu feiticeiro límpido sorriso, o que lhe dá um ar tanto de mulher sedutora, quanto de jovem pueril, fazendo um jogo entre sagrado e profano, visto que até mesmo os anjos do Senhor encantam-se por tamanha graça, traduzida também pela sublime representação de que a menina Adelaide apresenta uma frescura maior que a rosa purpurina coberta pelo orvalho das lágrimas da aurora. É na mescla do épico com o lírico, que a poeticidade de almanaque salva os leitores da barbárie utilitarista moderna, o que pode ser elucidado por meio do poema do estadista, com suas imagens caracterizadoras do Belo, posto que a contemplação da amada remete ao belo, aquele que não se esvai com o decurso, mas permanece na representação do remoçar do amado, cujas marcas de expressão já não existem, 
mas são apagadas pelo verdadeiro alcance do Sublime - do amor do belo em si, e não mais dos corpos entre os amantes - pelos enamorados no melhor dos mundos possíveis. É pelo lirismo de um homem de ferro, o estadista do império, gerador do ato criador que resgata a verdadeira beleza do mundo nos dias 25 aos 28 de fevereiro, haja vista o caráter simbólico purificador do mês e a feitura regeneradora anual dos calendários, e que estão em consonância com a poética de almanaque que recupera o Sublime pela incessante tessitura do Tempo Sagrado, que se vê a possibilidade da cura, pelo cultivo das Musas, das mazelas modernas causadas pela supervalorização da ratio e da infinda produção de crescimento na realidade industrial.

É, pois, pelo ato poético que se observa, nas urbes excelentes, a conquista da nova realidade, a Criação que possibilita a ordenação do Caos moderno em Cosmo, ou microcosmo quimérico, onde os leitores alcançam um tempo de eterna felicidade a cada compra anual e leitura periódica dos livros herméticos, pelos os quais a inexorabilidade do decurso, que traz consigos os desassossegos da alma, é domesticada e regenerada nos calendários que permitem um devir repleto de boa Fortuna.

Tendo em vista a circularidade poética do decurso que salva os leitores dos infortúnios da vida moderna, consideram-se ainda os outros calendários que contribuem para a feitura do Tempo Sagrado nas polis harmônicas, o que pode ser elucidado pelos, Calendário Perpetuo, Calendário Gregoriano e Calendário Eclesiástico, cujo diálogo com a fiação do devir na urbe parisiense também se dá pelos Calendrier Perpétuel, Calendriers Républicain e Grégorien e o correpondente Année Catholique Romaine, dos quais se priveligia, para análise, a perenidade evocada pelo Calendário Perpetuo e pelo Calendrier Perpétuel.

A certeza de que o tempo marcha simbolicamente sob o ritmo do horário excelente e a quantidade significativa de cômputos em tal sítio maravilhoso remetem à análise do Calendrier Perpétuel do Almanach Hachette para o ano de 1911, que pela própria nomeação garante a eterna possibilidade de mensuração do decurso, o que em consonância com o microcosmo místico-poético, permite a regeneração infinita do tempo, traduzida em um devir sagrado infindável e renovador da boa Ventura dos habitantes da República das delícias parisiense. 


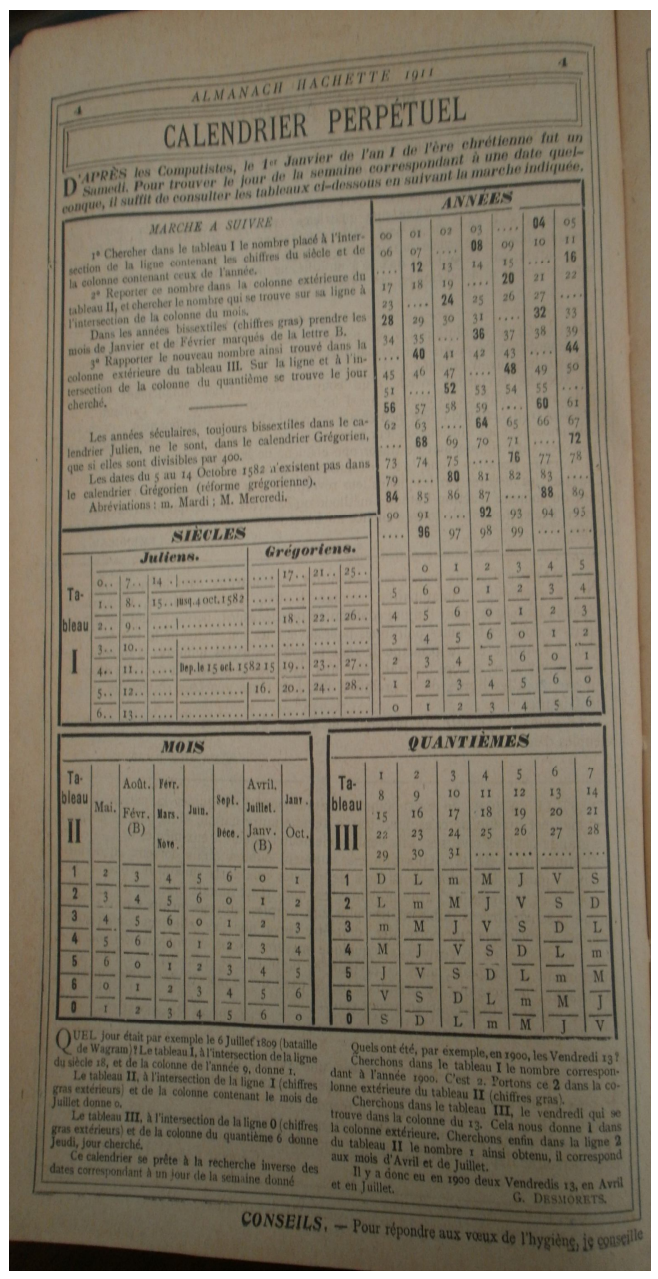

É pela Paidéia Poética que os leitores são cultivados para a computação maravilhosa do tempo na cidade excelente, tendo a partir do vocábulo perpétuel - perpétuo, e das lições ministradas, o alcance do Tempo Sagrado que não se esvai e leva consigo o Belo, mas permanece eternamente na poeticidade do melhor dos mundos possíveis. É nesse viés que a pedagogia para a contagem do tempo Ideal é aplicada, iniciando pela menção de que, segundo os calendaristas, o primeiro de janeiro do ano I da era cristã foi um sábado, para que os leitores possam, por meio do exemplo, apreender a encontrar o dia da semana correspondente a qualquer data, pela consulta dos quadros elucidados, seguindo a orientação indicada. Para tal mensuração poética, considerando o microcosmo quimérico de almanaque, tem-se uma espécie de etapas a ser seguida a fim encontrar a perpétua felicidade na idade de ouro atualizada, elencadas da seguinte maneira: $1^{\mathrm{a}}$. Encontrar no quadro I o número colocado na intersecção da linha contendo os números do século e da coluna contendo aqueles do ano; $2^{\mathrm{a}}$. Colocar este número na coluna exterior do quadro II e procurar o número que se encontra 
sobre a linha de intersecção da coluna do mês, Nos anos bissextos (números em negrito) pegar os meses de janeiro e de fevereiro marcados com a letra B; $3^{\mathrm{a}}$. Inserir o novo número, assim encontrado, na coluna exterior do quadro III. Sobre a linha e na intersecção da coluna do dia encontra-se o dia procurado. Após as três fases, a instrução para o Belo perdura com a indicação dos anos seculares, sempre bissextos no calendário Juliano, mas não o são, no calendário Gregoriano, que são divisíveis por 400, também na explanação de que as datas de 5 a 14 de Outubro, de 1582, não existem no calendário Gregoriano (reforma gregoriana). Com o intuito de atingir os leitores de modo claro, a didática é assaz eficaz ao apresentar questões e indicações para encontrar sua resposta, como se estivesse examinando o aprendizado para o excelente, tendo nas indagações - Quel jour était par exemple le 6 juillet 1809 (bataille de Wagram) ?, Quels ont été, par exemple, en 1900, les Vendredi 13?; Qual dia era, por exemplo, 6 de julho de 1809? (batalha de Wagram) e Quais foram, por exemplo, em 1900, as sextasfeiras 13?, - o teste necessário para avaliar sua metodologia.

É dessa maneira que a Paidéia Poética educa os leitores para a computação do Tempo Sagrado, perpétuo, que não segue a inexorabilidade do Tempo Profano, mas é domado nos vários quadros, pela poeticidade regeneradora do decurso feliz, na cidade ideal, como uma espécie de retorno à idade de ouro, sob o reinado de Cronos que, segundo Commelin, é o secundogênito de Urano e da antiga Vesta, ou do Céu e da Terra, que após ter destronado seu pai, recebeu de seu irmão mais velho, Titã, a graça de reinar em seu lugar, sob a condição de que toda a sua posteridade masculina deveria perecer, a fim de que a sucessão fosse reservada aos filhos do primogênito. O que se segue ao pacto entre os irmãos é a união de Cronos e Réia, com quem teve vários filhos, que eram devorados avidamente a cada nascimento, conforme o acerto. Por saber que, em um dado momento, também seria destituído de seu trono por um de seus filhos, ordenava a sua esposa que lhe entregasse todos os recémnascidos. Apesar da voracidade com que abocanhava os filhos, Réia ainda consegue salvar Júpiter, que, ao crescer, luta com o pai e o vence, e da mesma maneira que tratara seu genitor, Urano, ao destroná-lo, também é expulso do Céu. Não somente Júpiter foi livrado da fúria de Cronos, mas Reia conseguiu ainda salvar com a mesma perspicácia, Netuno e Plutão, e uma filha, Juno, irmã gêmea e esposa de Júpiter. Além dos mencionados, há aqueles que acrescentam Vesta, deusa do fogo, e Ceres, divindade das colheitas, o que se amplia com o grande número de filhos que teve com várias mulheres, como centauro Quíron da ninfa Filira, dentre outras. Diz-se ainda que após ter sido destronado por seu filho Júpiter e diminuído a condição de simples mortal, refugiou-se na Itália, no Lácio, sítio em que reuniu homens 
valentes dispersados nas montanhas e lhes apresentou leis, o que constituiu seu reinado, a idade de ouro, posto que seus plácidos súditos eram governados com brandura. É, pois, nesse tempo, cuja equidade de condições foi recobrada, que nenhum homem estava a serviço do outro, ninguém havia nada particular, visto que tudo era comum, como se todos tivessem recebido a mesma herança ${ }^{103}$.

É, pois, na feitura anual e regeneradora, pela Poiésis, do microcosmo excelente, em consonância com as formas contíguas de mensuração do decurso, que se observa a atualização do mito de Cronos, posto que é vencido pela tessitura infinda do Tempo Sagrado que, por sua vez, o domestica e vence sua voracidade insaciável pelo inexorável, em seus diversos calendários, tendo no Perpétuo, a consagração da sucessão de seu trono pelo devir cíclicopoético renovador das boas novas na cidade ideal. Ora, por ser vencido e não poder devorar os anos, o que representa a passagem do tempo e o fenecimento do Belo, é expulso do Céu para justamente cair no Lácio, travestido de cidade ideal, Paris, onde constitui seu reinado, a idade de ouro, como salvação dos males da modernidade, em que seus habitantes vivem um tempo de equidade, nenhum a serviço do outro e possuidor de nada privado, mas com a abundância comum de almanaquias, caracterizadora da vida afortunada, recebida na conquista do melhor dos mundos possíveis. A idade de ouro de almanaque vence Cronos pela fiação interminável do Tempo Sagrado, como se o amordaçasse para jamais devorar os anos dos leitores e a beleza que transforma em um eterno devir de efemeridade, no entanto, ao domesticá-lo, pelo método dos computistas, toma sua doçura tardia mesclada à poeticidade, para reger os habitantes da polis excelente pela governabilidade quimérica, que constitui a Política de sonhos, curativa e denunciatória dos problemas característicos do mundo moderno.

É do mesmo modo que a computação poética do decurso é realizada no Almanaque Brasileiro Garnier também para o ano de 1911, com o Calendario Perpetuo, tendo na tessitura anual da nova realidade, do engendro que ordena o Caos moderno, o Tempo Sagrado que produz a perenidade regeneradora da boa Ventura na cidade ideal, Rio de Janeiro, que em conformidade com a urbe parisiense, contribui para a edificação e acabamento do melhor dos mundos possíveis. 


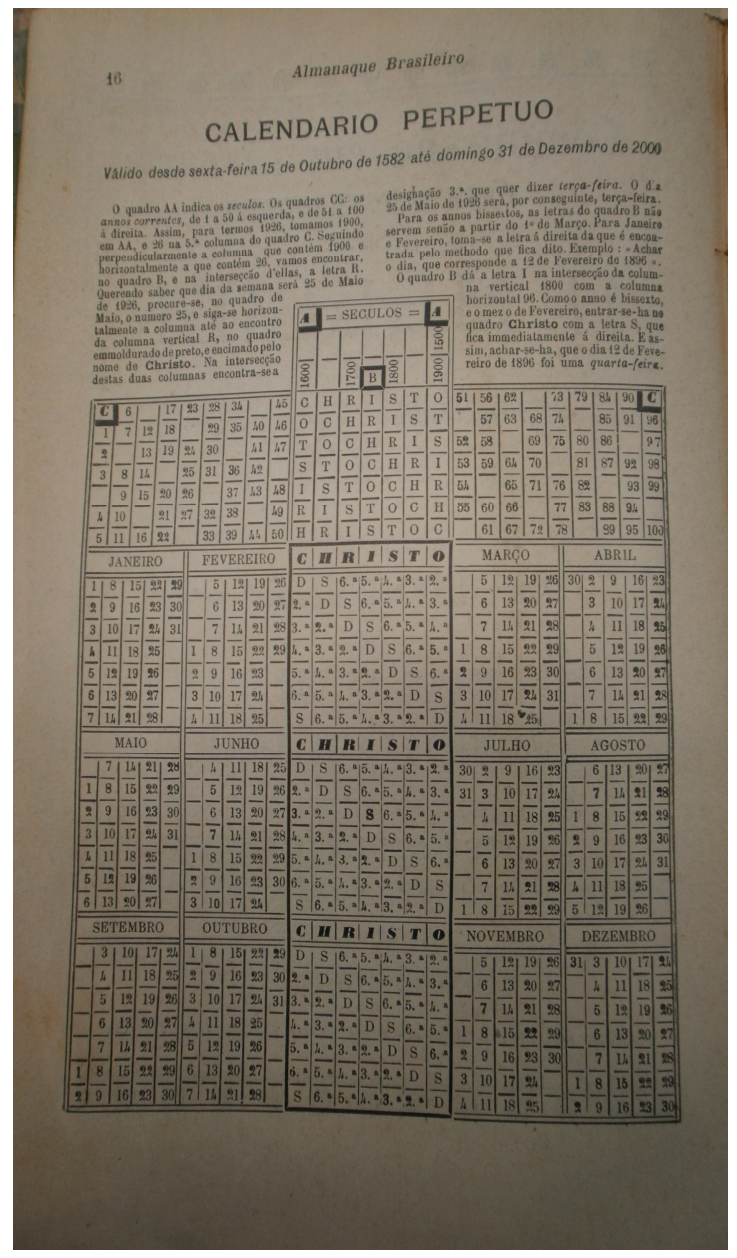

Semelhante à contagem do tempo na urbe parisiense, o decurso na polis carioca também é computado pela Paidéia Poética que instrui os leitores para o Belo que, por sua vez, é perenizado nos quadros que garantem a eterna boa Ventura de um tempo cíclico-regenerador, - apesar de delimitar o período de mensuração entre o dia 15 de outubro, sexta-feira, de 1582 até domingo, 31 de dezembro, de 2000, quiçá por considerar um dos mais conhecidos prognósticos de término do mundo em tal data - haja vista o próprio vocábulo "perpétuo", do calendário, que reforça o seu caráter de eternização de uma inexorabilidade inscrita no Sublime que renasce a cada feitura de almanaque. É pela pedagogia para o alcance do Belo na cidade ideal, que seus habitantes são cultivados, o que pode ser elucidado na orientação dada para a contagem do tempo Ideal em qualquer época, como se o devir estivesse sempre controlado para o excelente, iniciando pela explanação dos quadros que compõem o calendário, como o AA que indica os séculos e o $\mathrm{CC}$ os anos correntes, sendo compostos à direita pelos números que vão de 1 a 50 e à esquerda pelos algarismos que vão de 50 a 100. 
Mediante a orientação concernente à composição dos dois quadros, a explicação prossegue com um exercício bastante aclarador para assimilação do método de eterna computação do tempo, valendo-se do ano almejado 1926, que pode ser encontrado a partir do ano $1900 \mathrm{em}$ AA, e 26 na $5^{\mathrm{a}}$ coluna do quadro $\mathrm{C}$, seguindo ainda perpendicularmente a coluna que contém 1900 e horizontalmente a que apresenta 26, descobrindo, por fim, no quadro B, e na intersecção delas, a indicação da letra R. Para melhor elucidação, a Paidéia Poética ainda acrescenta uma nova questão, encontrar o dia da semana que será 25 de maio de 1926, que pode ser solucionada procurando, no quadro de maio, o dia 25 , e seguindo horizontalmente a coluna até o encontro da coluna vertical $R$, no quadro emoldurado de preto e intitulado Christo. Na intersecção dessas duas colunas, encontra-se a designação $3^{\mathrm{a}}$., que indica terçafeira, em cuja localização inscreve-se o dia procurado, 25 de maio de 1926. Os leitores também têm orientação para contagem dos anos bissextos com a indicação de que as letras do quadro B servem para a computação apenas a partir de $1^{\circ}$ de março, já para janeiro e fevereiro toma-se a letra à direita da que é encontrada pela indicação do método. Com o intuito de atingir, de maneira eficaz, os aprendizes para a computação poética do tempo na cidade maravilhosa, a didática para o excelente finaliza com um exemplo assaz esclarecedor, semelhante ao calendário francês, seguido das indicações para a resposta, como encontrar o dia correspondente a 12 de fevereiro de 1896, que pela efetivação dos passos ministrados, chega-se à conclusão de que caiu em uma quarta-feira.

É importante salientar que a Paidéia Poética para contagem perpétua do decurso permite a initerrupta regeneração do Tempo Profano na feitura anual do Tempo Sagrado da cidade excelente, visto que pelo ato poético, a nova Criação, volta-se ao princípio do mundo, ao paraíso sem males, que tem sustentação na representação do divino pela nomeação do quadro de Christo do Calendario Perpetuo, além das outras traduções que remetem ao sacro nos almanaques, como se a terra Prometida fosse alcançada na idade de ouro asseguradora do eterno Banquete, em comemoração ao acorrentamento de Cronos, no melhor dos mundos possíveis. É o vocábulo Christo, do calendário, cujo significado remete a própria imagem de Cristo, mesclada a outras formas de interpretação do Sagrado, que garante a atualização das festas Saturnais que os Romanos celebravam em recordação à idade feliz do reinado de Cronos, mas diferente dos antigos, é presentificada na vivência do excelente nas cidades ideais Paris e Rio de Janeiro, sítios em que as festas móveis e fixas e outros festejos, com fartura de toda sorte de almanaquias, comemoram a conquista do Belo rompedor das correntes que aguilhoam não mais a deidade voraz, mas os pés dos leitores impedidos de ir ao encontro 
do Divino na modernidade enferma. Do mesmo modo que no almanaque francês, após a destituição de Cronos do trono e sua expulsão do Céu, também se refugia no Lácio metamorfoseado em cidade ideal, Rio de Janeiro, na qual representado pelo exercício dos outros intérpretes do Sagrado, constitui seu governo de eterno gozo, a idade de ouro moderna que, por sua vez, não é sucedida por nenhuma outra época, visto que a perenidade do decurso cíclico-regenerador é assegurada pela incessante feitura poética do tempo excelente como pedras que são dadas para saciar a voracidade daquele que espreita, periodicamente, nas frestas dos muros que circundam o melhor dos mundos possíveis.

É, pela Paidéia Poética, que os leitores apreendem a se proteger do sombrio Cronos atualizado pelo Tempo Profano que consome o Belo com o utilitarismo e a ideia de insaciável progresso da modernidade, transformada sua representação, segundo Commelin, de um ancião curvado em decorrência do peso dos anos, com uma foice na mão simbolizando o presidir do decurso, ou ainda, em muitos monumentos, caracterizado por um véu indicativo da nebulosidade dos tempos e da cobertura impenetrável ${ }^{104}$, em simples mortal, de uma doçura inimaginável, que pode ser elucidada pelo governo excelente dos homens brandos e virtuosos, na idade de ouro de almanaque. Ora, como Cronos não pode ordenar o mundo divino, o que é feito por seu filho e sucessor, Júpiter, após ser domesticado pela pedagogia do Belo nos almanaques, faz em tal microcosmo místico-poético o próprio engendro do Olimpo ou Empírio Terrestre pelo seu reinado, a verdadeira idade de ouro, não a da chamada Belle Époque, mas a traduzida pelo ato poético que permite a edificação da morada celeste dos habitantes das cidades ideais, em que vivem um Tempo Sagrado de eterno regozijo, livre de aflições e de deventuras. É a expulsão de Cronos do Céu, a queda não do Homem, mas da deidade, que permite um caminho inverso ao do labor e da desdita nas urbes excelentes, posto que o Tempo Sagrado, agora não mais engolido por ele, permite o alcance do Belo pela tessitura incessante do Caos em Cosmo maravilhoso, calçado de paralelepípedos de ouro em pó que transluzem a verdadeira beleza do mundo moderno ofuscada pela voracidade do utilitarismo.

É pelo alcance do Tempo Sagrado, na idade de ouro moderna, que se observa uma espécie de circularidade poética do decurso, cuja inexorabilidade, sempre regeneradora, garante a salvação dos leitores dos inúmeros desassossegos, oriundos da certeza da finitude, que atormentam o Homem desde os primórdios, o que permite, pela Paidéia Poética, a elaboração de uma pedagogia para a morte, ou seja, ensinar a arte do fenecimento para $104 \quad$. Commelin, p.11. 
conquista do Belo que não se increve no mundo sensível, mas no Sublime do melhor dos mundos possíveis.

Desse modo, o ato poético initerrupto possibilita a recuperação de um devir de incessante nascimento, em que a ameaça do perecimento é transformada em estetização do Feio para obtenção da pereneidade da beleza que não se esvai com o tempo nas cidades excelentes, onde a morte já não amedronta, posto que a eterna fiação do Tempo Sagrado garante a aquisição do Sublime inscrito no microcosmo de excelência. É, pois, na abolição simbólica da finitude que se notam nas Recettes de La Vie Pratique, Deuils, Règles et durée, receitas da vida prática, lutos, regras e duração, do Almanach Hachette para o ano de 1911, a educação para a boa morte, aquela que ensina, pela Paidéia Poética, o savoir-vivre da vida cotidiana, o apreender na morte de cada dia a natividade do Belo. A nova Criação, a cada edição de almanaque, garante um decurso regenerador que combate, na cidade ideal, os efeitos do fenecimento procedente do Tempo Profano, o que pelas regras e duração dos lutos permite o alento oriundo de ciclos de lembrança constante da pessoa amada, cujos mais longos são aclarados, pela Paidéia Poética, como aqueles que compreendem, geralmente, o da mulher três períodos: o $1^{\circ}$ do crêpe - crepe; o $2^{\circ}$ da soie noire - seda preta; o $3^{\circ}$ do demi-deuil, meioluto, além dos mais curtos que comportam apenas um período de seda preta e depois um de meio-luto. É no quadro de educação para o fenecimento, como campo de lisibilidade poética, que se nota uma espécie de ornamentação da morte, cujos diferentes tipos de tecido fornecem a roupagem necessária para a transformação do Feio em Belo, tanto pela recordação que indica uma espécie de renascimento, como pelo adornar que consiste uma finitude não mais tétrica, mas com a vestimenta da bela consternação que, doravante, no melhor dos mundos possíveis, é metamorfoseada em vida perene carregada de poeticidade.

Destarte, é no enquadramento dos lutos, como uma sorte de aprisionamento simbólico da morte, que se observa a preparação, assaz didática, para a transformação do pesar, pela Poiéisis, em dose diária de entusiasmo criador, tendo no viés cíclico do decurso na cidade maravilhosa, Paris, a conquista do Sublime curador da inexorabilidade que desfaz o Belo, sendo os tecidos indicados para o período de crepe, todas as lãs de um preto fosco: crepe de lã, crepom, sarja, cachemire, etc, o próprio embelezamento da dor que recupera, pela rememoração, o que se esvaiu com a passagem do decurso. Ora, é no aprendizado para a morte como lição para enfrentamento do Tempo Profano, que a Paidéia Poética ainda orienta sobre os tecidos para o período de seda preta; lãs pretas cintilantes, brocadas, setinadas, 
pequinesas, etc, guarnecidas de seda sem brilho, e as sedas foscas como a pele de seda ou de camurça, etc.

A pedagogia poética, que ministra uma espécie de ritual terapêutico para as dores causadas pela perda, segue na orientação a respeito dos tecidos para o meio luto, a seda preta fosca ou brilhante, veludos, lãs, etc, tons cinza e violeta, dentre outros. Prossegue na elucidação concernente à duração do luto, que é idêntica para homens e mulheres, no entanto, a do viúvo equivale a um ano (seis meses de grande luto e seis meses de meio luto); já as crianças com menos de doze anos guardam o luto sem crepe inglês, em preto e branco, em branco ou cinza, o período é facultativo para os menores de quatro anos, exceto se de pai ou de mãe, e os domésticos devem portar preto, com ou sem crepe, durante todo o luto dos patrões. Diante das lições para embelecer tal período sombrio, é importante explicitar que o crepe, tecido fino ou fita que se usa em sinal de luto, apresentam a simbologia do presentificar o fenecido por um determinado período que, por sua vez, inserido no microcosmo místicopoético de almanaque, permanece de maneira infinita na feitura anual do Tempo Sagrado. A Paidéia Poética perdura com a instrução de que no enterro os homens devem portar o casaco e a calça de tecido fosco, o colete e a gravata brancos de cambraia ou de musselina. A etiqueta poética, para celebração e alindamento simbólico do Feio, a morte, na urbe excelente, ressalta que o colete e a gravata pretos são admitidos, e que para aqueles de situação modesta o uso de toda a vestimenta pode ser substituído - exceto para os lutos de viuvez, de pai e de mãe - por uma braçadeira de crepe inglês no braço esquerdo e um crepe no chapéu, que toma toda a sua altura no período de grande luto e a sua metade no meio luto, além das luvas pretas de camurça ou de filosela; e da barra da camisa e da manga em bois durci. É por meio da menção aos menos favorecidos, como ato denunciatório das disparidades sociais na Belle Époque, explicitado pela alusão aos problemas sociais decorrentes da diminuição do salário real de 1905 a 1913, e aumento do salário nominal e do custo de vida, o primeiro insuficiente em detrimento do segundo, o que gera estado de carência e até mesmo de subalimentação em 
vastos setores operários $^{105}$ - suprimidos pela equidade entre os habitantes da polis harmônica que o processo de enfeamento do Belo, característico do mundo circundante, é erradicado pelo alcance do Sublime, por todos os indivíduos, na verdadeira idade de ouro de almanaque.

Para melhor assimilação, a Paidéia Poética finaliza com a tabelação dos períodos de luto no centro do quadro, uma espécie de resumo facilitador para o cultivo dos leitores na educação para a bela morte, acrescentando outras informações concernentes à duração e às regras do tempo determinado para a dor da perda, adicionando nos três ciclos: crepe, seda preta e meio luto, os respectivos números para cada alusivo, para sogros - 6 meses, 6 meses e 3 meses; criança - 9 meses, 3 meses, 3 meses; genros - 9 meses, 3 meses, 3 meses; avós - 3 meses, 6 meses, 3 meses; irmãos - 3 meses, 3 meses, 3 meses; cunhados - 3 meses, 3 meses, 3 meses; tios - supressão do crepe, 3 meses, 6 meses; e primo - supressão do crepe, 3 meses, 3 meses. É por meio do tabelamento dos períodos de luto, que os leitores, representados por todas as categorias citadas, têm o alento necessário para os temores decorrentes da finitude, tanto em relação a seu fim quanto daqueles que lhes são caros, como se o aprisionamento da morte em uma espécie de quantificação consoladora e regeneradora pudesse, em decorrência da Criação infinita do ato poético, recuperar o perdido na idade de ouro de almanaque, haja vista que o Tempo Profano, vencido pelo Tempo Sagrado, permite o resgate do que se esvaiu com o decurso em uma espécie de renascimento perene. Ora, é na determinação dos períodos para rememorar o perdido, como uma sorte de culto simbólico às glórias do ente falecido, que novamente se recupera a miticidade dos antigos, posto que tal ritual de celebração dos feitos daqueles que se foram tece, em consonância com o microcosmo místico-poético, a atualização da heroicidade que salva a modernidade de seus males, bem como lhe fornece a dose diária de coragem e nobreza inscrita na vida dos que partiram, como metáfora de uma epopoéia moderna que narra as proezas de homens prodigiosos e os colocam como arquétipos a ser imitados, semelhante às façanhas dos deuses e dos heróis da antiguidade.

É o ato poético, tecedor do Sublime a cada edição de almanaque, mesclado ao resgate do fenecido por meio da incessante criação nas ruas de ouro em pó da cidade excelente, que remete a República de Platão com sua alusão à imortalidade da alma, rememorando outra passagem do mito de Er em sua descida ao Hades, no momento em que as almas escolhem suas vidas e se dirigem a Láquesis que dá a cada uma o dêmon escolhido como guardião e algoz das opções feitas. Seguidamente cada alma é levada a Cloto que, pelas suas mãos e giro do fuso, confirma o destino escolhido no sorteio, e após tal realização, é dirigida ao tecido 
feito por Átropos que torna permanente o que Cloto tecera. Nesse percurso, cada alma, sem girar a cabeça para trás, chega ao pé do trono da Necessidade, e todas ao passar por tal etapa, caminham juntas para a planície do Letes, onde há um terrível calor sufocante, visto que em tal sítio não existem árvores e plantas nutridas pela terra. Ao anoitecer as almas acampam, à margem do rio Ameles, cuja água nenhum vaso armazena, sendo mister que todas a bebam com parcimônia, mas as insensatas tomam-na além da medida, e todas que a bebem olvidam-se de tudo. Após a passagem pelo rio, ao dormir, no meio da noite, ocorre um raio e um terremoto e, a partir de tal acontecimento, subitamente se percebe as almas indo para lados diferentes, dirigindo-se para o alto, a fim de renascer, brilhando como estrelas. Mas Er é impedido de beber a água, por isso não sabe de que maneira tinha voltado ao seu corpo, e de repente, ao olhar para o alto, na hora da aurora, vê-se deitado sobre a pira ${ }^{106}$.

Considerando o Mito de Er para elucidação da supressão simbólica da morte na República das delícias, observa-se que na medida em que as almas escolhem suas vidas e têm o dêmon responsável por seu destino, para seguidamente renascer como estrelas brilhantes representando a imortalidade do mundo inteligível, posto que o corpo fenece por estar inserido no mundo sensível, mas a alma jamais, traduzindo a sua existência preexistente ao homem, e permanecendo após seu perecimento - nota-se o diálogo quimérico com o Tempo Sagrado que já não possui inexorabilidade, que não consome os dias de maneira voraz, mas que caracteriza o Sublime, da polis harmônica platônica, na idade de ouro atualizada, em que o renascer é dado pela incessante criação poética, e o dêmon, guardião dos leitores, simbolizado pelos diferentes emissários do divino na urbe ideal, os santos, a figura de Cristo apontada no calendário, os signos, os astros, os astrólogos, dentre outros, como condutores e protetores da boa Fortuna no melhor dos mundos possíveis. Ora, é justamente pelo renascimento ininterrupto da nova realidade, pela ordenação poética do Caos moderno, que os leitores já não choram seus mortos na cidade excelente, posto que a transformação do Feio, pela nova vestimenta de crepe a cada feitura e leitura de almanaque, embelece os males da modernidade com a ornamentação da morte para alcance do Belo, o que faz os habitantes deste sítio maravilhoso expirar como que tomados por sono, semelhante à idade de ouro apontada por Hesíodo, embalados em sonhos de almanaquias que revivem por meio da tessitura anual de tais livros herméticos. É dessa forma que as filhas da Necessidade mencionadas na narração de Er, Cloto, Láquesis e Átropos, em consonância com o microcosmo místico-poético de almanaque, velam não apenas pela boa Ventura dos cidadãos 106. República, 621 a, b, pp. $416-417$. 
da polis perfeita, mas pelo movimento celeste e pela harmonia do melhor dos mundos possíveis, cuja tessitura do fio da vida, administrado pelas Parcas, jamais é cortado, posto que a fiação poética ininterrupta permite uma duração que se renova com banquetes a cada celebração do Ano Novo na idade de ouro moderna.

Semelhante à supressão simbólica da morte no almanaque francês, observa-se a temática da finitude, no Almanaque Brasileiro Garnier para o ano de 1907, travestida de uma pompa funérea substituidora do Feio, do perecível, como resgate da beleza da vida pela tabelação dos preços dos caixões e dos serviços para sepulto, do mais suntuoso ao mais singelo, como recuperação do Belo em meio ao luto oriundo da perda do ente amado, uma espécie de alento para a dor por meio da arte de bem morrer. É a estetização da morte que permite a reconquista da beleza perdida, como se tal ritual apagasse o tom lúgubre de tal momento e reavesse simbolicamente o que se esvaiu com o decurso, a fim de perdurar, em decorrência de sua inserção no microcosmo místico-poético, no eterno renascimento.

É também pela Paidéia Poética que os leitores brasileiros têm orientação para aquisição do método apaziguador dos desassossegos da alma decorrentes da certeza da finitude, os serviços da Empresa Funerária estabelecida em um dos salões da Santa Casa de Misericórdia, na praia de Sancta Luzia, cujo expediente para obtenção do aparato transformador do Feio em Belo inicia às 9 horas da manhã e finda às 5 horas da tarde, todos os dias, ou seja, periodicidade condizente com o inesperado ceifar do fenecimento, ainda que o horário respeite a dinâmica do mundo dos viventes. A pedagogia para o bom perecimento perdura na instrução concernente à pessoa solicitadora dos serviços funerários, que deve estar munida do atestado de óbito passado pelo médico e se dirigir à pretoria respectiva, onde obterá a certidão necessária para ir, então, ao escritório da empresa. Tendo seguido tal orientação, mediante prévio pagamento (ou fiança de pessoa conhecida), incumbem-se do fornecimento de tudo, passando a ideia de que o contratador não terá qualquer tipo de preocupação em tal momento pesaroso, pelos valores fixados nas tabelas, o que reforça o caráter de amenização da dor por 


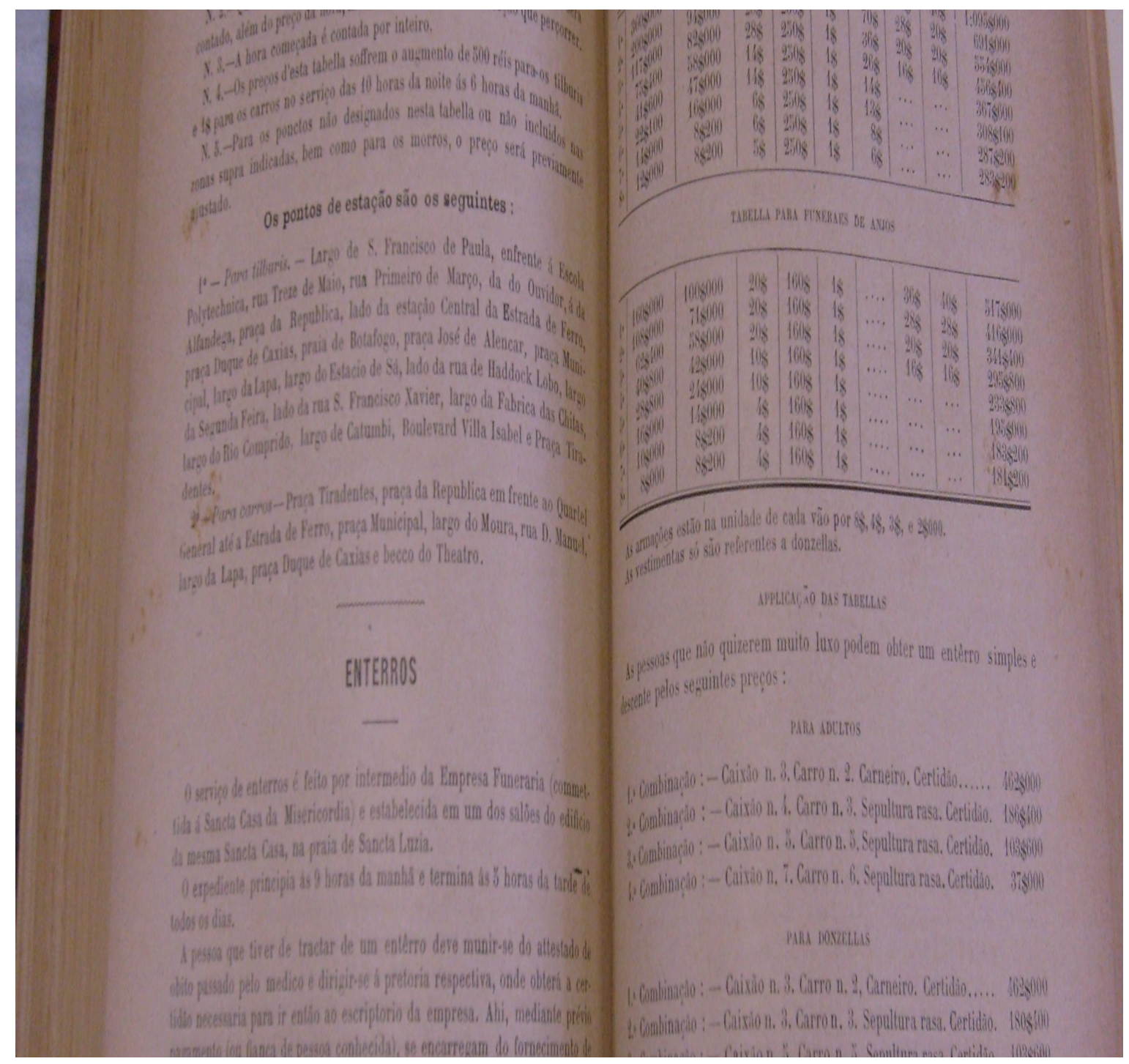

uma espécie de distanciamento do individuo em relação à realidade tétrica, para que o Feio, sem vida, vestido com a roupagem embelezadora, possa ser velado em meio aos vivos, corrigindo o funéreo com uma estética apagadora dos traços da morte, para recobrar o viço perdido na condição de falecido. A didática para aquisição da bela morte ainda informa a respeito das pessoas que pertencem a alguma das corporações religiosas que possuem cemitério privativo, sendo mister que o encarregado do enterro dirija-se (munido do diploma ou do documento comprobatório) à secretaria da respectiva ordem, sítio em que receberá a guia para o cemitério.

A partir da orientação, quanto a logradouro e práticas a ser consideradas para contratação dos serviços funerários, a educação para a morte perdura nas tabelas dos preços determinados para cada item do aparato concernente ao funeral, a primeira correspondente a 
adultos e a donzelas, com uma divisão de classes, da primeira a oitava, uma espécie de hierarquização dos valores para obtenção do mais oneroso ao mais modesto, sinônimo de melhor ou pior estetização do Feio, do caixão que segue o princípio gradativo das tarifas, do dispendioso ao módico, símbolo da couraça que reveste a funitude com ares de suntuosidade, do veículo condutor do morto à sepultura, que se infere o cotejo com o deus Caronte - haja vista a recuperação do Tempo Sagrado no microcosmo místico-poético de almanaque - que segundo Commelin, era responsável por transportar além do Estige e do Aqueronte as sombras dos mortos numa barca estreita, precária e de cor lúgubre. Além de idoso, era avaro, pois só levava em sua condução as sombras dos que tinham sepultura e que lhe pagavam a passagem. O barqueiro do Inferno é pintado como um velhote magro, alto e forte; de olhos vivazes, rosto esplêndido, apesar de austero, possui uma marca divina, ainda apresenta uma barba branca, comprida e densa, sua vestimenta é de uma cor escura e manchada pelo limo preto dos rios infernais, está geralmente de pé em sua barca e segura o remo com as duas mãos ${ }^{107}$. Ora, o diálogo com a miticidade dos antigos é atualizada na modernidade com os veículos, transportadores dos mortos, a motor, dos mais luxuosos aos mais singelos, e polidos com cera brilhosa, sem as manchas da lama preta dos rios infernais, além de ter o seu condutor embelezado em sua aparência e com vestuária apropriada, o que corrobora a estetização da finitude, aformoseando-a de tal maneira, que a beleza da vida já parece recuperada. $\mathrm{O}$ além-túmulo é ainda adornado pelos itens da tabela, com seus respectivos valores, sepultura rasa e carneiro, ou gaveta, onde geralmente a suntuosidade ou a singeleza podem ser percebidas no embelezamento do jazigo, também pela certidão de óbito, uma identificação que ainda nutre simbolicamente a condição de existência e não de indigência do morto, o que ainda permite a ilusão de sua permanência no mundo dos viventes. $\mathrm{O}$ componente subsequente é a vestimenta, que tem poder para ornar o corpo inerte, o Feio, reavendo a beleza perdida pelo fenecimento, dando a impressão de uma bela morte, o que subistitui o aspecto macabro pela estetização da realidade funérea, complementada pelo embelezamento do altar e da essa, estrado onde se coloca o cadáver, com seus adornos que desviam a atenção do contexto mortuário, pela contemplação do Belo, inscrito na arte de bem morrer. É importante destacar que tanto o altar quanto a essa não são contemplados pelos valores a partir da quinta classe, o que nas cidades excelentes, tanto Paris - já elucidada como sítio onde todos podem portar a mesma vestimenta indicada para o ritual do crepe - quanto Rio de Janeiro, é possível por todos em decorrência da equidade entre seus habitantes, sem a 107. Commelin, pp. $192-193$. 
privação de nenhuma classe ao acesso à estética apagadora do sombrio, posto que o perecer segue o mesmo viés para todos, após uma vida longeva oriunda dos efeitos de seus tantos elixires, para renascimento ad infinitum, pelo fazer poético incessante, no melhor dos mundos possíveis.

A segunda tabela constitui os preços dos serviços funerários dos anjos, vocábulo que por si mesmo simboliza a atenuação da perda na mais tenra idade, dando-lhe ares de sacralidade e a ideia de retorno ao lugar de onde saíra a pouco, que seguem os mesmos itens da supracitada, seguindo a mesma gradação de valores, mas que difere no campo da vestimenta, que é fornecida apenas às donzelas.

Considerando as duas tabelas, a Paidéia Poética ainda informa os leitores a respeito de sua aplicação, a pessoas que não fazem questão de suntuosidade na contratação dos serviços funerários, que podem obter um enterro simples e digno pelos preços apontados, com quatro combinações para adultos, os caixões associados aos carros, aos carneiros e à certidão, ou os esquifes acompanhados dos veículos, da sepultura rasa e da certidão, que seguem a mesma hierarquia tarifária; e outras quatro para donzelas, que reproduzem as mesmas combinações dos intens mencionados, exceto o caixão e o valor total do segundo agrupamento. A pedagogia para a bela morte ainda acrescenta uma observação, que os caixões para adultos e donzelas de números 1 e 2 que tenham mais do que 60 polegadas pagarão a diferença caso excedam a medida determinada, de $6.000 \$$ para o primeiro e de $3.000 \$$ para o segundo.

Por meio da estetização da morte, para amenização da dor da perda, observa-se que todo o aparato concernente aos serviços funerários e os períodos de luto adornados de uma bela roupagem buscam, de alguma maneira, recuperar simbolicamente o que findou em decorrência da passagem do decurso, o que é verdadeiramente recobrado nas Repúblicas das delícias, Paris e Rio de Janeiro, que já não seguem o Tempo Profano, mas tecem de forma infinda o Tempo Sagrado regenerador, pela Poiésis, de tudo o que se esvaiu, como um eterno renascimento do Belo nas cidades excelentes, além de não utilizar nada de tal embelezamento moderno, posto que no melhor dos mundos possíveis as pessoas morrem como que tomadas por sono, com a certeza do retorno simbólico ininterrupto, sem as penas e os pesares da modernidade. $\mathrm{O}$ aformoseamento da imagem da finitude de lúgubre para bela, a fim de ser contemplada em toda a sua pompa fúnebre, remete ao deus Tânatos ou Morte, nome masculino grego - posto que ao se recobrar o Tempo Sagrado no microcosmo místico-poético de almanaque, retoma-se o princípio do mundo, com suas deidades e seus heróis, - que segundo Commelin, é filho da Noite, que o gerou sem auxílio de nunhuma outra deidade, 
irmão do Sono (Hipnos) e inimigo impiedoso do gênero humano, abominável inclusive aos Imortais, instalou morada no Tártaro, conforme Hesíodo, ou diante da porta do Inferno, de acordo com outros poetas. Nesses sítios Hércules acorrentou-o com cadeias de diamante, no momento em que foi libertar Alceste. O nome do deus Tânatos era raramente pronunciado na Grécia, visto que a superstição receava, dessa forma, despertar uma ideia exasperada, ao trazer ao espírito, a imagem do perecimento. A divindade tinha um coração de ferro e entranhas de bronze, que os gregos representavam na figura de um menino preto com pés tortos e acariciado pela sua mãe, Noite. Tal característica, algumas vezes, aparece apenas por meio dos pés cruzados, indicação do incômodo que os corpos encontram na sombra. Era ainda simbolizada nas esculturas antigas com um rosto deformado e emagrecido, os olhos cerrados, coberta por um véu e portadora, como o Tempo, de uma foice na mão, cujo atributo parece significar que os homens são ceifados em abundância, como as flores e as ervas temporárias, pintada ainda, na maioria das vezes, como um esqueleto. A deidade também é caracterizada por uma urna e uma borboleta, a primeira contendo cinzas, ao passo que a segunda alçando vôo que simboliza a esperança de outra vida ${ }^{108}$.

Considerando as tabelas de valoração dos serviços funerais para bem morrer e do quadro de períodos de luto também para apreender a arte do bom fenecimento, que se nota uma espécie de atualização do não pronunciamento, pelos gregos, do vocábulo "morte”, como sinônimo de mau agouro, por meio da recusa de mostrá-la em sua condição funérea, representativa do Feio, mas vestida com uma rupagem que lhe apaga a caracterização que se faz desde os antigos, não mais com o rosto deformado e emagrecido, mas estetizada pela mimesis da beleza que esvaiu, por meio de todo um aparato que recobra o Belo incrito na natureza humana e ainda pelo vestuário que aformoseia o pós-fenecimento, ao adornar a lembrança que antes macabra, torna-se uma etiqueta ou moda mortuária que permite o apagamento de sua imagem tétrica. Ora, em tais campos de lisibilidade, a deidade não é simbolizada com a foice nas mãos ou como um esqueleto, mas sim como o vôo da borboleta que simboliza a esperança de outra vida, o que permite fazer um cotejo com a imortalidade da alma platônica que, por sua vez, é representada no microcosmo místico-poético pelo incessante renascimento do Belo, engendrado pela Poiésis, a cada feitura de almanaque. Desse modo, a partir da representação da morte pela urna portadora das cinzas, infere-se o diálogo com o Mito de Pandora - haja vista a retomada do Tempo Sagrado no microcosmo místico-poético de tais livros herméticos - com sua caixa armazenadora dos males da $108 \quad$. Commelin, pp. 198, 199 e 200. 
humanidade, mas que jamais é aberta comprometendo a excelência da idade de ouro de almanaque, ao contrário, pela Paidéia Poética, a irrupção das problemáticas da modernidade é contida, e a vida de labor e de dificuldades transformada em eterno gozo nas Repúblicas das delícias, Paris e Rio de Janeiro.

É pela fiação ininterrupta do Tempo Sagrado, pela Poiésis, que o decurso nas polis harmônicas já não é inexorável, mas eterno regenerador do que se esvaiu, o que permite aos leitores uma vida sem infortúnios ou preocupações de qualquer ordem, inscrita na idade de ouro moderna que transforma a voracidade insaciável de Cronos pelos dias, em uma poeticidade resgatadora do Belo a cada feitura da nova realidade. A nova Criação é a própria ordenação da massa caótica das cidades grandes, Paris e Rio de Janeiro, em uma mimeses infindável recuperadora da verdadeira beleza do mundo suprimida pelas mazelas da modernidade, cuja excelência recobrada traduz o Sublime não apenas das urbes ideais, mas da totalidade do melhor dos mundos possíveis. 


\section{Considerações Finais}

Após percorrer as deleitáveis sessões de almanaque para análise da edificação das cidades ideais, Paris e Rio de Janeiro, tanto no Almanach Hachette quanto no Almanaque Brasileiro Garnier, afere-se que a partir de tal feitura anual todos os outros capítulos são fiados, como metáfora da tessitua infindável do grande tecido de Penélope, representativo do fazer e do desfazer o tempo anualmente, ou melhor, recriá-lo ad infinitum para abrigo, não dos possíveis substituidores de Ulisses, mas dos males modernos, para alcance do Sublime em tais sítios de excelência. É, pois, nas Repúblicas das delícias do melhor dos mundos possíveis, que o flâneur-poeta cria, pelo ato poético, um microcosmo ideal para seus leitores, sítio, portador de prognósticos e de receitas de felicidade, que simboliza o universo místico embebido de poeticidade da verdadeira idade de ouro atualizada.

Para tanto, o flâneur-poeta apresenta um caleidoscópio poético de temáticas utópicas que sustenta a edificação das urbes dos sonhos, sendo possível, por meio das infindáveis leituras de seus almanaques, encontrar receitas para toda e qualquer problemática humana. É em tal briqueabraque, como atualização do comércio de novidades dos antigos colporteursmascates, que a hôtte é aberta simbolicamente a cada início de ano e diariamente, o que representa a magia terapêutica que desobstrui a retina impedida de enxegar a verdadeira beleza do mundo. Logo, os leitores possuem, simbolicamente, recomendações para adquirir a tão sonhada eterna juventude ou o alcance do belo que não se esvai com o descurso, com os diversos elixires, remédios e orientações de cunho medicinal, a fim de construir um corpo perfeito e livre das marcas certeiras da passagem inexorável do tempo. Tais receitas caminham junto ao projeto de eliminação do Feio, inscrito no físico e no espírito dos habitantes, como reflexo das problemáticas da modernidade, fazendo do resgate do Belo o caminho para alcançar uma vida excelente, seja no Pays de Cocagne, seja no País de São Saruê da Terra sem Males de almanaque, mitos que nutrem o imaginário coletivo francês e brasileiro. 
É a mimesis do mundo moderno, como estetização do Caos para resgate do Belo, que permite a perfeição tantos dos leitores/habitantes como do microcosmo curado de suas mazelas, o que se increve no canto regenerador e enaltecedor dos prodígios dos povos que constituem o melhor dos mundos possíveis, uma espécie de metáfora epopéica de almanaquias, cujos deuses e heróis misturam-se entre os entes comuns, ou melhor, transformam-os em robustos combatentes das intempéries cotidianas, já vencedores pela proteção do manto ou da leitura mítico-poética de todos os dias. A estetização da realidade enferma, metamosfoseada em epopéia para eterno louvor do canto popular, faz do grotesco ou dos males circundantes, sanados e revelados pela Paidéia Poética, uma catarse de almanaque curativa dos desassossegos da alma dos leitores, uma purgação das paixões pelo eterno riso das anedotas periódicas delatoras da falsa aparência inscrita na modernidade que, por sua vez, é purificada para conquista do Sublime em tal sítio maravilhoso. É na gargalhada cotidiana, no ficar à-toa, no dançar, na eterna alegria do microcosmo místico-poético, que se tem a comédia ou a imitação do Feio para deleite infindável, a própria arte de bem viver ministrada nas páginas de almanaque, que remete à consideração de Vitor Hugo a respeito da separação entre o belo e o grotesco:

(...) (um não exclui o outro) pretendem que o disforme, o feio, o grotesco nunca deve ser objeto de imitação para a arte; respondese-lhes que o grotesco é a comédia, e que, aparentemente, a comédia faz parte da arte. Tartufo não é belo, Pourceaugnac não é nobre; Pourceaugnac e Tartufo são admiráveis jatos da arte. (Hugo, p.43, 1988)

É por meio da mimesis do grotesco que se alcança o Belo nas cidades ideais, traduzido na verdade revelada pelo inolvidável passado de geração a geração, na saída da caverna moderna pela feitura poética, para que a nova Criação de almanaque, com a proteção dos santos, dos astros, dos signos e de homens dotados de poderes sobrenaturais, simbolize a excelência do princípio do mundo, que faz dos sítios harmônicos, engendrados anualmente a partir da massa caótica da modernidade, o microcosmo sagrado e perfeito, onde até mesmo o decurso é domado em seus vários calendários, para alcance do Tempo Sagrado representante do próprio Sublime. 


\section{Referências Bibliográficas}

ADORNO, Theodor W. As estrelas descem à Terra: a coluna de astrologia do Los Angeles Times: um estudo sobre supestição secundária; tradução Pedro Rocha de Oliveira. - São Paulo: Editora Unesp, 2008.

ANDRIES, Lise. La Bibliothèque blue au dix-huitième siècle.Une tradition éditoriale. Oxford: Voltaire Foundation, 1989.

; BOLLÉME, Geneviève; BRICOURT, B. Burke, P, e. a.. La Bibliothèque bleu nel Seicento o della letteratuura per il popolo.- Bari: Adriaca; Paris: Nizet, 1988.

Paris: Imago, 1994.

Le grand livre des secrets: le colportage en France aux 17e et 18 e siècles.

La Bibliothèque bleu et les littératures de colportage [colloque, Troys, 12-

13 novembre 1999]/ éd.par Thierry Delcourt et Élisabeth Parinet. Paris: École des chartes; Troyes: la Maison du Boulanger, 2000.

-------------. Colportage et lecture populaire: imprimés de large circulation en Europe, XVIe-XIXe siècles [colloque, Wolfenbüttel, 21-24 avril 1991]/ sous la dir. de Roger Chartier et Hans-Jürgen Lüsebrink. Paris: IMEC éd. ; Éd. de la Maison des sciences de l'homme, 1996.

ANÔNIMO. Le grand kalendrier des bergèrs. Editado em Paris1499.

BAKHTINE, Mikhaïl. Esthétique et théorie du Roman; traduit du russe par Daria Olivier. Paris: Gallimard, 1978.

BENJAMIN, Walter. Paris Capital du XIX siècle le livre des passages. Paris: Édition du Cerf, 1989.

Charles Baudelaire um lírico no auge do capitalismo; tradução José

Martins Barbosa, Hemerson Alves Baptista. - 1. Ed. - São Paulo: Brasiliense, 1989.

BOLLÉME, Geneviève. La Bibliothèque bleu. Paris: Julliard, 1971(archives).

Le peuple par écrit. Paris: Éditions du Seuil, 1986. 
Flammarion, 1975.

La bible bleu. Antolhogie d'une littérature populaire. Paris:

----------------. Les almanachs populaires aux XVII et XVIII siècles. Essai d'histoire sociale. Paris: La Haye Mouton, 1969.

La littérature populaire et de colportage, dans livre et société dans la

France du XVIII siècle. Paris: La Haye Mouton, 1965.

BOSI, Alfredo. O ser e o tempo da poesia. São Paulo: Cultrix, 1977.

Reflexões sobre a arte. São Paulo: Ática, 1986.

BOURDIEU, Pierre. O Poder Simbólico. Rio de Janeiro: Bertrand Brasil, 1998.

A Economia das Trocas Linguísticas: O que Falar Quer Dizer. São

Paulo: Editora da Universidade de São Paulo, 1998.

BRETON, Davi. Anthropologie du corps et modernité. Paris: Quadrigue, 2008.

CAILLOIS, Roger. Le Mythe et l'homme. Paris: Gallimard, 2002.

CANTEL, Raymond. Les prophéties dans la littérature populaire du Nordeste. Caravelle;

Cahiers du Monde Hispanique et Luso-Brésilien, Toulouse, Univ. de Toulouse, n. 15, 1970.

CARLOS, R; ANA Cristina M. Lopes. Dicionário de Teoria da Narrativa. São Paulo: Editora Ática, 1988.

CARNEIRO, Henrique. Filtros, Mezinhas e Triacas. São Paulo: Editora Xamã, 1994.

CASCUDO, Luís da Câmara. Superstição no Brasil. São Paulo: Global, 2002.

CHALHOUB, Sidney. Cidade Febril Cortiços e Epidemias na corte Imperial. São Paulo: Companhia das Letras, 1996.

CHEVALIER \& GHEERBRANT. Dicionário de símbolos: (mitos, sonhos, costumes, gestos, formas, figuras, números). São Paulo: José Olympio, 1906.

Dictionnaire des Symboles. Paris: Robert Laffont/Jupiter,

1982.

CITELLI, Adilson. Linguagem e Persuasão. São Paulo: Editora Ática, 1991.

COMMELIN, P. Mitologia grega e romana; tradução Eduardo Brandão. - 2. ed. - São Paulo: Martins Fontes, 1997.

DARNTON, Robert. Édition et sédition: l'univers de la littérature clandestine au XVIIIe siècle. Paris: Gallimard,1991.

DARMON, Pierre. Médicos e assassinos na Belle Époque. Rio de Janeiro: Paz e Terra, 1991. ELIADE, Mircea. Mythes, rêves et mystères. Paris: Gallimard, 1957. (Nrf "Les Essais", 84). 
Mito do eterno retorno; tradução José A. Ceschin. - São Paulo: Mercuryo, 1992.

Mito e Realidade. São Paulo: Perspectiva, 2004.

FERREIRA, Jerusa Pires. Heterônimos e cultura das bordas: Rubens Lucchetti. Revista USP,

São Paulo, n. 4, p. 169-174, dez. 1989/ jan.- fev. 1990.

GIOVANNI, Geraldo. A Questão dos Remédios no Brasil (produção e consumo). São Paulo: Polis, 1980.

HESÍODO. Os trabalhadores e os dias; tradução, introdução e comentários Mary de Camargo Neves Lafer - 4. ed. - São Paulo: Iluminuras, 2002.

. Teogonia a origem dos deuses; estudo e tradução Jaa Torrano - 5. ed. - São Paulo: Iluminuras, 2003.

Hugo, Victor. Do grotesco e do sublime; tradução do "prefácio de Cromell". São Paulo: Perspectiva, 1988.

JAEGER, Werner Wilhelm. Paidéia: a formação do homem grego; [tradução Artur M. Parreira; adaptação para a edição brasileira Monica Stahel: revisão do texto grego Gilson Cesar Cardoso de Souza]. 3. ed. - São Paulo: Martins Fontes, 1994.

LEBATE, Beatriz Caiuby. Drogas e cultura: novas perspectivas. Salvador: EDUFBA, 2008.

LESSA, Orígenes. Nota introdutória. In: Fundação Casa de Rui Barbosa. O cordel e os desmantelos do mundo. Rio de Janeiro, 1983.

LEWINSOHN, Rachel. Três Epidemias Lições do Passado. Campinas, SP: Editora da Unicamp, 2003.

MANDROU, Robert. De la culture populaire aux 17e et 18e siècles. Paris: Imago, 1985.

MANNHEIM, Karl. Ideologia e Utopia. Rio de Janeiro: Guanabara, 1986.

MAUSS, Marcel. Sociologie et Anthropologie. Paris: Presses Universitaires de France, 1950.

MEYER, Marlyse. (org.). Do almanak aos almanaques. São Paulo: Ateliê Editorial, 2001.

MOLLIER, Jean-Yves. Le camelor et la rue Politique et démocratie au tournant des XIX et XX siècles. Paris: Fayard, 2004.

Louis Hachette (1800 - 1864) Le fondateur d'um empire. Paris:

Fayard, 1999.

MONTERO, Paula. Magia e Pensamento Mágico. São Paulo: Editora Ática, 1986.

NEEDELL, Jeffrey D. . Belle Époque Tropical. São Paulo: Companhia das Letras, 1993.

NISARD, Charles. Histoire des Livres Populaires ou de la Littérature du Colportage. Paris: G.- P. Maisonneuve \& Larose Éditeurs, 1989. 
NUNES, Benedito. Passagem para o Poético [Filosofia e poesia em Heidegger]. São Paulo: Editora Ática: 1992. . Introdução à Filosofia da Arte. São Paulo: Editora Ática, 1989.

OLIVEIRA, Elda Rizzo de. O que é benzeção. São Paulo: Editora Brasiliense, 1985. . O que é medicina popular. São Paulo: Abril Cultural: Brasiliense, 1985.

PAQUOT, Thierry. A Utopia. Rio de Janeiro: DIFEL, 1999.

PIGNARRE, Philippe. Qu'est-ce qu'un medicament?. Paris: La Découverte, 1997.

PLATON. Ion. Paris: Flammarion:1989.

A República: [ou Sobre a justiça, diálogo político]; tradução Anna Lia Amaral de Almeida Prado; revisão técnica Roberto Bolzani Filho. - São Paulo: Martins Fontes, 2006.

. O banquete, ou, do amor; tradução, introdução e notas do Prof. J. Cavalcanti de Souza. - 5. ed. - Rio de Janeiro:Difel, 2008.

PONTE, Sebastião Rogério. Fortaleza Belle Époque: reforma urbana e controle social 1860 1930 / Sebastião Rogério Ponte. 4. ed. - Fortaleza: Edições Demócrito Rocha, 2010.

QUEIROZ, Renato da Silva. O Corpo Brasileiro Estudos de Estética e Beleza. São Paulo: Editora Senac, 2000.

RADICH, M. C. Almanaque: tempo e saberes. Lisboa, Centelha, s.d.

RAGO, Margareth. Do Cabaré ao Lar A Utopia da Cidade Disciplinar Brasil 1890-1930. Rio de Janeiro:Paz e Terra, 1985.

REZENDE, Vani T. de. Luzes e estrelas: T. W. Adorno e a astrologia - um estudo sobre a obra The stars down to earth de T. W. Adorno. São Paulo: Associação Editorial Humanitas, 2006.

RODRIGUES, José Carlos. Tabu do Corpo. Rio de Janeiro: Dois Pontos, 1986.

ROGUE, Christophe. Compreender Platão; - 5. ed. - tradução Jaime A. Clasen. - Petrópolis, Rj: Vozes, 2011.

SANSOT, Pierre. Poétique de la Ville. Paris: Méridiens Klincksieck, 1994.

SANTIAGO, Jorge P. Rio et la ville clandestine Anthropologie et littérature de Lima Barreto /Tome 1. Paris: Editions Le Manuscrit, 2009.

SAUSSURE, Ferdinand de . Curso de Linguística Geral. São Paulo: Editora Cultrix, 9 edição. SCLIAR, Moacyr. Do Mágico ao Social Trajetória da Saúde Pública. São Paulo: Editora SENAC, 2002.

SERVIER, Jean. Histoire de l'utopie. Paris: Éditions Gallimard, 1967. 
SEVCENKO, Nicolau. A Revolta da Vacina. São Paulo: Editora Scipione, 1993.

SILVA, Maurício. A Hélade e o Subúrbio Confrontos Literários na Belle Époque Carioca.

São Paulo: Edusp, 2006.

SITE: http://www.fapunifesp.edu.br

STIERLE, Karlheinz. La capitale des signes Paris et son discours. Paris: Éditions de la Maison des Sciences de l'homme, 2001.

SUDO, N; LUZ, M. T. O Corpo e a Medicina Social no Brasil Revista Cátedra de Gênero Publicações. Rio Grande do Sul: 2007. p.1 a 13. Disponível em:

THOMAS, Rosalind. Letramento e oralidade na Grécia Antiga; trad. Raul Fiker. São Paulo: Odysseus Editora, 2005.

TORRES, Ulisses Lemos. A Estética na Medicina. São Paulo: Milesi Editora LTDA, 1979.

VELloso, Mônica Pimenta. As Tradições Populares na Belle Époque Carioca. Rio de Janeiro: FUNARTE/Instituto Nacional do Folclore, 1988.

VENÂNCIO, Henrique Carneiro. Álcool e drogas na história do Brasil. São Paulo: Alameda; Belo Horizonte: Editora PUCMinas, 2005.

Filtros Mezinhas e Triacas. São Paulo: Xamã, 1994.

VIGARELLO, Georges. História da Beleza, tradução Léo Schlafman- Rio de Janeiro. Rio de Janeiro: Ediouro, 2006.

VILHENA, Luís Rodolfo. O Mundo da Astrologia estudo antropológico. Rio de Janeiro: Jorge Zahar Editor Ltda, 1990.

WHITROW, G. J. O Tempo na História. Rio de Janeiro: Jorge Zahar, 1993.

WINOCK, Michel. La Belle Époque. Paris: Éditions Perrin, 2007.

WITKOWSKI, Claude. Bibliothèque bleu, 1859-1870. Baumont: C. Witkowski, 1984.

ZUMTHOR, Paul. Introduction à la poésie orale. Paris: Éditions du Seuil, 1983.

-----------------. A letra e a voz: A “literatura” medieval / Paul Zumthor; tradução Amalio Pinheiro, Jerusa Pires Ferreira - São Paulo: Companhia das Letras, 1993. 